\title{
O PATRIMÔNIO HISTÓRICO ARQUEOLÓGICO DE SERRA DA MESA: A Construção de Uma Nova Paisagem
}

Tese de Doutoramento apresentada ao curso de Pós-Graduação do Departamento de Geografia da Faculdade de Filosofia, Letras e Ciências Humanas da Universidade de São Paulo, sob a orientação do Prof. Dr. JOSÉ WILLIAM VESENTINI.

São Paulo 
Este trabalho é dedicado aos meus pais João Inácio, Divina (in memoriam): dois trabalhadores rurais sem- terra, analfabetos, que, mesmo com uma prole muito numerosa, puderam me ensinar valores e conhecimentos que não se encontram em nenhuma tese, mas que me possibilitaram chegar até aqui. A eles, o meu sincero muito obrigada. 


\section{AGRADECIMENTOS}

Este trabalho é o resultado de um longo processo, e, como tal, diversas foram as etapas a serem vencidas. Em cada uma delas contamos com a colaboração de diversas pessoas e instituições, e, mesmo correndo o risco de esquecermos alguns nomes, expressamos aqui o nosso agradecimento a todos, que em qualquer instância nos auxiliaram, e em especial:

- ao Prof. Dr. José William Vesentini, nosso orientador, que acompanhou com paciência e boa vontade o desenvolvimento deste trabalho, e, a despeito de nossas próprias dificuldades, foi capaz de nos auxiliar de maneira eficiente e profissional, contribuindo para o nosso crescimento;

- à CAPES, pelo auxílio financeiro que possibilitou nossa dedicação e o empenho de muitas horas de trabalho nesta pesquisa;

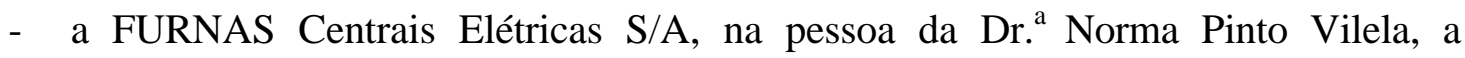
gentileza em ceder o material necessário e de extrema importância para o desenvolvimento deste trabalho;

- ao Prof. Dr. Carlos Magno Guimarães, coordenador do Projeto de Salvamento Histórico Arqueológico na Área Atingida Pela Represa de Serra da Mesa - Goiás, Convênio FURNAS/UFMG, pela sua disponibilidade, boa vontade e competência; pelas sugestões, discussões, incentivo e amizade;

- ao Setor de Pós-Graduação da Universidade de São Paulo e aos seus funcionários, que pacientemente nos auxiliou em todas as nossas dúvidas e dificuldades quanto ao processo administrativo;

- à professora Lúcia Maria Lima, por ter conseguido tempo, em meio a tantas tarefas, para fazer a revisão dos originais; 
- à Eliane Marinalva de Souza, pela amizade, carinho e dedicação na revisão bibliográfica;

- aos companheiros de trabalho, que, como eu, passaram preciosos dias no interior de Goiás, buscando aprender e conhecer um pouco mais sobre a nossa história comum;

- aos meus familiares, principalmente meus filhos Ana Clara e Daniel, que, apesar de muito pequenos, se viram privados por sucessivas horas do nosso convívio familiar, para que pudéssemos dar andamento ao nosso trabalho;

- ao Célio, que, com imensa dedicação e paciência, esteve sempre ao nosso lado, nos incentivando e compreendendo nossas dificuldades diárias;

- e sobretudo a Deus, porque sem o Seu auxílio, nada teria sido possível. 


\section{SUMÁRIO}

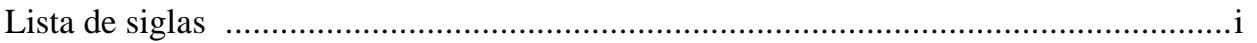

Lista de quadros ......................................................................................... iv

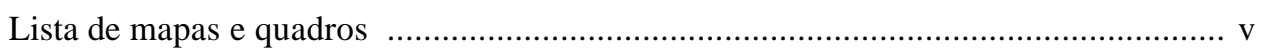

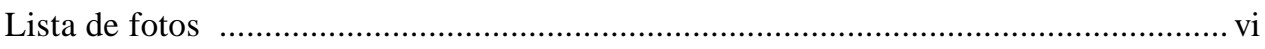

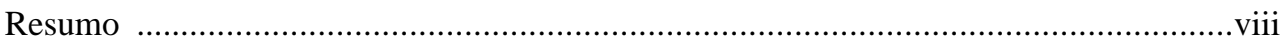

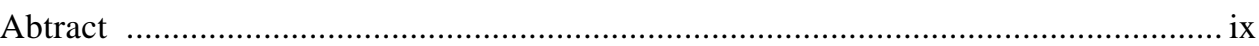

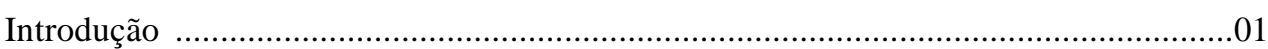

1. A área do empreendimento e seus objetivos ............................................... 12

2. Histórico do projeto da Usina Hidrelétrica de Serra da Mesa .................... 16

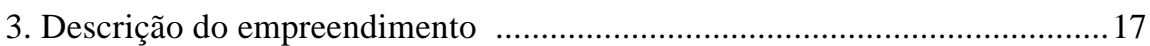

\section{CAPÍTULO I:}

Patrimônio Cultural: Compromisso com o Futuro ………………………………....2 20

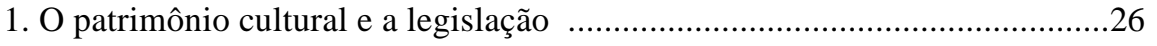

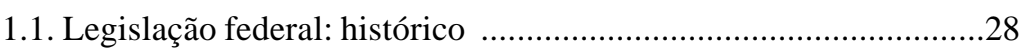

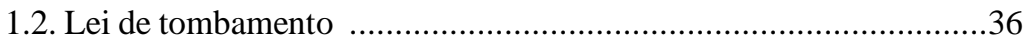

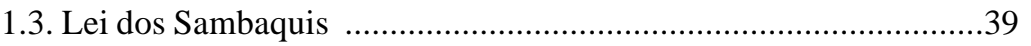

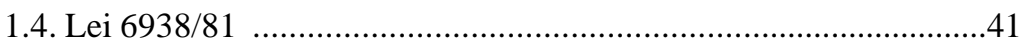

1.5 Lei CONAMA e Lei 95733/88 ……………………………......

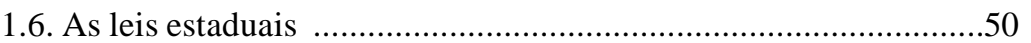

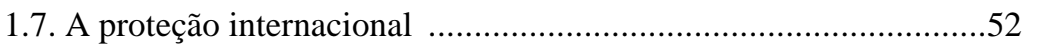

2. o patrimônio cultural histórico e pré-histórico .................................................61

3. A impoertância do patrimônio cultural para a construção da identidade ..... 73

\section{CAPÍTULO II:}

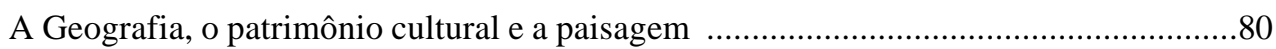

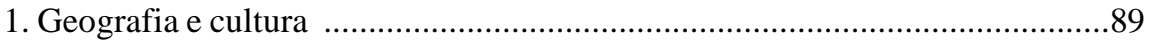

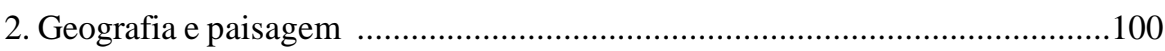

3. A paisagem como elemento cultural: a área de Serra da Mesa e suas características paisagísticas e culturais ..................................................107

3.1. A área do empreendimento: características gerais ........................111

3.2. A construção da paisagem e da cultura em Goiás ....................... 123 


\section{CAPÍTULO III:}

Serra da Mesa: a construção de uma nova paisagem ……………………………........131

1. O empreendimento de Serra da Mesa e suas justificativas .............................133

2. O patrimônio cultural (resgatado ou perdido) de Serra da Mesa ....................148

2.1. Fazendas ...................................................................................153

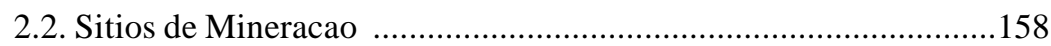

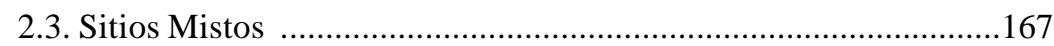

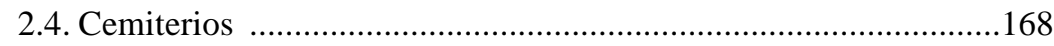

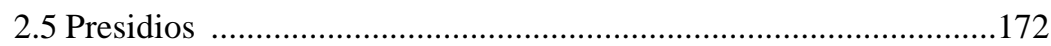

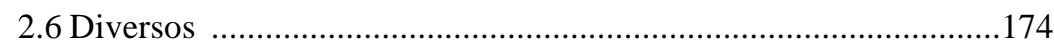

2.7 Nucleos Urbanos .......................................................................177

3. O empreendimento de Serra da Mesa valeu a pena Para quem ....................185

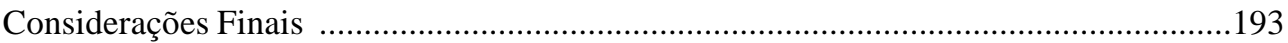

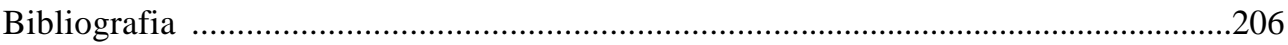

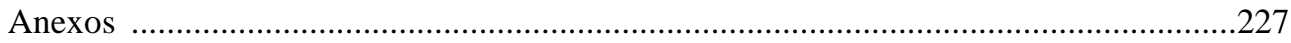




\section{LISTA DE SIGLAS}

AHE - Aproveitamento Hidrelétrico

AID - Área de Influência Direta

AII - Área de Influência Indireta

AMUNORTE - Associação dos Municípios do Norte de Goiás

BNDES - Banco Nacional de Desenvolvimento Econômico e Social

BYU - Brigham Young University

CBGB - Comitê Brasisleiro de Grandes Barragens

CELG - Centrais Elétricas de Goiás

CENARGEN - Centro Nacional de Pesquisa de Recursos Genéticos e Biotecnologia

CNEC - Consórcio Nacional de Engenheiros Consultores

CODEMIN - Empresa de Desenvolvimento de Recursos Minerais

CONAMA - Conselho Nacional do Meio Ambiente

COTREL - Cooperativa Tritícula de Erexim Ltda.

DER/GO - Departamento de Estradas de Rodagem do Estado de Goiás

DGST - Departamento de Construção e Geração de Serra da Mesa

DNAEE - Departamento Nacional de Águas e Energia Elétrica

DNER - Departamento Nacional de Estradas de Rodagem

DNPM - Departamento Nacional de Produção Mineral

DPHAN - Diretoria do Patrimônio Histórico e Artístico Nacional

EIA - Estudo de Impactos Ambientais

ELETROBRAS - Centrais Elétricas Brasileiras S. A.

ELETROSUL - Centrais Elétricas Sul do Brasil S.A.

EMBRAPA - Empresa Brasileira de Pesquisa Agropecuária

FEMAGO - Fundação Estadual do Meio Ambiente de Goiás

FIOCRUZ - Fundação Instituto Oswaldo Cruz

FMI - Fundo Monetário Internacional 
FNS - Fundação Nacional de Saúde

FUNAI - Fundação Nacional do Índio

FUNATURA - Fundação Pró-Natureza

GPS - Global Position Sistem

IBAMA - Instituto Brasileiro do Meio Ambiente e Recursos Naturais Renováveis

ICOMOS - Conselho Internacional de Monumentos e Sítios

IESA - Projetista Internacional de Engenharia S.A.

IPHAN - Instituto do Patrimônio Histórico e Artístico Nacional

LI - Licença de Instalação

LO - Licença de Operação

LP - Licença Prévia

MNRJ - Museu Nacional do Rio de Janeiro

MW - Mega Watts

NA - Nível d'Água

OEA - Organização do Estados Americanos

ONU - Organização das Nações Unidas

OSU - Ohio State University

PACTO - Programa Avá-Canoeiro do Tocantins

PBA - Projeto Básico Ambiental

PIB - Produto Interno Bruto

RIMA - Relatório de Impacto Ambiental

SAMA - Empresa S. A. de Mineração de Recursos Minerais

SANEAGO - Empresa de Saneamento de Goiás

SHU - Sítio Histórico Urbano

SISNAMA - Sistema Nacional de Meio Ambiente

SPHAN - Secretaria do Patrimônio Histórico e Artístico Nacional

UCG - Universidade Católica de Goiás

UERJ - Universidade do Estado do Rio de Janeiro 
UFGO - Universidade Federal de Goiás

UFMG - Universidade Federal de Minas Gerais

UFPA - Universidade Federal do Pará

UFRJ - Universidade Federal do Rio de Janeiro

UFRS - Universidade Federal do Rio Grande do Sul

UHE - Usina Hidrelétrica

UnB - Universidade de Brasília

UNESCO - Organização das Nações Unidas para a Educação, a Ciência e a Cultura USP - Universidade de São Paulo 


\section{LISTA DE QUADROS}

Quadro 01 - Municípios Atingidos pelo Reservatório de Serra da Mesa Área de Inundação p. 13

Quadro 02 - Principais Características do Projeto p. 19

Quadro 03 - Ações de Comunicação Social para o Enchimento do Reservatório do Aproveitamento Hidrelétrico - Serra da Mesa

p. 141

Quadro 04 - As Dez Maiores Represas em Volume Armazenado p. 185 


\section{LISTA DE FIGURAS}

Figura 01 - Mapa de Localização da Usina Hidrelétrica de Serra da Mesa p. 14

Figura 02 - Mapa de Localização da Represa de Serra da Mesa

p. 15

Figura 03 - Mapa: Nações Indígenas em Goiás no Século XVIII p. 115

Figura 04 - Gráfico: Área de Inundação: População de 5 Anos ou Mais Tempo de Estudo p. 140

Figura 05 - Croquis Topográficos da Área do Arraial de Santa Rita p.184 


\section{LISTA DE FOTOS}

Foto 01 - Degradação Ambiental: Área Garimpada com o Uso de Trator p. 44

Foto 02 - Degradação Ambiental: Área de Desmatamento Clandestino p. 45

Foto 03 - Degradação Ambiental: Desmatamento Clandestino Realizado com o Uso de Trator p. 46

Foto 04 - Degradação Ambiental: Queimada Após Desmatamento p. 46

Foto 05 - Depredação de Monumento Histórico-Arqueológico p. 47

Foto 06 - Vestígios de Engenho - Vista Geral p. 155

Foto 07 - Fornalha de Pedras - Vista Geral p. 155

Foto 08 - Vestígios de Curral - Vista Geral p. 156

Foto 09 - Vestígios de Habitação - Vista Parcial p. 156

Foto 10 - Vestígios de Habitação - Detalhe p. 157

Foto 11 - Vestígios de Mineração : Área Antiga de Sedimento Revirado p. 160

Foto 12 - Canal para Condução de Água - Vista Parcial p. 160

Foto 13 - Aterro para Mineração - Vista Parcial p. 161

Foto 14 - Sondagem em Aterro - Vista Lateral p. 162

Foto 15 - Vestígios de Barragem de Pedras no Córrego Santa Rita p. 164

Foto 16 - Cachoeira do Machadinho - Vista Geral p. 164

Foto 17 - Cachoeira do Machadinho-Detalhe p. 165

Foto 18 - Área de Rejeito de Mineração p. 165

Foto 19 - Curral de Taipa e Blocos Rochosos - Detalhe p. 169

Foto 20 - Muro de Pedras - Detalhe p. 169

Foto 21 - Vestígios de Cemitério p. 171

Foto 22 - Vestígios de Cemitério p. 171 
Foto 23 - Vestígios de Forno de Queimar Telhas - Detalhe p. 175

Foto 24 - Capela de Santa Rita - Vista Geral ....................................................... p. 180

Foto 25 - Chave da Capela de Santa Rita - Detalhe ................................................ p. 181

Foto 26 - Capela de Santa Rita - Vista Parcial ...................................................... p. 181

Foto 27 - Capela de Santa Rita - Vista Parcial ........................................................ p. 182

Foto 28 - Vestígios de Muro de Pedras ................................................................. p. 182

Foto 29 - Vestígios de Arruamentos e Muros ........................................................... p. 183

Foto 30 - Vestígios de Arruamentos e Muros .......................................................... p. 183 


\section{RESUMO}

No interior de Goiás foi erguida uma barragem no curso do rio Tocantins para viabilizar a construção da Usina Hidrelétrica de Serra da Mesa, cuja represa resultou em um lago de cerca de $1.780 \mathrm{~km}^{2}$.

A referida área abrange, parcialmente, oito municípios daquele estado, e compreende uma região cuja ocupação histórica legou importantes sítios arqueológicos que são hoje testemunhos do período colonial: a ocupação bandeirante, que apresenta importantes vestígios de áreas de mineração, a ocupação agropastoril e antigas vilas e lugarejos.

Por se tratar de uma região, na atualidade, pouco dinâmica do ponto de vista econômico, é também muito pouco conhecida a nível nacional. Dessa forma, o patrimônio histórico arqueológico que seria perdido com a formação do lago, passou por um processo de salvamento, cujo resgate foi possibilitado através de um convênio entre FURNAS Centrais Elétricas e a UFMG.

O salvamento histórico arqueológico procedeu-se durante três anos ininterruptos de pesquisa de campo, evidenciando um riquíssimo patrimônio cultural, que urge ser divulgado tanto a nível acadêmico quanto para a sociedade brasileira como um todo. 
On the countryside of Goias was built a barrier across the waterway of the Tocantins river in order to make feasible the construction of Serra da Mesa Hydroeletric Power Station, whose dam resulted on a lake around $1.780 \mathrm{~km}$ long.

The mentioned area covers, partly, eight towns fron that state, which are part of a region of historical occupation that represents important archaeological sites that are today testimonies of the colonial period: pioneers occupation which presents important evidences of mining and farming areas and old villages and towns.

Furthermore, it is a region nowadays that is not very dynamic according to economical aspects, and not very notable concerning to the whole the country. So that, the historical archaeological patrimony that would be lost with the lake formation, has passed by a process of rescue that was only possible due to an agreement between FURNAS Power Company and UFMG.

The historical archaeological rescue happened during a 3-year-non-stop field-work, in which an extremely rich cultural patrimony was found and that it utters to be published not only to reach academic levels but also the Brazilian society in general. 
INTRODUÇÃO 


\section{INTRODUÇÃO}

Poucos assuntos têm despertado tanto a atenção da mídia e da comunidade em geral quanto as questões referentes à preservação dos patrimônios ambientais e culturais. A preocupação com a qualidade de vida e com a preservação da nossa identidade cultural para as próximas gerações são, geralmente, assuntos de relevância, com ênfase, cada vez maior, nos mais diferenciados grupos sociais e instâncias do poder público.

Essa reflexão sobre o tema "Patrimônio Cultural" surgiu a partir da experiência da autora deste trabalho como pesquisadora num programa de recuperação do patrimônio Histórico Arqueológico desenvolvido pela Universidade Federal de Minas Gerais, em convênio com FURNAS Centrais Elétricas S.A., visando o levantamento e o salvamento de sítios arqueológicos na área que seria inundada pelo reservatório da Usina Hidrelétrica de Serra da Mesa, no interior de Goiás. 
Nesse programa, as pesquisas estiveram voltadas para as manifestações culturais posteriores ao ano de 1500, que marca o começo do período histórico no Brasil, com o início da colonização européia, já que essa é a divisão usualmente adotada pelos pesquisadores.

"Na América do Norte, os arqueólogos tratam de dois períodos históricos: pré-história e história. O período préhistórico, domínio de estudo de arqueólogos pré-historiadores, inicia-se com as mais antigas ocupações; aborígenes do continente, em cerca de 10.000 a.C., e termina com a presença dos colonos europeus. O período histórico, época estudada pela arqueologia histórica, começa com os europeus e estende-se até o presente. Estes dois períodos históricos existem em qualquer parte do Novo Mundo com presença de europeus. No Novo Mundo, o período pré-histórico foi habitado apenas por povos nativos, enquanto, em época histórica, outros povos começaram a habitar regiões anteriormente povoadas por nativos.",

Os trabalhos de prospecção foram realizados durante os anos de 1995 e 1996, quando foram identificadas 210 ocorrências de vestígios que poderiam se caracterizar como possíveis sítios históricos. Após o início dos trabalhos de salvamento, essas ocorrências foram reavaliadas, e em muitos casos reagrupadas, no caso de se tratarem de um mesmo contexto. Assim, o número final de sítios que foram pesquisados ficou em 177, sendo que, destes, apenas 106 estavam dentro da área inundável, ou seja, abaixo da cota de $460 \mathrm{~m}$ de altitude, e, portanto, constituíam-se no universo de trabalho.

Aqueles sítios que se encontravam na periferia da represa, de fato não estavam incluídos no programa de salvamento, embora fossem, em muitos casos, sítios de grande expressividade dentro do contexto histórico regional, sendo assim, merecedores de uma avaliação mais cuidadosa e até de um monitoramento no futuro, para que não venha a ocorrer um comprometimento dos vestígios localizados na área de influência direta da represa.

\footnotetext{
${ }^{1}$ ORSER Jr. Introdução à arqueologia histórica, 1992, p.18.
} 
$\mathrm{O}$ projeto acima citado tinha como objetivo desenvolver o levantamento e o salvamento dos sítios arqueológicos relacionados ao período histórico na área de influência direta e indireta do reservatório, buscando "ampliar os conhecimentos acerca do processo de colonização da área iniciado na região através da extração mineral sob o regime escravocrata, conhecer a dinâmica dos contatos interétnicos, e compreender o processo de transformação social ocorrido entre os séculos XVII e XX",2.

A identificação dos sítios não foi uma tarefa simples, por uma série de motivos, dentre os quais podem ser destacados:

- a extensão da área a ser pesquisada: o reservatório de Serra da Mesa ocupa uma área de $1784 \mathrm{~km}^{2}$ e abrange, parcialmente, oito municípios;

- a dificuldade de se atingir grande parte da área, onde o número de estradas e vias era escasso, e, quando existiam, estavam em péssimas condições de conservação;

- a dificuldade de se precisar a cota altimétrica, mesmo dispondo de equipamentos modernos, como GPS, monitorados por satélite;

- a imprecisão dos mapas da região, já que mesmo os mapas do IBGE apresentavam incorreções de destaque, como nomes dos acidentes geográficos, inclusive rios e serras;

- o clima, por ser muito quente e úmido a partir dos meses de outubro e novembro, praticamente inviabilizava os trabalhos de campo;

- a dificuldade de se identificarem os vestígios, muitas vezes pouco perceptíveis, comuns aos sítios históricos. Sobre essa dificuldade, Orser $\mathrm{Jr}^{3}{ }^{3}$ coloca que

"ao menos duas razões explicam essa dificuldade. Em primeiro lugar, a presença mais antiga de europeus no Novo Mundo é, não poucas vezes, difícil de documentar. Muitos viajantes, como os mais antigos exploradores do interior do Brasil, com freqüência deixaram apenas traços fraquíssimos de suas visitas. Seus sítios são de difícil localização e, quando achados, não raras vezes são difíceis de estudar, já que a duração de sua ocupação foi demasiadamente breve. O segundo problema deriva das questões levantadas pela presença de artefatos europeus em sítios indígenas: receberam estes indígenas aqueles itens exóticos dos europeus ou de outros índios, os quais, por sua vez, podem tê-los recebido de outros

\footnotetext{
${ }^{2}$ UNIVERSIDADE FEDERAL DE MINAS GERAIS. Projeto de prospecção e salvamento históricoarqueológico na área a ser atingida pela represa de Serra da Mesa - Goiás, 1995, p. 2.

${ }^{3}$ ORSER JR. Introdução à arqueologia histórica, 1992, p.21.
} 
indios ou de europeus? As datas dos verdadeiros contatos diretos entre europeus e índios, em geral considerados como delimitadores do início do período histórico, são difíceis (...) de se estabelecer. Como resultado, o início do período histórico apenas pode ser estabelecido a nível regional, e com freqüência, de maneira um tanto imprecisa."

A despeito das dificuldades encontradas, dos 177 sítios prospectados, 106 foram resgatados, dentro de um trabalho de campo que foi realizado em três etapas: de maio a novembro de 1996, de abril a novembro de 1997 e de maio a junho de 1998. Dentro deste conjunto de sítios trabalhados, havia a predominância daqueles referentes à atividade mineradora (antigas áreas de garimpo), relacionada ou não aos bandeirantes; sedes de antigas fazendas, muitas vezes com a presença de muros de pedra delimitadores do espaço (podendo também estar associados ou não à atividade mineradora); antigos núcleos urbanos (vestígios de vilas ou aldeias), portos, presídios e outros.

À medida que o trabalho de prospecção dos sítios histórico-arqueológicos foi se desenvolvendo, e, posteriormente, o trabalho de salvamento propriamente dito começou a ser realizado, foi-se observando no contato direto com a realidade local, que as relações das pessoas da comunidade com aqueles vestígios arqueológicos eram muito diferentes da visão do pesquisador. Portanto, passa-se a analisar essa questão sob o ponto de vista das pessoas leigas no assunto: o que é na realidade um patrimônio cultural? Qual a sua importância para uma comunidade de pessoas simples e carentes de recursos econômicos? Por que essas pessoas têm tão pouco acesso às informações sobre o seu próprio patrimônio cultural?

A partir de questionamentos como esses, passa-se a observar com mais cuidado a realidade com a qual se estava envolvido. Sobretudo buscando inserir esses e outros questionamentos dentro de uma perspectiva mais ampla: ora, se nem mesmo aquela comunidade tinha noção exata da riqueza do seu patrimônio histórico e cultural, como levar esse conhecimento para "fora" dessa comunidade? E a relação desse patrimônio com os fenômenos geográficos: como poderia ser feita? Durante os três anos de duração dos trabalhos de campo do Programa (96, 97 e 98), foram levantadas algumas hipóteses, sobretudo com relação à distribuição espacial dos sítios arqueológicos e suas características funcionais (sítios de mineração, sítios de fazenda, sítios de cemitérios, etc.). Buscou-se observar até que ponto as condições geográficas poderiam ser (ou não) determinantes do ponto de vista da 
especificação do sítio arqueológico, e, conseqüentemente, da constituição do próprio patrimônio cultural.

Outra característica que merece destaque é que, para as (poucas) pessoas das comunidades locais que se interessaram por este trabalho, a maioria absoluta buscava informações referentes a patrimônio arqueológico pré-histórico, demonstrando desinteresse quase total para com as informações sobre patrimônio histórico, indicando claramente que não se valoriza o que está mais próximo de nós (historicamente falando), e que há uma idéia formada ainda com base nas informações externas, ou seja, considera-se aquilo que o cientista ou pesquisador estrangeiro já valorizou, e não se reconhece a história do país como merecedora de divulgação, visto que não apresenta um status corroborado por nenhum grande nome da comunidade científica internacional.

Também há que se registrar o próprio fato de uma empresa como FURNAS investir elevadas cifras em projetos de salvamento arqueológico (tanto histórico quanto pré-histórico, neste caso, desenvolvido por uma equipe de pesquisadores da UFGO).

Além dos dois projetos citados, FURNAS desenvolveu também mais 15 outros projetos, envolvendo sobretudo a questão ambiental. Segundo a empresa,

"FURNAS considera o meio ambiente fundamental no desenvolvimento de suas atividades. Para tanto, a Empresa promove diversos estudos e ações de modo a compatibilizar a questão ambiental com o planejamento, projeto, construção e operação dos seus empreendimentos."

Ocorre que a Usina Hidrelétrica (UHE) de Serra da Mesa é um projeto que remonta ao final da década de 70, quando a legislação brasileira ainda não exigia estudos de impactos ambientais para obras desse porte. Em 1981 foi outorgado a FURNAS, através do Decreto no 85.923/81, de 06/05/81, a concessão para o desenvolvimento progressivo do potencial hidrelétrico existente no trecho do rio Tocantins e seus afluentes, que se estende desde as suas nascentes, ao norte de Brasília, até o paralelo $12^{\circ} \mathrm{Sul}$, próximo à cidade de Peixe, no atual estado do Tocantins.

\footnotetext{
${ }^{4}$ FURNAS CENTRAIS ELÉTRICAS S.A.A usina hidrelétrica Serra da Mesa e o meio ambiente, 1996, p.1.
} 
Em 1982, FURNAS concluiu o inventário hidrelétrico do trecho citado acima, no qual foi indicada a Usina Hidrelétrica (UHE) de Serra da Mesa, como o principal empreendimento a ser implantado.

Em 1986, foi concluído o Projeto Básico do Aproveitamento e, neste mesmo ano, foi iniciada a sua construção, mediante contrato ajustado entre FURNAS e a Camargo Correia Construtora, para a execução da primeira etapa das obras civis.

As obras de Serra da Mesa ficaram paralisadas durante grande parte do governo Fernando Collor, sendo retomadas no início da década de 90. No entanto, para que elas tivessem andamento, foi necessário o aporte de capital privado, e, através de um consórcio entre o poder público e a iniciativa privada (Bradesco e Votorantin), as obras foram reiniciadas. Já neste momento, sob uma nova legislação, que prevê todo um processo de licenciamento ambiental e para atender às exigências técnicas da Fundação Estadual do Meio Ambiente de Goiás (FEMAGO), foram elaborados os dezessete programas ambientais listados a seguir, que, segundo FURNAS, "visam a prevenir, minimizar ou compensar as alterações provocadas pela implantação e operação da Usina", . São eles:

Programa de Monitoramento Sismológico: acompanha as atividades sísmicas na região antes, durante e após o enchimento do reservatório. O monitoramento sismológico é realizado por meio da operação de uma rede sismológica operada por FURNAS, cujos dados são analisados pelo Observatório Sismológico da Universidade de Brasília.

Programa de Monitoramento Climatológico: verifica a possível interferência do reservatório no clima local. Mesmo antes da formação do reservatório de Serra da Mesa o clima local (clima tropical chuvoso, com período seco) vem sendo monitorado para detectar possíveis alterações, através de uma estação climatológica, localizada próxima à Usina. Os dados amostrados são complementados por informações colhidas de oito postos pluviométricos do extinto DNAEE (Departamento Nacional de Águas e Energia Elétrica), localizados na região, e são analisados por consultoria técnica especializada.

\footnotetext{
${ }^{5}$ FURNAS CENTRAIS ELÉTRICAS S.A.A usina hidrelétrica Serra da Mesa e o meio ambiente, 1996, p.1.
} 
Programa de Acompanhamento da Exploração Mineral: regulariza a situação dos processos minerários em pesquisa e/ou lavra, localizados na área a ser inundada. Na região sob influência do empreendimento, os principais recursos minerais pesquisados são: níquel, cobre, manganês, quartzo, zinco e chumbo. FURNAS realizou, desde 1984, gestões junto ao DNPM (Departamento Nacional de Produção Mineral), visando à regularização da situação dos processos mineratórios em pesquisa e/ou lavra, localizados na área do reservatório, de modo a bloquear novos requerimentos e promover assinatura de Termos de Renúncia para os já existentes.

Programa de Monitoramento Limnológico e da Qualidade da Água: avalia a qualidade da água no rio Tocantins e em seus principais afluentes, bem como no reservatório. Este programa visa a acompanhar a evolução da qualidade da água do reservatório, como também a identificação de problemas relacionados à poluição.

Programa de Conservação da Flora: prevê a conservação da flora da área de influência da Usina Serra da Mesa, identificando-a e resgatando sementes, mudas e outras estruturas que permitam a sua reprodução, através de convênio com a EMBRAPA (Empresa Brasileira de Pesquisa Agropecuária). Através do Centro Nacional de Pesquisa de Recursos Genéticos e Biotecnologia - (CENARGEN) promoveu-se o levantamento das espécies existentes na área do reservatório, tendo sido identificadas cerca de 330 espécies vegetais.

Programa de Conservação da Fauna Silvestre: este programa visa a atenuar os efeitos causados pela implantação da Usina na fauna silvestre. Em convênio com a NATURE - Projetos e Consultoria Ambiental, além da participação do IBAMA, da FEMAGO e do Departamento de Zoologia da Universidade de Brasília, foram realizados projetos de resgate da fauna, contemplando, ainda, o seu monitoramento em margens e algumas ilhas em formação, no reservatório.

Programa de Monitoramento da Ictiofauna: pretende atenuar os impactos causados pela formação do reservatório sobre a comunidade de peixes. A construção da Usina, ao barrar o rio Tocantins, causa alterações no ambiente aquático, sendo necessário avaliar as modificações ictiofaunísticas que sua implantação gerará, bem como obter os conhecimentos básicos necessários à administração e manejo dos recursos pesqueiros na área sob influência 
do empreendimento. O programa foi executado em convênio com a Fundação BIO-RIO e a Universidade Federal do Rio de Janeiro (UFRJ).

Programa de Consolidação de Unidades de Conservação: de acordo com a Resolução nº 002, de 18/04/96, do CONAMA (Conselho Nacional do Meio Ambiente), ficou estabelecido que

"para fazer face à reparação dos danos ambientais causados pela destruição de florestas e outros ecossistemas, o licenciamento ambiental de empreendimentos de relevante impacto ambiental, assim considerado pelo órgão ambiental competente com fundamento no EIA/RIMA, terá como um dos requisitos a serem atendidos pela entidade licenciada, a implantação de uma unidade de conservação de domínio público e uso indireto, preferencialmente uma Estação Ecológica, a critério do órgão licenciador, ouvido o empreendedor" (Artigo $1^{\circ}$ ).

Para atender ao disposto nessa Resolução, FURNAS ajustou convênios com o IBAMA (Instituto Brasileiro do Meio Ambiente e Recursos Naturais Renováveis) e com a FEMAGO (Fundação Estadual do Meio Ambiente de Goiás), sendo que o primeiro objetiva a consolidação do Parque Nacional da Chapada dos Veadeiros e a instrumentalização dos seus escritórios regionais nas cidades de Uruaçu e Alto Paraíso de Goiás, de modo a auxiliar as condições de fiscalização da flora e fauna na área sob a influência da Usina. Já o convênio com a FEMAGO busca a consolidação dos Parques Estaduais Pirineus e Terra Ronca, bem como a criação da Unidade de Conservação Serra da Mesa.

Programa de Limpeza da Bacia de Acumulação: este programa promoveu a retirada prévia e o aproveitamento de parte dos recursos florestais da área que foi inundada. Para tanto, FURNAS ajustou um Acordo de Cooperação entre o IBAMA (Instituto Brasileiro do Meio Ambiente e Recursos Naturais Renováveis) e a FEMAGO (Fundação Estadual do Meio Ambiente de Goiás). FURNAS e Serra da Mesa Energia S.A. promoveram o desmatamento de 13 trechos distribuídos ao longo de todo o reservatório, entre as cotas 460 e $440 \mathrm{~m}$, de modo a permitir um melhor uso do lago, nessas áreas. Para as áreas abaixo de 440m, contendo recursos florestais com potencial de aproveitamento econômico, foi concedido aos interessados autorização do IBAMA e da FEMAGO para a retirada prévia desse material, tendo sido registradas cerca de 107 solicitações de desmatamento. 
Programa de Comunicação Social: este programa abriu um canal de comunicação entre a Empresa e a população da região, através da distribuição de folhetos e cartazes, realização de diversas palestras e divulgação de informações sobre o empreendimento e os Programas ambientais implantados. Nos municípios de Minaçu, Niquelândia e Uruaçu, FURNAS abriu e manteve escritórios, para serem ponte de ligação entre a comunidade e a empresa.

Programa de Remanejamento e Monitoramento da População da Área de Influência Direta: para implantar a Usina Serra da Mesa, FURNAS adquiriu a área necessária, indenizando, além da terra, as benfeitorias e plantações existentes. $\mathrm{Na}$ área do atual reservatório, existiam diversas propriedades que se dedicavam à criação de gado. A maioria dos proprietários não residiam no local e grande parte das propriedades mantiveram áreas remanescentes, permitindo-se assim a continuidade de suas atividades produtivas.

Programa de Relocação da Infra-Estrutura: na área inundada pela formação do reservatório foram necessárias as relocações de 228 trechos de rodovias, sendo dois da rede federal, 5 da rede municipal e 205 da rede vicinal, além de 12 trechos de rede de energia elétrica e uma estação de tratamento de água no município de Uruaçu, o que permitiu manter as ligações e o atendimento antes existentes. As relocações foram feitas em articulação com os seguintes órgãos: DNER (Departamento Nacional de Estradas de Rodagem), DER/GO (Departamento de Estradas de Rodagem do Estado de Goiás), CELG (Centrais Elétricas de Goiás) e SANEAGO (Empresa de Saneamento de Goiás).

Programa de Saúde Pública: este projeto pretende acompanhar as mudanças que possam ocorrer no quadro sanitário em decorrência da implantação da Usina. Para tanto, FURNAS ajustou convênios com a FIOCRUZ (Fundação Instituto Oswaldo Cruz) com a FNS (Fundação Nacional de Saúde) e com o Instituto de Medicina Social da Universidade do Estado do Rio de Janeiro, prevendo o controle e acompanhamento das possíveis endemias e seus agentes transmissores. Em atendimento às demandas de saúde, foi construído e mantido o Hospital de Apoio de Minaçu. 
Programa de Gestão da Questão Indígena: através de convênio ajustado com a FUNAI, foi estabelecida a forma de compensação pela utilização de parte do território indígena pelo empreendimento da Usina, buscando desenvolver ações que promovessem a sobrevivência física e cultural dos índios Avá-Canoeiro. O programa PACTO (Programa AváCanoeiro do Tocantins) previu a relocação do Posto Indígena, indicada pelo sub-programa de Saúde, para outra área na própria reserva, bem como a demarcação da Terra Indígena AváCanoeiro, e a sua fiscalização e proteção.

Programa de Levantamento Espeleológico: com vistas ao levantamento das ocorrências espeleológicas na área do empreendimento de Serra da Mesa, o Instituo Geabrasil, em convênio com FURNAS, desenvolveu pesquisas na área do reservatório e seu entorno, ampliando as informações sobre o acervo de cavernas e contribuindo para o diagnóstico do patrimônio espeleológico nacional. Ao todo foram identificadas 159 ocorrências espeleológicas, entre cavernas, abismos, etc., com presença de espeleotemas que foram registrados e mapeados, além da coleta de representantes da fauna específica desse micro-ambiente.

\section{Programa de Monitoramento das Atividades Sócio-Econômicas e Culturais da} Área de Influência Indireta: o acompanhamento das mudanças que ocorrem nos municípios vem sendo realizado através de diagnósticos que estudam variáveis sócio-econômicas e culturais, como o aumento de população e atividades comerciais e a demanda por serviços e hábitos de consumo. Para desenvolver este programa, FURNAS interagiu com as prefeituras locais.

Programa de Recuperação do Patrimônio Arqueológico Pré-Histórico: com vistas à proteção do patrimônio Arqueológico Pré-Histórico, FURNAS firmou convênio com a Universidade Federal de Goiás, para a realização de pesquisas na área do reservatório e seu entorno, contribuindo, assim, para ampliar o conhecimento acerca do processo de ocupação por grupos pré-históricos, na bacia hidrográfica do rio Tocantins e para uma melhor compreensão a respeito da nossa pré-história. As pesquisas estiveram voltadas para as manifestações culturais anteriores ao ano de 1500, que marca o início do período histórico no Brasil, e, em linhas gerais, o fim do período pré-histórico. Foram pesquisados 91 sítios 
arqueológicos. O projeto compreendeu atividades de campo e de laboratório, com a realização de prospecção e escavação arqueológicas nos sítios selecionados.

Diante do interesse e da necessidade que FURNAS Centrais Elétricas S.A. tinha em desenvolver os programas ambientais e monitorar as alterações ambientais ocorridas na área do empreendimento, ponderou-se sobre a importância que a questão ambiental está adquirindo no Brasil, nos últimos anos: nada há que se compare com as ações e empreendimentos observados em países desenvolvidos, mas, de qualquer forma, já se registra um avanço nesse aspecto quando se compara a pouca preocupação que até um passado recente esta questão levantava nos organismos oficiais.

No entanto, se a questão ambiental vem sofrendo avanços consideráveis, devido, sobretudo, a uma maior conscientização da população em geral, não há muita certeza se, com relação ao patrimônio cultural foi possível avançar tanto, sobretudo porque, no Brasil, o patrimônio cultural, que é considerado e valorizado, está muito ligado à arquitetura e às manifestações artísticas do período colonial, sendo que inúmeras outras formas de manifestações culturais são relegadas a segundo plano ou simplesmente desconsideradas seja por puro desconhecimento ou por mero descaso das autoridades e do meio acadêmico. Este tema será discutido nos próximos capítulos.

\section{A área do empreendimento e seus objetivos:}

A área de pesquisa está localizada no interior de Goiás, incluindo a região onde foi construída a UHE - Usina Hidrelétrica de Serra da Mesa e seus arredores. A barragem da UHE Serra da Mesa está situada no curso principal do rio Tocantins, no estado de Goiás; nos municípios de Minaçu (margem esquerda) e Colinas do Sul (margem direita), a $1790 \mathrm{~km}$ de sua foz. Seu reservatório é o maior do Brasil, ocupando uma área de $1784 \mathrm{~km}^{2}$ (na cota máxima de $460 \mathrm{~m}$ ) e 5,4 bilhões de $\mathrm{m}^{3}$, atingindo partes dos municípios de Niquelândia, Minaçu, Uruaçu, Campinorte, Campinaçu, Colinas do Sul, Barro Alto e São Luís do Norte, em Goiás, de acordo com o quadro $\mathrm{n}^{\circ} 01$ e os mapas 01 e 02 . 
Quadro 01: Municípios atingidos pelo reservatório de Serra da Mesa: área de inundação

\begin{tabular}{|l|c|c|c|c|}
\hline Municípios & $\begin{array}{c}\text { Área do } \\
\text { Município } \\
\left(\mathbf{K m}^{\mathbf{2}}\right)\end{array}$ & $\begin{array}{c}\text { Área Inundada } \\
\mathbf{( \mathbf { K m } ^ { 2 } )}\end{array}$ & $\begin{array}{c}\text { área do } \\
\text { município }\end{array}$ & $\begin{array}{c}\text { \% da área } \\
\text { inundada do } \\
\text { mun. em relação } \\
\text { à área total }\end{array}$ \\
\hline Minaçu & $2.860,0$ & 47,7 & 1,7 & 2,7 \\
\hline Campinorte & $1.069,6$ & 3,5 & 0,3 & 0,2 \\
\hline Campinaçu & $1.976,9$ & 332,3 & 16,8 & 18,6 \\
\hline Colinas do Sul & $1.707,6$ & 68,5 & 4,0 & 3,8 \\
\hline Uruaçu & $2.135,3$ & 277,5 & 13,0 & 15,5 \\
\hline Niquelândia & $9.847,2$ & $1.018,7$ & 10,3 & 57,1 \\
\hline Barro Alto & $2.046,1$ & 35,8 & 1,7 & 2,0 \\
\hline São Luiz Norte & 723,8 & 0,5 & 0,1 & 0,1 \\
\hline TOTAL & $22.366,5$ & $1.784,5$ & 8,0 & 100,0 \\
\hline
\end{tabular}

Fonte: FURNAS: Projeto Básico do Aproveitamento Hidrelétrico de Serra da Mesa 
Figura 01: Localização geográfica da Usina Hidrelétrica de Serra da Mesa

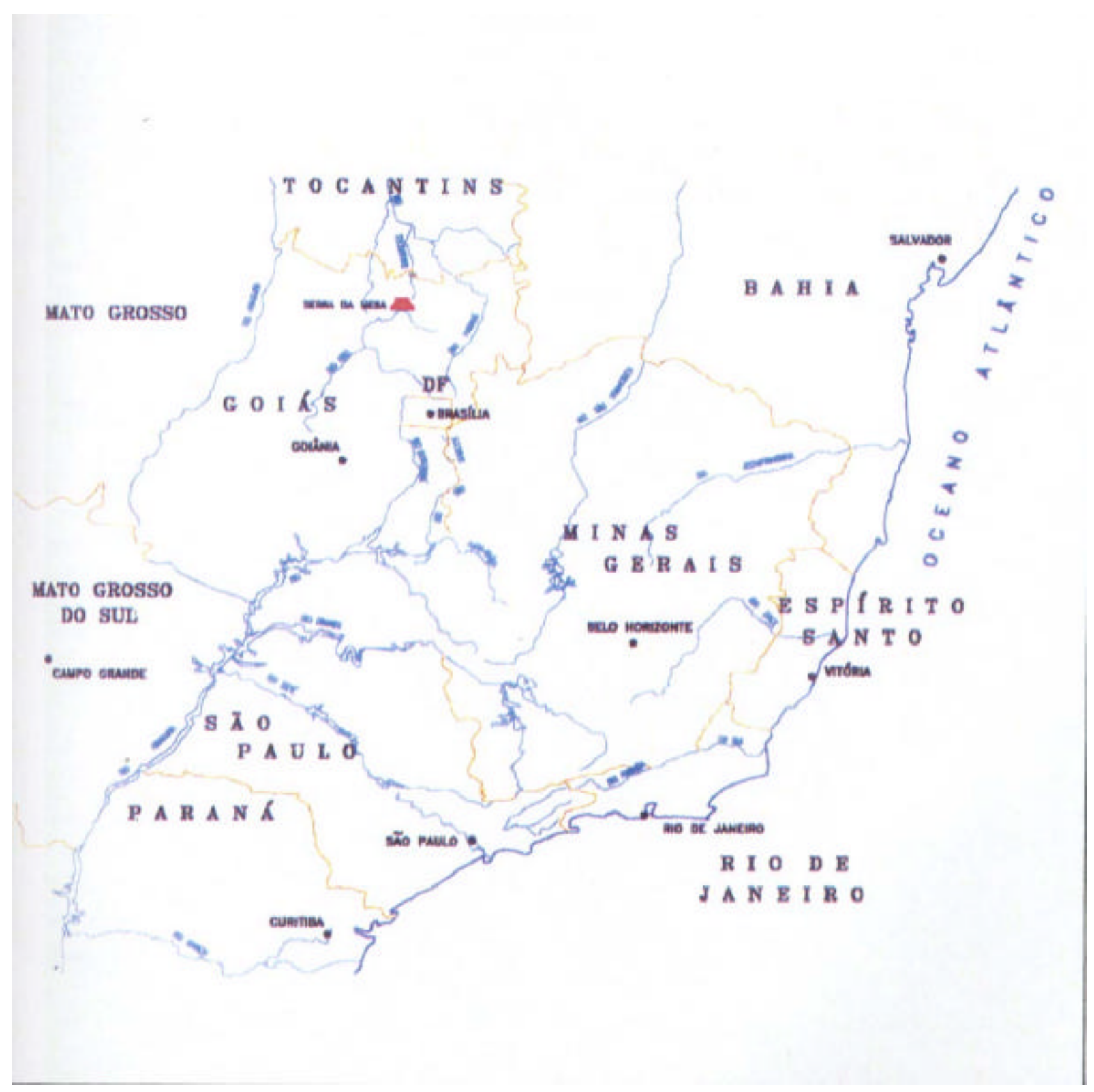

Fonte: Projeto de salvamento histórico arqueológico da área da represa de Serra da Mesa. 
Figura 02: Localização da Represa de Serra da Mesa.

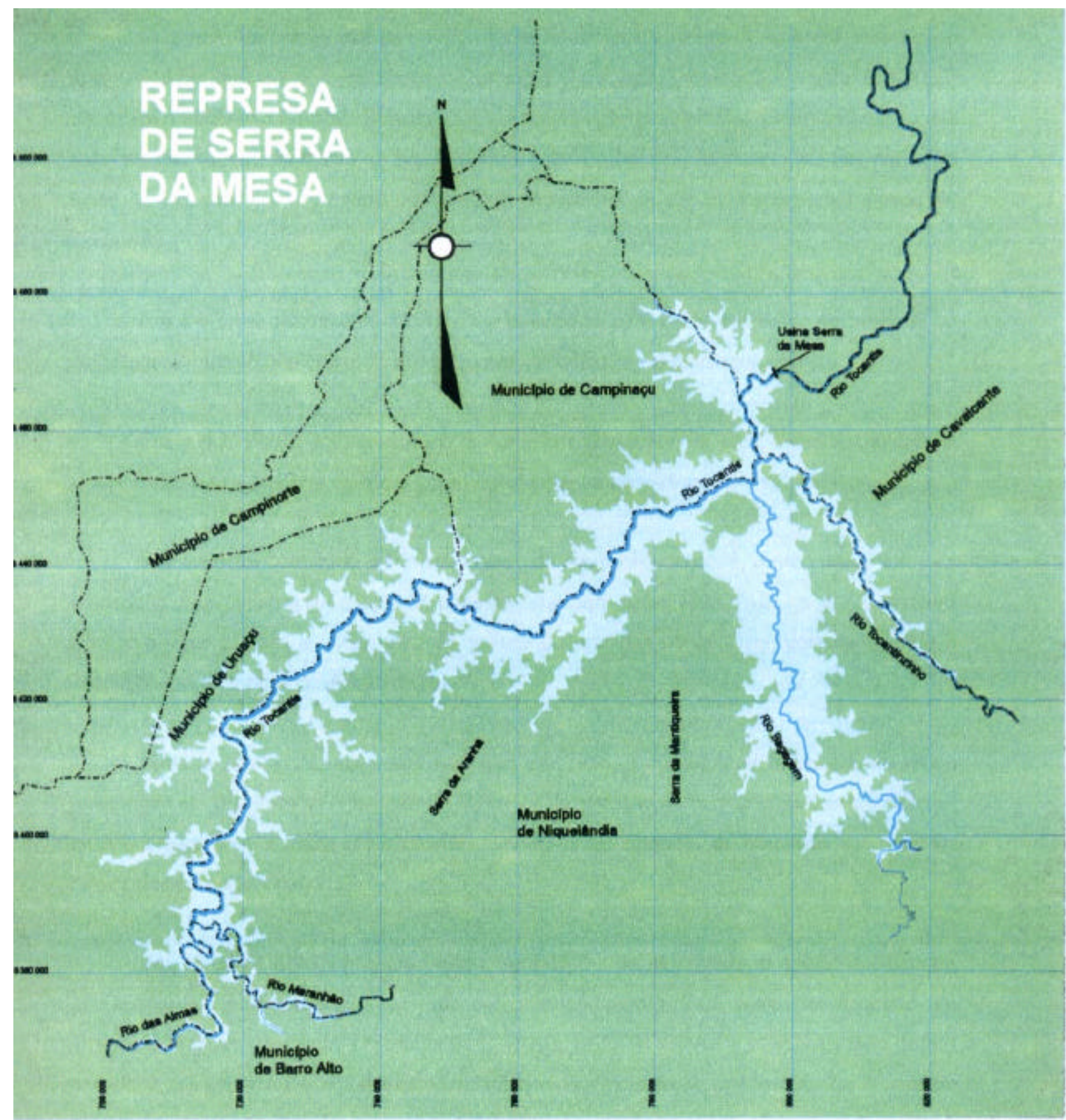

Fonte: Projeto de salvamento histórico arqueológico da área da represa de Serra da Mesa. 


\section{Histórico do projeto da usina hidrelétrica de Serra da Mesa:}

O projeto da construção da UHE - Usina Hidrelétrica de Serra da Mesa remonta ao ano de 1979, quando o Departamento Nacional de Águas e Energia Elétrica (DNAEE) concedeu a FURNAS Centrais Elétricas S.A., a autorização para estudar o aproveitamento dos recursos hidráulicos do trecho do rio Tocantins e seus afluentes, desde as suas nascentes, ao norte de Brasília, até o paralelo $12^{\circ}$ lat Sul, próximo à cidade de Peixe, atual estado do Tocantins.

Em 1981 foi outorgado à FURNAS a concessão para o desenvolvimento progressivo do potencial hidrelétrico existente nos rios compreendidos no trecho acima citado.

Em 1982, FURNAS concluiu o inventário hidrelétrico da área, ficando indicada a Usina Hidrelétrica de Serra da Mesa como o principal empreendimento a ser implantado.

Em 1986 foi concluído o Projeto Básico de Aproveitamento, e, neste mesmo ano, foi iniciada a sua construção mediante contrato ajustado entre FURNAS e a Construtora Camargo Correa, para a construção da primeira etapa das obras civis, correspondendo à execução das estruturas de desvio do rio.

Embora as obras tenham sido iniciadas em 1986, o cronograma físico acabou sendo postergado em decorrência - segundo FURNAS - da retração do mercado de energia elétrica, na época recessivo, e, mais recentemente, devido às dificuldades de obtenção dos recursos requeridos para a sua conclusão.

Em 1993, FURNAS procura buscar, junto à iniciativa privada, o aporte de recursos necessários à viabilização da conclusão do empreendimento. Para tanto, foi formado um Grupo de Trabalho que reuniu técnicos do DNAEE, ELETROBRÁS e FURNAS para definir a melhor solução para o equacionamento da questão. A solução encontrada foi o modelo inédito de participação da iniciativa privada, consistindo no arrendamento de bens e instalações de equipamento versus participação na potência e energia associada da Usina. 
Assim, a UHE de Serra da Mesa foi a primeira hidrelétrica no Brasil a ter investimentos e uso da energia divididos entre uma empresa estatal e o setor privado. A Serra da Mesa S. A. foi a empresa vencedora do Processo de seleção de parceiros. A ela coube a responsabilidade da conclusão das obras, recebendo, em contrapartida, 51,54\% da energia que a usina produzir. O BNDES financiou parte da obra, repassando recursos obtidos junto ao Banco Mundial, cujo custo estimado é da ordem de 1,7 US\$ bilhões.

Em março de 1997 a totalidade das ações da Serra da Mesa S.A. foi alienada para a VBC Energia, empresa formada pelos grupos Votorantin, Bradesco e Camargo Correa.

\section{Descrição técnica do Empreendimento:}

A barragem do aproveitamento hidrelétrico de Serra da Mesa apresenta uma capacidade instalada de 1275 MW distribuída em três unidades geradoras de 425 MW e irá produzir uma energia de cerca de $735 \mathrm{MW} /$ ano, superior em $15 \%$ ao atual mercado da CELG - Centrais Elétricas de Goiás - (639 MW/ ano - 1995). Devido à regularização do rio promovida por seu reservatório, Serra da Mesa irá proporcionar um ganho adicional de cerca de $112 \mathrm{MW} /$ ano apenas na Usina Hidrelétrica de Tucuruí, situada a jusante, no baixo curso do rio Tocantins.

O aproveitamento hidrelétrico (AHE) de Serra da Mesa, por estar localizado numa intrusão granítica, propicia características peculiares à obra, tais como a casa de força localizada em caverna no interior desse maciço e um baixíssimo consumo de concreto, se comparada com outros aproveitamentos hidrelétricos do mesmo porte.

O circuito hidráulico é todo subterrâneo, escavado em maciço rochoso "são" e "muito consistente", sendo, portanto, de excelentes propriedades geomecânicas ${ }^{6}$.

\footnotetext{
${ }^{6}$ FURNAS CENTRAIS ELÉTRICAS S. A. A questão ambiental associada à usina hidrelétrica Serra da Mesa, 1996, p.2.
} 
A barragem implantada no leito do rio Tocantins é do tipo de enrocamento com núcleo de argila (mais de $4.130 .000 \mathrm{~m}^{3}$ ), com uma crista com comprimento total de $1.510 \mathrm{~m}$ e altura máxima de $150 \mathrm{~m}$. A tomada d'água é feita em três vãos escavados na rocha e revestidos de concreto, com uma altura máxima de 70,2m e controlados por comportas tipo vagão, de 7,0m de largura por $9,0 \mathrm{~m}$ de altura.

O reservatório ocupa uma área de $1.784 \mathrm{~km}^{2}$, podendo apresentar um volume d'água que varia de 54,4 a 43, $25 \mathrm{~km}^{3}$, dependendo do NA (nível d'água), já que a cota de inundação vai de 417,3 m (para um NA mínimo normal) a 460 m (para um NA máximo normal). A cota de segurança é de 461,5m (NA máximo maximorum). O reservatório de Serra da Mesa tem uma vida útil prevista de 200 anos.

O quadro 02 apresenta as principais características desse projeto. 
Quadro 02: Principais Características do Projeto

\begin{tabular}{|c|c|}
\hline MOTORIZAÇÃO & \\
\hline Potência Instalada (MW) & 1.275 \\
\hline Energia Local (MW/ano) & 650 \\
\hline Energia Média (MW/ano) & 735 \\
\hline \multicolumn{2}{|l|}{ RESERVATÓRIO } \\
\hline Área inundada $\left(\mathrm{Km}^{2}\right)$ & 1.784 \\
\hline Volume Total $\left(\mathrm{Km}^{3}\right)$ & 54,4 \\
\hline Volume Útil $\left(\mathrm{Km}^{3}\right)$ & 43,25 \\
\hline Profundidade Média (m) & 30 \\
\hline \multicolumn{2}{|l|}{ CASA DE FORÇA } \\
\hline Tipo & Subterrânea \\
\hline Número de Unidades & 03 \\
\hline Potência Unitária (MW) & 425 \\
\hline Tipo de Turbina & Eixo Vertical \\
\hline Queda nominal (m) & 125,80 \\
\hline \multicolumn{2}{|l|}{ BARRAGEM } \\
\hline Comprimento Total da Crista (m) & 1.510 \\
\hline Altura Máxima (m) & 150 \\
\hline \multicolumn{2}{|l|}{ VERTEDOURO } \\
\hline Tipo (estrutura de concreto com calha natural) & Superfície \\
\hline Cota da Soleira (m) & 441 \\
\hline Comprimento da Soleira (m) & 96 \\
\hline Número de Vãos (unidade) & 05 \\
\hline Dissipação de Energia & Canal de energia \\
\hline \multicolumn{2}{|l|}{ SISTEMA ADUTOR (CANAL) } \\
\hline Comprimento médio (m) & 225 \\
\hline Largura ou Seção & Variável \\
\hline \multicolumn{2}{|l|}{ TOMADA D'ÁGUA } \\
\hline Tipo & $\begin{array}{l}\text { Escavada em rocha } \\
\text { revestida de concreto }\end{array}$ \\
\hline Número de Vãos (unidade) & 03 \\
\hline Altura Máxima (m) & 70,2 \\
\hline Largura da Comporta Tipo Vagão (m) & 7,0 \\
\hline Altura da Comporta Tipo Vagão (m) & 9,0 \\
\hline Acionamento & Guincho Hidráulico \\
\hline
\end{tabular}

Fonte: Furnas Centrais Elétricas S.A. Projeto Básico Ambiental do Aproveitamento Hidrelétrico Serra da Mesa - Implantação dos Programas Ambientais. 1996 


\section{CAPÍtUlO I}

PATRIMÔNIO CULTURAL: COMPROMISSO COM O FUTURO

"A cultura é e deve ser uma consciência."

(Bareyten Breytenbach) 


\section{PATRIMÔNIO CULTURAL: COMPROMISSO COM O FUTURO}

No Brasil, a expressão patrimônio cultural tem conquistado cada vez mais espaço na mídia, sobretudo após o fato de alguns conjuntos arquitetônicos do período colonial brasileiro terem sido considerados patrimônios culturais da humanidade pela UNESCO. Tal fato reflete sobretudo a importância que se tem dado aos bens patrimoniais arquitetônicos e/ou artísticos que remontam ao período colonial brasileiro, cuja expressividade é de fato grandiosa.

No entanto, não se pode deixar de salientar que o patrimônio cultural de um povo estende-se para muito além dos bens acima citados. Ocorre que, em um país sem tradição quanto à preservação e divulgação de sua própria cultura, como é o caso do Brasil, tem-se dificuldade de identificar diferentes elementos que remetam com segurança ao próprio patrimônio cultural brasileiro. 
Aliado a este fato, há também que se analisar a questão econômica, visto que trata-se de bens de valor muitíssimo elevado nos mercados imobiliário e artístico, cujo potencial comercial identifica aos seus proprietários possibilidades visíveis de lucro, ao passo que determinados bens culturais, com menor status, são desconsiderados como tal.

De qualquer forma, para se discutir com clareza sobre patrimônio cultural, faz-se necessário identificar, também, com clareza, tanto quanto seja possível, o que é patrimônio cultural e quais as suas formas de manifestação.

De acordo com Lemos ${ }^{7}$, o patrimônio cultural é o acervo maior de uma nação ou de um povo, e abrange todo o elenco de bens denominados "culturais" porque, "entre todos eles, quaisquer que sejam os atributos que se lhes der, existe forte travamento de relações estabelecidas". Ainda de acordo com Lemos, citando a definição de Hugues de VarineBoham, o Patrimônio Cultural pode ser dividido em três grandes categorias de elementos:

"Primeiramente, arrola os elementos pertencentes à natureza, ao meio ambiente. São os recursos naturais, que tornam o sítio habitável. Nesta categoria estão por exemplo os rios, a água desses rios, os seus peixes, a carne desses peixes, as suas cachoeiras e corredeiras, etc. (...)

"O segundo grupo de elementos refere-se ao conhecimento, às técnicas, ao saber e ao saber fazer. São os elementos tangíveis do Patrimônio Cultural. Compreende toda a capacidade de sobrevivencia do homem no seu meio ambiente. Vai desde a perícia do rastejamento de uma caça esquiva na floresta escura até às mais altas elocubrações matemáticas apoiadas nos computadores de última geração, que dirigem no espaço cósmico as naves interplanetárias que estão a ampliar o espaço vital do homem. (...)

"O terceiro grupo de elementos é o mais importante de todos porque reúne os chamados bens culturais que englobam toda sorte de coisas, objetos, artefatos e construções obtidas a partir do meio ambiente e do saber fazer. Aliás, a palavra artefato talvez devesse ser a única a ser empregada no caso, tanto

\footnotetext{
${ }^{7}$ LEMOS.O que é patrimônio histórico,. 1985, p.8.
} 
designando um machado de pedra polida como um foguete interplanetário, ou uma igreja ou a própria cidade em volta dessa igreja”

De fato, o patrimônio cultural de um povo ou nação pode se estender por uma infinidade de objetos, lugares, conhecimentos, bens móveis e imóveis, etc. O que vai de fato servir como parâmetro para um determinado bem ser definido como patrimônio cultural é, na verdade, o conjunto de relações estabelecidas entre as pessoas e o elemento em questão, devendo, neste conjunto de relações, estar implícito o desenvolvimento cultural, manifestado ao longo do tempo.

Patrimônio cultural está intimamente ligado com o passado, que só se busca identificar na medida em que se procura constituir a própria identidade, que foi ou está sendo construída ao longo do tempo. A busca da identidade é fato cada vez mais marcante nas sociedades modernas. Segundo Arantes ${ }^{8}$,

"há a crescente organização e mobilização de segmentos sociais os mais variados que somam forças em torno de interesses - ou da percepção e reivindicação de direitos - talvez. os mais fundamentais do que os decorrentes da propriedade privada. Como que toma forma, nestes dias, a vontade coletiva de defender o que constitui e que, ao mesmo tempo, é testemunho de experiências comuns, que são pensadas como história compartilhada”.

Além disso,

"para nenhum grupo humano o espaço vital é um conjunto de objetos físicos, vazios de significado. Toda cultura, antiga ou moderna, de nações política e socialmente complexas ou de pequenos grupos de caçadores e coletores nômades, transforma $o$ 'espaço físico' em 'lugar', 'território', ou 'lar'. Essa regra não se aplica apenas aos espaços privados, ao interior das casas ou aos locais de culto. Ruas, caminhos, praças, campos e montanhas, rios, praias e o mar são apropriados pelos grupos humanos de acordo com concepções que são próprias de seus modos de vida". 9

Considerando que patrimônio cultural é um conjunto mais amplo de bens e valores, Vesentini diferencia patrimônio histórico de patrimônio ecológico, embora considerando ambos como sendo partes integrantes do patrimônio cultural:

\footnotetext{
${ }^{8}$ ARANTES. Produzindo o passado: estratégias de construção do patrimônio cultural,1984, p.8.
} 
"o patrimônio cultural inclui e subsume tanto o histórico como o ecológico. Pois o que é histórico, digno de registro, de perpetuação, símbolo de gerações passadas, o é somente frente ao nosso presente e aos nossos valores e dilemas culturais." 10

A expressão patrimônio cultural remete a uma reflexão: trata-se de um conjunto cada vez mais vasto de bens e conhecimentos, e que será cada vez mais vasto quanto mais complexa for a sociedade em questão. De qualquer forma, mesmo sendo tão amplo, ter-se-á que considerar a valorização que a sociedade dará ao seu patrimônio. Por vezes, muitos objetos que são considerados sem importância, dentro de uma sociedade, num dado momento histórico, passa a ser considerado como de grande valor histórico e cultural, a partir do momento em que ganha representatividade dentro da cultura onde está ou esteve inserido. É o que faz a arqueologia: busca conhecer e explorar objetos abandonados, perdidos ou de uso cotidiano, para reconstituir a vida e a cultura de comunidades passadas ou de momentos culturais diferentes do atual.

No Brasil, Patrimônio Histórico e Artístico já foi sinônimo de Patrimônio Cultural (denominação dada pelo SPHAN - Serviço do Patrimônio Histórico e Artístico Nacional). No entanto, a expressão Patrimônio Cultural é bem mais ampla, porque inclui tanto o aspecto histórico quanto o ecológico.

Para Paoli, é necessário estar-se atento quanto ao uso indiscriminado de termos, tais como "história, memória, patrimônio, passado," tendo em vista que

"nenhuma destas palavras tem sentido único. Antes, formam um espaço de sentido múltiplo, onde diferentes versões se contrariam, porque saídas de uma cultura plural e conflitante. A noção de 'patrimônio histórico' deveria evocar estas dimensões múltiplas da cultura com imagens de um passado vivo: acontecimentos e coisas que merecem ser preservadas porque são coletivamente significativas em sua diversidade" ${ }^{11}$.

\footnotetext{
${ }^{09}$ ARANTES. Produzindo o passado: estratégias de construção do patrimônio cultural, 1984, p.9

${ }^{10}$ VESENTINI. Geografia, natureza e sociedade, 1997, p.52.

${ }^{11}$ PAOLI. Memória, história e cidadania: o direito ao passado. In: CUNHA. O direito à memória: patrimônio histórico e cidadania, 1992, p.25.
} 
Na definição de Jézus Ataídes,

"o Patrimônio Cultural é constituído de bens culturais, que são a produção dos homens nos seus aspectos emocional, intelectual e material e todas as coisas que existem na natureza. Tudo o que permite ao homem conhecer a si mesmo e ao mundo que o rodeia pode ser chamado de bem cultural." 12

Ainda de acordo com o mesmo autor, o Patrimônio Cultural pode ser dividido em quatro categorias: os bens naturais, que são os elementos pertencentes à natureza; os bens de ordem material, que são as criações dos homens, como as coisas, os objetos e as construções; os bens de ordem intelectual, que são os "saberes" do homem, o seu conhecimento; e por fim os bens de ordem emocional, que representam o sentimento individual ou coletivo, como, por exemplo, as manifestações folclóricas e cívicas.

Assim, pode-se considerar como sendo Patrimônio Cultural todo o conjunto de bens materiais ou não, mas que seja representativo da história de uma determinada sociedade e que a ela confere identidade.

A identidade cultural de uma comunidade pode ser observada a partir da soma de suas características mais marcantes, que vão sendo construídas ao longo do tempo e que a distingue das demais. Constituem elementos diferenciadores, e, portanto, capazes de conferir identidade a uma comunidade a(s) sua(s) religião(ões), as classes sociais que a compõem, suas etnias com seus costumes, seus aspectos geográficos, históricos e outros. A soma desses elementos conferirá, ao longo do tempo, essa caracterização coletiva, que irá individualizar o grupo em questão.

Um grupo, uma comunidade ou uma sociedade, assim definidos, através da sua identidade cultural, precisará, para se perpetuar ao longo do tempo, estabelecer formas de preservá-la, sob o risco de se descaracterizar. E isso só será possível através da memória. “É ela que armazena as informações, os conhecimentos, as experiências, tanto em nível individual como social ou

\footnotetext{
${ }^{12}$ ATAÍDES, MACHADO \& SOUZA. Cuidando do patrimônio cultural, 1997, p.11.
} 
coletivo."13 Pierre Nora, citado por Jézus Ataídes, op. cit., define memória como sendo “o que fica do passado no vivido dos grupos, ou o que os grupos fazem do passado”.

E então, a partir da necessidade de se preservar a memória do grupo, faz-se também necessário organizar e legitimar os processos que envolvem essa tarefa. Para tanto, urge criarse uma legislação capaz de primeiro identificar e depois permitir, definir e/ou exigir a preservação do Patrimônio Cultural, bem comum a todos.

A Constituição Brasileira de 1988, no seu artigo 216, esclarece que

“constituem Patrimônio Cultural brasileiro os bens de natureza material e imaterial, tomados individualmente ou em conjunto, portadores de referência à identidade, à ação, à memória ${ }^{14}$ dos diferentes grupos formadores da sociedade brasileira”, nos quais se incluem:

I - as formas de expressão;

II - os modos de criar, fazer e viver;

III - as criações científicas, artísticas e tecnológicas;

IV - as obras, objetos, documentos, edificações e demais espaços destinados às manifestações artístico-culturais;

V - os conjuntos urbanos e sítios de valor histórico e paisagístico, artístico, arqueológico, paleontológico, ecológico e científico.

\section{O patrimônio cultural e a legislação}

A depredação dos bens patrimoniais e culturais é uma questão preocupante, e não pode continuar acontecendo sob as vistas da sociedade, sem que nada seja feito. Sobre o tema Souza Filho ${ }^{15}$ coloca que:

\footnotetext{
${ }^{13}$ ATAÍDES, MACHADO \& SOUZA. Cuidando do patrimônio cultural, 1997, p.15.

${ }^{14}$ Grifo nosso

${ }^{15}$ SOUZA FILHO. Bens culturais e proteção jurídica., 1997, p.11.
} 
"O mundo já tomou consciência de que é necessário colocar freios na ação devastadora e degradadora com que tem tratado a natureza e as culturas. Os bens ambientais, como gênero, e os culturais, como espécie, começam a ser protegidos pelas sociedades, de tal modo que já estão sendo impostas importantes alterações nos sistemas jurídicos.

"Por isso, apesar de a sociedade transformar-se com acelerada velocidade, é suicídio o pleno desenvolvimento sem a compreensão de que a humanidade necessita da natureza e dos marcos de civilização que evocam as gerações antecedentes. (...)

"Apesar da conscientização e da legislação protecionista cada vez mais presentes, não há dúvida de que os bens ambientais, naturais e culturais por eles representadas. (...) Por isto, de forma tão elegante quanto precisa, a Unesco alerta para a importância de os países preservarem e cuidarem do patrimônio cultural neles localizado: 'Templos y castillos, grutas de cazadores paleolíticos, sabanas, glaciares, palacios barrocos, salinas, frescos medievales, ruinas misteriosas de los desiertos de Asia y de los bosques americanos, peñones y catedrales. Moenjodaro y Roma, estatuas y volcanes... ¿ Qué tienen en común estos edificios y estos espacios vírgines, separados por miles de kilómetros o decenas de siglos, estas maravillas naturales y culturales, tanto objetos díspares? Todos poseen dos caracteristicas: En primer lugar, cada uno de ellos es considerado único, invalorable, irreemplazable. Todos esos bienes formam parte del patrimonio mundial, cultural y natural. En segundo lugar, todos están en peligro.”

Diante do perigo constante da destruição - parcial ou total, reversível ou não - faz-se necessário elaborar leis e mecanismos que efetivamente resguardem e perpetuem o Patrimônio Cultural e Ambiental de toda e qualquer sociedade. 


\subsection{Legislação Federal: Histórico:}

Como se viu anteriormente, definir patrimônio cultural não é tarefa fácil. De acordo com Lemos ${ }^{16}$, "são tantos os patrimônios quantas são as inúmeras compartimentações da sociedade e seus interesses." Estes interesses expressam-se na preocupação que a sociedade tem de elaborar leis que lhe garantam a preservação do seu patrimônio. Mas, para preservar, faz-se necessário definir, demarcar, conceituar, classificar, compartimentar. Ainda segundo Lemos, na sociedade brasileira a preocupação com patrimônio cultural é relativamente recente, embora, em 1742, o Conde de Galveias já alertava as autoridades pernambucanas para a descaracterização do Palácio das Duas Torres, de primorosa arquitetura holandesa, transformado em quartel para as tropas locais. Segundo o Conde,

"seria imprescindível a manutenção da integridade daquela obra holandesa, verdadeiro troféu de guerra a orgulhar o nosso povo, e com as adaptações previstas estaria arruinada 'uma memória que mudamente estava recomendando à posteridade as ilustres e famosas ações que obraram os Portugueses na Restauração dessa Capitania' (...) Dizia, ainda, que aquelas obras holandesas 'são livros que falam sem que seja necessário lê-los..",17

Segue-se, na história brasileira, longo período em que as autoridades mantêm-se em discreto silêncio que acaba compactuando com a destruição e/ou depredação do patrimônio do país. Nenhuma preocupação com a preservação da memória ou da história da nação, salvo

\footnotetext{
"somente um ou outro particular, algum colecionador ou intelectual afeito às coisas históricas é que se lembrava e solicitava fossem defendidos os nossos monumentos arquitetônicos - monumentos no sentido grandiloqüente porque do patrimônio popular ninguém nunca se lembrou mesmo. (...)
}

De qualquer forma,

\footnotetext{
${ }^{16}$ LEMOS. O que é patrimônio histórico, 1985, p.32.

${ }^{17}$ LEMOS. O que é patrimônio histórico, 1985. p.35.
} 
"o conjunto da legislação protecionista pertence ao amplo espectro do Direito Público, porque trata de definições de interesse público sobre bens que ficam sob a tutela da Administração, ainda que sejam de domínio privado. No Brasil - e em todos os sistemas jurídicos ocidentais -, a proteção jurídica do meio ambiente e dos bens culturais é recente, não tendo mais de cinco décadas (...)

"No ano de 1922, que acabou por se constituir no marco da defesa dos bens culturais da Nação brasileira tanto no plano intelectual, como no legal, aparece, tímido, o primeiro ato legislado de proteção cultural, a criação do Museu Histórico Nacional - decreto $n^{o} 1.596$, de 02 de agosto de 1922 - que limitava o seu objeto já no preâmbulo: 'será da maior conveniência para o estudo da História Pátria reunir os objetos a ela relativos que se encontram nos estabelecimentos oficiais $e$ concentrá-las em museu, que os conserve, classifique e exponha ao público, e, enriquecido com os obtidos por compra, por doação ou legado, contribua, como escola de patriotismo, para o culto de nosso passado...'

"O texto do decreto não continha a idéia de preservação geral de objetos e bens considerados relevantes para o conhecimento da História Nacional. A finalidade da entidade recém criada se limitava à preservação dos bens já integrantes do patrimônio público, ou que viessem a ser adquiridos, sem adiantar qualquer critério para estas aquisições" 18.

Em 1923, o deputado Luiz Cedro apresentou o projeto de lei $n^{\circ}$ 350/1923 destinado a salvar o Patrimônio do país, sugerindo a criação da Inspetoria dos Monumentos Históricos dos Estados Unidos do Brasil, para o fim de “conservar os imóveis públicos ou particulares, que no ponto de vista da história ou da arte revistam um interesse nacional”. Para definir-se quais seriam os imóveis considerados "de interesse", o processo seria bem simples: a Inspetoria deveria apresentar anualmente uma relação de edifícios para serem classificados, pelo então ministro da Justiça, como sendo monumentos nacionais.

"O projeto não estabelecia diferença entre bens privados e públicos, estipulando que se ficasse provada a insuficiência de meios aos proprietários para os reparos urgentes ao imóvel classificado, o governo poderia adiantar

\footnotetext{
${ }^{18}$ SOUZA FILHO. Bens culturais e proteção jurídica, 1997, p.41.
} 
'por empréstimo a despropriação', isto é, se não houvesse pagamento, seria desapropriado. O projeto não foi aprovado, mas seu mérito foi o de abrir uma discussão sobre a intervenção do Estado na ordem econômica, não prevista para a Constituição de 1891, então vigente e, do ponto de vista dos institutos jurídicos, de criar este empréstimo-desapropriação, que é de relevante interesse público e nunca pôde existir no Direito brasileiro." 19

Em 1925, a pedido do governador mineiro Presidente Mello Vianna, o jurista Jair Lins também elaborou um anteprojeto, onde buscava defender os bens representativos de nosso passado, alegando que, desde os mais remotos tempos, é a arte o elemento diferenciador entre os homens e os animais. Lins faz um retrospecto da História Ocidental, buscando demonstrar que, desde os tempos da Roma antiga, já existiam manifestações legais de proteção ao Patrimônio Cultural e Artístico da humanidade. Alega, ainda, que diversos países “civilizados" já se preocupavam, naquela ocasião, com a preservação do seu patrimônio cultural, e cita cerca de quinze países que dispunham de dispositivos legais protecionistas.

Pode-se identificar um grande avanço nesse anteprojeto, porque, pela primeira vez na história do Brasil, mencionam-se "móveis", ou seja, objetos de maneira geral, dentre os bens que seriam passíveis de conservação.

É importante ressaltar que, como jurista, Jair Lins teve uma clara preocupação de ressaltar a importância da garantia do direito de propriedade. Nessa época imperava, no Direito Brasileiro, a idéia da supremacia absoluta do interesse individual sobre o coletivo ou público. De acordo com o texto do anteprojeto,

"firmado, assim, o direito do Estado a intervir diretamente para a tutela do Patrimônio artístico, cumpre esboçar sua esfera de ação de modo a se evitar o choque de interesses. É que a ação tutelar do Estado encontra, no campo do direito, o interesse legítimo do proprietário que, por isso mesmo que o é, não pode ser feito ou desrespeitado, não só porque isto importaria em se agir contra o direito, mas porque atentaria contra a garantia estabelecida no Pacto fundamental."

\footnotetext{
${ }^{19}$ SOUZA FILHO. Bens culturais e proteção jurídica, 1997, p.42.
} 
De acordo com Souza Filho ${ }^{20}$,

\begin{abstract}
"a visão de forte tendência civilista do autor, fez com que o projeto fosse calcado em institutos jurídicos, privados, como a compra e venda. No artigo primeiro não se definiam os bens de interesse de conservação, apenas instituía que o Poder Público deveria catalogá-los e, a partir desta catalogação, não seria permitida nenhuma transação onerosa, por ato inter vivos, sem que fossem oferecidas à União ou ao Estado. Além disso, é claro, os imóveis catalogados não poderiam ser demolidos, consertados ou reparados sem prévia autorização oficial. Previa o projeto que, se o proprietário não quisesse ou não pudesse proceder às obras de restauro ou recuperação necessárias, deveriam notificar o órgão do Estado que teria três opções: realizar as obras às custas do Estado; desapropriar o bem; cancelar o registro ou catalogação. No caso de interesse de exportação dos bens culturais, a situação se repetia: o proprietário notificaria o Estado, que deveria exercer seu direito de preferência ou o país perderia o bem cultural. Este anteprojeto, que nunca chegou a tramitar no Congresso Nacional, é apenas um documento não oficial que, a despeito disso, serviu de base de estudo, junto com outros, para a legislação vigente".
\end{abstract}

Como a aprovação de uma legislação que tivesse abrangência nacional mostrava-se difícil, alguns Estados começaram a buscar providências legais que permitissem salvaguardar os seus respectivos patrimônios. A Bahia e Pernambuco foram os precursores neste campo, criando, já em 1927, as suas Inspetorias Estaduais de Monumentos Nacionais.

Em 1930, houve nova tentativa frustrada de se criar uma lei federal que legislasse sobre a questão do Patrimônio Cultural no país. Naquela ocasião, o então deputado baiano José Wanderley, sensibilizado diante do grande acervo cultural e artístico de que o seu Estado era dotado, apresenta ao Congresso Nacional um novo projeto de lei sobre o assunto, que recebeu o número 230/1930. Pela primeira vez, o termo Patrimônio era utilizado para designar o acervo de bens culturais do país, definido no seu artigo primeiro, incluindo aí os bens de valor artístico, significação histórica e notável beleza, "quer pertençam à União, aos Estados, ao Distrito Federal, aos Municípios, à coletividade ou a particulares”. Esse projeto

${ }^{20}$ SOUZA FILHO. Bens culturais e proteção jurídica, 1997, p. 43. 
era composto por 31 artigos e era bastante amplo, mas como ocorreu a Revolução de 30 e a dissolução do Congresso Nacional, acabou sendo engavetado.

Um fato marcante, em termos patrimoniais, ocorre em 1933: através do Decreto $\mathrm{n}^{\circ}$ 22.928, de 18 de julho, a cidade mineira de Ouro Preto foi instituída como Monumento Nacional. Este decreto era inovador sob dois aspectos: primeiro, incluía a expressão Patrimônio Histórico e Artístico, pela primeira vez; e segundo, apresentava um grande avanço do ponto de vista jurídico, explicitando, em seu texto, que a proteção do Patrimônio artístico da Nação é um dever do Estado.

Em 1936, o então Ministro da Educação e Cultura, Gustavo Capanema, decidiu criar um serviço de proteção dos bens culturais e para tanto convidou Mário de Andrade, então diretor do Departamento de Cultura da Cidade de São Paulo, para organizá-lo.

Mário de Andrade elaborou um projeto bastante amplo, em que apresentou a definição de Patrimônio Artístico Nacional como sendo "todas as obras de arte pura ou aplicada, popular ou erudita, nacional ou estrangeira, pertencentes aos poderes públicos, e a organismos sociais e a particulares nacionais ou estrangeiros residentes no Brasil”. Desse modo, o autor procurava englobar toda manifestação da cultura brasileira, sob quaisquer formas que fossem: artefatos, música, culinária, contos e lendas, costumes e outros.

Em janeiro de 1937 já havia sido criado o SPHAN - Serviço do Patrimônio Histórico e Artístico Nacional - ,que limita a sua atuação ao conjunto dos bens móveis e imóveis existentes no país e cuja conservação seria de interesse público, quer por sua vinculação a fatos memoráveis da história do Brasil, quer por seu excepcional valor arqueológico ou etnográfico, bibliográfico ou artístico. Além destes, estabeleciam-se também como bens passíveis de preservação os “monumentos naturais" e os "sítios e paisagens que importe conservar e proteger pela feição notável com que tenham sido dotados pela natureza ou agenciados pela indústria humana." 
O SPHAN, bem como o seu Conselho Consultivo, estavam ligados ao Ministério da Educação e Saúde Pública, oficializados através da promulgação da Lei $n^{\circ}$ 378, de 13 de janeiro de 1937. No entanto, ainda no ano de 1936, o ministro

"Gustavo Capanema submeteu ao presidente Getúlio Vargas um anteprojeto de lei para definir a proteção do Patrimônio Histórico e Artístico do país, já com base na Constituição de 34. $O$ projeto seguiu trâmite rápido e foi aprovado na Câmara dos Deputados, recebeu emendas no Senado e foi aprovado, devendo retornar à Câmara. A votação das emendas do Senado estava prevista para a ordem do dia 10 de novembro de 1.937. Neste mesmo dia, por uma irônica coincidência histórica, um golpe de Estado dissolve o Congresso Nacional, entrando em vigor uma Constituição muito mais efetiva na defesa do patrimônio cultural. Seguindo esta vontade, o Estado Novo editou, com vinte dias de existência, o Decreto-Lei $n^{\circ}$ 25/37, de 30 de novembro de 1.937, que organiza a proteção do Patrimônio Histórico e Artístico Nacional"21.

Em 2 de janeiro de 1946, através de Decreto-Lei o SPHAN é transformado em Diretoria, e cria quatro distritos da DPHAN, com sedes em Recife, Salvador, Belo Horizonte e São Paulo, e subordina à Diretoria o Museu da Inconfidência, o Museu das Missões e o Museu do Ouro.

Somente em 26 de julho de 1961 é que ocorre a promulgação da Lei $n^{\circ} 3.924$, que dispõe sobre os monumentos arqueológicos e pré-históricos. Outro importante marco para o Patrimônio Nacional é a aprovação da Lei $n^{\circ} 4.845$, de 19 de novembro de 1965, que proibia a saída, para o exterior, de obras de artes e ofícios produzidas no país, até o fim do período monárquico.

Em 27 de junho de 1973, através do Decreto nº 66.967, a DPHAN foi transformada em Instituto (IPHAN).

Atualmente, cabe ao IPHAN - Instituto do Patrimônio Histórico e Artístico Nacional identificar, proteger, promover e difundir o patrimônio cultural brasileiro, embora também seja de responsabilidade dos estados, municípios e da sociedade como um todo a tarefa de

\footnotetext{
${ }^{21}$ SOUZA FILHO. Bens culturais e proteção jurídica, 1997, p.44..
} 
proteger, fiscalizar e valorizar os bens culturais, sejam eles locais, regionais ou nacionais. Portanto, pode-se dizer também que a forma de preservar está intimamente ligada à questão da educação. Só através da conscientização da sociedade como um todo e com o apoio irrestrito do poder público, é que é possível desenvolver a sensibilidade diante da importância dos bens culturais, mesmo que estes bens formem um universo muito maior do que uma simples coleção de objetos artísticos, como bem coloca Carlos Lemos:

"Preservar não é só guardar uma coisa, um objeto, uma construção, um miolo histórico de uma grande cidade velha. Preservar também é gravar depoimentos, sons, músicas populares e eruditas. Preservar é manter vivos, mesmo que alterados, usos e costumes populares. É fazer, também, levantamentos de qualquer natureza, de sítios variados, de cidades, de bairros, de quarteirões significativos dentro do contexto urbano., 22

Numa rápida análise, Souza Filho ${ }^{23}$ coloca que, em maior ou menor grau, todas as constituições brasileiras trazem em seus textos o amparo à cultura e a proteção dos bens culturais, sendo que, obviamente, os textos vão-se aprimorando e tornando-se cada vez mais amplos. No início do século passado "a tradição civilista do Direito e, em especial, com a concepção do direito de propriedade absoluto e intocável" foram argumentos capazes de impedir que prosperassem os projetos que impunham limitação ao exercício da propriedade privada, sob a alegação de que não se poderia legislar contra o direito do proprietário.

No entanto, este panorama foi-se alterando aos poucos, e sobretudo através dos movimentos sociais ocorridos ao longo do século passado, impuseram-se reformas constitucionais profundas que resultaram na mudança da própria concepção de Estado e também de Direito. Assim é que aos poucos vai-se delineando uma nova noção de propriedade, sendo que fica patente que a proteção cultural e ambiental também faz parte das obrigações do proprietário.

Nas duas últimas décadas, no Brasil, tem sido possível a luta pela preservação dos bens constituintes do nosso Patrimônio Cultural, através dos dispositivos legais da Constituição Federal de 1988, quando novos parâmetros jurídicos foram estabelecidos.

\footnotetext{
${ }^{22}$ LEMOS. O que é patrimônio histórico, 1985, p.29.

${ }^{23}$ SOUZA FILHO. Bens Culturais e Proteção Jurídica, 1997, p.44.
} 
O texto desta Constituição é muito mais profundo do que todas as outras que a precederam, tendo dispensado uma seção inteira aos bens culturais e à cultura.

Segundo a análise de Souza Filho, no texto constitucional de 1988

"o próprio conceito de Patrimônio Cultural do artigo 216 refere-se à identidade nacional. A cultura protegida é a praticada, criada e representativa das mais diversas camadas da população, o que, em termos sociológicos, é o povo. Nesta nova conceituação, a cultura brasileira passou a ser considerada com valores muito próximos aos idealizados por Mário de Andrade no começo do século" 24.

Observa-se também um avanço em relação à definição de responsabilidades para com estes bens culturais. São considerados como bens da União "as cavidades naturais subterrâneas e os sítios arqueológicos e pré-históricos" (artigo 20), e estabelece uma maior participação e co-responsabilidade entre os poderes públicos federal, estadual e municipal na tarefa de salvaguardar e proteger o Patrimônio Cultural brasileiro (artigo 23). Estende-se mais ainda, quando define que “compete à União, aos Estados e ao Distrito Federal legislar concorrentemente sobre a proteção ao Patrimônio histórico, cultural, artístico, turístico e paisagístico" (artigo 24) e aos municípios compete "promover a proteção do patrimônio histórico-cultural local, observada a legislação e a ação fiscalizadora federal e estadual”.

Definido o objeto, ou seja, tudo aquilo que é passível de preservação, e definidas as responsabilidades do poder público em suas diversas instâncias, resta avaliar o como preservar? Diversas vezes a legislação brasileira buscou soluções para esta questão. Mas preservar não é tarefa fácil. Sobretudo em um país cujas instituições públicas se apresentam de maneira pouco eficiente e em geral desarticuladas entre si, e em dissonância entre os interesses privados e os interesses da coletividade. Para alguns autores, como Cunha, os esforços realizados até agora neste sentido foram insuficientes:

"De forma geral, tem faltado empenho em sucessivos $e$ diferentes governos em fazer deste trabalho algo mais que um apêndice inútil da burocracia estatal. Não que as elites brasileiras tenham abandonado qualquer preocupação com o

\footnotetext{
${ }^{24}$ SOUZA FILHO. Bens culturais e proteção jurídica, 1997, p.48
} 
assunto: afinal, elas criaram os órgãos públicos de proteção do Patrimônio histórico. Ao fazê-lo, porém, trataram de cristalizar uma memória que reside em poucos lugares e pertence a muito poucos". ${ }^{25}$

No entanto, uma boa política de preservação dos bens culturais e patrimoniais consiste não apenas em resgatar o que já foi ou está sendo destruído, mas também de impedir ou minimizar ações que ponham em risco os bens que ainda estão intactos. Para tanto, a ação do Estado é fundamental, sobretudo quando, em muitas situações, é ele o agente causador da destruição. É o caso de Serra da Mesa. A ação do Estado foi, primeiramente, a de permitir a depredação do Patrimônio Cultural e Paisagístico da região em questão, onde, a partir da formação da represa, todos os bens naturais e culturais de uma região, de cerca de $1800 \mathrm{~km}^{2}$ passaram a ser irremediavelmente destruídos. Em seguida, e em contrapartida, a ação do Estado deve passar a ser a de exigir um "resgate" da memória cultural desta mesma área, através dos diversos programas de salvamento dos Patrimônios histórico, pré-histórico, faunístico. Para tanto, "é necessária a presença do Estado e do Direito, criando normas e ações reguladoras e protetoras" ${ }^{26}$.

A despeito das discussões em sentido contrário, no Brasil algumas leis ganham destaque diante da importância do tema e da sua própria abrangência. De qualquer forma, a legislação, embora recente, vem sendo aprimorada, e aos poucos vai ganhando maior alcance. Observem-se algumas leis que sobressaem dentro do contexto geral:

\subsection{Lei de Tombamento}

Quanto ao patrimônio arquitetônico, a legislação brasileira atua de forma mais eficaz. Talvez pelo fato de o Brasil ser extremamente rico do ponto de vista arquitetônico, quando se pôde analisar e inspirar-se na legislação de outros países, e talvez pelo fato de que os

\footnotetext{
${ }^{25}$ CUNHA.Patrimônio histórico e cidadania: uma discussão necessária, In:CUNHA.O direito à memória, 1992 , p.9.

${ }^{26}$ SOUZA FILHO. Bens culturais e proteção jurídica, 1997, p.62.
} 
monumentos arquitetônicos são mais facilmente passíveis de controle pela sociedade como um todo. O certo é que, através do tombamento, inúmeros bens culturais e ambientais tiveram (ou pretendiam ter) a sua proteção e preservação assegurados.

Embora tratando-se de um decreto que já conta com um pouco mais de 60 anos de longevidade, o Decreto-Lei $n^{\circ}$ 25/1937 é ainda um dos mais importantes instrumentos de proteção ao Patrimônio Cultural e Artístico Brasileiro. O objeto de proteção, para o decretolei, é o conjunto de bens móveis e imóveis existentes no país e cuja conservação seja de interesse público. Souza Filho faz severas críticas ao critério utilizado por essa legislação para definir quais são os bens passíveis de tombamento. Para o autor, esta definição é deficiente na medida em que não é suficiente para garantir a preservação da cultura brasileira porque não valoriza a

"profunda diversidade do ser cultural brasileiro. As mais de duzentas nacionalidades indígenas, os diversos grupos negros $e$ a variada composição de europeus e asiáticos, não se transformam, em duzentos ou trezentos anos, em 'valor arqueológico, etnográfico, bibliográfico ou artístico' mas formam fortes pressões e manifestações de cultura própria, miscigenada aqui, transfigurada ali, mas capaz de formar uma arquitetura, um desenho, uma música singular" 27.

Ainda de acordo com o autor, a Lei de Tombamento é deficiente porque

"não está entre seus objetivos a proteção das manifestações diretas da cultura brasileira, mas daquilo que, no Brasil, é reconhecido como cultura universal. (...) A lei brasileira tem ensejado à administração federal uma ação voltada para a proteção da arquitetura colonial e imperial do litoral norte e nordeste do Brasil”.

"O tombamento é um atributo que se dá ao bem cultural escolhido e separado dos demais para que, nele, fique assegurada a garantia da perpetuação da memória. Tombar, enquanto for registrar, é também igual a guardar, preservar. $O$ bem tombado não pode ser destruído e qualquer intervenção por que necessite passar deve ser analisada e autorizada." 28

${ }^{27}$ SOUZA FILHO. Bens culturais e proteção jurídica, 1997, p. 51. 
Ocorre que, o fato de um imóvel ser tombado, não implica que ele seja desapropriado. Ele continua sob a posse e o usufruto do seu proprietário, sendo que este se torna responsável pela sua integridade. Há aí um problema que ocorre comumente nos centros urbanos brasileiros: um cidadão que tenha o seu imóvel tombado (diante talvez da situação de "deseducação" ambiental e cultural citada anteriormente por Lemos) sente-se, freqüentemente, prejudicado, uma vez que ele não poderá dispor do seu bem da forma que lhe aprouver, nem mesmo introduzir-lhe modificações físicas, gerando, assim, uma desvalorização imobiliária imediata.

De qualquer forma o tombamento é um mecanismo de preservação, ainda que crie um descontentamento gerado pela expectativa de lucro ou de interferência no sagrado direito de propriedade. O certo é que

“esse complexo processo chamado de 'preservação' envolve restrições e diretrizes técnico-administrativas específicas, investimentos financeiros que gerarão expectativas de rentabilidade, tipos especiais de intervenção física (obras de conservação e restauro) e a reinterpretação funcional das edificações (a questão da reciclagem)" ${ }^{29}$.

O fato é que a política oficial de preservação do Patrimônio Cultural e Ambiental é que serve de parâmetro para definir o que será preservado. E a partir dessa definição, pode-se alterar a função social da propriedade. Segundo Souza Filho ${ }^{30}$

"uma casa de moradia urbana, que cumpra sua função social por servir de residência, quando tombada como patrimônio cultural, passa a ter também a função social de preservar a memória e evocar uma manifestação cultural, isto é, agrega, amplia, a função social da propriedade. (...) A função social dos bens socioambientais está na sua dimensão de proteção, seja para evocar a cultura, seja para garantir a biodiversidade. Em qualquer caso, cumprirá a função social só pela sua existência incólume”.

Assim, o proprietário de um prédio ou de uma área tombada pelo Patrimônio como sendo um bem cultural, passa a "dividir" o direito sobre esse bem com a comunidade

\footnotetext{
${ }^{29}$ LEMOS. O que é patrimônio histórico, 1985, p. 85.

${ }^{29}$ ARANTES. Documentos históricos, documentos de cultura, Revista do Patrimônio, no 22, 1987, p.52.
} 
beneficiada, sem, no entanto, perder os seus direitos de proprietário. Poder-se-ia dizer que, neste caso, a comunidade passa também a exercer direitos sobre o bem em questão. Ocorre algo similar com as obras de arte, por exemplo, em que o proprietário detém alguns direitos sobre o bem, como a liberdade de comercializá-la, reproduzi-la. No entanto, os seus direitos sobre a obra não são ilimitados, não podendo o seu proprietário destrui-la, por exemplo, nem negar-lhe a verdadeira autoria. Dessa forma, o proprietário tem os seus direitos limitados por um outro - o direito do autor - expresso em camadas, e que é reconhecido pelos juristas. Além deste, há também o direito coletivo, ou seja, aquele que a comunidade tem sobre o patrimônio, em que, sob determinadas condições, o público tem o direito de desfrutar daquela obra de arte, através de exposições, por exemplo.

Outro aspecto importante, que há de ser considerado, é o fato de que embora a legislação seja o instrumento que garanta a eficácia da ação pública, a lei por si só mostra-se insuficiente para garantir a preservação dos bens patrimoniais históricos e culturais.

"O exemplo disso é o esforço de setores da sociedade civil e de órgãos de imprensa e a inanição dos órgãos competentes para a repressão da venda, em especial para turistas estrangeiros vale dizer exportação ilegal - de peixes, insetos e vegetais petrificados, encontrados em sítios paleontológicos, apesar de clara proibição da Lei de Sambaquis" 31 .

\subsection{Lei dos Sambaquis}

Lei $\mathrm{n}^{\mathrm{o}} 3.924$, de 26 de julho de 1.961, dispõe sobre os monumentos arqueológicos e pré-históricos. Esta lei vem preencher uma das grandes lacunas deixadas na proteção dos bens culturais brasileiros, uma vez que põe, sob a guarda e a proteção do Poder Público, os monumentos arqueológicos ou pré-históricos e todos os elementos neles existentes. A Constituição de 1.946, então em vigor, previa, através do seu artigo ${ }^{\circ} 152$, que a propriedade

\footnotetext{
${ }^{31}$ SOUZA FILHO. Bens culturais e proteção jurídica, 1997, p.21-22..

${ }^{31}$ SOUZA FILHO. Bens culturais e proteção jurídica, 1997, p.55.
} 
das jazidas arqueológicas históricas ou pré-históricas, além dos objetos nelas incorporados, é completamente distinta da propriedade de superfície.

Assim, a Lei dos Sambaquis baseia-se no artigo 152, e define o que seriam considerados como monumentos: as jazidas de cultura paleoameríndia, os sítios com vestígios de ocupação paleoameríndia, os sítios com vestígios humanos de interesse arqueológico ou paleoetnográfico, as inscrições rupestres e/ou os locais com sulcos de polimento de utensílios. Embora seja bastante ampla, a lei dá especial atenção aos sambaquis, daí o seu nome.

Embora a propriedade do solo seja distinta da propriedade da jazida, não é possível realizar-se uma escavação arqueológica sem que se interfira nos terrenos. Dessa forma, os trabalhos de pesquisa arqueológica que envolvam escavações, quando realizados por particulares, necessitam de expressa autorização do órgão encarregado do Patrimônio Cultural, e, para se obter essa autorização, faz-se necessária a autorização, por escrito, do proprietário da área onde o sítio se encontra - salvo se esta área for de propriedade do Poder Público. Caso o proprietário venha a criar dificuldades ou procurar impor algum impedimento para que se realize a pesquisa, o Poder Público pode vir a pedir a sua desapropriação, alegando ser de utilidade pública. De acordo com a lei que trata das desapropriações por utilidade pública, a desapropriação pode ocorrer de forma temporária, ocorrendo a indenização, ao final, por ação própria, de terrenos não edificados, vizinhos às obras e necessários à sua realização.

Esta lei dispõe também, no seu artigo $\mathrm{n}^{\circ} 17$, sobre a posse e venda dos objetos arqueológicos, instituindo que a posse e salvaguarda constituem "direito imanente do Estado”, proibindo a sua comercialização sem a prévia autorização dos órgãos competentes. Ocorrendo a violação deste dispositivo, o objeto deverá ser apreendido e encaminhado ao órgão responsável pela guarda do patrimônio histórico e artístico nacional. Tanto o DecretoLei $n^{\circ}$ 25/37 quanto a lei $n^{\circ} 3824 / 61$ estabelecem, de forma expressa, a proibição de exportações de bens culturais. 


\subsection{Lei 6938/81}

No Brasil, a Lei Federal no 6938, de 31 de agosto de 1981, dispõe sobre a política nacional do meio ambiente, cujo objetivo é

\footnotetext{
"a preservação, melhoria e recuperação da qualidade ambiental propícia à vida, visando assegurar, no país, condições ao desenvolvimento sócio-econômico, aos interesses da segurança nacional e à proteção da dignidade da vida humana, atendidos os seguintes princípios:

I - Ação governamental na manutenção do equilíbrio ecológico, considerando o meio ambiente como um patrimônio público a ser necessariamente assegurado e protegido, ${ }^{32}$ tendo em vista o uso coletivo;

II - Racionalização do uso do solo, do subsolo, da água e do ar; III - Planejamento e fiscalização do uso dos recursos ambientais;

IV - Proteção dos ecossistemas, com a preservação de áreas representativas;

$V$ - Controle e zoneamento das atividades potencial ou efetivamente poluidoras;

VI - Incentivos ao estudo e à pesquisa de tecnologias orientadas para o uso racional e a proteção dos recursos ambientais;

VII - Recuperação de áreas degradadas;

VIII - Proteção de áreas ameaçadas de degradação;

IX - Educação ambiental a todos os níveis do ensino, inclusive a educação da comunidade, objetivando capacitá-la para participação ativa na defesa do meio ambiente."
}

Souza Filho coloca que,

"de qualquer forma, é clara a existência de uma relação jurídica muito precisa e ao mesmo tempo muito ampla entre direitos coletivos sobre a preservação de bens e o direito individual de uso e gozo. O centro da limitação jurídica que os direitos coletivos impõem aos individuais não está no como ter, como usar, como fruir, mas no como evitar que deteriore. "33

\footnotetext{
${ }^{32}$ Grifo nosso

${ }^{33}$ SOUZA FILHO. Bens culturais e proteção jurídica, 1997, p. 17-18.
} 
Neste aspecto, parece-nos de fundamental importância o último item mencionado no texto da Lei supra citada: a questão da educação da comunidade. Nenhum tipo de medida impetrado por qualquer órgão que seja será de fato eficaz se a população não tiver consciência da importância dos bens culturais e ambientais com os quais convive. Em verdade, grande parte de todo processo de degradação ambiental ocorre devido à desinformação ou falta de educação ambiental. Faz-se necessário, de forma urgente e abrangente, que sejam implantados programas visando a cumprir o que dispõe esse artigo $2^{\circ}$ da Lei 6938: educação ambiental a todos os níveis de ensino.

O certo é que, na prática, tal dispositivo não vem sendo cumprido. Sendo a Lei datada de agosto de 1981, já se teria pelo menos 20 anos de divulgação da importância da defesa do meio ambiente e de tudo o que ele representa para a sociedade como um todo. Embora 20 anos seja ainda pouco, já se teria percebido, na prática, algum tipo de resultado mais eficaz para as questões ambientais. No entanto, o que se observa é que, a despeito do interesse dos grandes grupos financeiros e industriais, que em busca do lucro mais imediato coloca em segundo plano as questões ambientais, a maioria da população que constitui a sociedade brasileira - sobretudo aquela parcela menos favorecida em termos de renda e acesso aos meios de educação, consumo, segurança, etc. - não se identifica com as causas ambientalistas. Numa sociedade em que os índices de miserabilidade são cada vez mais alarmantes, as questões ambientais e culturais ganham caráter utópico.

Para Ataídes ${ }^{34}$,

"é preciso desenvolver a sensibilidade e a consciência das nossas crianças, jovens e adultos sobre essa necessidade mediante um trabalho educacional. Ao lado da educação para o trânsito, para o meio ambiente e da orientação sexual, deve-se incluir também a Educação Patrimonial em nossas escolas."

\footnotetext{
${ }^{34}$ ATAÍDES, MACHADO \& SOUZA. Cuidando do patrimônio cultural, 1997, p. 33.
} 
Sobre o assunto, Lemos ${ }^{35}$ coloca que, no Brasil, torna-se um elemento dificultador para as ações de preservação

"a falta de esclarecimento popular sobre a importância da
preservação de nosso Patrimônio, para não dizermos
deseducação coletiva. Esse é um dado brasileiro e daí a
formulação de mais uma regra: a preservação aqui entre nós
depende fundamentalmente da elucidação popular, um caminho
já percorrido por outros países como o México, que dedica
atenção toda especial a essa questão da educação de massa no
que diz respeito à memória”.

Essa falta de consciência ambiental e cultural pôde ser presenciada, no Brasil, na prática durante os trabalhos de campo realizados na área da pesquisa, durante os anos de 1996, 1997 e 1998, quando se trabalhou no Projeto de Salvamento Histórico Arqueológico da Área de Serra da Mesa. A comunidade local é formada, em sua grande maioria, por pessoas simples, de baixo índice de escolaridade, pouco informada sobre as questões políticas e sociais do país e com muito pouca vivência fora de sua região de moradia. No contato direto que foi estabelecido com grande número de moradores da área, pode-se constatar que, em se tratando de uma região de exploração aurífera, (ainda que essa atividade seja extremamente incipiente nos dias atuais), os cuidados com a preservação do meio ambiente e dos elementos culturais tornam-se uma preocupação praticamente inexistente. Diante da fragilidade da economia local (sobretudo para a população de baixa renda), o imediatismo financeiro supera largamente as questões ambientais, e o fator cultural insere-se nesse contexto como mero elemento coadjuvante, podendo até ser levado em consideração, desde que não interfira nos mecanismos de busca e constituição da renda familiar.

Dessa forma, não há preocupação em preservar animais silvestres, por exemplo. Se existir um comprador, sempre haverá um vendedor de exemplares da fauna silvestre local (papagaios, araras, tucanos, etc.). Igualmente, não há a preocupação em utilizar-se dragas no leito dos rios para vasculhar o cascalho em busca de ouro, e o mercúrio é utilizado largamente pela grande maioria desses garimpeiros atuais (mesmo sabendo que o retorno é mínimo, uma vez que a produção aurífera está em franca decadência já há algumas décadas). Como conseqüência, além da contaminação das águas, ocorre o assoreamento dos leitos dos rios. A devastação da

${ }^{35}$ LEMOS. O que é patrimônio histórico, 1985, p.84. 
vegetação é outro aspecto assustador; desde as queimadas até a derrubada das árvores com a utilização de tratores com correntes são práticas comuns.

A foto 1 indica uma área que sofreu, num passado recente, grande processo de degradação pela ação dos garimpeiros que se utilizam de máquinas e tratores no processo de retirada e lavagem de sedimentos. A foto foi feita próximo ao rio do Peixe, município de Niquelândia, área de mineração antiga, que após o início das obras da UHE de Serra da Mesa passou por um processo de reativação da prática de garimpo predatório, estendendo-se por vários quilômetros em suas margens.

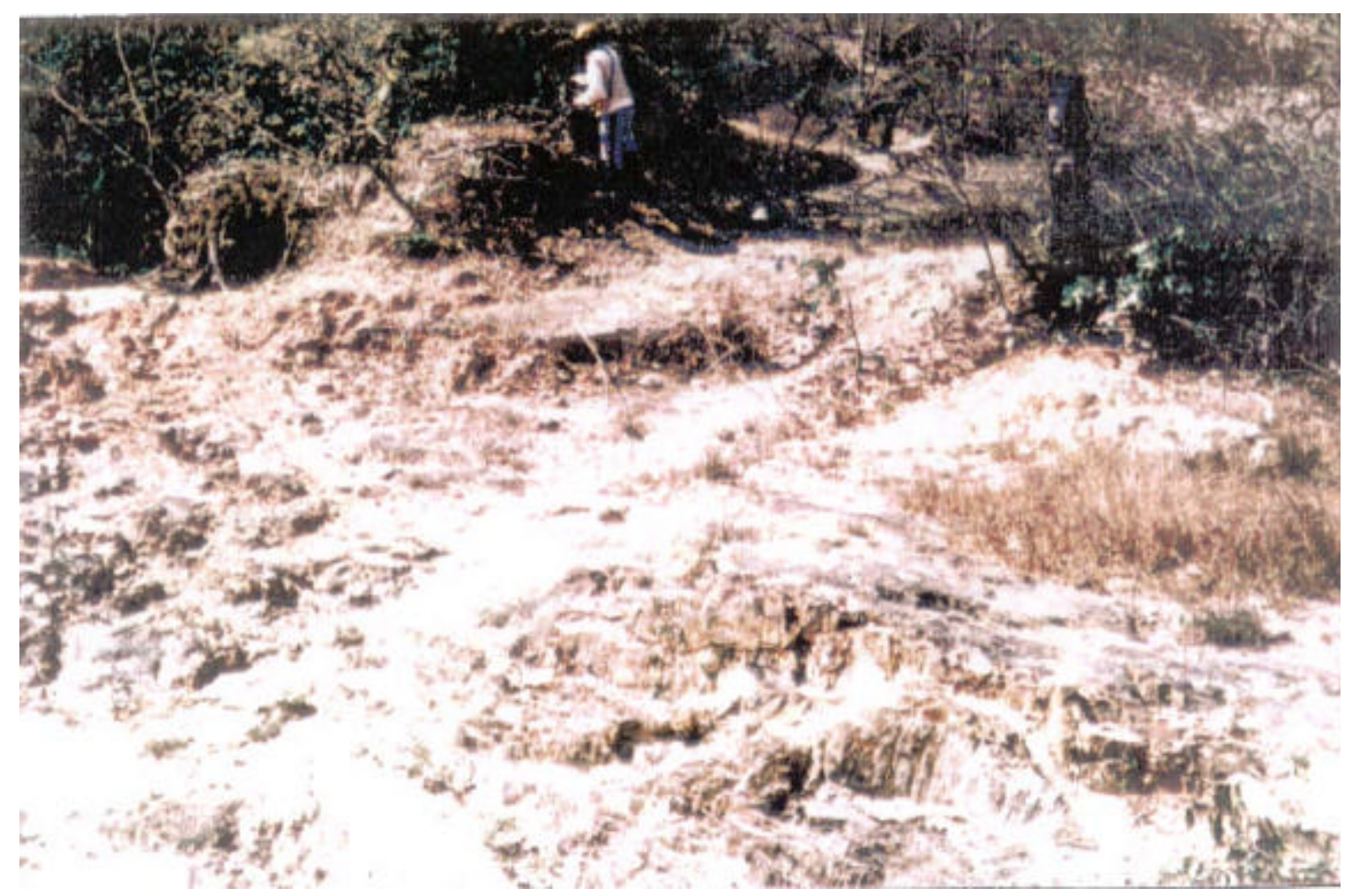

Foto 01: Área garimpada com o uso de trator, rio do Peixe, município de Niquelândia.

(Foto: UFMG/Projeto de Salvamento Histórico-arqueológico na área da represa de Serra da Mesa). 
As fotos 2, 3 e 4 mostram importantes áreas de desmatamento clandestino dentro da área de abrangência da represa de Serra da Mesa. A foto 2 foi feita próxima ao sítio arqueológico denominado de Garimpo de Talco, e as fotos 3 e 4 próximas ao sítio Cachoeira do Machadinho, onde após a derrubada das árvores com utilização de trator, procedeu-se à queimada da vegetação não aproveitada.

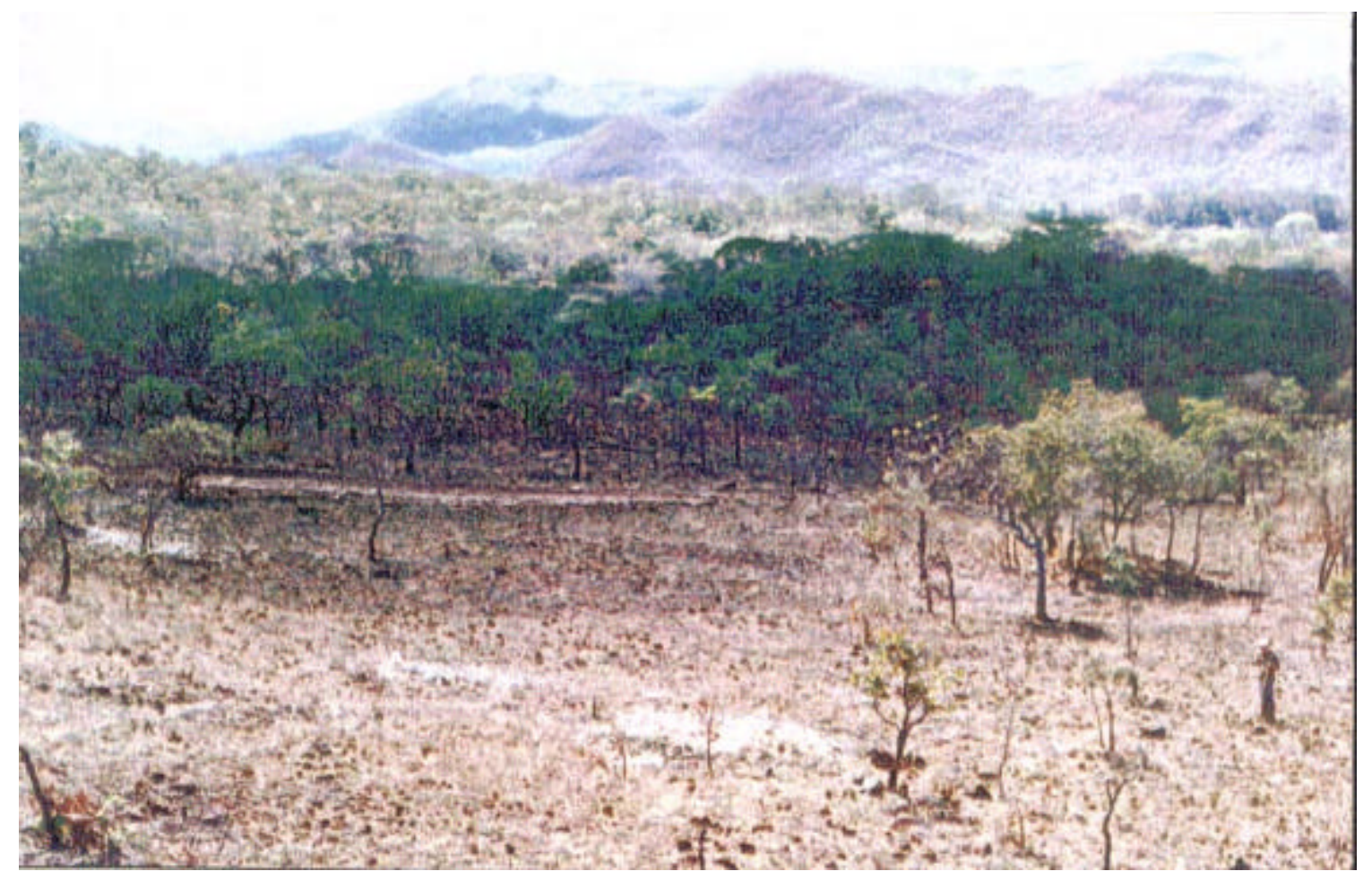

Foto 02: Área de desmatamento clandestino, próximo ao sítio Garimpo de Talco.

(Foto: UFMG/Projeto de Salvamento Histórico-arqueológico na área da represa de Serra da Mesa). 


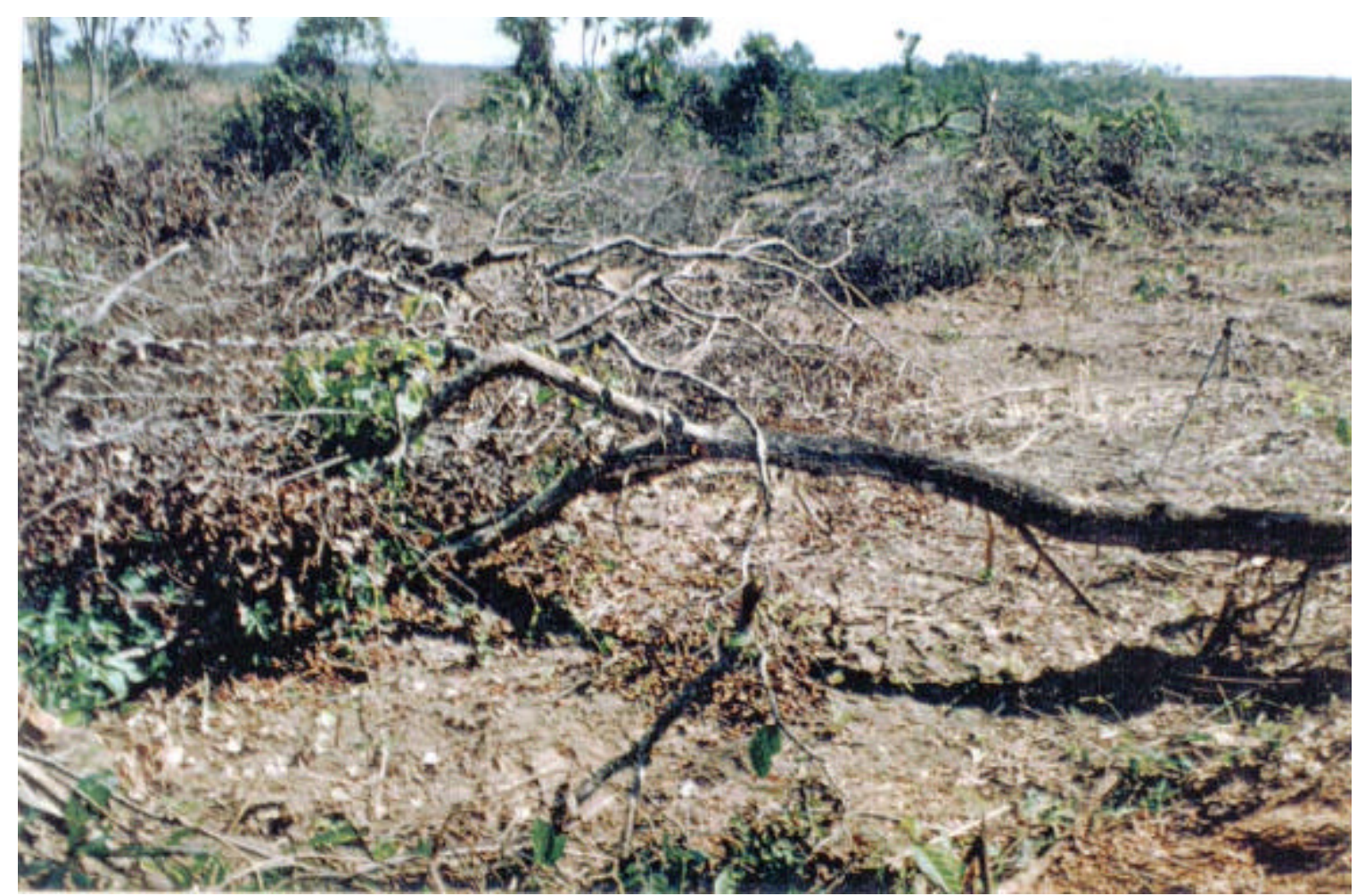

Foto 03: Desmatamento clandestino realizado com o uso de trator.

(Foto: UFMG/Projeto de Salvamento Histórico-arqueológico na área da represa de Serra da Mesa)

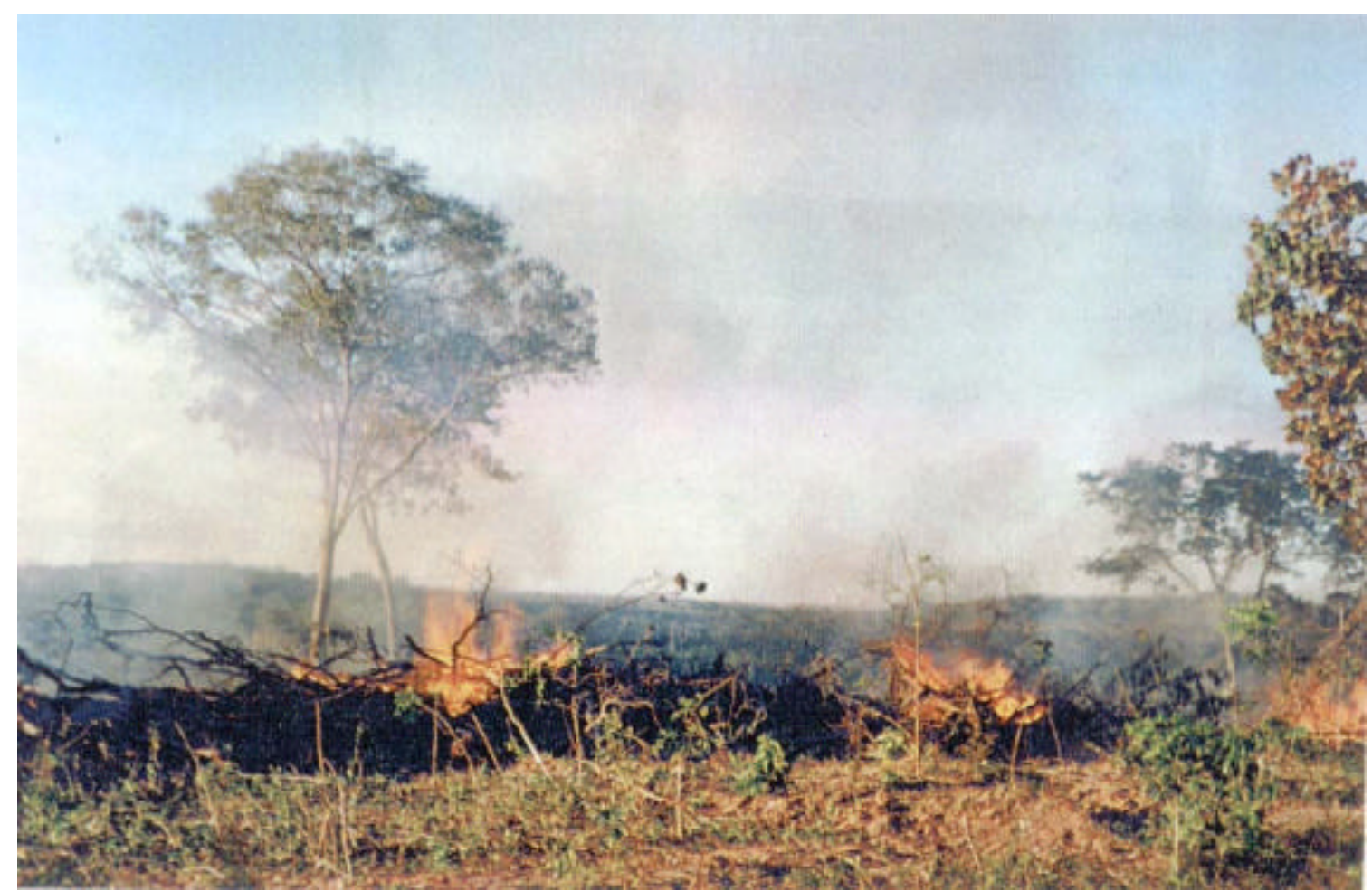

Foto 04: Queimada após desmatamento.

(Foto: UFMG/Projeto de Salvamento Histórico-arqueológico na área da represa de Serra da Mesa). 
Com os bens culturais a preocupação não é maior. Era também comum encontrar-se monumentos histórico-arqueológicos depredados pela ação de aventureiros, "caça-tesouros", que sempre os associam a riquezas e tesouros escondidos.

A foto 5 mostra um importante sítio arqueológico, denominado como Taperão do Frade, cujos vestígios - na foto o muro de pedras - já haviam sido parcialmente destruídos por pessoas da comunidade, que estão sempre em busca de ouro entrerrado, deixados pelos antigos moradores sob os alicerces ou sob o piso das antigas moradias, crença muito comum na região.

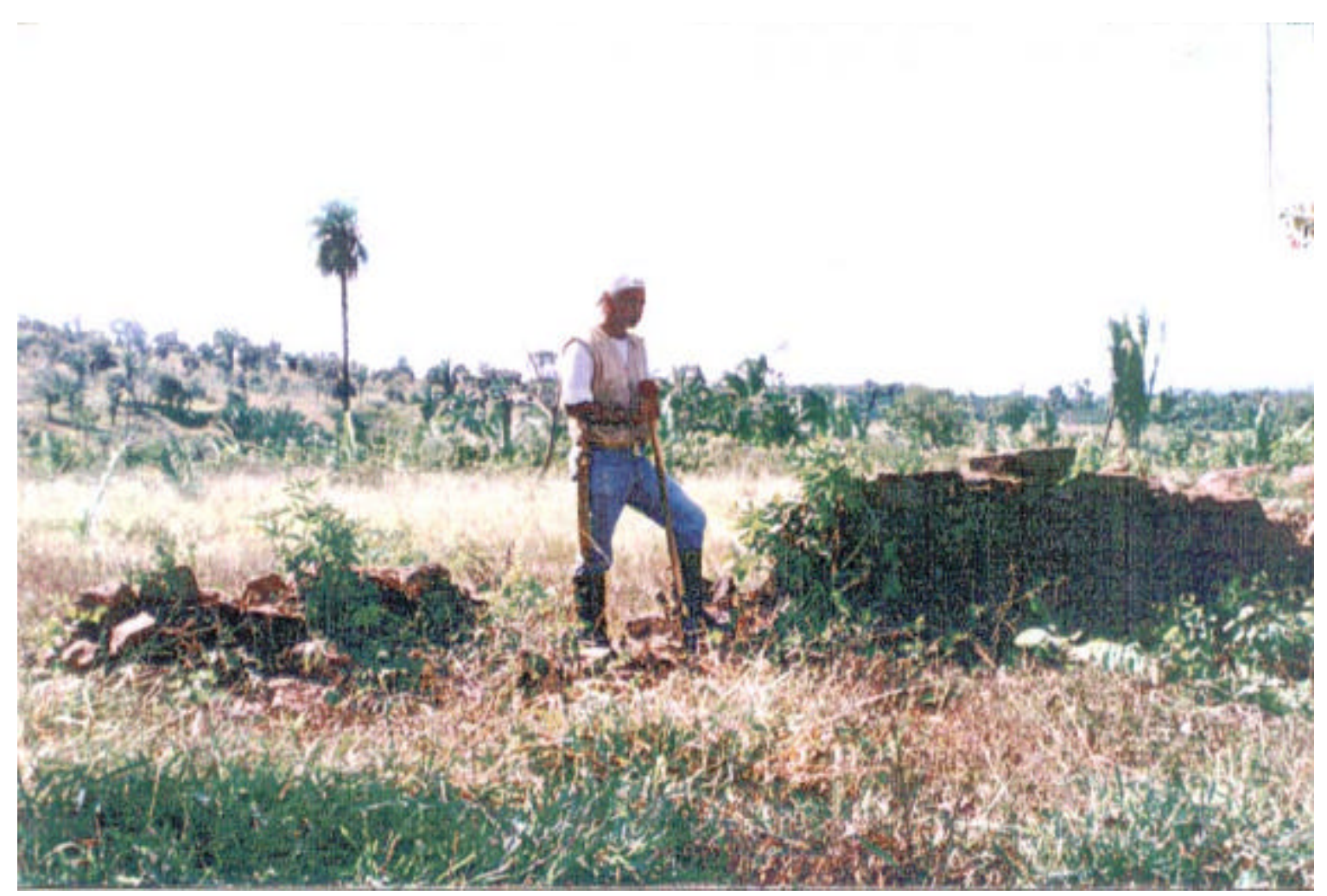

Foto 05: Tipo de depredação comum na região. Os monumentos são destruídos em busca de tesouros. (Foto: UFMG/Projeto de Salvamento Histórico-arqueológico na área da represa de Serra da Mesa). 


\title{
1.5. Lei CONAMA e Lei $95733 / 88$
}

\begin{abstract}
"A Lei do Conselho Nacional de Meio Ambiente - CONAMA de 1986, certamente é mais um instrumento de proteção, salvamento e mitigação do patrimônio arqueológico ameaçado. $O$ artigo $6^{\circ}$ estabelece a necessidade de estudos arqueológicos em consonância com as etapas de licenciamento ambiental de grandes empreendimentos econômicos, dentro do item sócioeconomia". ${ }^{36}$
\end{abstract}

O Decreto Federal de $n^{\circ}$ 95733, de 12 de fevereiro de 1988, dispõe que:

"Considerando que a execução de alguns projetos e a construção de obras federais podem causar impactos de natureza ambiental, cultural e social que exijam medidas corretivas por parte do Poder Público, envolvendo, em muitos casos, os Estados e os Municípios onde se situam esses empreendimentos;

(...) Considerando que a execução desses empreendimentos visa ao desenvolvimento, à melhoria das condições do meio e à elevação do nível de vida das comunidades envolvidas, não sendo justo que os reflexos negativos dela decorrentes causem efeitos contrários ao objetivado pelo Governo; (...); Decreta: Art. $1^{\circ}$ - No planejamento de projetos e obras de médio e grande porte executados total ou parcialmente com recursos federais, serão considerados os efeitos de caráter ambiental, cultural e social que esses empreendimentos possam causar ao meio considerado. (...)

Art. $2^{o}$ - Os projetos e as obras já em execução ou em planejamento, serão revistos para se adaptarem ao disposto no artigo anterior."

Mas, a preocupação de como preservar passa também pela definição do que será preservado. Não se pode preservar tudo, seja de natureza cultural ou ambiental. Tal fato implicaria impedir toda e qualquer intervenção modificativa do meio ambiente, o que significa dizer que se criaria uma situação em que o próprio processo cultural seria estático. Dessa forma, ao contrário do que se pretendia, que é a preservação de manifestações culturais passadas, estar-se-ia de fato impedindo que a cultura continuasse a se manifestar. 
"Por isto, a preservação do meio ambiente natural e cultural é feita pela individuação de bens que, de uma ou outra forma, tornam-se imprescindiveis para a manutenção do equilíbrio ambiental $^{37}$ ou sejam representativos, evocativos ou identificadores da história da sociedade humana e da cultura de um modo geral." 38

Ainda de acordo com o autor, todos os bens culturais ou ambientais podem ser classificados como públicos ou privados, sendo que os ambientais, mesmo quando são de propriedade privada, têm um caráter público, ou seja, os direitos sobre esses bens são exercidos com limitações e restrições. Surge, portanto, uma nova categoria de bens, que são os de interesse público. Dessa forma, toda a sociedade passa a ter sua quota de responsabilidade em relação à conservação e à preservação do Patrimônio Cultural e Ambiental em que está inserida. Cabe, portanto, à sociedade, criar ou exigir a criação de organismos e mecanismos encarregados de gerenciar e regulamentar os processos de preservação, bem como fiscalizar a eficiência das ações envolvidas nesse processo.

De qualquer forma, a legislação brasileira procura ser bem abrangente, e prevê " $a$ compatibilização do desenvolvimento econômico-social com a preservação da qualidade do meio ambiente e do equilíbrio ecológico" ${ }^{39}$, sendo entendido como meio-ambiente “o conjunto de condições, leis, influências e interações de ordem física, química e biológica, que permite, abriga e rege a vida em todas as suas formas”. Para tanto, a legislação brasileira está amparada em diversos organismos, tais como o CONAMA (Conselho Nacional do Meio Ambiente), o IBAMA (Instituto Brasileiro do Meio Ambiente e Recursos Naturais Renováveis), a Secretaria do Meio Ambiente da Presidência da República, o SPHAN (Secretaria do Patrimônio Histórico e Artístico Nacional), na ordem dos bens culturais e diversos órgãos de nível estadual.

\footnotetext{
${ }^{36}$ PAULA \& BAETA. Política patrimonial arqueológica no estado de Minas Gerais - alguns aspectos, O Carste, v.12, n.4, 2000, p.200.

${ }^{37}$ Equilíbrio ambiental, juridicamente, é a possibilidade de todas as espécies se reproduzirem e poderem se manter vivas. Quando uma espécie entra em risco de extinção, nos deparamos, juridicamente, com uma situação de desequilíbrio. In: SOUZA FILHO,1997, p.16.

${ }^{38}$ SOUZA FILHO. Bens culturais e proteção jurídica, 1997, p.16.
} 


\subsection{As Leis Estaduais}

Atualmente, quase todos os Estados brasileiros possuem uma legislação própria para a proteção do seu Patrimônio Cultural. Em muitos casos foram criados orgnismos estaduais cuja finalidade é instituir os serviços de proteção desse patrimônio, sendo que geralmente tomam como referência a legislação federal, com ligeiras modificações e adaptações .

A legislação do estado de Goiás está baseada na Lei $\mathrm{n}^{\circ}$ 8.915, de 13 de outubro de 1.980, e “dispõe sobre a proteção do Patrimônio Histórico e Artístico Estadual”. A lei cria um Conselho Consultivo do Patrimônio Histórico e Artístico Estadual, com poderes para decidir sobre o tombamento. A lei desde logo decide pelo tombamento de sete edificações e determina a inscrição no Livro do Tombo Estadual de todos os bens tombados ao nível federal, isto é, reconhece como integrantes do Patrimônio Cultural do Estado todos os bens que são referenciais para a Nação.

De acordo com Souza Filho ${ }^{40}$,

"é interessante observar que a maior parte dos estados faz uma adaptação do Decreto-Lei $n^{\circ} 25 / 37$, sem criar novos institutos ou mesmo novos métodos ou recursos para a proteção de seus bens culturais, salvo alguns, que criaram a iniciativa popular para o início do processo de tombamento, o que é, sem dúvida, uma novidade muito de acordo com o mais atual pensamento político e jurídico, que permeou a Constituição Federal vigente, inclusive com a criação da iniciativa popular no processo legislativo. Por outro lado, é curiosa a timidez de alguns estados no tombamento de bens federais, como o Pará e Sergipe, que renunciam mais que a uma competência, a um direito de seu povo. Esta renúncia, inclusive, é de duvidosa constitucionalidade" ${ }^{41}$.

Embora possam existir algumas contradições e muitas discussões sobre o exercício do poder público e as várias instâncias da proteção do Patrimônio Cultural, é ponto pacífico

\footnotetext{
${ }^{40}$ Lei Federal n ${ }^{\circ} 6938$ de 31 de Agosto de 1981, art. $4^{\circ}$.

${ }^{40}$ SOUZA FILHO. Bens culturais e proteção jurídica, 1997, p.88.

${ }^{41}$ Os Estados de Sergipe e Pará são os únicos que, dispondo de legislação própria, excluem a possibilidade de tombamento de bens de domínio da União..
} 


\begin{abstract}
"o entendimento de que as normas de proteção ambiental, nelas incluídas as protetoras do Patrimônio Cultural, são de direito público, e dizem respeito ao dever do Estado - em todas as instâncias do poder - proteger o interesse público de que se reveste esse Patrimônio. Além disso, e apesar de a doutrina em geral usar a expressão competência concorrente entre a União, estados e municípios para legislar sobre esta matéria, José Afonso da Silva esclarece que se trata de 'competência (ou dever) comum ou paralela, e não de competência concorrente, em sentido técnico, pois que o exercício dela por uma das entidades não exclui a da outra. Vale dizer, em hipótese nenhuma se torna competência exclusiva, " 42 .
\end{abstract}

No entanto, uma mesma área ou bem cultural pode-se tornar objeto de situações conflitantes, uma vez que existem as contradições entre as várias instâncias do poder público. Ocorre que no ato de definir o que será considerado relevante para ser objeto de uma política de preservação poderão ocorrer interesses divergentes, levando a adotar posturas contrárias, ou seja, um bem definido em instância federal como sendo um Patrimônio Cultural, poderá perfeitamente estar em consonância com o poder público estadual e municipal. O contrário, por sua vez, nem sempre ocorre, ou seja, um determinado bem pode ser considerado relevante pelo município e não o ser pelo poder público estadual e/ou pelo poder federal, criando assim uma situação por vezes incompatíveis. Para exemplificar o caso, Prudente de Morais Netto, citado por Souza Filho ${ }^{43}$, coloca que:

"Os critérios da avaliação estimativa, capaz de justificar o tombamento de um bem, variam, conforme se trate de apreciá-lo do ponto de vista da União, de um Estado ou de um Município, pois é evidente que haverá bens de irrecusável valor para um Município que não tenham a mesma significância para a União ou para o próprio Estado membro da Federação”.

Antes de tudo porém, não se pode esquecer que o Patrimônio Cultural é nacional quando é referência de cultura nacional; é estadual, quando se reporta à cultura estadual; municipal se a esta unidade se refere, ou ainda internacional se se compõe como patrimônio da humanidade, aceito pelo direito no Brasil, de acordo com a própria Constituição. "Trata-se

\footnotetext{
${ }^{42}$ SOUZA FILHO. Bens culturais e proteção jurídica, 1997, p.82.

${ }^{42}$ SOUZA FILHO. Bens culturais e proteção jurídica, 1997, p.83.
} 
de um Patrimônio da União que deverá ser protegido pelo estado e pelo município, de um Patrimônio estadual que deverá ser protegido pela União e pelo Estado." 44

De acordo com Arantes ${ }^{45}$,

"nesse complexo contexto de intervenção jurídicoadministrativa, econômica e arquitetônica, há que se aprofundar o conhecimento do processo de reelaboração (ou apropriação simbólica) que se dá no plano sociológico. Através de acréscimos de significado e transformações simbólicas, esses bens são como que recriados culturalmente pela 'preservação', passando a carregar consigo inclusive as marcas do processo que os transformou em 'bens do patrimônio' (separação do cotidiano, maior visibilidade, uma certa aura de importância e sacralidade, etc.)”.

\subsection{A Proteção Internacional}

A preocupação com a preservação de bens culturais no nível internacional surgiu, sobretudo, após a Segunda Guerra Mundial, quando se ampliou a cooperação entre os povos, visando, sobretudo, a coibir a apropriação indébita de bens culturais, fato comum até a primeira metade do século XX. Organismos como a ONU - Organização das Nações Unidas e a UNESCO - United Nations Educational, Scientic and Cultural Organization foram criados para efetivar a cooperação internacional.

Num mundo cada vez mais globalizado, em que os meios de comunicação atingem grande alcance, é fácil perceber que a cultura também se globaliza e se expande, à medida que elementos culturais penetram cada vez mais em sociedades distintas, levando de um para outro lado informações e valores diferentes, em velocidade cada vez mais rápida.

"Um dos graves problemas com que se defrontam os países no mundo moderno é a perda de identidade cultural, isto é, a

\footnotetext{
${ }^{44}$ SOUZA FILHO. Bens culturais e proteção jurídica, 1997, p.83.

${ }^{44}$ ARANTES. Documentos históricos, documentos de cultura, In: Revista do Patrimônio Histórico e Artístico Nacional, n. 22, 1987, p. 52.
} 
progressiva redução dos valores que lhes são próprios, de peculiaridades que lhes diferenciam as culturas. (...) $O$ fenômeno da perda de identidade pode variar de intensidade com que se manifesta, mas sua disseminação é universal. Faz-se sentir nos países importadores de tecnologia e também em países geradores dessa tecnologia. Assinala-se para os primeiros o risco suplementar dessa absorção se converter em dependência econômica.",46

Embora existam grupos que fazem absoluta questão de se manterem à margem desse processo, como é o caso dos muçulmanos, por exemplo, cuja "ocidentalização" consideram como extremamente prejudicial, uma vez que implica na descaracterização de seus valores mais sagrados, a grande maioria dos países e culturas estão atualmente interligados, nas mais diversas relações: econômicas, políticas, culturais, humanitárias, etc. Desta forma,

"a cultura chamada universal passa a ter elementos identificadores em quase todas as partes do mundo. Passam a existir bens culturais que fazem reconhecer uma cultura internacional, mundial, como é impropriamente chamada, e que pertence a toda humanidade, sem excluir ou impedir a continuidade das identidades nacionais, locais e populares" ${ }^{\prime 4}$.

É passível de se compreender, portanto, que existam bens culturais que possam interessar a várias comunidades internacionais, seja pela sua grandeza, seja pela sua expressividade, ou por qualquer outro motivo. De qualquer forma, em 16 de novembro de 1972, partindo do pressuposto de que alguns bens culturais poderiam interessar "universalmente", e portanto, deveriam ser protegidos pelo consórcio das nações, foi aprovada pela Décima Sétima Reunião da Conferência Geral da UNESCO a Convenção sobre a proteção do patrimônio mundial, cultural e natural, em que os bens considerados de interesse internacional são protegidos pelo próprio país detentor do bem e por uma força acima de cada nacionalidade individual, representada pela própria UNESCO.

Embora os bens culturais possam ser de interesse internacional, isto não autoriza ninguém a vender ou comprar antigüidades ou bens arqueológicos no mercado mundial, e por isso mesmo a UNESCO esteve reunida por duas vezes para tratar da questão - em 1964 e em

\footnotetext{
${ }^{46}$ MAGALHÃES. Bens Culturais: instrumento para um desenvolvimento harmonioso. In: Revista do Patrimônio histórico e artístico nacional, n. 20, 1984, p.40.

${ }^{47}$ SOUZA FILHO. Bens culturais e proteção jurídica, 1997, p.101.
} 
1970 - sendo que, nas duas ocasiões, mostra-se preocupada com a apropriação ilícita desses bens, e proíbe a exportação e importação de bens culturais móveis.

"É claro que o controle sobre bens móveis é muito mais difícil do que sobre os imóveis. A legislação brasileira, por exemplo, é muito severa em relação aos bens arqueológicos, mas sua aplicação é quase nenhuma, já que em qualquer cidade brasileira se pode comprar estes bens, sem restrição, e retirá-

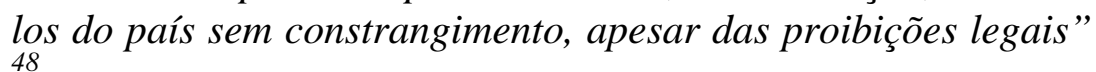
48 .

Mas ainda há que se discutir sobre a nacionalidade de um bem cultural, mesmo porque existe uma infinidade de objetos artísticos e culturais que já se encontram fora do seu país de origem - basta lembrar-se que até a primeira metade do século XX era absolutamente comum pesquisadores, cientistas, arqueólogos dos países europeus deslocarem-se para as mais diversas partes do mundo - e em larga escala para os países menos desenvolvidos - para realizarem suas pesquisas e escavações, cujo resultado material era invariavelmente transferido para os museus de seus respectivos países. Ora, tal fato suscita a questão relativa à nacionalidade desses bens culturais, e para legitimar essa questão, a UNESCO determinou, na Convenção de 1970 que "a nacionalidade de uma obra ou bem cultural, depende dela ter sido produzida no território nacional ou dela ter sido legitimamente adquirida. A legitimidade, no caso, é sempre dada pela autorização da autoridade competente"49. Neste caso, bens que já tenham sido transferidos de um país para outro com anuência das autoridades competentes estão em consonância com a legislação internacional.

A Convenção de 1970 também traz um dispositivo de grande importância para a preservação dos bens culturais que é a instituição do inventário como instrumento de caracterização da importância desses bens, bastando para isso o simples fato de constarem da listagem oficial. A Constituição Brasileira corrobora ao inventário esse papel, embora seja ainda pouco utilizado no Brasil. Através dele, é possível definir os bens culturais que serão considerados inalienáveis por cada estado, e portanto, ser vedada a sua venda e exportação.

\footnotetext{
${ }^{48}$ SOUZA FILHO. Bens culturais e proteção jurídica, 1997, p. 31.

${ }^{49}$ SOUZA FILHO. Bens culturais e proteção jurídica, 1997, p. 106
} 
Em 1972, a UNESCO estabeleceu a definição de Patrimônio Cultural da Humanidade, incluindo aí os bens culturais pertencentes ao Patrimônio Mundial. Nesta Convenção, os bens assim classificados passaram a ter a sua preservação obrigatória pelo Estado Membro, que se comprometia a preservá-los perante os demais Estados Membros da entidade. A partir de então, a preservação daqueles determinados bens deixou de ser um problema de economia doméstica e passou a tornar-se um compromisso internacional, havendo, para tanto, inclusive, auxílio financeiro advindo de um fundo, o Fundo do Patrimônio Mundial, que arrecada verbas para custear programas de restauração e proteção aos bens tombados.

"O primeiro artigo da Convenção define o que pode ser
considerado Patrimônio Cultural da Humanidade: 'los
monumentos: obras arquitetónicas, de escultura o de pinturas y
grupos de elementos, que tengam um valor universal y
excepcional desde el punto de vista de la historia, del arte o de
la ciencia; los conjuntos: grupos de construcciones, aisladas o
reunidas, cuya arquitetura, unidad e integración en el paisaje
les dé um valor excepcional desde el punto de vista de la
historia, del arte o de la ciencia; los lugares: obras del hombre
o obras conjuntas del hombre y de la naturaleza así como las
zonas, incluidos los lugares arqueológicos que tengam um valor
universal excepcional desde el punto de vista historico, estético,
etnológico o antropológico'. Nesta definição, saltam à vista
duas características comuns a todo Patrimônio Mundial: a
monumentalidade e excepcionalidade. Isto significa que a obra
deve chamar a atenção pelas suas dimensões, deve ser
grandiosa, monumental e, nâo ter paralelos, ser única,
exemplar, excepcional. Cada Estado nacional tem a obrigação,
contraída na própria convenção, de identificar, proteger,
conservar, reabilitar às gerações futuras o Patrimônio Cultural
e Natural situado em seu território. Baseado nesta obrigação, o
Estado se compromete a adotar uma política de proteção ao
Patrimônio Cultural e Natural, assim como criar órgãos oficiais
de proteção"5o.

Assim, possuir um Patrimônio Cultural da Humanidade, em seu território, confere ao Estado muito mais do que status junto à comunidade internacional, mas, sobretudo, conferelhe a obrigação de legislar e preservar esse patrimônio em prol do bem comum. De qualquer forma não é aleatoriamente que um bem passa a ser definido como Patrimônio Cultural da Humanidade. Para tanto é necessário que haja uma manifestação do Estado, e a aprovação da

\footnotetext{
${ }^{50}$ SOUZA FILHO. Bens culturais e proteção jurídica, 1997, p.108.
} 
indicação só ocorrerá com o consentimento do Estado interessado em inscrever um bem na Lista do Patrimônio Mundial, que corresponde a um registro. Dentro dessa lista há uma outra lista - a dos bens em perigo - que reúne todos os bens culturais ou naturais ameaçados por algum tipo de risco, e cuja salvaguarda exija cuidados especiais. Neste caso, entra o auxílio do já citado Fundo do Patrimônio Mundial.

No Brasil, muitos bens estão na lista do Patrimônio Mundial, entre eles: o Centro Histórico de Olinda (PE); as Missões Jesuíticas dos Guaranis (RS), em conjunto com a Argentina, a cidade de Ouro Preto (MG), o centro histórico de Salvador (Ba), o Plano Piloto de Brasília (DF), dentre outros.

Vários outros atos, acordos, convenções e recomendações foram produzidos ao longo do século XX, para tratar do Patrimônio Cultural no plano internacional, podendo, muitos destes acordos apresentarem amplitude regional, bilateral ou ainda multilateral. Listar todos eles seria tarefa árdua e injustificada, no entanto, pode-se ressaltar, de maneira simplificada, o teor de alguns destes acordos:

- Carta de Atenas. Documento resultante de conferência ralizada em outubro de 1931, em Atenas. Versa sobre a administração e legislação de monumentos históricos.

- Accordo de Firenz, de 1950, da UNESCO. Sua finalidade era ordenar as importações de objetos de caráter educativo, científico e cultural, com recomendação sobre a conservação dos bens culturais que a execução de obras públicas ou privadas possam pôr em perigo, ou seja, já havia a preocupação de se proteger bens ainda desconhecidos, como no caso da construção de usinas hidrelétricas, por exemplo.

- Recomendação de Nova Delhi. Trata-se de uma recomendação que define os princípios internacionais a serem aplicados em matéria de pesquisas arqueológicas, disposta em uma Conferência Geral das Nações Unidas, em Nova Delhi, em dezembro de 1956. 
- Recomendação de Paris. Resultante da Conferência Geral da Organização das Nações Unidas realizada em Paris, em dezembro de 1962, trata de recomendação relativa à salvaguarda da beleza, do caráter das paisagens e dos sítios que fazem parte do quadro natural, identificando estes elementos como pertencentes ao Patrimônio Cultural.

- O Tratado Union Panamericana .Assinado em Washington, em 1962, patrocinado pela OEA - Organização dos Estados Americanos, pretende definir diretrizes para a proteção dos bens culturais em território americano. Este tratado denomina de "monumentos móveis" os bens juridicamente protegidos.

- A Carta de Veneza. Aprovada pelo II Congresso Internacional de Arquitetura e de Técnicos de Monumentos Históricos, em Veneza, em 1964. Este documento trata da preservação e restauração de monumentos e sítios urbanos ou rurais, desde que sejam "testemunho de uma civilização particular, de uma evolução significativa ou de um acontecimento histórico”.

- Recomendação de Paris. Trata-se de um documento resultante da Conferência Geral Organização das Nações Unidas, realizada em novembro de 1964, em Paris, e apresenta recomendações sobre medidas destinadas a proibir e impedir a exportação, a importação e a transferência de propriedade ilícitas de bens culturais.

- Normas de Quito. Realizada pela OEA - Organização dos Estados Americanos no Equador em 1967. Dela resultou um conjunto de recomendações que trata de uma política geral de conservação e utilização de monumentos e lugares de interesse histórico e artístico, das quais o Brasil é também signatário.

- Recomendação de Paris. Documento elaborado a partir da Conferência Geral da Organização das Nações Unidas realizada em Paris em 1968, e trata da conservação dos bens culturais ameaçados pela execução de obras públicas ou privadas.

- Compromisso de Brasília. Trata-se de documento elaborado a partir do Primeiro Encontro dos Governadores de Estado, Secretários Estaduais da Área Cultural, Prefeitos de Municípios Interessados, Presidentes e Representantes de Instituições Culturais, realizado 
em Brasília, em abril de 1970, e procura ser um estudo complementar das medidas necessárias à defesa do Patrimônio Histórico e Artístico Nacional.

- Compromisso de Salvador. Trata-se de um documento complementar ao supra citado, sendo uma continuidade do primeiro encontro, agora realizado em Salvador com o apoio do Ministério da Educação e Cultura e do IPHAN - Instituto do Patrimônio Histórico e Artístico Nacional.

- Convenção de Paris. Documento elaborado a partir da $17^{\mathrm{a}}$ Conferência Geral da Organização das Nações Unidas/ UNESCO, realizada em Paris, em 1972, e versa sobre a salvaguarda do Patrimônio Mundial, Cultural e Natural; (proteção nacional e proteção internacional).

- Carta do Restauro. Através da circular no 117, de 6 de abril de 1972, o Ministério da Instrução Pública da Itália divulgou o Documento sobre Restauração de 1972, entre os diretores e chefes de institutos autônomos, para que se atenham, escrupulosa e obrigatoriamente, em todas as intervenções de restauração em qualquer obra de arte, às normas por ela estabelecidas.

- Declaração de Estocolmo. Trata-se de documento elaborado em junho de 1972, em Estocolmo, após Assembléia Geral das Nações Unidas, e propõe-se a estabelecer uma visão global e princípios comuns que sirvam de inspiração e orientação à humanidade para a preservação e melhoria do ambiente humano.

- Resolução de São Domingos. Em dezembro de 1974 a OEA realizou na cidade de São Domingos em Costa Rica, o Primeiro Seminário Interamericano Sobre Experiências na Conservação e Restauração do Patrimônio Monumental dos Períodos Colonial e Republicano, este documento procura apresentar propostas operativas para a defesa e preservação desse patrimônio. 
- Declaração de Amsterdã. O Congresso de Amsterdã foi o coroamento do Ano Europeu do Patrimônio Arquitetônico, 1975, e reuniu delegados vindos de toda parte da Europa. O Comitê de Ministros do Conselho da Europa elaborou a Carta Européia do Patrimônio Arquitetônico, em que reconhece que a arquitetura singular da Europa é patrimônio comum de todos os seus povos e afirma a intenção dos Estados-membros de cooperar entre si e com os outros países europeus para protegê-lo. Este Congresso também afirma que o patrimônio arquitetônico da Europa é parte integrante do patrimônio cultural do mundo inteiro. A Carta Européia do Patrimônio Arquitetônico foi solenemente promulgada no Congresso sobre o Patrimônio Arquitetônico Europeu, realizado em Amsterdã, naquele mesmo ano, a que compareceram mil delegados de 25 países europeus, dentre eles ministros, arquitetos, urbanistas, eleitos locais, funcionários e representantes de associações. A partir de então passa a ser conhecida como Manifesto de Amsterdã.

- Recomendação de Nairobi. É uma recomendação elaborada a partir da $19^{a}$ Sessão da Organização das Nações Unidas/UNESCO, realizada em Nairobi, em novembro de 1976, e trata da salvaguarda dos conjuntos históricos ou tradicionais e sua função na vida contemporânea.

- Carta de Machu Pichu. Documento elaborado a partir de um Encontro Internacional de Arquitetos, ocorrido em Machu Pichu, em dezembro de 1977 e procura atualizar as premissas da Carta de Atenas, elaborada em 1933. Busca estabelecer orientações sobre planejamento urbano considerando também o planejamento econômico, dando em ambos os casos um enfoque e amplitude mundiais.

- Carta de Burra. O ICOMOS - Conselho Internacional de Monumentos e Sítios - reuniuse na Austrália, em 1980, e elaborou a Carta de Burra, cujas orientações versam sobre conservação, preservação, restauração e reconstrução de bens culturais.

- Carta de Florença. Documento redigido pelo Comitê Internacional de Jardins e Sítios Históricos - ICOMOS/IFLA - e Conselho Internacional de Monumentos e Sítios - 
ICOMOS - em reunião em Florença, em maio de 1981, que procura normatizar a proteção dos jardins históricos ${ }^{51}$, visando a complementar a Carta de Veneza, neste particular.

- Declaração de Nairobi. A Assembléia Mundial dos Estados, reunida em Nairobi, em maio de 1982, a fim de comemorar o décimo aniversário da Conferência das nações Unidas sobre o Meio Ambiente Humano, ocorrida em Estocolmo, elaborou documento em que reconhece a necessidade urgente de intensificarem-se esforços em níveis global, regional e local de modo a proteger e melhorar o meio ambiente.

- Declaração de Tlaxcala. Realizou-se no México, em outubro de 1982, o Terceiro Colóquio Interamericano Sobre a Conservação do Patrimônio Monumental, que versou sobre o tema "Revitalização das Pequenas Aglomerações", realizado pelo Comitê Nacional do ICOMOS mexicano. O documento examina a atual situação da América em relação aos perigos que ameaçam o patrimônio arquitetônico e a ambiência das pequenas localidades, e faz algumas recomendações sobre o tema.

- Declaração do México: A Conferência Mundial Sobre as Políticas Culturais, realizada no México, em 1985, pelo ICOMOS - Conselho Internacional de Monumentos e Sítios elaborou a Declaração do México, que, procurando "contribuir efetivamente para a aproximação entre os povos e a melhor compreensão entre os homens ${ }^{~} 52$, elaborou alguns princípios sobre: Identidade cultural, desenvolvimento, patrimônio cultural, e cooperação internacional.

- Carta de Washington: Em 1986 foi realizado, nos Estados Unidos, uma reunião do ICOMOS - Conselho Internacional de Monumentos e Sítios, do qual resultou a Carta Internacional Para a Salvaguarda das Cidades Históricas, diante da preocupação daquela entidade com as perdas irreversíveis de caráter cultural, social e econômico ocorridas em cidades ou bairros históricos em todo o mundo.

\footnotetext{
${ }^{51}$ Um jardim histórico é "uma composição arquitetônica e vegetal que, do ponto de vista da história ou da arte, apresenta, um interesse público. Como tal é considerado monumento". Carta de Florença, Art. $1^{\circ}$ ${ }^{52}$ INSTITUTO DO PATRIMÔNIO HISTÓRICO E ARTÍSTICO NACIONAL - IPHAN (Brasil). Cartas Patrimoniais, 1985, p.311.
} 
- Carta de Petrópolis. Em 1987 foi realizado, em Petrópolis, o Primeiro Seminário Brasileiro Para a Preservação e Revitalização de Centros Históricos, em que foi elaborado um documento versando sobre o sítio histórico urbano - SHU - conceituado como sendo parte integrante de um contexto mais amplo, “já que toda cidade é um organismo histórico”.

- Carta de Cabo Frio: Em outubro de 1989, o Comitê Brasileiro do ICOMOS reuniu, em um seminário em Cabo Frio, arqueólogos, arquitetos, botânicos, historiadores, engenheiros e outros profissionais,. buscando homenagear o navegador Américo Vespúcio, por ocasião dos 500 anos do descobrimento da América. Redigiu-se a partir desse encontro a Carta de Cabo Frio, documento que trata do encontro de civilizações nas Américas, onde se destaca a preocupação com o defesa da identidade cultural americana e com o processo de preservação dos monumentos culturais aqui presentes.

- Carta do Rio: Elaborada a partir da Conferência Geral das Nações Unidas Sobre o Meio Ambiente e o Desenvolvimento, realizada no Rio de Janeiro em 1992 e busca estabelecer uma aliança mundial nova mediante a criação de novos níveis de cooperação entre os Estados para que se respeitem os interesses de todos e se proteja a integridade do sistema ambiental e de desenvolvimento mundial.

\section{O patrimônio cultural histórico e o pré-histórico}

De maneira geral define-se e distingue-se o Patrimônio Cultural Histórico do Patrimônio Cultural Pré-Histórico de acordo com a antiguidade dos vestígios em questão. Embora possam haver divergências quanto ao períodos analisados, de acordo com cada pesquisa, ou mesmo em função da orientação que os pesquisadores dão ao seu trabalho, o mais comum é considerar-se, para o continente americano, o período pré-histórico como sendo aquele correspondente à fase anterior à influência européia, ou seja, quando o território 
era ocupado apenas pelos grupos indígenas pré-coloniais, e o período histórico, como sendo aquele após o descobrimento.

Na formação acadêmica brasileira comum, desde os primeiros anos da vida escolar, aprende-se muito pouco sobre o Brasil, antes de 1.500. Não se tem mais que um conhecimento muito superficial sobre nossos antepassados. Por ocasião da comemoração dos 500 anos do descobrimento, no entanto, abriu-se um espaço maior para se discutir e divulgar o passado do país. Tanto na mídia como nos meios acadêmicos, muito se falou sobre o Brasil pré-histórico. Foram realizados seminários, exposições, conferências dando à população uma visão um pouco mais ampla, resgatando o fato de que o Brasil já existia, com aspectos culturais específicos das nações indígenas que aqui viviam.

De acordo com Edna Morley,

"o continente americano emergiu, para o europeu do século $X V I$, como um espaço incomensurável, habitado por 'homens e bichos estranhíssimos, outros que os europeus'. Para dominálo, mais que para entendê-lo, era necessário reduzi-lo a dimensões menos grandiosas, passíveis de explicação à luz do conhecimento seiscentista" ${ }^{, 53}$.

"Seja como for, e independentemente da antigüidade que se atribua aos primeiros habitantes de nosso território - 10, $20 \mathrm{ou}$ mesmo mais de 30 mil anos, como já se propôs para assentamentos do Piauí - tanto eles quanto os nativos com os quais entraram em contato os colonizadores, a partir do séc. $X V I$, constituem horizonte radicalmente distinto daquele que a colonização vai constituir. Como insiste Darcy Ribeiro (1978), os grupos indígenas historicamente conhecidos (e com maior razão os pré-coloniais) estão presentes em nossa história por exclusão" 54 .

De conformidade com a maioria dos autores ${ }^{55}$, também para o Projeto de Salvamento Histórico Arqueológico de Serra da Mesa no qual este trabalho está baseado, foi definido

\footnotetext{
${ }^{53}$ MORLEY. Fazer arqueologia: resgatar memórias, Revista do Patrimônio Histórico e Artístico Nacional., n. 22, 1987, p.212.

${ }^{54}$ MENESES, Identidade cultural e arqueologia, Revista do Patrimônio Histórico e Artístico Nacional, n.20, 1984, p.35 .

${ }^{55}$ Sobre o assunto ver Introdução à arqueologia histórica, de Charles Orser Jr., 1992.
} 
como sendo o período histórico no Brasil a fase pós influência européia. A própria ocupação do território onde está inserida a área de pesquisa somente se intensificou no período colonial brasileiro, com as investidas dos bandeirantes, em busca de ouro e pedras preciosas. Antes disso, a região era ocupada por nações indígenas diversas.

De qualquer forma, tanto as comunidades indígenas anteriores à ocupação européia quanto o colonizador europeu que desbravou o sertão goiano deixaram vestígios de sua ocupação. O trabalho realizado pelo Projeto de Salvamento Histórico Arqueológico de Serra da Mesa tinha por objetivo resgatar todos os vestígios possíveis dessa ocupação para o período histórico, na área onde seria construída a represa da Usina Hidrelétrica de Serra da Mesa. Para tanto, fazia-se necessário compreender, analisar e identificar quais seriam os tipos de vestígios passíveis de serem encontrados nessa região.

Primeiramente, deve-se buscar compreender que se trata de um trabalho de resgate da memória e da cultura de uma determinada área, uma vez que uma pequena parte da sua história estaria perdida, à medida que estes vestígios de ocupação se perdessem também. Dessa forma, o resgate dos vestígios possibilitariam perpetuar as marcas da ocupação da região em questão.

"É certo que a história da cultura de uma sociedade está, naturalmente, relacionada de modo direto à preservação de sua memória" ${ }^{56}$. Embora já se tenha dito que a definição do que preservar, em termos de memória e de bens culturais passa pela própria importância que determinados bens adquirem dentro da sociedade como um todo, outro fator que não deve ser esquecido é o fato de que, partindo do poder público, essa decisão será sempre representativa de uma parcela dessa sociedade. Segundo Durham ${ }^{57}$, "os monumentos que se conservam são aqueles que estão associados com os feitos e a produção cultural das classes dominantes. Raramente se preserva a história dos dominados."

Há que se ter cuidado para não se cair na tentação de ser simplista demais, tratando questão tão complexa de forma reducionista. No entanto, deve-se salientar que, de fato, aprende-se a valorizar as expressões culturais que sejam significativas. Partindo do

\footnotetext{
${ }^{56}$ MORLEY. Fazer arqueologia: resgatar memórias, Revista do Patrimônio Histórico e Artístico Nacional, n.20, 1984, p.213.

${ }^{57}$ DURHAM. Texto II. ,In: ARANTES. Produzindo o passado, 1987, p.33.
} 
pressuposto de que não se pode entender a cultura a não ser a partir de suas próprias expressões materiais, (sejam elas sob a forma de artefatos, obras de arte, conhecimentos adquiridos, etc.), deve-se levar em consideração que esses bens materiais só são significativos porque estão permeados de relações sociais, de significados e simbologias. Ora, é sabido que as relações sociais estão sempre emersas nas mais diferentes relações de poder: relações entre grupos, entre comunidades, entre indivíduos, em que sempre existirão segmentos dominados e segmentos dominadores, sendo que os últimos têm, em maior ou menor grau, a capacidade de controlar ou dirigir (ainda que de forma indireta) a produção material - e portanto, a produção cultural dos primeiros.

"O componente elitista da noção de cultura no senso comum também tem um lastro de verdade, na medida em que as classes dominantes são privilegiadas no sentido de terem os recursos, o tempo, o lazer e o treinamento para poder se apropriar dos bens culturais mais elaborados.

"As classes populares são privadas desses recursos e têm freqüentemente que produzir elas próprias os bens culturais para o seu consumo, de um modo muito mais difícil, muito mais empobrecido e muito menos cumulativo. A produção das camadas pobres não se arquiva e, portanto, uma vez produzida, pode ser rapidamente perdida. A memória popular é uma memória curta, exatamente porque depende da memória das pessoas." 58

Comungando deste ponto de vista, o arquiteto Jean-Bernard Perrin coloca que

"em matéria de proteção, voltamo-nos naturalmente em primeiro lugar para um testemunho glorioso do passado: o monumento histórico, artístico ou religioso, símbolo de luxo, de poderio e de cultura. A preservação, bem como a restauração desses monumentos, implicava em conhecimentos arqueológicos e tudo o que esses conhecimentos pressupõem: erudição, minúcia e respeito, mais pelo objeto em si do que pela cultura que ele ilustra" 59 .

\footnotetext{
${ }^{58}$ DURHAM. Texto II. In: ARANTES. Produzindo o passado, 1987, p.32.

${ }^{59}$ PERRIN.O exemplo francês de proteção, do remanejamento e da valorização do patrimônio histórico urbano. In: BRSIL. Secretaria do Patrimônio Histórico e Artístico Nacional. Restauração e revitalização de núcleos históricos: análise face à experiência francesa. 1980, p. 13.
} 
Ainda sobre o tema, Lemos adverte que, como a preservação e conservação dos bens culturais é de certa forma tendenciosa, registrando sobretudo o modo de viver das classes poderosas, ter-se-ia uma visão defasada da história local que se busca conservar, uma vez que os artefatos preservados não corresponderiam à realidade de fato.

"Em geral, guardaram-se os objetos e as construções ricas da classe poderosa. Guardaram-se os artefatos de exceção e perderam-se para todo o sempre os bens culturais usuais e corriqueiros do povo. Esses bens diferenciados preservados sempre podem levar a uma visão distorcida da memória coletiva, pois justamente por serem excepcionais não têm representatividade ${ }^{, 60}$.

Tendo o cuidado para não se criar uma visão romanceada das relações de classes, pode-se concluir, no entanto, sobre a grande importância dos projetos de salvamento das manifestações culturais histórica e pré-histórica para a área de Serra da Mesa. Uma extensa área foi inundada, e tudo o que não foi possível ser resgatado - em termos materiais - está irremediavelmente perdido. Portanto, a estratégia de salvamento fez-se necessária e urgente. A História da região e o seu processo de ocupação pode ser conhecido por qualquer pessoa, através dos livros e registros históricos. No entanto, os bens materiais resgatados ali são a expressão viva da cultura popular local. E, corroborando a idéia de Durhan acima, de fato, os bens materiais oriundos de uma comunidade menos favorecida é comprovadamente pequena.

$\mathrm{Na}$ realidade, em qualquer lugar do Brasil, as expressões materiais da sociedade escravista faz-se muito mais em função dos bens pertencentes à classe dos senhores do que à classe dos escravos. Estes não dispunham de bens materiais suficientes para deixarem amplos vestígios e quando os tinham eram bens de pouca resistência ao fator tempo.

"O historiador de arte, que se esmera em estudar os estilos, $e$ que provavelmente poderá dizer tudo sobre a riqueza de detalhes de uma igreja, pouco ou nada poderá nos informar a respeito das expressões culturais dos homens que viviam à sombra dos campanários daquelas construções. Como trabalhavam a terra, como inventavam seus artefatos a partir da matéria prima encontrada à sua volta, como adaptavam o instrumental importado às necessidades do cotidiano? Ao lado das faianças européias, as tigelas de barro aparecem grosseiras, na maioria das vezes despertando pouco interesse,

${ }^{60}$ LEMOS. O que é patrimônio histórico, 1985, p.22. 
embora fossem utilizadas em grande parte das casas brasileiras até o advento da industrialização" ${ }^{\text {. }}$.

Na região de estudo referente a este trabalho não foi encontrado grande variedade de objetos ou artefatos, mesmo porque se tratava de uma sociedade basicamente rural e pobre, do ponto de vista material. Mesmo aquela parcela da sociedade que era considerada abastada tinha pouca expressividade material, inclusive pela pouca gama de opções - oferecida pela época e pela localização interiorana da região - fato de grande relevância no período em questão, quando os meios de transportes se limitavam ao lombo dos burros tropeiros. Dessa forma, mesmo antes de se iniciarem os trabalhos de escavação, a equipe envolvida no Projeto não tinha grandes expectativas de encontrar vestígios de objetos finos, faianças, ou objetos de uso cotidiano comuns aos centros urbanos da época. Embora já se estivesse pesquisando o período colonial brasileiro, a característica mais marcante desta comunidade, constituída em pleno sertão goiano, era de uma total parcimônia - para não dizer limitação - de objetos de uso pessoal, sobretudo.

Com relação à pequena expressividade dos sítios e artefatos arqueológicos no Brasil, (e neste caso, refere-se tanto aos sítios pré-históricos quanto os históricos), Bezerra de Menezes coloca que

"nada temos de espetaculoso como nos Andes ou na Mesoamérica. É verdade que alguns tipos de sítio, como os sambaquis, apresentam certo interesse visual e alguns deles foram mesmo preservados para visitação . (...) Também no que diz respeito aos artefatos, podem ser feitas considerações comparáveis. Se há peças de interesse formal excepcional, como na cerâmica plástica ou pintada da Amazônia, nos muiraquitãs do Tapajós, nos zoólitos de concheiros do litoral meridional, a maioria é de extrema banalidade. Esta qualificação, do ponto de vista científico, não constitui demérito; pelo contrário, favorece o conhecimento de padrões em que é o banal, o corriqueiro, a série, e não o excepcional, que contam" ${ }^{62}$.

\footnotetext{
${ }^{61}$ MORLEY. Fazer arqueologia: resgatar memórias, Revista do Patrimônio Histórico e Artístico Nacional, n.22, 1987, p. 212.

${ }^{62}$ MENESES. Identidade cultural e arqueologia, Revista do Patrimônio Histórico e Artístico Nacional, n. 20, 1984 , p.35.
} 
O fato é que, de maneira geral, não se dá valor a vestígios que não sejam excepcionais, desde o tempo em que o Brasil foi descoberto do ponto de vista dos arqueólogos. Os achados de Peter Lund, em Lagoa Santa, no século XIX, levaram o mundo inteiro a voltar os olhos para o país, na esperança de vê-lo tornar-se um novo paraíso destes pesquisadores. (Recentemente, um grupo de pesquisadores da USP, financiados com verba internacional retomou as pesquisas em Lagoa Santa, buscando ampliar os conhecimentos sobre a ocupação da região, que, de acordo com os pesquisadores, remonta a 12 mil anos).

De qualquer forma não é a quantidade de vestígios de uma sociedade que a torna mais ou menos importante, nem mesmo a sua excepcionalidade, por si só. O elemento primordial é que estes bens têm como característica fundamental o fato de estarem vinculados a um determinado momento da história do Brasil, estando, portanto, articulados à memória de determinados grupos que, em seu conjunto, são constituintes da sociedade brasileira. Além disso, há que se relativizar o que os pesquisadores consideram comum, ou pouco expressivo. Ao se analisar o conjunto dos bens materiais resgatados das pesquisas arqueológicas, pode-se identificar peças de altíssima qualidade estética, sejam elas confeccionadas em pedra - como entre os povos da Amazônia e do litoral sul, ou em cerâmica - sobretudo a Tupiguarani e a Marajoara $^{63}$. Não se tem uma expressividade em monumentos ou em vestígios como os deixados pelas sociedades dos Incas, dos Maias ou dos Egípcios, por exemplo. De qualquer forma, isso não deveria ser motivo para uma desvalorização do nosso Patrimônio Cultural. O que podemos observar é que, corroborados pela idéia de que os vestígios materiais são pouco expressivos, acaba-se constituindo uma sociedade pouco compromissada com a preservação, e o que é pior, que não se valoriza o seu passado nem sua cultura material.

Há aí um grande problema. Se não se desenvolve uma consciência cultural, não se é capaz de construir um futuro com base no respeito pelo passado. Na verdade, isso só ocorrerá a partir do momento em que for possível conhecer melhor as manifestações culturais dos antepassados de forma mais ampla. Talvez até a questão da parcimônia dos vestígios materiais possa vir a ser minimizada ou erradicada. Como se conhece pouco, como se pode

\footnotetext{
${ }^{63}$ A cerâmica Tupiguarani é encontrada sobretudo na região sul e na maior parte do litoral brasileiro, até o Nordeste. Já a cerâmica amazônica é ainda muito pouco conhecida, principalmente devido às dificuldades de penetração na região. A fase Marajoara floresceu na grande ilha que se situa na foz do rio Amazonas, e foi datada entre os anos 400 e 1350 da nossa era.
} 
considerar, de antemão, que estas manifestações sejam realmente pobres? O que ocorre é que num país onde a educação e a cultura não se constituem prioridades governamentais, torna-se muito difícil desenvolver pesquisas abrangentes e consistentes, em uma área onde o fio condutor é exatamente o elemento cultural.

"Dentre os bens socioambientais destacam-se os culturais, ou históricos, artísticos, arqueológicos, etnográficos, paisagísticos, bibliográficos. Estes bens têm a característica de estarem vinculados a fatos da História do Brasil ou terem excepcional valor arqueológico, etnográfico, bibliográfico, artístico ou, ainda, serem portadores de referência à identidade, à ação, à memória dos diferentes grupos formadores $d a$ sociedade brasileira" ${ }^{64}$.

Conhecer estes bens de forma mais minuciosa, elaborar projetos de pesquisa em que os pesquisadores possam buscar as respostas para a relação entre estes bens e a sua importância dentro da formação do Brasil - mesmo antes da chegada do europeu - são caminhos fundamentais para se construir uma consciência cultural brasileira. Ocorre que não se está preparado para isto. Não há recursos materiais, nem recursos humanos suficientes; não há veículos de divulgação eficazes, nem uma fiscalização adequada, que seja capaz de fazer cumprir a legislação existente. É certo, que em termos arqueológicos, o progresso e a civilização são geralmente causadores de danos irreversíveis. Não raro, poucos meses após iniciada uma obra qualquer, ou uma exploração mineral, por exemplo, constata-se que, em poucos meses já não resta quase nada de bens - objetos, pinturas, sítios - que antes haviam estado ali por dezenas de séculos.

Cabe aqui lembrar que uma cultura é representada não apenas por bens materiais, mas também por aqueles que não têm materialidade, ou seja, bens imateriais ou intangíveis. De acordo com Souza Filho,

\footnotetext{
“os bens culturais materiais - móveis ou imóveis - só o são porque guardam uma evocação, representação, lembrança, quer dizer, por mais material que sejam, existe nos bens culturais uma parcela de imaterialidade, que é justamente o que os faz culturais. Assim, o valor cultural da obra de arte não está no material com o qual foi construída, mas no que a construção
}

\footnotetext{
${ }^{64}$ SOUZA FILHO. Bens culturais e proteção jurídica, 1997, p. 29.
} 
evoca, seja um estilo, um processo tecnológico ou um fato histórico. A última casa de adobe, é uma referência a um processo construtivo, portanto, cultural. Há bens culturais, porém, que não se revestem desta materialidade, porque não importa sua matéria-prima ou o suporte que as materializa, mas apenas a evocação ou representação que sugerem"65.

Muito embora os vestígios arqueológicos no Brasil possam ser considerados modestos, do ponto de vista material, não se deve desconsiderar que, de maneira geral, todos os povos que foram objeto de colonização por parte de nações ditas "mais civilizadas" sofreram um processo de anulação das manifestações indígenas. É interessante observar também que essa parcimônia dá -se sobretudo quando não se está lidando com as áreas urbanas mais expressivas, ou seja, quando se trata do sertão, uma vez que a própria forma de ocupação do território explica isso. Ainda de acordo com Morley,

"estabelece-se o português no Brasil com objetivos traçados no Reino e com modelos de apropriação inspirados em conquistas anteriores. Os primeiros assentamentos surgem como um amontoado de palhoças de pau-a-pique, cercadas por paliçadas sobre colinas, numa situação defensiva que os isola do meio circundante. Crescem desordenadas, tocam suas fronteiras primitivas e repartem-se em novas células periféricas que voltarão a unir-se, formando pouco a pouco núcleos maiores, mais condensados, encerrados em si mesmos $e$ dependentes. para sua sobrevivência, de uma economia desenvolvida para além de seus limites, o sertão. (...) Desse sertão pouco se sabe; exceto as incursões específicas terra adentro para prear índios ou buscar as minas, o português restringe-se à vida das cidades" ${ }^{6}$.

Conhecer os elementos históricos de uma dada região torna-se fundamental para iniciar-se qualquer trabalho de salvamento e/ou preservação do seu patrimônio histórico arqueológico. Faz-se necessário, portanto, analisar a forma de ocupação, os primeiros habitantes e os seus remanescentes. $O$ trabalho de busca dos vestígios ${ }^{67}$ é fundamental, uma

\footnotetext{
${ }^{65}$ SOUZA FILHO. Bens culturais e proteção jurídica, 1997, p.31.

${ }^{66}$ MORLEY. Fazer arqueologia: resgatar memórias, Revista do Patrimônio Histórico e Artístico Nacional, n.22, 1987, p. 212.

67 "Estes vestígios, mais tecnicamente, teriam que ser considerados como componentes da cultura material, isto é, aquele segmento do universo físico que é socialmente apropriado pelo homem e que engloba tanto objetos,
} 
vez que estes objetos constituem a expressão material da(s) cultura(s) que se busca conhecer. No entanto, há que se levar sempre em consideração as limitações das pesquisas, sobretudo quando elas se prestam muito mais a localizar e colecionar bens culturais do que a buscar respostas para compreender os processos sociais que os geraram. Assim,

"fica claro que seria extrema simplificação interpretar a ação preservacionista apenas como uma atividade técnica de organização intelectual de resíduos da história, redundando exclusivamente no salvamento e salvaguarda de objetos materiais, significativos por indicarem ou testemunharem eventos que se tenha resolvido eternizar" 68.

Volta-se, portanto, à questão levantada anteriormente. Muitas vezes, essa é uma opção do grupo de pesquisa. Se não for possível fazer um estudo mais amplo dos sítios em questão, que pelo menos eles possam ser registrados, de forma mais ampla e completa possível, garantindo também o seu registro junto ao IPHAN, para que ele possa estar sob a proteção judicial, em caso de vir a correr risco de destruição. Dessa forma, um mínimo já terá sido garantido, pelo menos até que surja uma oportunidade para que seja realizada uma pesquisa mais ampla e completa no local.

Deve-se deixar claro, no entanto, que há que se ter sempre o cuidado, em pesquisas arqueológicas, de não se criar uma situação que se configure como sendo puramente armazenadora de dados. Os artefatos por si só não serão suficientes para responderem às questões de ordem cultural. Na realidade, a identificação do patrimônio arqueológico é apenas o primeiro passo. No Brasil, há um número muito grande de sítios arqueológicos, sobretudo pré-históricos. Mas as condições brasileiras não facilitam o trabalho de pesquisa desses sítios. Além de um vastíssimo território, as pesquisas arqueológicas demandam uma complexidade de recursos materiais e humanos que em muitos casos inviabilizam ou, no mínimo, dificultam o trabalho. Nem mesmo o sensível desenvolvimento da arqueologia nos últimos anos foi suficiente para superar estas dificuldades.

utensílios, estruturas, como a natureza transformada em paisagem e todos os elementos bióticos e abióticos que integram um assentamento humano". (MENESES, 1984).

${ }^{68}$ ARANTES. Documentos históricos, documentos de cultura, Revista do Patrimônio Histórico e Artístico Nacional, n. 22, 1987, p.48. 
"A interpretação arqueológica, nessas circunstâncias, é de caráter eminentemente antropológico, fundamentada, porém, em evidências de várias naturezas que, para sua identificação, recuperação e organização, necessitam da intervenção de várias disciplinas (biociências, geociências, ciências exatas e tecnológicas) ${ }^{\prime 6}$.

Este foi o grande mérito do Projeto de Salvamento do Patrimônio Histórico Arqueológico de Serra da Mesa. Como a sua realização era urgente e fundamental para a continuidade da construção da Usina Hidrelétrica, ele pôde contar com um grande suporte financeiro, oferecido pela empresa contratante, no caso Furnas Centrais Elétricas, o que possibilitou a formação de uma equipe multidisciplinar e a dedicação em tempo integral ao trabalho, ou seja, ele pôde ocorrer durante os doze meses do ano, revezando os trabalhos em campo com as análises laboratoriais. (A pesquisa de Serra da Mesa será tema do nosso capítulo 3).

A pesquisa em Serra da Mesa fazia-se urgente devido à eminência de destruição em que os sítios se encontravam. Se não fosse esse o caso, com certeza uma pesquisa de tal envergadura não teria sido realizada ali, naquele momento, mesmo porque um outro elemento importante se coloca neste caso: o fato de que em geral, as pesquisas arqueológicas desconfiguram os sítios pesquisados, e, portanto, há que se considerar se esse custo é realmente justificável. O que vai determinar ou não a necessidade da sua realização será uma série de circunstâncias, analisáveis caso a caso. Isto ocorre porque em arqueologia, a noção de preservação torna-se relativa, já que o próprio processo de escavação, que é o seu principal instrumento, fundamental para se conhecer o verdadeiro potencial do sítio é ambíguo, porque, para recuperar as informações, há que se perder o suporte espacial, com perda, portanto, de carga documental, uma vez que descaracteriza totalmente o ambiente. No entanto, trata-se da única forma de se descobrir as formas de ocupação, a qualidade e a quantidade dos bens materiais e a cronologia de ocupação.

Se a pesquisa pode ser letal para o conjunto do sítio arqueológico, fica a questão: quando e por que ela deve ser realizada? Quais são os critérios que devem ser adotados na elaboração dos projetos de pesquisa? A formulação de critérios para o reconhecimento da

\footnotetext{
${ }^{69}$ MENESES. Para uma política arqueológica da SPHAN, Revista do Patrimônio Histórico e Artístico Nacional, n.22, 1987. p.207.
} 
relevância entre sítios e contextos é um fator que tem gerado grande polêmica. É inegável que em alguns casos, como em Serra da Mesa, não há o que se discutir. Naquela situação, todos os sítios dentro da área de inundação teriam que ter, em princípio, a mesma prioridade. Qualquer sítio que fosse relegado, a partir do momento em que a represa estivesse constituída estaria perdido para sempre, e, não tendo sido pesquisado, jamais se saberia exatamente o potencial que se teria perdido. De acordo com Meneses,

"naturalmente, haverá circunstâncias em que a pesquisa é impositiva . (...) penso, como exemplo, especialmente nos casos de prospecções arqueológicas (ou de preferência, verdadeiros projetos de investigação científica), nas áreas internas $e$ externas de monumentos ou conjuntos arquitetônicos e manchas urbanísticas. Tais operações, que normalmente caem no âmbito da arqueologia histórica, deveriam ser rotina sempre que houvesse intervenção com vistas à conservação ou restauração, ou equivalente. (...) Por isso, alguns autores, como L. Aten, propõem que a preservação arqueológica seja entendida como um sistema de triagem, isto é, um sistema de decisões de vida ou morte relativas a sítios, com vista a assegurar um número máximo de sobreviventes" 70 .

De qualquer forma, vale lembrar que para o Brasil, não existe na legislação nenhuma norma que defina as circunstâncias de prospecção e/ou salvamento dos sítios arqueológicos em detrimento de outros. Cabe ao IPHAN normatizar a pesquisa arqueológica, e o que a legislação prevê, de forma sucinta é:

1. Autorizações, para pesquisas de campo (prospecções, coletas de superfície, escavações sistemáticas).

2. Vistorias e avaliação de impactos de obras.

3. Autorizações e embargos de obras e intervenções em sítios arqueológicos.

4. Estudos e propostas de tombamento, preservação, restauração.

5. Definição das áreas de interesse arqueológico nos projetos de planejamento urbano e territorial.

6. Peritagem relativa a exportação, importação e circulação de material arqueológico.

\footnotetext{
${ }^{70}$ MENESES. Para uma política arqueológica da SPHAN, Revista do Patrimônio Histórico e Artístico Nacional, n.22, 1987, p.207.
} 
Decerto que a legislação brasileira não é cumprida à risca. Um sítio arqueológico pode vir a ser destruído sem que as autoridades tomem conhecimento, visto que não existe um trabalho constante de prospecção e catalogação de novos sítios por parte do Estado. Assim, se não for um sítio cadastrado, não existe como ele ser protegido a não ser que seja comunicada a sua descoberta pelo proprietário da área ou por alguém da comunidade. Se a área for de interesse econômico, o que ocorre com freqüência é que o sítio acaba sendo ignorado, em detrimento da atividade econômica (comumente mineração) que será instalada no local. Mesmo os sítios cadastrados não estão a salvo da destruição. Como o poder público e os órgãos encarregados do Patrimônio Cultural não dispõem de pessoal suficiente para realizar fiscalizações periódicas, é comum a depredação por turistas, por ignorância ou pelo interesse econômico.

\section{A importância do Patrimônio Cultural para a construção da identidade.}

Todo grupo ou comunidade apresenta aspectos culturais que lhes são próprios, singulares, e que os diferencia dos demais grupos. Tal característica constitui-se no que se denomina construção da cultura, ou seja, geração após geração, determinados valores, conhecimentos, técnicas, enfim, uma multiplicidade de tradições populares e de experiências vão sendo elaborados e transferidos às gerações futuras, dando individualidade e particularizando estas comunidades.

O conjunto de bens culturais desenvolvidos por uma determinada sociedade constituise no seu Patrimônio Cultural. O que une estes bens em um conjunto, formando o Patrimônio é justamente o reconhecimento de que são identificadores de uma determinada cultura, ou seja, através deles pode-se destacar traços culturais típicos de uma determinada comunidade. "É incomensurável o número total de bens que compõem o Patrimônio Cultural de um povo, de uma nação ou de um pequeno município", 71. 
O fato é que a cultura - com toda a abrangência do termo - se torna referência para os grupos sociais. $\mathrm{O}$ elemento diferenciador de um determinado grupo para outro é sempre um elemento cultural. Aprende-se desde cedo a analisar o mundo sob um próprio ponto de vista cultural, e por isso, torna-se cada vez mais difícil compreender aspectos culturais diferentes. No entanto, são estes aspectos que conferem identidade a cada um dos grupos, comunidades, sociedades, ou nações.

No mundo contemporâneo, passa-se por uma fase ambígua. De um lado vive-se um período marcado como nunca pelo avanço tecnológico e das comunicações. A chamada Nova Ordem Mundial prevê que, sobretudo no setor econômico e político, a globalização é o caminho mais claro, resultante de um reordenamento mundial em grandes blocos supranacionais. Por outro lado, e até como reação à globalização, o mundo observa aumentar cada vez mais os movimentos de regionalização, de reavivamento cultural e de repúdio à supremacia dos Estados capitalistas desenvolvidos, representantes dessa Nova Ordem Mundial. Em casos extremos, o culto pela própria cultura gera movimentos agressivos ao que é novo, ou aos seus representantes. Alguns grupos fecham-se em suas tradições seculares, buscando uma volta ao passado - ou a manutenção dele, através da preservação de certos valores e manifestações culturais, muitas vezes de difícil compreensão para os olhos ocidentais. Na esteira da intolerância cultural vem o xenofobismo e o racismo, práticas cada vez mais comuns, mesmo (ou sobretudo), em países ditos desenvolvidos. Neles, grupos organizam-se para reivindicar a supremacia racial ou cultural sobre as demais comunidades, principalmente quando se sentem ameaçados pela "contaminação cultural" dentro de seu próprio território. Dessa forma, pode-se considerar, de acordo com Regina Simões Lopes que

"conceituar cultura nos tempos que correm é tarefa delicada e perigosa. As definições tendem a uma abrangência cada vez maior, num mundo tornado pequeno para conter tantos canais de comunicação, logo interferências. As chamadas interferências culturais passam, então, a desempenhar um papel significativo na identificação do indivíduo, da região ou do país, sendo o seguro contra a despersonalização, elemento fundamental de resistência ao massacre do particular pela cultura de massas. Na busca dessas referências, vai-se

\footnotetext{
${ }^{71}$ LEMOS. O que é patrimônio Histórico, 1985, p. 12
} 
ampliando o conceito de cultura e atribuindo-se-lhe a função de salvaguarda da dignidade humana" 72 .

Assim é que cultura e identidade se casam. A cultura é o elemento primordial para dar identidade a um determinado grupo social, desde a pré-história até os dias de hoje. É por isso que se associa cultura ao ser humano e por extensão à Humanidade. Grupos de animais, por mais organizados que sejam, não chegam a estabelecer aspectos culturais entre si. A cultura passa a ser um fator inerente e simbólico da própria condição humana. Sendo assim, não cabe ao Estado nem a grupos distintos definir ou decidir o que serve e o que não serve como padrão cultural. A cultura é construída, e para tanto o fator tempo é elemento essencial. Não há certo nem errado, melhor ou pior. O que existem são diferenças, e como tal, as manifestações culturais são as mais variadas possíveis. "A atual preocupação com a chamada identidade cultural será, provavelmente, o reflexo da angústia individual, que leva o homem à busca de referências" 73 .

Segue-se a essa reflexão um outro aspecto importante. Se a identidade cultural é um elemento chave dentro de qualquer cultura, justifica-se a preocupação com a preservação das manifestações culturais - nos seus mais variados aspectos - como forma de preservação da segunda e afirmação da primeira; portanto, a elaboração de políticas de conservação do Patrimônio Cultural são por demais importantes em qualquer cultura.

Vários autores discutem a questão da formação cultural do Brasil - cujas origens mesclam variadas raças e culturas - e a busca da modernidade, como forma de ansiar sua inserção no mundo desenvolvido, o que o levaria a negligenciar ou, no mínimo, obscurecer a busca pela sua identidade cultural legítima. Para Maria Célia Paoli,

"isto aponta claramente para uma sociedade destituída de cidadania, em seu sentido pleno, se por esta palavra entendermos a formação, informação e participação múltiplas na construção da cultura, da política, de um espaço e de um tempo coletivos. Embora o Brasil não seja o único caso conhecido, parece claro que aqui a história não teve um papel formador de identidades" 74 .

\footnotetext{
${ }^{72}$ LOPES. A propósito de política cultural, Revista do Patrimônio Histórico e Artístico Nacional, n. 22, 1987, p. 26.

${ }^{73}$ LOPES. A propósito de política cultural, Revista do Patrimônio Histórico e Artístico Nacional, n. 22 , 1987, p. 27.

${ }^{74}$ PAOLI. Memória, história e cidadania: o direito ao passado., in: CUNHA. O direito à memória, 1992, p.26.
} 
Já Durham vai mais longe: para ela, a chamada identidade nacional não está devidamente caracterizada, uma vez que "nós nos identificamos pelo novo, em vez de nos identificarmos pelo passado" 75 .

Para outros autores, em muitos casos, prefere-se ignorar a identidade cultural quando se percebe que ela está ligada a condições ou situações que não se remetem a uma posição de destaque. Assim é que é negligenciada a formação cultural indígena e africana e ressalta-se as origens européias, por exemplo. Ou, segundo Serra,

"preferimos homenagear o Duque de Caxias, que é um militar de expressão mínima em relação a Zumbi. (...) É o caso de Zumbi. É o caso de Palmares. É uma história que nós só temos por que nos orgulharmos dela, e ninguém conhece. É propositadamente sepultada no esquecimento" ${ }^{76}$.

A discussão poderia se estender bem mais. De qualquer forma, o que se concretiza dela é que de fato a identidade cultural de uma nação não segue nenhum modelo ou padrão imposto por ninguém. Nem mesmo tem que ser necessariamente homogênea, sobretudo em um país de vastíssima extensão territorial como é o caso do Brasil, e que ademais, como já se viu, constituiu-se a partir de variadas raças e culturas. Alie-se a isso o fato de que se trata de um país realmente jovem, onde os supostos 500 anos de história não se constituem em 500 anos de expressão cultural livre. No mínimo, até a oficialização da independência política, esteve-se sob o estigma da dominação cultural aliada à dominação política. Após a emancipação, passa-se por consecutivos processos de aculturamento, sobretudo na busca incessante da modernidade, da inserção no mundo civilizado e desenvolvido. No momento atual, em que o mundo globalizado imprime características tão contraditórias como já se conhece, observa-se que a possibilidade de se manter uma coerência cultural torna-se efetivamente difícil. Portanto, resgatar a memória cultural brasileira é um passo importante para se conhecer melhor as expressões culturais em outras épocas e em comunidades pouco conhecidas. A soma dessas expressões culturais diferentes contribuirão para a formação da verdadeira identidade cultural do Brasil. Torna-se necessário compreender que o mosaico que constitui a sua cultura não é necessariamente um fato negativo, mas antes de tudo um fato

${ }^{75}$ DURHAM. Cultura, patrimônio e preservação. In: ARANTES. Produzindo o passado, 1987, p.52. 
peculiar. Como bem colocou Serra citando o professor Aloísio Magalhães, que dizia "que a realidade brasileira escondia riquezas debaixo de um tapete que era importante levantar, desvelar essas riquezas" . Compreendido isso, pode-se compreender que cultura não é um processo estanque nem fechado, mas antes de tudo troca e assimilação. Todas as culturas fazem parte do patrimônio comum da Humanidade. A identidade cultural de um povo se renova e enriquece em contato com as manifestações culturais dos demais.

Daí a grande importância de Projetos como o de Serra da Mesa,. oportunidade única de se conhecer um pouco melhor uma região tão pouco explorada cientificamente dentro do conjunto do território brasileiro, onde o processo de ocupação é relativamente recente e os vestígios culturais eram uma incógnita até a época da pesquisa. Diante da ocupação recente e das mudanças drásticas porque vem passando o espaço do sertão goiano, compreende-se que a preservação da cultura histórica regional é essencial para a manutenção ou a criação de um modo de vida que permita ao homem encontrar sua identidade e experimentar um sentimento de segurança face às mutações aceleradas da sociedade moderna.

"A identidade cultural é uma riqueza que dinamiza as possibilidades de realização da espécie humana ao mobilizar cada povo e cada grupo a nutrir-se de seu passado e acolher as contribuições externas compatíveis com a sua especificidade e continuar, assim, o processo de sua própria criação" ${ }^{77}$.

As mudanças recentes ocorridas no sertão goiano estão relacionadas ao surto de desenvolvimento e ampliação da fronteira agrícola em direção ao Centro-Oeste, que tem-se acelerado nos últimos anos. Devido a esse novo processo de ocupação, a região tem sofrido uma reorganização, com a implantação de grandes unidades rurais produtoras de cereais sobretudo soja - voltados para outro mercado que não o regional. Dessa forma, pode-se dizer, em uma breve análise, que o novo surto de ocupação traz um certo grau de desenvolvimento regional, visto que dinamiza a rede de transportes, gera algum emprego (ainda que em pequena escala), embora apresente também o outro lado: propriedades menores vão sendo incorporadas a esse novo processo produtivo, a agricultura e a pecuária de subsistência vão perdendo espaço e o trabalhador rural passa a um papel de dependência econômica maior do que no período anterior.

\footnotetext{
${ }^{76}$ SERRA. Questões de identidade cultural. In: ARANTES. Produzindo o passado, 1987, p.111.

${ }^{77}$ INSTITUTO DO PATRIMÔNIO HISTÓRICO E ARTÍSTICO NACIONAL - IPHAN (Brasil). Cartas patrimoniais, 1995, p.312.
} 
De qualquer forma as mudanças já estavam em curso, e reverter o processo não era possível. Assim, a usina de Serra da Mesa vem dinamizar - ainda que temporariamente - a economia regional, gerando grande número de empregos e incrementando o comércio, com aporte de grande número de novos consumidores nas cidades locais. Além disso, gerou uma expectativa positiva com relação ao futuro, quanto à possibilidade de um maior desenvolvimento a partir da entrada da operação da usina e da disponibilização de energia. Desenvolvimento econômico no entanto não significa, nem pode significar descaso ou destruição das manifestações culturais locais. É fundamental conciliar desenvolvimento econômico e qualidade de vida, o que, cada vez mais, as sociedades procuram, com maior ênfase, alcançar. É preciso crescer economicamente sem agredir o meio ambiente, sem destruir manifestações culturais, sem desprezar a cultura local. É indispensável promover o desenvolvimento para o ser humano, observando a capacidade dos indivíduos de aprender, de trocar experiências e, acima de tudo, de alcançar a sua plena realização individual e coletiva, visando ao bem comum.

"A cultura constitui uma dimensão fundamental do processo de desenvolvimento e contribui para fortalecer a independência, a soberania e a identidade das nações. O crescimento tem sido concebido freqüentemente em termos quantitativos, sem levar em conta a sua necessária dimensão qualitativa, ou seja, a satisfação das aspirações espirituais e culturais do homem. $O$ desenvolvimento autêntico persegue o bem-estar e a satisfação constantes de cada um e de todos" ${ }^{, 78}$.

Buscar-se-á, nos próximos capítulos, compreender melhor o trabalho desenvolvido em Serra da Mesa para se avaliar se foi possível atingir, ainda que em pequena escala, este objetivo maior, que é justamente permitir a manutenção das manifestações culturais da comunidade face ao progresso econômico instalado.

Numa primeira reflexão, já se pode verificar que sempre se deve prestar atenção às relações necessárias que existem entre o meio ambiente, o saber e o artefato, entre o artefato; e o homem, entre o homem e a natureza. Assim, um objeto isolado de seu contexto deve ser entendido como um fragmento, ou um segmento, de uma ampla urdidura de dependências e

\footnotetext{
${ }^{78}$ INSTITUTO DO PATRIMÔNIO HISTÓRICO E ARTÍSTICO NACIONAL - IPHAN (Brasil) Cartas Patrimoniais, 1995, p.313.
} 
entrelaçamentos de necessidades e interesses satisfeitos dentro das possibilidades locais da sociedade a que ele pertence ou pertenceu. 


\section{CAPÍTULO II}

\section{A GEOGRAFIA, O PATRIMÔNIO CULTURAL E A PAISAGEM}

"Os intelectuais interessados nos lugares e nas paisagens valorizadas não pretendem produzir apenas uma simples divagação poética sobre eles. O que está em questão são os sentimentos de indiferença, de afeição ou de aversão do homem pelos lugares com os quais tem alguma forma de contato. Sentimentos e valores que, seguramente, têm papel importante (em muitos casos, decisivos) na formação de juízos de valor, de atitudes e, em última análise de ações sobre esses lugares e paisagens." 


\section{A GEOGRAFIA, O PATRIMÔNIO CULTURAL E A PAISAGEM}

"Mais do que a Física ou a Fisiologia, que a Psicologia ou a Política, a Geografia observa e analisa aspectos do meio ambiente na escala e nas categorias em que comumente são apreendidos na vida diária. Por mais que os metodologistas pensem em como a Geografia deve ser, o temperamento de seus praticantes a faz universal e multifacetada. Em sua amplitude de interesses e capacidades - concreta e abstrata, acadêmica e prática, analítica e sintética, interna e externa, histórica e contemporânea, física e social, os geógrafos geralmente refletem o homem..."79

Uma pesquisa geográfica é sempre um desafio. O papel do geógrafo já foi discutido e analisado nas mais diversas instâncias, e o que se analisa, neste caso, é que não existe consenso. A extensão e abrangência da ciência geográfica é causa e efeito de muitas e inúmeras discussões dentro dos meios acadêmicos, sendo os pontos de vista os mais variados possíveis. De acordo com Vesentini ${ }^{80}$,

"um dos mais velhos e irresolvidos problemas da ciência geográfica diz respeito à dicotomia entre geografia física $e$ humana, entre o estudo geográfico da natureza e da sociedade.

\footnotetext{
${ }^{79}$ LOWENTHAL, citado por SANTOS. Projetos hidrelétricos de grande porte e efeitos sociais: o exemplo do topocídio provocado pela barragem de Porto Primavera, 1998, p.5.

${ }^{80}$ VESENTINI.Geografia, natureza e sociedade, 1997, p. 9
} 
"Para os clássicos em geral, a geografia seria uma ciência de síntese, de união entre a natureza e o homem, de estudo das relações do social com o seu meio ambiente. A própria polêmica sobre essa questão, sempre retomada, indicanos claramente que essa promessa epistemológica ficou na teoria, que a diferenciação entre essas duas modalidades da geografia sempre foi enorme, tendendo a se aprofundar cada vez mais nos dias atuais."

À questão some-se o fato de que, além da pluralidade de abordagens, existe ainda uma pluralidade de especialistas tratando de fazer análises que seriam próprias aos geógrafos. Não que a interdisciplinariedade não seja um bom caminho. O problema é que, quando não se consegue alinhavar os elementos variados sob um enfoque interdisciplinar, alcança-se no máximo uma análise multidisciplinar. Andrade ${ }^{81}$ coloca que

"o problema espacial é uma preocupação dos cientistas sociais das mais diversas formações, face às implicações sociológicas, antropológicas, históricas, econômicas, políticas, jurídicas e não apenas geográficas, que dão forma e conteúdo aos espaços produzidos pelo homem."

Assim, a Geografia, enquanto ciência que trata do espaço e das relações estabelecidas entre o homem e o meio, presta-se como instrumento de análise para as abordagens que procuram considerar os elementos naturais e a construção da cultura.

"Desde que a natureza é uma natureza humanizada, a explicação não é física, mas social. A geografia deixa de ser uma parte da física, uma filosofia da natureza, para ser uma filosofia das técnicas. As técnicas são aqui consideradas como o conjunto de meios de toda espécie de que o homem dispõe, em um dado momento, e dentro de uma organização social, econômica e política, para modificar a natureza, seja a natureza virgem, seja a natureza já alterada pelas gerações anteriores, 82 .

Modificar a natureza tem sido o papel da humanidade desde que ela surgiu na superfície do planeta. Incessantemente tem-se buscado modificar e modelar o espaço em função de nossas próprias necessidades e desejos das pessoas. E quanto mais se desenvolve tecnologicamente,

\footnotetext{
${ }^{81}$ ANDRADE. Populismo e organização social do espaço, Revista Geografia e Ensino, n 8, 1988, p.47.

${ }^{82}$ SANTOS.O espaço geográfico como categoria filosófica. Terra Livre, n.5, 1988, p.10.
} 
mais rapidamente se processam essas alterações. Dessa forma, a natureza intocada, constituinte do que se denomina como paisagem natural ou virgem, já não existe mais. Todos os ecossistemas são hoje passíveis de interferência humana, em maior ou menor grau, direta ou indiretamente. Enquanto agentes modeladores da natureza, os homens são relativamente jovens na história da terra.

"A ação humana tende a transformar o meio natural em meio geográfico, isto é, em meio moldado pela intervenção do homem no decurso da história. Temos aí um fato recente na história do mundo. Com efeito, embora a paleontologia nos informe sobre o aparecimento de seres que podemos considerar como tendo sido os primeiros homens, ocorrido há dois milhões de anos na África oriental, o papel do homem como agente de intervenção no espaço geográfico data apenas de há 6500 ou 7000 anos, com os primórdios da agricultura. A generalização da agricultura produziu-se em diversas regiões do globo, há três ou quatro milênios. Contudo, a ação humana tem se manifestado de maneira cada vez mais intensa, graças aos efeitos conjugados do crescimento demográfico em todo o mundo e do progresso das técnicas. De modo que, esta tênue película que é a história humana com relação à espessura da história do mundo ocupa não obstante um lugar de importância capital para a compreensão e para a explicação do espaço geográfico" ${ }^{, 83}$.

Além disso, a forma de apropriar-se da natureza é essencialmente cultural. As relações que grupos humanos diferentes têm para com a natureza estão sempre ligadas à sua própria formação cultural. Assim é que a forma de apropriação da natureza por uma sociedade capitalista ocidental é completamente diferente daquela de uma sociedade indígena, formada por caçadores-coletores no interior da Amazônia, por exemplo. Daí a construção de paisagens diferenciadas, não apenas pelo olhar de quem observa - o que é um fato - mas, sobretudo, pela forma de ocupação, que podem ser as mais variadas possíveis, o que leva, portanto, a compreender que um mesmo meio natural pode oferecer uma série de paisagens diferentes. $\mathrm{O}$ elemento chave que, em última instância, vai determinar a forma de ocupação, ou melhor, de exploração de um determinado meio, é justamente a oferta de recursos naturais passíveis de

${ }^{83}$ DOLLFUS. O espaço geográfico, 1982, p.29. 
exploração. O domínio da Natureza é, portanto, fundamental sob este ponto de vista. Vesentini $^{84}$, coloca que

"a atual 'crise ecológica' nos mostra que há um desequilíbrio nas relações entre sociedade moderna e natureza, $e$ a inquirição da origem desse fato nos conduz a uma concepção de natureza enquanto recurso, o que ocorreu na 'revolução' tecno-científica' dos séculos XVI e XVII. (Acontecimento, é bom ressaltar, interligado ao desenvolvimento do capitalismo e à ocidentalização de praticamente todo o planeta.)”

É interessante observar, no entanto, que os recursos naturais de um espaço qualquer só adquirem valor em função da sociedade que os explora, ou seja, só adquirem importância econômica a partir do tipo de exploração que será determinada.

"A noção de recursos naturais propõe de maneira falsa a questão das relações entre o homem e o meio. Como sabemos, não existe recurso em termos absolutos: um 'recurso' só é utilizável com relação a um certo nível de desenvolvimento técnico e à situação geográfica de um espaço. Há um século, uma mina de urânio não representava um recurso, o qual, entretanto também pode perder sua utilidade e sua significação. (...) De acordo com as épocas e com as técnicas, um mesmo recurso oferece possibilidades diferentes de utilização." ${ }^{85}$.

O certo é que da apropriação desses recursos nasce a capacidade de as sociedades se desenvolverem, o que se expressa através de várias formas, dentre elas, a expressão de sua arte e de sua cultura. Num sentido mais amplo, toda manifestação será considerada como sendo cultural. A grande questão reside em conseguir o desenvolvimento social com um comprometimento cada vez menor do meio ambiente, ou seja, a nova meta é buscar o chamado desenvolvimento sustentável. Esta expressão ganhou notoriedade possivelmente por ter sido adotada em importantes documentos como a Estratégia Mundial Para a Conservação, o informe Nosso Futuro Comum, da Comissão Brundtland (ONU, 1987), e o Informe da Comissão de Desenvolvimento e Meio Ambiente da América Latina e Caribe (1991).

\footnotetext{
${ }^{84}$ VESENTINI. Geografia, natureza e sociedade, 1997, p.10.

${ }^{85}$ DOLLFUS. O espaço geográfico, 1982, p. 38.
} 
A definição de desenvolvimento sustentável mais conhecida é o da Comissão Brundtland (Nosso Futuro Comum, 1987): é aquele que satisfaz as necessidades do presente sem comprometer a possibilidade das gerações futuras satisfazerem as suas. No capítulo dois do referido relatório afirma-se que o desenvolvimento sustentado baseia-se em dois conceitos chaves: a prioridade na satisfação das necessidades das camadas mais pobres da população, e as limitações que o estado atual da tecnologia e da organização social impõe ao meio ambiente.

“Um respaldo é certamente encontrado no conceito de ecodesenvolvimento, proposto por I. Sachs, que preconiza um crescimento capaz de conciliar processo econômico, justiça social e 'prudência' ecológica, visando à preservação de recursos renováveis e não renováveis (...) Papel relevante é atribuído à implementação de um processo econômico qualitativamente distinto dos modelos até então implantados em países subdesenvolvidos. Processo esse capaz de prescindir de tecnologias importadas que provocam impacto negativo sobre recursos naturais vulneráveis, e capaz de produzir um melhor equacionamento das desigualdades sociais" 86

$\mathrm{Na}$ atualidade tem se discutido muito o papel do geógrafo. Sobretudo quando se vive um momento histórico tão importante, com inúmeras mudanças ocorrendo de forma acelerada e transformando o mundo com uma rapidez que nem sempre se é capaz de assimilar. $\mathrm{Na}$ virada do século nos depara-se com um mundo dinâmico do ponto de vista das telecomunicações; globalizado, do ponto de vista econômico; desigual, do ponto de vista político e excludente, do ponto de vista social. Cabe ao geógrafo trabalhar com todas essas realidades, ordenar essas informações, analisá-las com neutralidade e buscar caminhos e direções para a construção de uma realidade mais justa.

Neste estudo, busca-se compreender como a Geografia e a paisagem, seu elemento de análise por natureza, inserem-se no contexto das sociedades como Patrimônio Cultural. Para tanto, observem-se alguns conceitos de paisagem, dentro da visão de diversos estudiosos do tema. Para Bertrand ${ }^{87}$,

\footnotetext{
${ }^{86}$ DAVIDOVICH. A propósito da Eco-Urb's 92: a temática urbana na questão ambiental. Geografia e Questão Ambiental, 1993, p. 14.

${ }^{87}$ BERTRAND. Paisagem e geografia física global - esboço metodológico. Caderno de Ciências da Terra , n.13, 1971, p. 23.
} 
"paisagem é um termo pouco usado e impreciso, e por isto mesmo, cômodo, que cada um utiliza a seu bel-prazer, na maior parte das vezes anexando um qualitativo de restrição que altera seu sentido (paisagem vegetal, por exemplo)".

Bertrand considera que o problema é de origem epistemológica e que o conceito de paisagem ficou quase estranho à Geografia Física moderna, não tendo suscitado nenhum estudo adequado. Considera também que a noção de escala é inseparável do estudo das paisagens.

Já o paisagista Burle Marx ${ }^{88}$, citado por Machado, coloca que há necessidade de se examinar os diversos sentidos da palavra paisagem, e apresenta as seguintes reflexões:

"O que é constante nelas é a referência ao sentido da visão. E, representando tudo aquilo que abarcamos com o olhar, não é termo seletivo ou restritivo. Não encerra tampouco, nenhum julgamento de valor.

"Paisagem, ao englobar todo o ambiente visual a partir de um ponto de observação qualquer, não pode ser identificado com o conjunto de acidentes geográficos dessa porção de terra. Mais complexo que isso, envolve, além da base física, constituída pela porção correspondente da litosfera, e dos recursos hídricos locais, todo o conjunto dos seres vivos que aí habitam, inclusive o homem.

"Paisagem não é estática, pois todos os seres elementos constituintes são passíveis de transformações próprias, como também se alteram mutuamente.

"Um território é formado de um número infinito de paisagens parcialmente superpostas. Destacar desse conjunto certas áreas, certas paisagens, às quais conferimos determinado significado estético, cultural, científico ou social, e tratar essas áreas como unidades autônomas poderá constituir uma medida funcional correta com vistas a determinadas finalidades. A paisagem, entretanto, permanecerá sempre indivisa, contínua, onde os limites teóricos perdem sua validade."

\footnotetext{
${ }^{88}$ MARX. Citado por MACHADO. O estudo da paisagem - uma abordagem perceptiva. Revista Geografia e Ensino, n.8, 1988, p. 39.
} 
Embora já tenham sido percorridos aí mais de 20 anos, as definições de Burle Marx encontram-se ainda bastante atuais e demonstram uma característica de integração dos elementos que é essencial em Geografia.

Mas Tricart, citado por Machado ${ }^{89}$,

“lembra que na França o termo 'paysage' deriva do termo 'pays', que tem uma forte conotação territorial, o mesmo acontecendo com o do alemão 'landschaft' e 'land' , que designa os estados cuja associação forma a República Federal. Não deixa de chamar a atenção para Paul Vidal de La Blache, que fundou a Geografia Regional sobre o estudo dos 'pays' tradicionais da França. Mas destaca que em inglês a palavra 'landscape' não tem significado científico particular. Analisa as colocações de Deffontaines e de Cholley, para os quais a paisagem é um indício, um 'suporte' (support), devendo ser tomada em consideração globalmente, e não segundo os diversos pontos de vista setoriais, pois que ela, em essência, possui qualquer coisa de concreto: uma porção do espaço perceptivel a um observador onde se inscreve uma combinação de fatos visíveis e de ações das quais, num dado momento, só percebemos o resultado global. A estas colocações Tricart acrescenta: uma paisagem começa mais ou menos nitidamente em um lugar e termina num outro; sua extensão pode ser cartografada; uma unidade territorial; sob certo ponto de vista, é também uma paisagem.

A questão é que, em se tratando de paisagem, nem mesmo as definições, por mais claras que sejam, conseguem precisar o objeto em questão. Uma importante contribuição é dada por Ab'Saber $^{90}$, ao colocar que

"a paisagem é sempre herança, em todo o sentido da palavra: herança de processos fisiográficos e biológicos e patrimônio ${ }^{91}$ coletivo dos povos que historicamente as herdam como território de atuação de suas comunidades. Mais do que simples espaços territoriais, os povos herdam paisagens $e$ ecologias, pelas quais certamente são responsáveis, mas todos têm uma parcela de responsabilidade permanente de uma herança única que é a paisagem terrestre.

\footnotetext{
${ }^{89}$ MACHADO. O Estudo da Paisagem - uma abordagem perceptiva. Revista Geografia e Ensino, n.8, 1988 , p. 39.

${ }^{90}$ AB'SABER. Potencialidades paisagísticas brasileiras, Geomorfologia, n.55, 1977, p.37.

${ }^{91}$ Grifo nosso.
} 
Esta definição afigura-se como sendo de grande importância para os estudos geográficos, e sobretudo para a análise que se busca neste trabalho. Ora, sendo a paisagem o resultado de um processo, ligado a fatores históricos e culturais, ela é o resultado de toda ação humana no meio que o cerca. Dessa forma, pode-se avaliar a importância da paisagem, visto que, além de ser sujeito, é também objeto. De qualquer forma, sob qualquer ponto de vista que se trabalhe, trata-se de um elemento complexo, e a Geografia sendo uma ciência que busca analisar todos os aspectos de uma realidade, tem na paisagem o seu mais perfeito objeto de análise. A complexidade desse objeto é tamanha que, segundo Wieber, citado por Machado ${ }^{92}$, “chama a atenção para a indeterminação da noção de paisagem, cujo termo está longe de ser claramente definido". Diante da dificuldade de se ter uma clara noção do termo, Wieber classifica a paisagem em três níveis: no primeiro, ela é o produto de um sistema de forças em funcionamento, estudada por observações e medidas indiretas; no segundo, ela é o produto da percepção, ou seja, a análise deve ser feita a partir da maneira pela qual a paisagem é percebida; e no terceiro, o nível a paisagem pode ser encarada como um objeto em si, como paisagem visível e funciona associando os objetos para criar as imagens. Para o autor, esta é uma abordagem sistêmica, onde os três níveis estão ligados entre si e se relacionam. De qualquer forma, a paisagem apresenta-se como um elemento extremamente complexo, que envolve uma série de relações em si mesma, e que pode ser modificada ao longo do tempo.

Particularmente, concorda-se com Burle Marx ao colocar a importância da escala quando se quer trabalhar com paisagens e, dentro de uma delas, pode-se identificar uma grande variedade de quadros cênicos, cuja escala de trabalho - caso haja interesse na particularização - não será a mesma que aquela utilizada para a totalidade do conjunto. No trabalho desenvolvido por esta equipe em Goiás, começou-se trabalhando com uma área cuja análise se fazia em escala regional: a área que seria ocupada pela represa de Serra da Mesa equivale a $1.780 \mathrm{Km}^{2}$. Para um primeiro exame da proposta de trabalho ela era viável, mas para o desenvolvimento da pesquisa propriamente dita fazia-se necessário trabalhar com regiões menores, e esse foi o primeiro passo que a equipe tomou. Em seguida, definidas áreas menores de trabalho, a procura dos sítios arqueológicos, sob a forma de prospecção, começou a ser realizada, e a partir daí verificou-se a necessidade de buscar conjuntos paisagísticos,

\footnotetext{
${ }^{92}$ MACHADO.O estudo da paisagem - uma abordagem perceptiva, Revista Geografia e Ensino, n.8, 1988, p.40.
} 
onde, em determinados casos, estes conjuntos eram indícios da ocorrência de certos tipos de sítios - fato que às vezes confirmava-se, outras não.

Estes sítios arqueológicos, dentro de determinados contextos paisagísticos, remonta a idéia de patrimônio cultural. O que de fato ocorria é que expressões importantes, mas absolutamente desconhecidas do nosso Patrimônio Cultural estavam correndo o risco de se perderem, bem como o próprio contexto paisagístico onde elas estavam inseridas. A questão é saber até que ponto justifica-se o trabalho de salvamento dessas ocorrências, na medida em que o contexto deixaria de existir. O trabalho em Serra da Mesa procurou registrar, com abundância, o entorno e a paisagem dos sítios encontrados, para que, dentro do possível essas informações não se perdessem completamente. Nesta análise, torna-se de suma importância a conceitualização de Ab'Saber em que a paisagem é também encarada como uma herança. Para os pesquisadores de Serra da Mesa, a herança paisagística era fundamental para definição das áreas de pesquisa. Essa herança paisagística começava a se constituir, para a equipe, em herança cultural.

\section{Geografia e Cultura}

A ciência geográfica apresenta-se como sendo integradora de diversas correntes de pesquisadores, e como já foi dito, definir o seu objeto não é tarefa fácil. De acordo com a abordagem escolhida, pode-se analisar um mesmo território sob diversos aspectos. No entanto, não é possível, ou pelo menos não é aconselhável, trabalhar-se sem analisar os aspectos da interferência humana no espaço. O espaço geográfico só tem sentido quando observado sob o ponto de vista das relações humanas nele estabelecidas. A forma de apropriação do espaço e os interesses envolvidos nesse processo é que dão conformidade e importância a um determinado território. 
No Brasil, a ocupação territorial durante o período colonial esteve vinculada, essencialmente à necessidade de expropriação de riquezas e expansão do domínio territorial.

"Se é certo que, da enorme porção do mundo que 'as armas e os barões assinalados' conquistaram, dilatando 'a fé e o império', tudo perderam mais tarde, não lhes restando no Oriente mais que alguns palmos de terra onde chantar o glorioso estandarte das Quinas, - o Brasil, não obstante os erros graves da política de sua metrópole, há de servir, pelos séculos em fora, para atestar a energia prístina dos lusos, sobrepujada logo pela dos seus descendentes, filhos destas ridentíssimas plagas do Novo Mundo, que devassaram o coração e os confins do colosso sul-americano, e o ergueram, depois, à face do orbe, como o florão mais belo e imperecível da audácia antiga dos maiores pioneiros da sede imensa, e por tanto tempo desconhecida, do planeta humano." 93

A forma de ocupação do território e a vivência dele pelos três grupos raciais que formaram a sociedade brasileira dão-lhe as características culturais que lhe são próprias. Obviamente que as expressões culturais são muitíssimo variadas, influenciadas tanto pela extensão espacial do país quanto pela heterogeneidade dos seus elementos formadores. Devido a estas reflexões, pode-se dizer que a Geografia não pode analisar, de forma estanque, o elemento espaço, sem considerar as relações humanas aí estabelecidas. Conseqüentemente, Geografia e cultura são dois objetos de análise que não devem ser dissociados.

Culturalmente, a sociedade brasileira é extremamente rica, e essa riqueza cultural expressa-se nos componentes espaciais do seu território. Tal fato justifica amplamente a análise deste trabalho em que, através de uma pesquisa de salvamento arqueológico, busca-se estudar a forma de ocupação e apropriação de parte do território brasileiro, mais especificamente do território goiano. As expressões culturais percebidas no espaço apresentam-nos formas diferentes de ocupação e de apropriação desse mesmo espaço, bem como expressões materiais, que nada mais são do que formas de manifestações culturais, associadas a uma determinada sociedade - no caso uma sociedade basicamente rural, com grande inserção também na exploração mineral.

\footnotetext{
${ }^{93}$ MAGALHÃES. Expansão geográfica do Brasil colonial,1978,. P.13.
} 
Dessa forma, procura-se expressar que os elementos geográficos são extremamente importantes para a análise da cultura, uma vez que as manifestações humanas sobre o território se dão de maneiras diferentes, visto que os elementos que irão interferir nesse processo são amplos e complexos. Para o Brasil, e sobretudo para a área de estudo em questão, estes elementos estão ligados, por exemplo, aos fatores naturais, à forma de ocupação e exploração do território no período colonial, (quando o Brasil era tido como fonte de riquezas e expressão de poder para a coroa portuguesa), ao segmento da sociedade que se estabeleceu na região a partir de então (uma sociedade rural, escravista e mineradora).

Para um país de dimensões continentais como o Brasil, os aspectos culturais distintos conferem a cada região uma unidade cultural, bem como uma identidade, embora dentro desta unidade possam existir variados elementos de origem distintas e até mesmo divergentes. Machado, citando Guattari, afirma que

"identidade é aquilo que faz passar a singularidade de distintas maneiras de existir por um só e mesmo quadro de referenciais identificável. (...) A identidade tem como suporte fundamental a memória, mecanismo de retenção de informação, conhecimento, experiência, em nivel individual e social, sendo eixo de atribuições, que articula e categoriza os aspectos multiformes de realidade, dando-lhes lógica $e$ inteligibilidade". 94

Ora, para se proceder com eficiência uma análise onde se busca identificar e relacionar cultura e Geografia, faz-se necessário permear-se pela memória cultural do segmento com que se está trabalhando. E a memória está expressa em tudo aquilo que se considera relevante, dentro de uma expressão cultural, sejam objetos, sejam conhecimentos, ou arte, desde que passíveis de registro e perpetuação.

Um trabalho de salvamento arqueológico como o empreendido em Serra da Mesa visa a resgatar elementos materiais que expressem a Cultura local, mesmo que já não sejam mais considerados como relevantes para a sociedade atual. Em verdade, a grande maioria dos objetos resgatados na região de Serra da Mesa já não tinham importância dentro do contexto atual. A maioria das pessoas da comunidade local nem sequer compreendiam o interesse

\footnotetext{
${ }^{94}$ MACHADO \& ATAÍDES. Identidade cultural e memória - objetos de construção do patrimônio histórico, Revista de Divulgação Científica, v.2, 1998, p.42.
} 
daquele grupo de pesquisadores em procurar objetos antigos e abandonados, coisas "sem valor ou importância". Comumente, essas pessoas nem sequer acreditavam no verdadeiro propósito da pesquisa, muitas vezes duvidando que tantas pessoas, portando diversos equipamentos e mapas pudessem estar interessadas em objetos sem valor, preferindo acreditar que o que se buscava eram minas de ouro, para evitar que estas pudessem ser inundadas pela represa da UHE de Serra da Mesa. Assim, nem sempre foi possível contar com a colaboração da comunidade local para a localização de sítios ou vestígios arqueológicos, visto que as pessoas se sentiam inseguras e com receio de serem lesadas no aspecto econômico. Tal fato se deu sobretudo por se tratar de uma população simples, em sua maioria composta por pessoas que viveram toda a sua vida no meio rural, e que não tinham muita convicção das mudanças que estavam ocorrendo naquele momento de suas vidas. Alie-se a isto o fato de se tratar de uma área de mineração, onde naturalmente (ou melhor, culturalmente) as pessoas são desconfiadas por princípio. Em área de mineração, as informações mais simples podem ser fundamentais para um garimpeiro, e a quantidade de pessoas envolvidas nessa atividade é muito grande; o dinamismo dessa população é igualmente difícil de ser mensurado. Pessoas envolvidas no processo mineratório não são pessoas cujos vínculos com a terra sejam fortes; normalmente apresentam-se como itinerantes, não têm desenvolvida a consciência ambiental - depredar os recursos naturais são meios plausíveis, que justificam os fins, e geralmente está ligada à questão da técnica. . Dessa forma, uma das técnicas mais comuns encontradas na região, é a da garimpagem por processo de desmonte, onde os indivíduos, envolvidos no processo, vão "desmontando" os barrancos dos rios e lavando o minério daí retirado, em busca do metal precioso. Comumente encontram-se vestígios desse tipo de mineração pela área pesquisada, sendo que alguns são muito antigos, outros são recentes, e muitos são atuais. O cascalho lavado é abandonado nas proximidades, formando, em alguns lugares, verdadeiros monturos, que se estendem por várias centenas de metros. Assim, as áreas de mineração são características da paisagem local, e, como coloca Milton Santos, citando André Fel,

"toda paisagem habitada pelos homens traz a marca de suas técnicas. (...) A paisagem não é senão um ponto de partida. Se os objetos técnicos ocupam a superfície da Terra, é para atender às necessidades materiais fundamentais dos homens: alimentar-se, alojar-se, deslocar-se, cercar-se de objetos úteis. 
A análise geográfica ocupa um lugar em qualquer investigação sobre as civilizações. "95

Uma importante observação sobre a área em estudo é exatamente sobre a questão da construção da paisagem ao longo do tempo e com relação à aplicação técnica nesse modelar do espaço. Se, no início da ocupação da região, as atividades giravam em torno da mineração como atividade nuclear, com a decadência da mineração a atividade rural foi ganhando expressão, e apresenta-se como uma forma de ocupação do espaço completamente diferente (com impactos ambientais bem menos expressivos), embora em toda a história regional a mineração não tenha nunca sido completamente abandonada.

De qualquer forma, pela extensão da área ocupada pela represa da UHE de Serra da Mesa - cerca de $1780 \mathrm{Km}^{2}$ - há que se considerar que a análise também deve ser abrangente, além é claro de o ser no tempo, já que estão sendo considerados fatores históricos. Do ponto de vista geográfico, deve-se observar que os elementos que modelaram a paisagem - sendo elementos culturais, expressos por técnicas diferentes - são também diferentes no tempo e no espaço; muito embora tenha-se percebido que, em muitos casos, a repetição de um certo fator ou técnica pode ser fundamental para caracterizar uma determinada paisagem. Assim, pode-se, por exemplo, verificar que, embora a técnica do "desmanche" tenha sido importante elemento construtor de paisagens de mineração, as técnicas empregadas ao longo do tempo foram diferentes, sendo que atualmente os garimpeiros utilizam-se até de tratores para retirar o sedimento que será lavado durante o processo de busca do ouro.

Dessa forma, verifica-se que o resultado expresso na paisagem pode até ser o mesmo, ou muito próximos um do outro (guardadas as devidas proporções quanto ao grau de depredação). No entanto, o resultado final é produto de técnicas diferentes, que só fazem sentido se contextualizadas e analisadas em conjunto com outros elementos culturais. Ainda de acordo com Milton Santos, "sem dúvida, a técnica é um elemento importante de explicação da sociedade e dos lugares, mas, sozinha, a técnica não explica nada". 96

\footnotetext{
${ }^{95}$ SANTOS. A natureza do espaço: técnica e tempo; razão e emoção, 1999, p.30.

${ }^{96}$ SANTOS. A natureza do espaço: técnica e tempo; razão e emoção, 1999, p.38.
} 
No entanto, a observação da variação tecnológica ao longo do tempo pode indicar as diferentes formas de apropriação do espaço. Através da pesquisa arqueológica, verificam-se técnicas e tecnologias em desuso pela sociedade atual, e também as diferenças na maneira que uma mesma sociedade se apropria do seu espaço ao longo do tempo. Há aí uma análise que permeia pela cultura, ou seja, o saber fazer, o como fazer que se modifica, ao longo do tempo, e indica mudanças no processo cultural de uma determinada sociedade. E a análise dos objetos abandonados pode ser também uma forma de se analisar esse processo cultural através de objetos ou técnicas, como, por exemplo, técnicas construtivas; identificar as técnicas das construções antigas leva os pesquisadores a inferir sobre o uso que lhes é atribuído, e a importância que elas adquiriram dentro da comunidade em questão.

De certa forma, a pesquisa arqueológica é, portanto, indissociável da Geografia. Não é possível buscar descobrir como funcionou uma sociedade no passado, sem se analisar a paisagem e o sítio onde essa mesma comunidade esteve inserida. Tal análise é eminentemente geográfica.

Nem sempre é possível contar com registros históricos para uma análise desse tipo. Quando tal fato é passível de ser feito, nem sempre os registros podem ser completamente confiáveis. Além do mais, existe um hiato entre o que está registrado e o que foi vivido. Somente a associação de ambos, através de uma análise criteriosa dos vestígios materiais encontrados, pode levar a uma visão mais próxima da realidade. O importante é considerar sempre que cultura é um elemento dinâmico, envolve uma série de parâmetros que nem sempre se está apto a perceber. O geógrafo é um importante pesquisador nesta análise, visto que à sua formação, dentro das ciências humanas, soma-se a sua percepção espacial, elemento fundamental numa análise desse tipo.

De qualquer forma, o dinamismo da cultura requer sempre um cuidado maior quando se trata do assunto. De acordo com Gabriel Cohn,

"cumpre no entanto reconhecer que a cultura é uma ordem de fenômenos que não facilita seu equacionamento em categorias unívocas, sejam ou não propícias as condições políticas e sociais para fazê-lo. Na realidade, se alguma vez. 
existiu uma entidade fugidia e refratária à fixação em fórmulas rígidas, essa é o complexo simbólico denominado cultura - um dos mais desconcertantes conceitos do pensamento moderno. (...) sendo da ordem do simbólico, a cultura é sempre uma coisa: é detectável nos traços que deixa, mas não é identificável como coisa fixa e bem delimitada (...) é rebelde à rigidez conceitual; demanda flexibilidade no pensamento e na ação. Por isso mesmo, toda fala sobre cultura, que é inevitável se aceitarmos que ela constitui dimensão decisiva da vida social, pressupõe a fixação quando nada, para fins de entendimento, de dimensões específicas de um processo multifacético, e implica assumir uma posição perante esse processo". 97

Se na análise apresentada considerar-se que a região em estudo é o resultado de um conjunto de elementos culturais, associados às especificidades geográficas regionais, pode-se inferir que o resultante desse somatório é uma memória específica, ligada aos fatores determinantes acima mencionados. De acordo com Gonçalves, citado por Machado "8 , "a idéia de um passado ou de uma memória como um dado relevante na construção de identidades pessoais e coletivas pode ser pensada como uma invenção que data de fins do século XVIII. A segunda metade do século e as primeiras décadas do século XIX foram pródigas naquilo que Eric Hobsbawn chamou de tradições inventadas: monumentos, relíquias, festas, mitologias nacionais, folclore, mártires nacionais; são um vasto conjunto de tradições inventadas com o objetivo de criar e comunicar identidades nacionais."

Na região em estudo, o que se observa é que os aspectos culturais são obviamente bastante específicos de uma sociedade interiorana, com uma forte concentração fundiária e cujos aspectos econômicos são muito pouco dinâmicos. Assim sendo, consegue-se justificar a manutenção da tradição mineradora local, mesmo no período atual, quando as jazidas auríferas estão claramente esgotadas ou muito próximas disso. No entanto, a "cultura do ouro" é um elemento difícil de ser rompido, visto que as pessoas preferem acreditar na possibilidade de mudar de vida a partir de um golpe de sorte do que acreditar na dura realidade econômica local, com poucas opções de trabalho e quase nenhuma de ascensão social. Um importante fator para a economia regional foi a construção da hidrelétrica de Serra da Mesa, que se

\footnotetext{
${ }^{97}$ COHN. Concepção oficial de cultura e processo cultural. Revista do Patrimônio Histórico e Artístico Nacional..n.22, 1987, p.09-10.

${ }^{98}$ MACHADO \& ATAÍDES. Identidade cultural e memória - objetos de construção do patrimônio histórico, Revista de Divulgação Científica,v.2. 1998, p.60.
} 
firmou culturalmente como o novo eldorado, capaz de restabelecer as bases econômicas da região; num primeiro momento com a oferta de um grande número de empregos, e num segundo momento como elemento de forte atração turística, criando grandes expectativas de dinamização da economia no futuro.

Cabe aí novamente uma análise geográfica mais detalhada: haverá fundamento para tanta expectativa quanto à dinamização da economia local? Será a represa elemento paisagístico suficiente para se tornar fator atrativo, num nível mais amplo que o local a ponto de atrair turistas de outras regiões e municípios?

Certamente que as respostas a estas questões só serão conhecidas com o decorrer do tempo, mesmo porque a questão da dinamização da economia local não pode ser restringida a fatores locais, mas depende de uma série de elementos interligados entre si, como por exemplo o próprio comportamento da economia em escala nacional e até internacional. A busca por viagens turísticas dentro do território brasileiro está muito vinculada a fatores internacionais como por exemplo a cotação do dólar, o interesse e a capacidade monetária do turista brasileiro, a relação entre o custo de se fazer viagens ao exterior e viagens pelo próprio país. Tudo isso são elementos a ponderar, além, é claro, do próprio investimento que será feito no futuro nas cidades que margeiam o lago, investimentos estatais em infra estrutura, como a melhoria dos serviços de saneamento básico, o incremento e melhoria da rede viária, a adequação do único aeroporto da região, situado em Niquelândia, etc. Além disso, há os investimentos que deverão ser feitos pela própria iniciativa privada, como a melhoria do setor hoteleiro da região, que é extremamente modesto, os investimentos no setor de telefonia, tanto fixa quanto móvel, o setor de bares e restaurantes, também muito simples, carecendo de novos investimentos e de modernização, entre outros.

Outra preocupação é quanto ao aspecto cultural propriamente dito. Trata-se de uma região de baixa densidade populacional, e grande parte da população atual é oriunda de outras áreas, sobretudo Minas Gerais e região Nordeste do Brasil. Pode-se dizer que se trata de pessoas cujo vínculo com o lugar está estabelecido há pouco tempo, geralmente há uma geração anterior. Dessa forma, já se é um conjunto heterogêneo do ponto de vista cultural. Se a questão do turismo realmente vier a se estabelecer e se firmar como atividade econômica importante, ter-se-á aí um processo de numerosos contatos diretos com outras realidades 
culturais que são estranhas ao lugar, podendo levar a um processo de propagação e absorção muito rápida de manifestações culturais diferentes daquelas estabelecidas até então.

Isso é necessariamente bom ou ruim? Nenhum dos dois, ou talvez ambos. O fato é que mudanças ocorrerão com certeza, e como em todas as áreas cuja economia se baseia no turismo, corre-se o risco de que as mazelas decorrentes desse processo também se instalem, tal como aumento do número de pessoas desocupadas e pedintes, aumento da prostituição, aumento do número de pessoas envolvidas na economia informal, etc.

O fato é que, dentro desta análise, busca-se compreender que, se a cultura não é um elemento estanque e fechado em si mesmo, as mudanças que venham a ocorrer não têm que ser consideradas apenas como positivas ou negativas, mas componentes de um processo, e como tal requerem uma compreensão mais global do processo.

Essa área de estudo caracteriza-se por um conjunto multifacetado de elementos culturais desde os primórdios de sua ocupação, quando se deu a expansão colonial em direção ao interior do Brasil, impulsionados por interesses econômicos e de dominação. De lá para cá, o processo de ocupação passou por várias etapas, mas, como se trata de uma área mais distante dos principais centros econômicos dinâmicos do país, a apropriação da terra sempre foi um processo de exploração, sem maiores preocupações com a natureza ou o meio ambiente. Haja vista que a vegetação típica da região - o cerrado - é justamente o segundo bioma brasileiro em extensão e o mais amplamente degradado. $\mathrm{Na}$ área de estudo, este fato não é exceção. A degradação ambiental ocorre em vários níveis: desmatamentos, queimadas, mineração com máquinas como dragas e tratores; uso indiscriminado de mercúrio, poluindo os manancias, etc. Esta falta de consciência ambiental também se afigura como uma questão cultural.

Não se deve restringir a cultura às suas expressões artísticas; se ela pode ser definida como o saber fazer, o como fazer é a sua forma de expressão. Talvez a própria exuberância da natureza e o contato mais direto com ela possa ter criado, na comunidade local, um sentimento de pouca preocupação com ela, uma diminuição da percepção dos efeitos adversos, causados pelas relações predatórias aí estabelecidas e a sensação errônea de que a natureza é infinita e que os elementos naturais têm uma 
capacidade irrestrita de se recuperarem dos danos causados pelo homem, sobretudo nesse processo (geralmente conflitante) de modernização de uma sociedade.

"Ser moderno é encontrar-se em um ambiente que
promete aventura, poder, alegria, crescimento,
autotransformação e transformação das coisas ao redor-mas
ao mesmo tempo ameaça destruir tudo o que temos, tudo o que
sabemos, tudo o que somos. A experiência ambiental da
modernidade anula todas as fronteiras geográficas e raciais, de
classe e nacionalidade, de religião e ideologia, nesse sentido,
pode-se dizer que a modernidade une a espécie humana. Porém,
é uma unidade paradoxal, uma unidade de desunidade: ela nos
despeja a todos num turbilhão de permanente desintegração e
mudança de luta e contradição, de ambigüidade e angústia. Ser
moderno é fazer parte de um universo no qual, como disse
Marx, tudo o que é sólido se desmancha no ar..."

Sobre a questão do desenvolvimento econômico, modernidade e progresso, Lutzemberger ${ }^{100}$ coloca que:

"A quase totalidade do que convencionamos chamar de 'progresso' não é outra coisa que um incremento na rapina dos recursos naturais (...). Enquanto o progresso da vida, através das intermináveis eras da evolução, significava aumemto constante do capital ecosférico, com aprimoramento progressivo da homeóstase, o 'progresso' do homem moderno não é senão uma orgia de consumo acelerado de capital, com aumento paralelo na vulnerabilidade do sistema."

Esta é mais uma questão a se ponderar, caso venha a ocorrer a tão esperada dinamização da economia, através do turismo. Duas perspectivas abrem-se a partir desse ponto: ou poderá ocorrer um processo de degradação ambiental em larga escala ou poderá ser feito, em benefício da atividade turística, um trabalho de conscientização populacional, buscando resgatar a preocupação com a preservação ambiental, e, a partir daí, criar-se um vínculo de compromisso entre a população e o meio ambiente, visando à manutenção da fonte de recursos, através da conservação do patrimônio natural. Talvez até pela amplidão da área em questão, possam prevalecer ao mesmo tempo ambas as premissas, embora sejam

\footnotetext{
${ }^{99}$ BERMAN, citado por VESENTINI. Geografia, natureza e sociedade, 1997, p. 23.

${ }^{100}$ LUTZEMBERGER, citado por DIEGUES.O mito da natureza intocada, 1996, p.127.
} 
aparentemente antagônicas. No entanto, como não existe política educacional eficaz para atingir $100 \%$ de uma coletividade, tal fato não é impossível.

De fato, as relações que se estabelecerão, indicam uma outra análise: a de que a nova paisagem, criada a partir da construção da UHE de Serra da Mesa levará a uma re-valorização do lugar, ou dos elementos paisagísticos reelaborados. O que cria novos vínculos entre a comunidade e o espaço vivido, oferecendo novas expectativas de vida e de mudanças estruturais, no seu dia a dia. Novas relações culturais passam, então, a ser estabelecidas, tendo como elemento dinamizador as relações espaciais.

No entanto, lugares e paisagens não são necessariamente sinônimos, visto que a abrangência espacial do primeiro é menor, mas, ou por isso mesmo, a vivência e o conhecimento deste pela comunidade é bem maior do que a daquela. De acordo com A. Carlos, citado por D. Rockenbach,

"o lugar é o produto das relações humanas, entre homem e natureza, tecido por relações sociais que se realizam no plano do vivido, o que garante a construção de uma rede de significados e sentidos que são tecidos pela história e cultura civilizadora produzindo a identidade, posto que é aí que o homem se reconhece porque é o lugar da vida."

Tanto em uma análise local como em uma análise global, pode-se considerar que as relações entre o homem e a natureza estão permeadas de aspectos culturais, e, portanto, são mutantes e dinâmicas. Não é possível conceber uma sociedade humana sem dinamismo cultural, e a Geografia torna-se importante mecanismo para a compreensão destas relações, uma vez que o Homem constrói suas relações culturais no espaço, e é aí que elas se manifestam.

"A história das chamadas relações entre sociedade e natureza é, em todos os lugares habitados, a da substituição de um meio natural, dado a uma determinada sociedade, por um meio cada vez mais artificializado, isto é, sucessivamente instrumentalizado por essa mesma sociedade. Em cada fração da superfície da terra, o caminho que vai de uma situação a outra se dá de maneira particular; e a parte do 'natural' e do

\footnotetext{
${ }^{101}$ CARLOS, citado por ROCKENBACH. Resgate da identidade - registrando um projeto e investigando a relação identidade-espaço, 1999, p.25.
} 
'artificial' também varia, assim como mudam as modalidades do seu arranjo". 102

\section{Geografia e Paisagem}

A paisagem, passível de inúmeras definições, como já foi visto, é constituída de elementos vivos e elementos não vivos. Os primeiros constituem-se pelas diferentes formações vegetais e animais, que interferem e conformam o objeto paisagístico. Certamente que as interferências humanas, também outro elemento vivo dentro da paisagem, reconfiguram os seus aspectos, desde os mais visíveis até aqueles menos perceptíveis ao olhar (a contaminação do solo e da água, por exemplo, por agentes químicos, etc.).

Geralmente as formações vegetais apresentam características que comumente conferem a um lugar uma determinada especificidade dentro do conjunto da paisagem. Mesmo este elemento pode configurar características diferentes ao olhar do observador se forem levados em consideração outros fatores, agora considerados não-vivos, mas igualmente dinâmicos, como o clima, por exemplo. Uma mesma vegetação vai-se apresentar de forma diferente conforme a estação climática em que é observada. Assim é que uma paisagem, composta predominantemente por elementos naturais, como a da região de Serra da Mesa, vai apresentar características visuais completamente diferentes, se observadas nos meses de junho e julho, que é um período seco; e nos meses de novembro e dezembro, em pleno período chuvoso, quando a vegetação apresenta-se em toda a sua exuberância e os cursos d'água estão com sua capacidade de vazão ampliada.

Não é aconselhável analisar os elementos paisagísticos de forma individual ou estanque; por isso mesmo, consideradas as devidas observações, deve-se sempre procurar estabelecer critérios que identifiquem a paisagem como um todo, indissociável, ainda que composto por partes distintas.

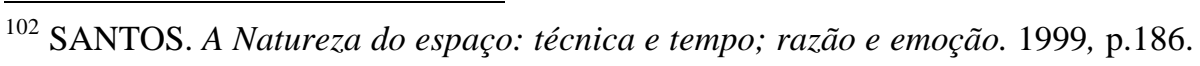


Essa dificuldade de se lidar com conceitos e com definições remete a uma questão de ordem prática, uma vez que nos trabalhos de pesquisa faz-se necessário delimitar e definir com clareza o objeto estudado. Com relação à paisagem, ela pode ser trabalhada também como Patrimônio Natural. Este é outro conceito difícil de ser analisado, embora exista uma série de definições para a expressão. O grande problema é que países de dimensões continentais como o Brasil, com uma política ambiental e patrimonial ainda jovem e pouco estruturada, em que os mecanismos de preservação e de controle são relativamente precários, as dificuldades somam-se diante dos pesquisadores.

É importante lembrar que a questão da preservação, tanto de um patrimônio cultural quanto de um patrimônio natural só se dá porque estes passam pela ameaça de serem destruídos. Este é um grande dilema da civilização moderna: conciliar desenvolvimento tecnológico e científico com crescimento econômico, sem destruir o patrimônio legado - seja pela natureza, seja pelas gerações passadas. José Lutzemberger coloca que:

"eu diria que a simples exigência do estabelecimento de uma área de preservação já é uma confissão de que a nossa atual civilização, a nossa atual forma de cultura, o que nós chamamos a sociedade industrial moderna, é um esquema suicida. Porque uma cultura que precisa preservar a natureza de si mesma não pode estar certa."

De fato, tanto o meio ambiente quanto o patrimônio cultural correm riscos de serem destruídos, em maior ou menor escala, de acordo com as necessidades de crescimento e desenvolvimento da nossa sociedade, e porque não, de acordo com o grau de irresponsabilidade e de imaturidade dessa mesma sociedade, que imprime pouca importância a estes aspectos. De acordo com o geógrafo Nivaldo Chiossi, citado por Horieste Gomes,

"mais forte do que os efeitos de vulcões e terremotos, que felizmente não temos, a irresponsabilidade administrativa dos governos anteriores permitiu que a degradação ambiental explodisse de forma assustadora por todo o país",. ${ }^{104}$

${ }^{103}$ LUTZEMBERGER. Patrimônio natural, Revista do Patrimônio Histórico e Artístico Nacional, n. 22, 1987, p.218.

${ }^{104}$ CHIOSSI, citado por GOMES. A questão ambiental: idealismo e realismo ecológico, Terra Livre, n. 3, 1988, p.37. 
Passados mais de dez anos desta declaração, pode-se constatar que muito pouca coisa mudou, e que os governos que se sucederam não adotaram uma política de fato engajada com a preservação do nosso Patrimônio.

Já em 1962, a UNESCO preocupava-se com o patrimônio natural a nível global, e através da sua $12^{\mathrm{a}}$ Sessão, realizada em Paris, elaborou a Recomendação Relativa à Salvaguarda da Beleza e do Caráter das Paisagens e Sítios, onde, dentre outras coisas considera que:

"em todas as épocas o homem algumas vezes submeteu a beleza e o caráter das paisagens e dos sítios que fazem parte do quadro natural de sua vida a atentados que empobreceram o patrimônio cultural ${ }^{\mathbf{1 0 5}}$, estético e até mesmo vital de regiões inteiras, em todas as partes do mundo. Ao cultivar novas terras, desenvolver por vezes desordenadamente os centros urbanos, executar grandes obras e realizar vastos planejamentos físicoterritoriais e instalações de equipamento industrial e comercial, as civilizações modernas aceleram esse fenômeno que, até o século passado, havia sido relativamente lento. (...) Por sua beleza e caráter, a salvaguarda das paisagens e dos sítios definidos pela presente recomendação é necessária à vida do homem, para quem são um poderoso regenerador físico, moral e espiritual e por contribuírem amplamente para a vida artística e cultural dos povos, como o demonstram inúmeros exemplos universalmente conhecidos. ${ }^{\prime 106}$

Embora muito pertinente a preocupação da UNESCO, carece, no entanto, de efetiva implementação. A sociedade brasileira é composta em sua maioria por uma população carente dos recursos básicos mínimos necessários a uma vida digna, dentre eles, educação. O trabalho que deve ser desenvolvido junto a essa população é basicamente educacional, norteando-se pela educação ambiental. Mas tal fato só terá sentido se paralelamente forem desenvolvidas condições dignas de vida e trabalho, caso contrário, a questão ambiental soa como um discurso vazio.

Historicamente nunca se prima pela preocupação com a degradação do meio ambiente. Tal fato pode ter várias justificativas, mas as que mais chamam a atenção estão ligadas à formação cultural e à ocupação territorial.brasileiras Um país que nasceu como colônia de

\footnotetext{
${ }^{105}$ Grifo nosso.

${ }^{106}$ INSTITUTO DO PATRIMÔNIO HISTÓRICO E ARTÍSTICO NACIONAL - IPHAN (Brasil). Cartas patrimoniais, 1995, p.97.
} 
exploração não teve, obviamente, em seus primórdios, a preocupação de desenvolver uma consciência ambiental em seus habitantes.

"A destruição da natureza no Brasil, desde o início parece estar ligada ao interesse do colonizador de não se fixar aqui, mas levar tudo para o Reino. (...) Por mais arraigados (os colonizadores) que na terra estejam, e por mais ricos que sejam, tudo pretendem levar para Portugal e isto não têm só os que de lá vieram, mas ainda os que cá nasceram, que uns e outros usam a terra não como senhores, mas como usufrutuários, só para a desfrutarem e a deixarem destruída". ${ }^{107}$

Sobre o tema, Xavier coloca que, desde o início da colonização do Brasil, a exploração predatória tornou-se marcante e foi internalizada pela população local como uma de suas características naturais. De acordo com o referido autor,

"o vocábulo que hoje designa o natural do Brasil, do século XVI ao XVIII, denominava os indivíduos que se dedicavam ao negócio do pau-brasil. Ao invés de se chamarem brasilianos ou brasilienses os habitantes da nova terra, o gentílico porque ficaram sendo designados ... era o mesmo apelativo que se aplicava aos negociantes de pau-brasil, isto é, brasileiros. Não é de se estranhar que um povo com esse gentílico tenha continuado a praticar, mesmo após a Independência, uma ocupação predatória de seu território." "108

Em raros momentos, levantava-se alguma voz proclamando a preservação, sobretudo de nossas matas, que, pela sua grandiosa exuberância, chamavam a atenção até mesmo daqueles que patrocinavam a exploração predatória. Com raras exceções, como é o caso de José Bonifácio, cujo conhecimento ia além da maioria das pessoas, porque se pautava em um conhecimento científico, baseados em estudos realizados na Europa, de maneira geral a preocupação com a preservação estava mais ligada à questão cênica da paisagem .

"As únicas medidas de contenção da devastação florestal vêm de Cartas Régias da Coroa Portuguesa, no séculos XVIII, que estava preocupada com a falta de madeira para a construção naval.

\footnotetext{
${ }^{107}$ DIEGUES.O mito da natureza intocada, 1996, p.112.

${ }^{108}$ XAVIER.A natureza do patrimônio cultural no Brasil. Revista do Patrimônio Histórico e Artístico Nacional, n.22, 1987, p. 233.
} 
“José Bonifácio, no início do século XIX, tinha grande preocupação com a destruição das matas; sua visão da natureza era distinta da dos romancistas: representava um grande livro, cujo segredo e riquezas poderiam ser arrebatados pelo conhecimento científico. Ele combatia o corte das florestas, pois tinha estudado os efeitos do desmatamento sobre a fertilidade dos solos em Portugal.

"Todos os que conhecem por estudo a grande influência dos bosques na economia geral da natureza sabem que os países que perderam suas matas estão quase de todo estéreis e sem gente.(José Bonifácio)." 109

A paisagem constitui-se em um elemento que geralmente desperta interesse pela sua preservação dentro do enfoque romanceado dos ambientalistas de cunho preservacionistas, cuja preocupação maior reside em preservar sem se preocuparem com o engajamento das sociedades que dela usufruem e com ela permutam relações de vida. No Brasil, sobretudo a partir da década de 70, várias manifestações ambientalistas surgiram na esteira do desenvolvimento e divulgação dos movimentos ecológicos em todo o mundo. Talvez o próprio momento político e econômico por que passava o país tenha propiciado a proliferação deste tipo de manifestação, como uma forma de protesto contra o Estado repressor e como uma forma de crítica ao modelo econômico desenvolvimentista instaurado na época. Diversos grupos engajados politicamente com o pensamento da esquerda filiaram-se a movimentos "verdes", num momento em que o processo econômico favorecia a devastação de paisagens inteiras com o avanço da moderna agricultura, expressa nas agroindústrias e na expansão da fronteira agrícola (da qual o Centro-Oeste brasileiro tem sido palco desde então), e com a proliferação do uso indiscriminado de pesticidas, herbicidas e agrotóxicos, que, sob o pretexto de dinamizar a produção agrícola, favoreceram largamente o desenvolvimento da indústria internacional de insumos.

"A modernização que os governos militares empenharam-se em alcançar baseava-se na industrialização através da implantação no país das multinacionais, daí a necessidade de criação de grandes complexos energéticos geradores de energia elétrica. Esta modernização reduzia-se ainda na incitação ou aquisição dos avanços tecnológicos e científicos dos países centrais." 110

\footnotetext{
${ }^{109}$ DIEGUES.O mito da natureza intocada, 1996, p. 112.

${ }^{110}$ BRENNEISEN, citado por SOUZA. A hidrelétrica de Itaipu : uma represa que (des)configura uma região, Ciência Geográfica, v. IV, 1998, p.11.
} 
Na sociedade moderna,

“a mudança de postura quanto à origem e finalidade da natureza, traz consigo uma importante renovação conceitual. A natureza amiga, mantenedora da vida sobre a Terra, passou a ser uma máquina que se opera e se manipula, desde que sejam conhecidas as regras do seu funcionamento."

Mas será que se está manipulando sempre com o conhecimento dessas regras de funcionamento? Ocorrem comumente situações que nem sempre demonstram isso. Na área de pesquisa, como já foi citado, observaram-se processos de degradação ambiental - sobretudo em áreas de mineração que remontam há mais de 200 anos. Dependendo do tipo de interferência realizada no meio ambiente, a paisagem pode sofrer alterações que jamais serão recuperadas. É justamente o caso da construção da represa de Serra da Mesa. A área que será inundada implica a perda irreversível de paisagens inteiras, muitas delas com conotações de grande valor afetivo para a comunidade local. Estas paisagens estão irremediavelmente sendo substituídas por uma nova, que traz consigo a perspectiva de nova forma de vida e inclusive de novas relações dessa comunidade com o meio ambiente.

O mesmo fenômeno já ocorreu em diversas áreas em que situação semelhante se deu, e já foram analisadas sob os mais diversos aspectos. É o caso, por exemplo, de pesquisadores que trabalharam com áreas impactadas por outros empreendimentos hidrelétricos. ${ }^{112}$ Vera Lúcia dos Santos ${ }^{113}$ trabalha inclusive com a noção de topocídio para caracterizar situações semelhantes à de Serra da Mesa. Segundo a autora,

"a maior tristeza que assola as pessoas que perdem sua cidade, seu bairro, sua propriedade rural, enquanto paisagem vivida, é o sentimento de perda, é o topocídio imposto, que está relacionado diretamente com a perda do lugar que as pessoas aprenderam, durante muitos anos, a apreciar ou desgostar de determinados elementos, além de significar a base sólida de sua sobrevivência, uma vez que por mais carente que o lugar seja

\footnotetext{
${ }^{111}$ FIGUEIRÓ. Evolução do conceito de paisagem: uma breve revisão, Geosul, v.13, n.26, 1998, p.45.

${ }^{112}$ Como exemplo podemos citar as pesquisas de Simone A. Villela, "Nova Ponte, MG - uma paisagem a ser vivida", Dissertação de Mestrado, IGC, UFMG, Belo Horizonte, 1992; Aurora M. Castro D. Silva, "Rio Manso: a vivência do impacto de um grande projeto", Dissertação de Mestrado, IGC, UFMG, Belo Horizonte, 1997; Vera Lúcia dos Santos, "Projetos hidrelétricos de grande porte e efeitos sociais: o exemplo do topocídio provocado pela Barragem de Porto Primavera”, Dissertação de Mestrado, IGCE, UNESP, Rio Claro, 1998. ${ }^{113}$ SANTOS. Projetos hidrelétricos de grande porte e efeitos sociais: o exemplo do topocídio provocado pela barragem de Porto Primavera, 1998, p.22.
} 
em termos de recursos, ali as pessoas desenvolvem suas atividades econômicas, tirando delas o seu sustento."

$\mathrm{Na}$ área em estudo, pode-se buscar analisar a questão sob dois aspectos. O primeiro é a alteração da paisagem em um momento histórico passado, quando a própria tecnologia disponível e utilizada nesse processo era menos desenvolvida, e, portanto, menos impactante do que atualmente. Outro aspecto é a questão da destruição ou substituição das paisagens implementadas pelo poder público, em nome do crescimento econômico, como ocorre no presente, havendo aí uma abrangência territorial e ambiental muito maior.

Atualmente,

"desenvolvimento econômico implica na noção de
progresso material. Evidentemente esta noção de
desenvolvimento, contrasta com a de que o desenvolvimento
deveria ser: atingir a plena potencialidade biológica humana
que é a do pensar. (...)

"No atual momento histórico em que a crise ambiental põe em destaque as contradições da produção social do espaço, onde o ideário do desenvolvimento é predominante, o conceito de desenvolvimento sustentável parece jogar uma cortina de fumaça sobre estas contradições. (...)

“(...) Afirmações de que desenvolvimento sustentável é aquele que atende às necessidades do presente sem comprometer a possibilidade de as gerações futuras atenderem suas próprias necessidades ...(CMMAD, 1991), não explicitam como se podem atender às necessidades presentes e futuras no ... mercado. Até o presente momento, o mercado não atendeu às necessidades de massas de famintos empobrecidos no processo de produção, contudo dilapidou o meio ambiente." 114

Torna-se importante ressaltar que as interferências humanas em um ritmo acelerado e/ou contínuo de modificações paisagísticas que acarretem freqüentes e múltiplos impactos ambientais, podem levar a um desequilíbrio da biosfera, desequilíbrio esse muitas vezes fora

\footnotetext{
${ }^{114}$ RODRIGUES. A questão ambiental e a (re)descoberta do espaço: uma nova relação sociedade/natureza? Boletim Paulista de Geografia, n.73, 1994, p.55-56.
} 
do controle, podendo gerar, em alguns casos, danos irreversíveis ao meio ambiente e às relações de vida que aí existiam. Resta avaliar se os resultados buscados são realmente justificáveis pelos danos causados. E mais ainda, a quem interessa verdadeiramente esses resultados, qual a parcela de interesse social estes resultados alcançam. Se forem realmente positivos, ainda assim há que se avaliar os meios utilizados para alcançá-los, porque

"a paisagem planejada advinda com a implantação de grandes empreendimentos, geralmente é sinônimo de progresso e desenvolvimento, vistos principalmente pela ótica da ideologia desenvolvimentista. No entanto, para as pessoas que são atingidas ela representa, na maioria das vezes, o rompimento com seu estilo de vida, resultando em impactos dificeis de serem mensurados dentro de escritórios de planejamento." 115

\section{A Paisagem como elemento cultural: a área de Serra da Mesa e suas características paisagísticas e culturais}

"A Geografia não pode contentar-se em descrever a paisagem concreta; ela procura compreender e reconstituir o mecanismo que conduz à formação da paisagem e provoca a sua evolução. Nem todos os elementos desse mecanismo são visíveis aos nossos olhos, mas se acham à disposição da nossa curiosidade crítica. Já se disse que o geógrafo é um 'olho' e a Geografia uma maneira de ver. Jamais se pretendeu fazer do geógrafo uma Kodak insensível." "116

Os elementos desse mecanismo são cada vez mais complexos, à medida que as sociedades se tornam culturalmente mais complexas e mais interdependentes entre si, fenômeno cada vez mais comum no momento atual, embora o processo em si de modelar a paisagem seja tão

\footnotetext{
${ }^{115}$ SANTOS. Projetos hidrelétricos de grande porte e efeitos sociais: o exemplo do topocídio provocado pela barragem de Porto Primavera, 1998, p.41.

${ }^{116}$ MONBEIG, citado por SALGUEIRO. Pierre Monbeig: a paisagem na óptica geográfica. Paisagem e Arte: a invenção da natureza, a evolução do olhar, 2000, p.163.
} 
antigo quanto a própria humanidade. Sobre o tema Monbeig ${ }^{117}$ coloca também que "o homem manifesta mais nitidamente sua capacidade de agente geográfico, criador de paisagem, (...) capaz de modelar a natureza e crias paisagens de civilizações”. Ora, "paisagens de civilizações" é uma expressão que só faz sentido se se compreende a paisagem enquanto elemento cultural. A característica de bem cultural está relacionada ao fato de que a paisagem é construída, vivenciada, experienciada através dos tempos por uma determinada comunidade. Volta-se aí ao conceito de identidade cultural. Se existe um componente cultural, que implica experiência e vivência, estabelece-se, neste caso, uma relação de identidade entre as pessoas para com o meio vivido. Essas experiências são geradoras de sentimentos - topofílicos ou topofóbicos, segundo definição de Tuan ${ }^{118}$. De qualquer forma, a paisagem, constituída em bem cultural passa a ser protagonista de laços de identidade, e a partir de então, constitui-se em elemento motivador de interesse pela sua preservação, tanto maior quanto mais for desenvolvida a consciência da coletividade em relação à importância dos bens culturais.

"Existem paisagens, lugares, sítios e monumentos cuja conservação não pode levar-se a cabo independentemente de um conteúdo espiritual próprio ou de um contexto imaterial firmemente ligado aos mesmos. Por outras palavras: tal como uma paisagem pode materializar a lembrança de um acontecimento, o bairro antigo de uma cidade, para conservar todo o seu interesse cultural - não pode entender-se desligado de certas características ambientais e vivenciais ${ }^{119}$ que constituem a própria sobrevivência da consciência coletiva das comunidades que o construíram." 120

A experiência constitui-se assim fator de suma importância na construção da identidade.

\footnotetext{
${ }^{117}$ MONBEIG, citado por SALGUEIRO. Pierre Monbeig: a paisagem na óptica geográfica. Paisagem e Arte: a invenção da natureza, a evolução do olhar, 2000, p.167.

118 YI-FU TUAN. Topofilia: um estudo da percepção, atitudes e valores do meio ambiente, 1980. De acordo com o autor Topofilia é um termo que se refere a todos os laços afetivos dos seres humanos com o meio ambiente, podendo diferir quanto ao grau de intensidade, sutileza ou modo de expressão. Já a topofobia refere-se aos sentimentos de cunho negativo que os seres humanos desenvolvem por determinados lugares, estando geralmente vinculados a experiências negativas experienciadas nesses mesmos lugares.

${ }_{119}$ Grifo nosso

${ }^{120}$ TOLEDO. Bem cultural e identidade cultura, Revista do Patrimônio Histórico e Artístico Nacional, n.20, 1984, p.29.
} 
A importância que a paisagem exerce sobre os seres humanos pode ser percebida desde tempos imemoriais. Já em manifestações gráficas pré-históricas, como as pinturas rupestres, por exemplo, pôde-se identificar representações dos sítios e das paisagens habitadas por aquelas comunidades, além do fato de que os próprios assentamentos humanos, na préhistória, estavam diretamente vinculados ao meio ambiente, devido ao fato de que, a dependência das sociedades primitivas com relação à natureza era efetivamente muito grande.

"A questão se inicia pela forma com que a sociedade percebe o seu habitat (cenário natural da existência humana, as condições físicas da região habitada por um grupo de gente, seus recursos naturais, real ou potencialmente à sua disposição, seu clima, altitude e outras condições geográficas às quais se adaptou); como é sua cultura (refere-se àquela parte do ambiente total que compreende os objetos materiais de manufatura humana, as técnicas, as orientações sociais, os pontos de vista e os fins consagrados que constituem os fatores imediatos condicionantes em que se cimenta a conduta humana), e como vive em seu ambiente (o agregado de todas as condições $e$ influências externas que afetam a vida $e$ o desenvolvimento de um organismo. Neste caso o homem em seu cenário natural e cultural.). (...) Há todos os estágios entre a natureza virgem e selvagem e a natureza urbanizada, mas, de um modo geral, o homem colocou sua mão sobre o mundo, e o formou, modelou. Em si esse meio é um elemento do patrimônio, herdado de gerações, de gente do campo, de gente de cidades, que construíram um meio ambiente para si, bom ou ruim.",121

Esse processo de construção implica mudanças: Mudanças espaciais e temporais. Alguns autores acreditam que o Brasil, por ser um país jovem, está mais sujeito às mudanças, uma vez que a sua própria cultura seria jovem. Darcy Ribeiro, citado por Lopes ${ }^{122}$ coloca que

"no Brasil, país novo (eternamente adolescente), a ânsia de libertação do colonialismo cultural adquire uma dupla dimensão: de um lado o fantasma universal da cultura de massas, de outro, o fantasma nacional da 'metrópole'. De certa forma retrata uma espécie de culto tardio às relações entre colonizador e colonizados, que são sempre amargas."

\footnotetext{
${ }^{121}$ TOLEDO. Bem cultural e identidade cultural, Revista do Patrimônio Histórico e Artístico Nacional,.n.20, 1984, p.31.

${ }^{122}$ LOPES. A propósito de política cultural, Revista do Patrimônio Histórico e Artístico Nacional, n. 22, 1987, p. 27 .
} 
Essa ânsia de sair do colonialismo cultural pode levar a atitudes equivocadas, tanto por parte das pessoas que são responsáveis pela elaboração e aplicação da legislação brasileira quanto pelas pessoas encarregadas de difundir as idéias (a imprensa, por exemplo) e até mesmo de executá-las (os empresários, por exemplo). Atitudes equivocadas que poderiam ocorrer na execução de uma legislação ambiental elaborada de forma simplista, como se conservacionismo fosse a única e melhor solução. Ou acreditar que educação ambiental é solução a curto prazo. Faz-se necessário compreender e colocar em prática políticas que sejam duradouras, e não apenas aquelas que estejam vinculadas à bandeira do partido político que está no comando hoje, e que, após as próximas eleições, todo o trabalho realizado será ignorado e substituído por outro, destacado agora por uma outra sigla partidária. Quando se trata de meio ambiente e sobretudo de preservação (tanto cultural quanto ambiental), é extremamente importante a conscientização de que são trabalhos realizados a médio e longo prazo, que consciência ambiental não se adquire da noite para o dia, mas que é extremamente importante para garantir o futuro dos bens culturais. Este trabalho de educação não se deve restringir aos meios acadêmicos, mas tampouco aos cidadãos comuns. É uma tarefa que precisa ser realizada tanto pelas Universidades - sobretudo na formação de profissionais cada vez mais capazes de atuar na área tanto com competência profissional quanto com sensibilidade e comprometimento - mas também pela imprensa na divulgação desses trabalhos e no sentido de esclarecer a comunidade em geral sobre a importância da preservação dos bens culturais para uma sociedade. Aos governantes cabe oferecer condições para a realização do processo como um todo, e à comunidade cabe cobrar desses governantes que cumpram estas metas, estabelecidas por ela mesma.

No Brasil, não existe de fato uma consciência popular com relação aos seus direitos; muitas das vezes, nem sequer com relação aos seus deveres, já que nem sequer a legislação é conhecida por uma grande parcela da população. No dizer de Ab'Saber, do outro lado está a sociedade, com suas aspirações e expectativas que nunca são contempladas pelos técnicos e cientistas, uma vez que estes "se esquecem de uma série de coisas que são fundamentais na problemática de sobrevivência dos grupos carentes, a grande maioria na população deste país: $70 \%$, segundo Hélio Jaguaribe”. ${ }^{123}$

\footnotetext{
${ }^{123}$ Ab'SABER. Patrimônio natural, Revista do Patrimônio Histórico e Artístico Nacional, n. 22, 1987,.p.220.
} 
Tal fato pode ser identificado na região de Serra da Mesa. O poder público, munido de suas atribuições, delibera sobre o futuro da região, e, através de seus técnicos e administradores, implementa alterações importantes na paisagem, na economia, enfim, na dinâmica regional, sem considerar se tais mudanças são efetivamente positivas para a população local, ou se há, por parte desta, interesse efetivo no processo que se instala.

\subsection{A Área do Empreendimento: Características Gerais:}

Trata-se de uma região onde se pode constatar a importância do patrimônio natural e paisagístico regional para a população local, mesmo porque era exatamente esse elemento que estava em iminência de ser destruído. Em verdade, as paisagens que se perderam com a construção da represa da Usina de Serra da Mesa constituíam-se num patrimônio cultural, uma vez que, as experiências vivenciadas nesses lugares foram a base de toda uma forma de vida. Como já foi dito, trata-se de uma região que foi

"ocupada pela colonização a partir das atividades minerais no século XVIII, a área se integra ao movimento de expansão das fronteiras coloniais ${ }^{124}$, que acabou por definir a maior parte do atual território brasileiro." "125

De acordo com Chaim,

"pelos limites estabelecidos no Tratado de Tordesilhas, a fronteira oeste do Brasil seria limitada ao norte em Belém, no Pará, e ao sul em Laguna - Santa Catarina. O território pertencente ao atual Estado de Goiás ficaria, desta maneira, situado em sua maior parte além desta fronteira, em terras que seriam espanholas.

“ Conhecida no século XVIII como 'Minas dos Goyazes', incorporou-se aos vastos domínios portugueses graças à ação

\footnotetext{
${ }^{124}$ Sobre o assunto, ver a obra de Basílio de Magalhães, Expansão geográfica do Brasil colonial., 1978.

${ }^{125}$ UNIVERSIDADE FEDERAL DE MINAS GERAIS. Salvamento histórico-arqueológico na área a tingida pela represa da usina de Serra da Mesa - Goiás. Relatório Final, v. 1, 1998, p.9.
} 
dos bandeirantes paulistas, o que foi posteriormente ratificado pelo tratado de Madri." 126

É uma região de grande expressividade e imponência paisagística, onde a natureza apresenta-se de forma grandiosa. O seu relevo é constituído, em sua maior parte, por planaltos, cujas serras existentes são de modesta altitude; neste local, destacam-se os planaltos residuais do interflúvio Araguaia-Tocantins. Na área da pesquisa, destacam-se a Serra da Mantiqueira, a Serra da Mesa e a Serra Negra, cujas altitudes máximas ficam em torno de $600 \mathrm{~m}$.

O clima goiano apresenta-se como sendo o clima predominante na Região Centro-Oeste: clima tropical-quente-subúmido, e estende-se por quase toda a área de cerrados, tanto em terrenos cristalinos de topografia semiplana, quanto nas áreas mais acidentadas. Sua característica mais marcante é a freqüência quase diária de temperaturas altas, sendo que nos meses mais quentes (setembro e outubro) são muito freqüentes máximas diárias superiores a $38^{\circ} \mathrm{C}$, alcançando, às vezes, valores superiores a $40^{\circ} \mathrm{C}$. Neste tipo climático, o período de insuficiência de chuva dura normalmente de 5 a 7 meses, dos quais 4 a 6 são muito secos (inverno - primavera). A estação úmida é mais curta e suas chuvas são ainda mais concentradas no verão, época de enormes excedentes de água, de solos saturados de umidade e de grandes enchentes fluviais.

Quanto à hidrografia, pode-se constatar que, na Região Centro Oeste, o Planalto Central brasileiro e as chapadas constituem os mais importantes dispersores da rede hidrográfica brasileira, de tal forma que se encontram aí grandes extensões das bacias Amazônica, Tocantina e Platina, e, com uma área mais inexpressiva, acha-se também a bacia Sanfranciscana. ${ }^{127}$ A área da pesquisa concentra-se na bacia do rio Tocantins, o mais importante curso d'água da região em estudo, onde se localiza a Usina Hidrelétrica de Serra da Mesa.

Dentro do conjunto do território goiano, a área em que se constituiu a represa de Serra da Mesa, destaca-se como uma região de grande expressividade também do ponto de vista cultural, apresentando várias ocupações pré-históricas, com um grande número de grupos

\footnotetext{
${ }^{126}$ CHAIM. Aldeamentos indígenas (Goiás, 1749-1811), 1983, p.15.

${ }^{127}$ Sobre a caracterização das condições naturais da região Centro-Oeste, e por extensão do estado de Goiás, ver a publicação do IBGE: Geografia do Brasil, região Centro-Oeste, vol.1, 1989.
} 
indígenas, como os Gê, os Avá, os Caiapós e os Crixás,. mas tendo sido também palco do contato entre as três grandes etnias formadoras da população brasileira.

De acordo com Magalhães ${ }^{128}$, o expansionismo português para o interior do país começou já no século XVI, com o início do ciclo das Entradas,(ou bandeirismo) ${ }^{129}$, embora a efetiva ocupação da região tenha ocorrido durante o século XVIII, impulsionada por interesses mercantilistas da Coroa portuguesa pelos metais preciosos. Para Chaim ${ }^{130}$,

"a figura desses bandeirantes preadores, cuja caça aos silvícolas levava no bojo simultaneamente a conquista do território e a esperança só mais tarde realizada do descobrimento das riquezas minerais, impressiona mais negativamente do que positivamente. Eram acusados de serem sobretudo destruidores. (...) Em território goiano, já haviam dizimado grupos tribais pacíficos como os Goya e Crixá nos séculos anteriores ao XVIII.”.

A dizimação dos povos indígenas em território goiano é um dos fatos mais marcantes da ocupação da região. É um erro no entanto, acreditar que todas as nações indígenas eram pacíficas e por isso foram exterminadas. Uma das tribos mais cruéis, citadas inúmeras vezes pelos mais diversos autores é a dos Avá-Canoeiro, considerados como sendo um povo extremamente violento:

"Nação cruelíssima, belicosa, e que não sabe fugir, resistindo nos seus combates até morrer, investindo furiosamente as mesmas mulheres e cães bravos que trazem consigo: giram em canoas que fazem, pelos rios Tocantins, Paraná, Manoel Alves, Barra da Palma, onde têm feito muitos estragos, ainda que se diz terem a sua principal aldeia entre as serras que ficam ao lado do Duro, onde têm estabelecimento, em que da nossa arte se não tem chegado."

\footnotetext{
${ }_{128}^{128}$ MAGALHÃES. Expansão geográfica do Brasil colonial, 1978, p.14.

129 "O nome 'bandeira' provem da mesma bandeira - flâmula ou estandarte - que essa tropa carregava, insígnia de brasão de armas ou da coroa real. (...) Muitas tinham regimento oficial determinando seus comandantes, os poderes de que dispunham, os objetivos a que se propunham etc... Mas raras foram essas bandeiras regimentadas e muitíssimo mais comuns foram as de caráter informal, às quais se deu no nome de 'entradas'. In: BERTRAN. História do homem e da terra no Planalto Central, 1994, p. 31.

${ }^{130}$ CHAIM. Aldeamentos indígenas- (Goiás: 1749-1811), 1983, p.19.

${ }^{131}$ TELES, citado em: UNIVERSIDADE FEDERAL DE MINAS GERAIS. Salvamento histórico arqueológico na área atingida pela represa da Usina de Serra da Mesa - Goiás, 1998, p.48.
} 
Os Avá-Canoeiro permaneceram na região pelos séculos adentro, persistindo talvez pela sua própria hostilidade. O último grande confronto, segundo a tradição oral local ocorreu no início da década de 1960, após uma série de conflitos pela posse da terra indígena pelos novos colonizadores. $\mathrm{Na}$ atualidade, na área de Serra da Mesa, são os descendentes desse povo o único grupo indígena que ocupa a região, e está reduzido a seis pessoas, comprometendo o futuro da tribo.

Para Tiballi ${ }^{132}$,

\begin{abstract}
"o significativo número de índios que habitavam o centro-oeste brasileiro, quando da chegada dos primeiros brancos colonizadores na região, não permite que se fale em início de povoamento de Goiás no século XVIII. O território goiano já era povoado de norte a sul, por diferentes tribos indígenas que aqui chegaram muito antes deste período."
\end{abstract}

De acordo com o mapa 03, pode-se verificar a localização provável das principais tribos em Goiás, no início da exploração colonizadora.

"[ Bueno, o Pai] era paulista e foi quem primeiro deu notícia da existência do ouro na região de Goiás, no rio dos Aracis ou Araes, donde trouxe dez oitavas desse metal, com as quais foi feita uma coroa para Nossa Senhora da Penha de Sorocaba." ${ }^{, 133}$

Com a (re)descoberta do ouro, no início do século XVIII, pela Bandeira de Bartolomeu Bueno da Silva, conhecido como o Segundo Anhangüera, (fato ocorrido em 1726, em Serra Dourada, divisa de Uruaçu, Pilar de Goiás e Amaro Leite), desencadeou-se o processo de povoamento da região por populações heterogêneas, provenientes dos mais diferentes lugares do país.

\footnotetext{
132 TIBALLI. A expansão do povoamento em Goiás- século XIX, 1991, p.14.

${ }^{133}$ FRANCO, citado em: UNIVERSIDADE FEDERAL DE MINAS GERAIS. Salvamento histórico arqueológico na área a ser atingida pela represa da Usina de Serra da Mesa - Goiás, 1998, p. 35.
} 
Figura 03: Nações Indígenas em Goiás - Século XVIII

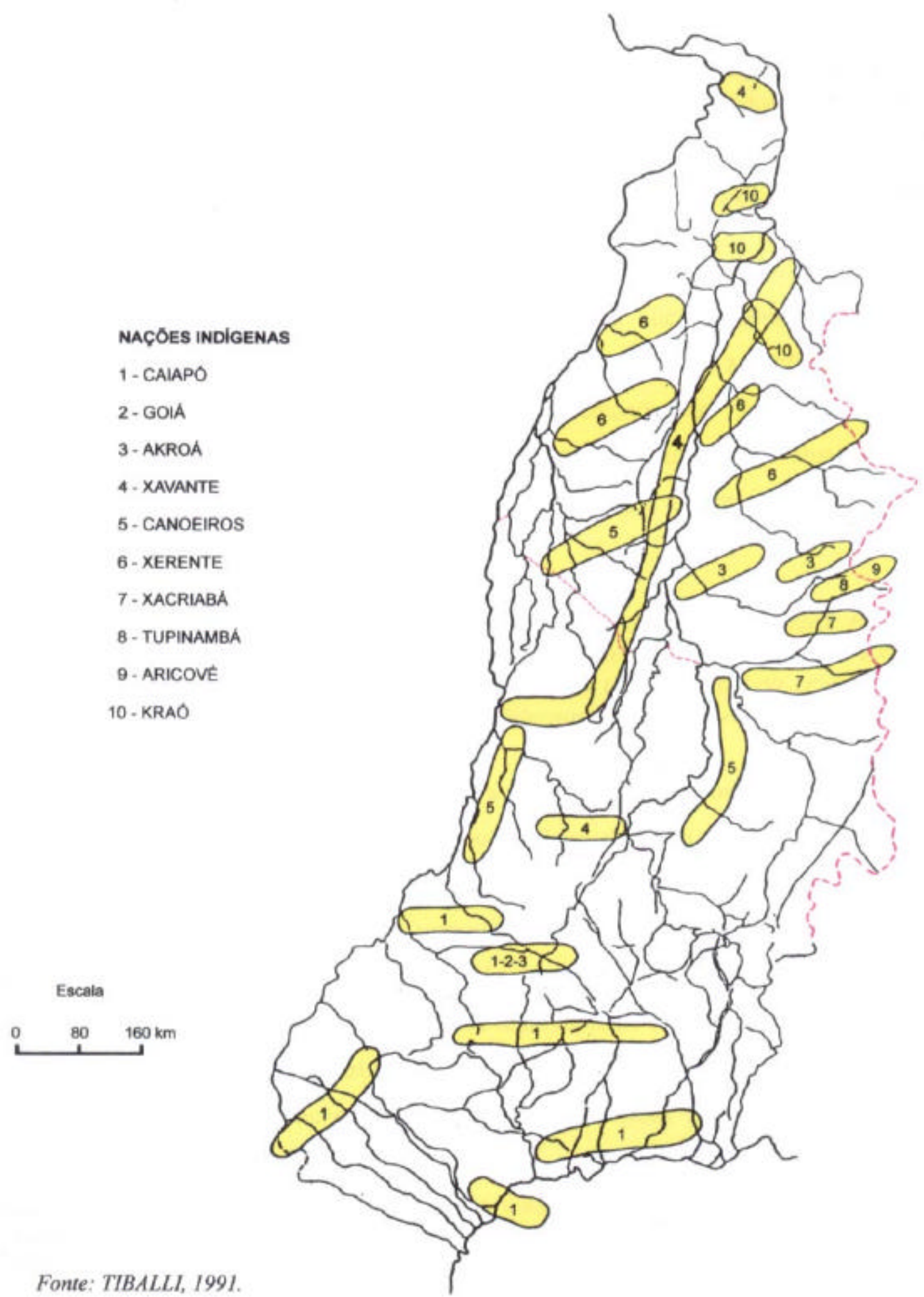

Fonte: TIBALLI, 1991. 
O início do povoamento colonial em Goiás deu-se

"como o das demais áreas de exploração aurífera, se fez. através de 'arraiais', sob a forma de ilhas, núcleos mais ou menos isolados uns dos outros, às vezes enquadrados dentro de verdadeiros arquipélagos.

"O critério para o aparecimento desses arraiais foi $o$ ouro e a água. Voltados para a maior rentabilidade no menor espaço de tempo, a vida nesses lugares era áspera e por vezes violenta. As minas goianas foram exploradas por processos rústicos e penosos, sendo usadas para este fim turmas consideráveis de escravos." $" 134$

De acordo com Tiballi ${ }^{135}$, “dos 54 arraiais existentes em Goiás no ano de 1809, apenas 9 não surgiram da extração aurífera." Diversos e importantes núcleos urbanos formaram-se nessa época na região de Serra da Mesa, sobretudo nas décadas de 1730 a 1750, em conseqüência do fato de novas minas terem sido descobertas nas imediações do rio Tocantins. Alguns deles desenvolveram-se em cidades e outros desapareceram, constituindose atualmente apenas em vestígios. Podem-se destacar dentre eles: o Arraial de Água Quente, surgido em 1733, e que, segundo Palacim ${ }^{136}$, apresentava-se como

"um dos arraiais de grande densidade mineira. Ficava na região da bacia do Tocantins e rotas das divisas baianas. Esta mina, como as demais da região, era tão rica que ao criarse o imposto da capitação foi-lhe determinado uma taxa mais alta por escravo."

Água Quente apresenta-se hoje apenas como vestígio do arraial dinâmico que foi, mas como se encontra fora da área de inundação da represa de Serra da Mesa, não se deu o procedimento de pesquisa, visando ao salvamento arqueológico. Já o arraial de Crixás, surgido em 1734, desapareceu completamente, dele não restando nenhum sinal digno de nota. Data dessa época também o arraial de Traíras (1735), que hoje é importante centro turístico regional, e impressiona pela beleza das ruínas das construções, ainda relativamente bem preservadas. A atual cidade de Niquelândia, importante centro urbano regional, foi fundada em 1735, com o nome de São José do Alto Tocantins; guarda poucos indícios do período colonial. Também outro importante centro urbano regional, surgido em 1740, é a atual cidade de Cavalcante.

\footnotetext{
${ }^{134}$ CHAIM.. Aldeamentos indígenas (Goiás: 1749-1811), 1983, pág.24-25.

135 TIBALLI. A expansão do povoamento em Goiás, séc. XIX, 1991, p.22.

${ }^{136}$ PALACIM.. Goiás 1722-1822 - estrutura e conjuntura numa Capitania de Minas, 1972, p.18.
} 
Ainda na região destaca-se o surgimento dos arraiais de Maranhão (1730), Pilar (1741) e Cocal (1749), além de alguns cuja data não se pode precisar, como o arraial de Santa Rita, cujos vestígios (bastante expressivos) encontram-se a poucos metros da margem da represa de Serra da Mesa.

"A grande maioria destes núcleos urbanos (...) não passava de pequenos arraiais constituídos de casas de 'adobe' $e$ de 'pau-a-pique' organizadas em ruas mal traçadas, que circundavam uma praça, no centro da qual se localizava uma Igreja. Mesmo as casas cobertas de telhas tinham, em grande parte, as paredes feitas de madeira e barro. Estas construções permitiram a Saint-Hilaire observar em 1819: 'não devemos julgar os povoados do Brasil pelos nossos, pois em geral não passam de um amontoado de casebres miseráveis e de ruas lamacentas'.,"137

De acordo com Chaim,

"a exploração do ouro foi, sem dúvida, a mais importante atividade econômica dos habitantes de Goiás na fase inicial da sua colonização, que decorreu das primeiras descobertas auríferas até 1763. (...) A partir de 1763, vários fatores condicionaram a expansão do povoamento, até então determinado, em território goiano, exclusivamente pela mineração. Foram eles:

decadência da mineração pelo esgotamento das primeiras jazidas, (...)

expansão da pecuária através do estabelecimento de sítios de criação,

necessidade de conter as nações de índios hostis, tendo em vista a efetivação do comércio e da navegação dos rios." "138

Fica claro, a partir de então, que o meio ambiente, com os recursos que ele oferecia, foi direcionando a ocupação da região, e, a partir daí, contribuindo e interferindo na construção das paisagens humanizadas. Fatores como a disponibilidade de água, a ocorrência de recursos minerais, sobretudo o ouro, (embora outras ocorrências também foram importantes, como o salitre, o cristal, etc.), além de condições favoráveis à pecuária e/ou à agricultura, são elementos do quadro natural que aos poucos foram sendo apreendidos pelo colonizador, que através do processo de ocupação foi modificando e redesenhando as paisagens anteriormente encontradas.

\footnotetext{
137 TIBALLI. A expansão do povoamento em Goiás- século XIX, 1991, p.44.

${ }^{138}$ CHAIM. Aldeamentos indígenas (Goiás: 1749-1811).1983, p.29.
} 
Tal fato comprova-se pelo grande número de arraiais que desapareceram com o esgotamento da produção aurífera e a sua gradativa substituição por outras atividades econômicas - embora bem menos significativas - como a agropecuária e os engenhos. Modificações expressivas foram ocorrendo na paisagem local, para inserção dos diversos processos produtivos. A mineração, sobretudo, tem como característica marcante a alteração da paisagem - em maior ou menor escala - dependendo das técnicas que são utilizadas no processo.

"As formas de mineração e apuração do ouro variavam, consideravelmente, conforme o tipo de formação aurífera que se devia explorar. Saint-Hilaire classifica as 'lavras' - nome dado pelos mineiros a toda exploração aurífera organizada, em contraposição ao garimpo - em 'mineração de cascalho' $e$ 'mineração de morro', segundo se tratasse de jazidas de aluvião em que o ouro se encontra depositado entre seixos de areia, ou de jazidas em que o ouro permanece ainda no que Eschwege chama de 'rocha matriz'.,"139

Um dos exemplos mais significativos e comuns de alteração da paisagem é a construção de barragens em alguns rios, para proceder-se ao desvio dos seus cursos, e a partir de então efetuar a mineração no seu leito. Sinais de várias dessas barragens, construídas com tecnologia simples e com os recursos disponíveis nas suas proximidades foram encontradas em diversos rios da região, e até mesmo no rio Maranhão, segundo maior curso d'água da área, principal formador do rio Tocantins.

No entanto, a produção aurífera começou a declinar rapidamente.

"A medida que as lavagens nas cabeceiras ou nas encostas foram trazendo novos elementos sedimentares, o cascalho virgem foi ficando mais profundo e difícil de atingir. Nalguns lugares, depois de um século de mineração, tinha sobre si uma camada de areia, pedras e lama de mais de quinze metros." 140

A mineração passa a tornar-se dispendiosa tendo em vista o pequeno retorno obtido.

\footnotetext{
${ }^{139}$ PALACIN. Goiás 1722-1822 - Estrutura e conjuntura numa Capitania de Minas. Goiânia, 1972, p. 67.

${ }^{140}$ PALACIN. Goiás 1722-1822 - Estrutura e conjuntura numa Capitania de Minas, 1972, p. 68.
} 
"A nova Capitania de Goiás, que sofrera na primeira metade do século XVIII uma enorme influência de povoadores, devido à corrida do ouro, já na segunda metade do mesmo século começou a esvaziar-se e a declinar.

'Entre 1783 e 1804, a diminuição de população na Capitania foi da ordem de 20 por cento. As impressões de Pohl e Saint-Hilaire reforçam a idéia do abandono da Capitania por parte de grandes massas humanas, sobretudo branca, ao acentuar-se a decadência da mineração, crise que no tocante à população só começou a ser superada nos primeiros anos do século XIX, graças às atividades agropastoris, tendo também contribuído para isso o aldeamento ${ }^{141}$ de várias tribos hostis." 142

Para diversos autores, o século XIX foi um período de decadência da economia goiana, ao mesmo tempo em que se implantava um processo de ruralização da economia, como substituição à produção aurífera. De acordo com Tiballi ${ }^{143}$ “"no início do século XIX os núcleos urbanos não apresentavam progressos em Goiás. Onde não havia decadência reinava a estagnação. As Exceções eram raras e insuficientes para dinamizar a vida urbana na Capitania." As dificuldades enfrentadas pela atividade mineratória não eram de fato poucas:

"da Estatística da Província de Goiás de 1825 constam as dificuldades que passava a mineração: poucos braços para o trabalho e contrabando incontrolável. Nesse ano, havia na Província 41 lavras efetivamente trabalhadas, 232 abandonadas e inúmeras faisqueiras. Em 1830, o contrabando não havia diminuído. Segundo o Ofício sobre o Estado Político $e$ Econômico de Goiás, os minerdores fugiam sistematicamente da Casa de Fundição, extraviando grandes quantidades do metal." 144

Ainda de acordo com a Tiballi ${ }^{145}$, o desenvolvimento da atividade pastoril em Goiás está relacionado a uma conjunção de quatro fatores principais: a liberação da mão de obra da mineração, a descapitalização da população, a disponibilidade de terras e a posição marginal

\footnotetext{
141 "Teve início com este Governador, auxiliado por sertanistas, pagos com dinheiro arrecadado das populações dos diferentes arraiais, a obra da redução das tribos hostis, que serão alojadas nos aldeamentos Reais.(...) Nos aldeamentos formados em Goiás no século XVIII, vigorava regime de trabalho semelhante ao das missões jesuíticas(...) in: CHAIM. Aldeamentos indígenas (Goiás, 1749 -1811), 1983, p. 108 e 127.

${ }_{142}$ CHAIM. Aldeamentos indígenas (Goiás, 1749- 1811), 1983, p. 30.

${ }^{143}$ TIBALLI. A expansão do povoamento em Goiás - Século XIX, 1991, p. 56.

${ }^{144}$ UNIVERSIDADE FEDERAL DE MINAS GERAIS. Salvamento histórico arqueológico na área atingida pela represa da usina de Serra da Mesa - Goiás.1998, p.55.
} 
de Goiás no quadro da economia colonial portuguesa. Neste caso, esta posição marginal explicar-se-ia sobretudo pela posição interiorana da região, gerando grandes dificuldades para a dinamização dos setores de transporte e comunicação. Esta situação de isolamento é destacada na obra de Luís Palacin ${ }^{146}$. Segundo este autor, a média de uma viagem para transporte de carga de Goiás ou Mato Grosso até São Paulo, por exemplo, duraria em média dois anos, contando-se ida e volta.

Por tudo isso observa-se que a dinamização da economia goiana se tornava difícil, e as atividades agropastoris também enfrentaram dificuldades.

"As tendências todas da população se iam dirigindo para a lavoura e para a indústria pastoril, que as lavras iam sendo abandonadas e os arraiais despovoados dos homens abastados os quais procuraram cômodas localidades para fundarem estabelecimentos de lavoura e criação" ${ }^{\text {147 }}$.

Em 1822, dá-se a extinção do regime de sesmarias e nenhuma outra legislação regulamenta a posse de terras devolutas no país, até a promulgação da Lei de Terras, em 1850. No entanto, a legislação não foi suficiente para garantir a ocupação dessas terras. De acordo com Tiballi ${ }^{148}$,

"o alto custo da medição de terras e a inexistência de pessoas preparadas para esse fim aliado às exorbitantes taxas cobradas para o registro paroquial, fizeram com que a intenção de legitimar e registrar as propriedades rurais fosse inviabilizada. (...) A posse era praticada por quem por ela se interessasse, e os limites da propriedade eram definidos pela capacidade financeira daquele que ocupava o terreno. A extensão das terras ocupadas seria tanto maior quanto mais escravos ou recursos tivesse o posseiro para explorá-la. Na condição de grandes proprietários estavam os fazendeiros, que poderiam explorar suas terras com a lavoura, a criação de gado vacum ou cavalar ou com engenho de açúcar."

Outra dificuldade que se há de considerar quanto à produção agropecuária é que

"as propriedades desmembravam-se e reglutinavam-se a cada geração. Sendo muitos os herdeiros, retalhavam-se as fazendas em minifúndios, os quais, em razão da baixa

\footnotetext{
145 TIBALLI. A expansão do povoamento em Goiás, séc. XIX, 1991, p.56.

${ }^{146}$ PALACIN. Goiás, 1722-1822, estrutura e conjuntura numa Capitania de Minas, 1972, p. 145.

${ }_{147}$ PALACIN. Goiás, 1722-1822, estrutura e conjuntura numa Capitania de Minas, 1972, p. 150.

${ }^{148}$ TIBALLI. A expansão do povoamento em Goiás, séc. XIX, 1991, p.58.
} 
fertilidade natural do solo, também não duravam muito, passando a recuperar-se em fazendas médias, seja por venda ou por abandono.",149

Ainda sobre esta questão, na avaliação de Tiballi, “em Goiás, a ocupação legal ou através da compra e da venda só irá efetivar-se no final do século XIX quando se inicia a ocupação capitalista da terra e esta se transforma em mercadoria." ${ }^{150}$ De qualquer forma, se, durante o período colonial, nem mesmo no auge da produção aurífera Goiás conseguiu tornar-se um pólo econômico dinâmico, também não conseguiu sê-lo na fase que se seguiu. A ocupação populacional caracteriza-se por apresentar um contingente considerado reduzido, dada a vastidão territorial, o que é agravado pela presença de grande número de latifúndios ${ }^{151}$. Nem mesmo a ação do governo federal, no sentido de liberar incentivos fiscais para a região, foi suficiente para mudar esse quadro. A construção de Brasília gerou um certo incremento populacional à região, bem como foi considerada como sendo um fator importante de integração regional. No entanto, na prática, verifica-se que a influência de Brasília sobre a região norte do estado de Goiás é ainda pequena. Talvez esse fato possa ser explicado pelo papel político-elitista representado pela capital federal. Já as relações econômicas das cidades mais afastadas, como por exemplo as da área desta pesquisa, se dão de forma muito mais concreta com a cidade de Goiânia do que com Brasília.

Embora tenha havido um esforço do governo em promover uma

"crescente integração da economia e do território nacionais e a conseqüente dissolução das 'economias regionais' , ou seja, das 'regiões econômico-sociais' vinculadas ao período primário-exportador da economia brasileira dominante até fins do século XIX"152,

na área em questão observa-se que esta integração não se concretizou de forma ampla. Mesmo considerando-se que o papel do Estado tenha sido decisivo para o processo de ocupação da região, o Centro Oeste e Goiás ainda figuram atualmente entre os espaços ainda pouco ocupados do território nacional. O próprio fato de a economia regional ter sido inserida em

\footnotetext{
${ }^{149}$ UNIVERSIDADE FEDERAL DE MINAS GERAIS. Salvamento histórico arqueológico ..., 1998, p.57.

${ }^{150}$ TIBALLI.. A expansão do povoamento em Goiás, séc. XIX, 1991, p.58.

${ }^{151}$ De acordo com o INCRA - Instituto Nacional de Colonização e Reforma Agrária, só a Região Centro Oeste apresenta um total de cerca de 15.600 propriedades com mais de 1000 ha, sendo a maioria improdutiva.

${ }^{152}$ PERIDES. Integração territorial e regionalização, Revista Orientação, nº 9, 1992, p.32.
} 
diretrizes de desenvolvimento regional enquanto área de expansão de fronteiras de produção agropecuária do país, levou a sua produção regional a estar fortemente ligada ao setor primário, fato que já se mostra como um indício das diferenças marcantes apresentadas pelo Centro-Oeste - e particularmente por Goiás - em relação ao Centro-Sul do país.

"Sem dúvida, a evolução demográfica do Centro-Oeste reflete o seu processo de estruturação regional, cuja indução se deu, de um lado, pela ação governamental - centrada no deslocamento populacional para a região, a partir da incorporação de terras agrícolas, abem como da implantação de uma rede de rodovias-tronco, sobretudo na década de 70, objetivando caracterizá-la como região produtora de alimentos e como princiapal via de ocupação da Amazônia - e, de outro lado, pelos influxos originados, principalmente, na Região Sudeste, tornando-a caudatária de influências econômicas e demográficas de áreas vizinhas. "153

A produção agropecuária regional é hoje muito expressiva, não apenas pelo efetivo aumento da área ocupada por essa atividade mas, sobretudo devido a de modernização do processo produtivo verificado a partir do grande aporte de incentivos fiscais e da expansão da agroindústria na economia regional.

"A extraordinária incorporação de espaços à agropecuária, estimulada pelos incentivos fiscais e financeiros, já se verificou num contexto de progressiva articulação da agricultura com o setor dominante da economia, o que respondeu pelo emprego maciço de maquinaria e de insumos de origem industrial, um processo acelerado de modernização da agricultura regional. (...) Na região como um todo, o volume de crédito carreado para a agropecuária quintuplicou, de 1970 a 1980, e deixou patente o caráter seletivo de sua distribuição, uma vez que somente um quinto dos produtores recorria a financiamento bancário, ao final de uma década, na qual o crédito rural constituiu o principal mecanismo de estímulo à expansão da atividade agrária" ${ }^{, 154}$.

\footnotetext{
${ }^{153}$ AJARA. População. In: FUNDAÇÃO DO INSTITUTO BRASILEIRO DE GEOGRAFIA E ESTATÍSTICA. Geografia do Brasil , região Centro Oeste. 1988, p. 123.

${ }^{154}$ MESQUITA. Agricultura In: FUNDAÇÃO DO INSTITUTO BRASILERIO DE GEOGRAFIA E

ESTATÍSTICA. Geografia do Brasil: região Centro-Oeste, 1989, p. 148-149.
} 
Verifica-se assim que a modernização agrícola e o desenvolvimento da produção não atingiu a todos os produtores da região, mas efetivamente concentrou-se nos grandes proprietários e naqueles mais capitalizados. Dessa forma, o pequeno produtor continuou à margem do processo produtivo, mantendo a condição verificada pela pesquisadora durante os trabalhos de campo: os produtores mais descapitalizados enfrentam grandes dificuldades inerentes ao processo produtivo agrícola, e, sem apoio institucional, mantêm a si mesmos e às suas propriedades em condição próxima da penúria.

Além dessas características, há que se observar as condições em que se desenvolve a indústria na área de estudo. O setor industrial na região Centro Oeste apresenta-se de forma pouco expressiva - compondo o PIB regional em proporção menor do que a agropecuária ${ }^{155}$ e está vinculada a dois grandes eixos: à agroindústria e ao beneficiamento de minerais, embora se possa encontrar também indústria editorial e gráfica, a de madeira, couros e peles, como concentradoras do maior contingente de pessoal ocupado no setor. As maiores aglomerações industriais estão junto às cidades de Anápolis e Goiânia. Na área da pesquisa propriamente, destacam-se a SAMA S/A Mineração de Amianto, que atua no município de Minaçu e absorve expressiva mão-de-obra local, sendo uma das maiores indústrias de amianto da região. No município de Niquelândia, o destaque é para a Codemin, empresa mineradora de ferro e níquel, ligada à Níquel-Tocantins, do grupo Votorantin, que também ocupa considerável mão-de-obra local. Estas duas empresas merecem expressão relevante para a economia regional, destacando os municípios onde atuam dentro do contexto das cidades locais.

\subsection{A construção da paisagem e da cultura em Goiás}

Todas as colocações anteriores sobre o espaço de Goiás e a área do empreendimento são passíveis de consideração do ponto de vista de que, em cada situação, está sendo discutida a construção do espaço numa análise temporal. Portanto, em última instância, verifica-se como o território foi sendo modelado pelas diferentes formas de ocupação que aí ocorreram.

\footnotetext{
${ }^{155}$ Sobre o tema, ver o capitulo “Indústria”, in: Geografia do Brasil: região Centro-Oeste, 1989, p.170-188.
} 
Toda a trama de relações entre as sociedades diferentes que aí se instalaram, seus diferentes objetivos, técnicas, produções, tudo, ao longo do tempo, somar-se-á para formar nada menos do que a cultura regional.

Desde o período pré-colonial, quando a região era habitada apenas pelos indígenas, a paisagem regional vem se impregnando de elementos culturais. Essa paisagem vai registrando, ao longo do tempo, as ocupações sucessivas que vão ocorrendo no território, e cabe ao investigador da arqueologia histórica identificar e analisar essas manifestações culturais sob a forma de vestígios, denominados de cultura material.

No caso de Serra da Mesa, como já foi dito, a ocupação indígena remanescente restringe-se a uma tribo composta por apenas seis indivíduos, sob a responsabilidade da FUNAI e na iminência de se extinguir, visto que as duas únicas crianças do grupo são irmãs, e, portanto, não há premissas de procriação no futuro, a não ser que novos indivíduos sejam contactados. Como se trata de remanescentes de um grupo bem maior, há indícios de que possam existir outros representantes, visto que o grupo original se dissipou durante o início da década de 60, quando se tornaram nômades para fugirem dos ataques de fazendeiros da região, que procederam sucessivos massacres, dizimando quase que por completo os índios que insistiam em permanecer no local.

No entanto, a expressão material indígena é muito pequena, sobretudo pelo fato dos seus remanescentes não se fixarem, o que impossibilita o contato interétnico na atualidade, com exceção do grupo já citado, e que se encontra sob a guarda da FUNAI.

De qualquer forma, o elemento indígena que viveu nestas regiões criou uma cultura própria, firmada sobretudo pela necessidade de sobrevivência. As manifestações de cultura material que puderam ser encontradas na região da UHE de Serra da Mesa podem ser classificadas em duas categorias: ou são expressões materiais de culturas pré-históricas ou de culturas históricas. O que irá diferenciar uma da outra é o período em que estes bens foram produzidos. Aqueles vestígios muito antigos, cuja datação - mesmo relativa - remontar a alguns milhares de anos, até aproximadamente 1.500, serão considerados como pré-históricos. Posterior a isso, são históricos. No entanto, nem sempre a datação é um elemento fácil de ser identificado, em se tratando de uma área ainda pouco pesquisada e com sucessivas ocupações, como é o caso da área em questão, onde moraram vários grupos de pessoas em aldeias ou em 
pequenos acampamentos. Os grupos mais antigos viviam da caça e da pesca e em geral, não conheciam a cerâmica. Os mais recentes fabricavam utensílios cerâmicos e conheciam, provavelmente, pelo menos um tipo de cultivo. ${ }^{156}$ Durante os trabalhos de campo foram inventariados mais de 30.000 objetos considerados testemunhos arqueológicos. A continuidade das pesquisas será fundamental para se conhecer melhor esse universo, inclusive através do desenvolvimento de dissertações e teses de mestrado e doutorado de novos pesquisadores.

Um segundo momento passível de identificação com mais segurança é o período que corresponde à colonização histórica. A chegada do colonizador na região muda completamente as relações estabelecidas até então entre o homem e a natureza. Pela sua característica predadora, o colonizador estabelece uma relação de posse para com a terra, e ingressa o terceiro elemento, formador da cultura brasileira: o escravo africano, que será a mão-de-obra fundamental para a exploração das minas de ouro, já que o elemento indígena regional apresenta-se quase sempre como o selvagem de difícil aculturamento.

“Em Goiás, houve tribos que opuseram forte resistência durante mais de um século. (...) Por motivo das hostilidades no norte, pessoas das mais equânimes pressionavam o governador para que desse ordem de matar a todo início acima de dez anos. A mesma opinião recolheu Pohl, quase um século depois: os indios eram para os moradores apenas uns 'bichos' que deveriam ser exterminados, para ocupar suas terras, as mais férteis da Capitania." 157

Quanto aos escravos e negros nesta Capitania, ainda é de Palacin a melhor descrição:

"O dito popular do século XVIII de ser o Brasil o 'inferno dos pretos, o purgatório dos brancos e o paraíso dos mulatos', deve ter tido sua plena realização, no tocante aos pretos, sobretudo nas minas. Aos outros males da escravidão, aqui vinha somar-se a dureza do trabalho inexoravelmente exigido até a morte."

\footnotetext{
${ }^{156}$ FURNAS CENTRAIS ELÉTRICAS S.A. A usina hidrelétrica Serra da Mesa e o meio ambiente, 1996, p.32.

${ }^{157}$ PALACIN. Goiás 1722-1822 - Estrutura e conjuntura numa Capitania de Minas, 1972, p. 96-97.
} 
Ainda de acordo com este autor, as condições sub-humanas de trabalho nas minas alimentou a proliferação dos quilombos na região, tornando-se um elemento comum no período colonial. Palacin coloca que " $D$. José de Almeida interpreta as fugas: 'constando-me das contínuas deserções de negros cativos que impelidos dos seus perversos costumes procuram viver impunemente nos matos..." De fato, mesmo muitos séculos depois, pode-se constatar a importância dos quilombos na cultura local. Durante a pesquisa na área da UHE de Serra da Mesa, foram citados por vários moradores histórias e lendas referentes a comunidades negras que viveram em antigos quilombos, e a partir da literatura sobre o tema o grupo de pesquisa intentou localizar algum deles, no que resultou um trabalho infrutífero. Essa dificuldade pode ser creditada ao fato de que os quilombos constituíam-se em comunidades que procuravam, obviamente, evitar o contato com os demais elementos da sociedade, portanto a sua característica principal era exatamente a dificuldade de ser localizado. Além disso, eram comunidades precárias, sem cultura material muito expressiva, que além da precariedade econômica contava com a discrição como elemento fundamental de sobrevivência.

Após o início da decadência da atividade mineratória, a atividade agropastoril foi se firmando, ainda que lentamente, sobrevivendo às dificuldades econômicas e à crise que se estabeleceu em grande número dos núcleos urbanos. Dessa forma, a ocupação inicial do território goiano, que se deu através de dos referidos núcleos urbanos ligados à mineração, passa então a apoiar-se na agricultura e na pecuária, ocorrendo um processo denominado por alguns autores como ruralização da população, expresso pela expansão das propriedades rurais tais como sítios, fazendas e engenhos, ao mesmo tempo em que se dava a decadência de vários povoados.

Em ambos os casos há que se considerar a importância do papel do meio geográfico nesses processos de ocupação do território. Embora a descoberta do ouro na Capitania de Goiás só tenha ocorrido muito depois do início da sua exploração na região das Minas Gerais, tal fato era aguardado com ansiedade pelos bandeirantes e pelas autoridades portuguesas, uma vez que várias lendas e mitos atestavam como verídica a ocorrência de ouro e outras riquezas nos sertões. Corria na época "diversos rumores vindos do vasto desconhecido interior do país

${ }^{158}$ PALACIN. Goiás 1722-1822 - Estrutura e conjuntura numa Capitania de Minas. 1972, p. 92. 
sobre enormes riquezas minerais em ouro e prata, superiores talvez, às do México e do Peru." 159

Ora, a importância do meio e de suas ocorrências minerais foi fundamental para a ocupação efetiva dessa região ainda no período colonial, uma vez que grande parte dessa área era ocupada pela formação de cerrado, denominada pelo colonizador como sertão, deixando transparecer aí a própria dificuldade de ocupação. De acordo com o dicionário Aurélio, o termo sertão serve para designar uma região agreste, distante das povoações ou das terras cultivadas. Tratando-se de um meio bastante inóspito, mesmo nas áreas onde o cerrado dá lugar à mata de transição para a floresta Amazônica, e acrescido a isto o fato de que se trata de uma região interiorana, muito distante do centro político e econômico da colônia, a sua ocupação efetiva provavelmente teria sido adiada não fosse a descoberta do ouro e demais riquezas, bem como a sua aparente abundância (fato este que não se confirmou após iniciada a sua exploração).

A existência de cursos d'água abundantes e perenes também foi fundamental para propiciar a efetivação da colonização do interior do Brasil à época da colônia. Tais atrativos eventualmente causavam a cobiça de outras nações, fato que os portugueses não ignoravam, e tudo fizeram para afastar. Assim, as riquezas - verídicas ou fictícias - do interior do Brasil atraiam a atenção de muitos, e um mecanismo não raro utilizado por Portugal era a confecção de inúmeros mapas, com informações diferentes e/ou contraditórias entre si, buscando com isso confundir e dificultar o acesso de pessoas não autorizadas às áreas ainda pouco exploradas da colônia. De acordo com Bertran ${ }^{160}$,

"a cartografia portuguesa dos Séculos XVI e XVII é, per si, um enigma propositado. Havia os mapas para consumo interno, calcados nas últimas e mais verídicas informações procedentes do ultramar; e os mapas para consumo externo das outras nações européias, ocorrendo ou bem em absolutas vacuidades inúteis - em que enormes escudos das armas de Portugal encobrem vitais informações geográficas - ou bem em erros deliberados de informação."

\footnotetext{
${ }^{159}$ BERTRAN. História da terra e do homem no Planalto Central: eco-história do Distrito Federal: do indígena ao colonizador, 1994, p. 35.

${ }^{160}$ BERTRAN. História da terra e do homem no Planalto Central: eco-história do Distrito Federal: do indígena ao colonizador, 1994 , p. 36.
} 
Verifica-se assim, que a ocupação da região foi se consolidando, e ao meio físico foram sendo acrescidos os elementos culturais típicos dos grupos que aí se assentaram: primeiramente, o indígena e posteriormente o europeu, os escravos e os mestiços oriundos das primeiras.

A atividade pastoril, bem menos rentável que a anterior, era porém mais capacitada para propiciar laços duradouros com a terra e modelar mais lentamente a paisagem, de acordo com as suas características peculiares. Tais fazendas, de acordo com Bertran ${ }^{161}$, não ser limitavam à criação de gado:

\begin{abstract}
"ingênuo seria pensarmos que fossem exclusivas quanto ao gênero de produção: ao lado do curral, vicejava a roça de alimentos e, às vezes, a grande plantação de cana-de-açúcar com o correspondente engenho, produzindo os alimentos mais consumidos nos Séculos XVIII e XIX: a rapadura, a cachaça e as farinhas de mandioca, de milho e, eventualmente, de trigo, além do feijão, do arroz, da criação de porcos e galinhas, todos produtos alimentares, a exceção do fumo de rolo e do 'mamono', cujo óleo usava-se para a iluminação."
\end{abstract}

Esse tipo de ocupação no entanto deixou parcos vestígios arqueológicos para a atualidade. De acordo com Tiballi,

“a formação das fazendas era bastante rudimentar, ficando as exceções para os fazendeiros que exerciam também a atividade comercial e com o lucro melhoravam a arquitetura e a qualidade das construções. (...) Comentando sobre uma destas fazendas Victor Coelho escreveu: 'possuidor de enorme área de terreno, para mais de 9.000 alqueires (45.000 hectares), e muito gado, o fazendeiro João Vilela vive sem conforto algum. (...) São estes os meios de vida daquele sertão: as mulheres tecem; as roças fornecem mantimentos; o porco, banha e carne; as galinhas, ovos e carnes; o gado laticínios. Falta-lhes sal, alguma ferramenta e pouca coisa mais. Para esse suprimento, carregam dois ou três cargueiros e vão a Goyaz, (...) onde vendem a carga e compram o necessário(...). A casa de João Vilela abre uma exceção entre as fazendas daqueles sertões: é

\footnotetext{
${ }^{161}$ BERTRAN. História da terra e do homem no Planalto Central: eco-história do Distrito Federal: do indígena ao colonizador, 1994, p. 159.
} 
coberta de telhas (...) ao lado está a cada do filho de João Vilela, coberta de folhas de buriti."162

De fato, não é comum encontrar-se vestígios de habitações com requintes de arquitetura. Geralmente as construções se perdem no tempo devido à precariedade dos materiais empregados, como o adobe e a cobertura de palhas. Comumente pode-se detectar a presença dos alicerces, geralmente construídos de blocos rochosos, material retirado das áreas adjacentes. Vestígios das áreas de serviços são também comuns: engenhos, monjolos, canais para captação de água, e eventualmente moinhos. Três tipos de evidências aparecem também com frequiência, relacionados à transformação de alimentos: são os fornos, os fogões e as fornalhas. Por outro lado, objetos e utensílios domésticos constituem-se em raridades (especialmente porcelanas e vidros), e quando localizados são pouco elaborados, quase toscos.

Dessa forma, pode-se inferir porque a pesquisa histórico-arqueológica tem apresentado um desenvolvimento e, sobretudo, um interesse menor do que as pesquisas pré-históricas. A despeito de todas as dificuldades para se identificar os vestígios de uma ocupação histórica e associá-los a um determinado período da ocupação do território brasileiro, existem ainda três importantes elementos dificultadores desse processo. São eles:

1. O fato já mencionado de que a legislação brasileira sobre o tema é muito recente, e portanto, não se criou condições de trabalho desejáveis nesse campo. Sobretudo no que tange à questão do cumprimento dessa legislação, uma vez que se não houver fiscalização todo o processo fica dificultado.

2. O fato de que o número de pesquisadores capacitados para desenvolverem este trabalho é muito pequeno, em se considerando a extensão territorial do país e o grande número de sítios arqueológicos a serem pesquisados. $\mathrm{O}$ apoio à pesquisa - seja governamental ou privado - é condição sine qua non para o desenvolvimento e a manutenção de trabalhos, projetos e pesquisas científicas sobre o tema.

3. O fato de que o tema no Brasil ainda está muito restrito aos meios acadêmicos, carecendo de maior divulgação, buscando atingir sobretudo a parcela da população que normalmente não tem acesso a este tipo de informação. A partir daí deveria ser instalado um amplo programa de educação, envolvendo os aspectos ambientais e

\footnotetext{
162 TIBALLI. A expansão do povoamento e Goiás, séc. XIX, 1991, p. 62-63.
} 
preservacionistas do patrimônio cultural, como sendo elementos vitais para a formação de novos cidadãos.

Pode-se, portanto, avaliar a importância e a abrangência do campo que se abre diante dos pesquisadores da área. Não é comum no Brasil ainda a participação da iniciativa privada neste campo de estudos, e quando ocorre, geralmente o enfoque buscado é dado preferencialmente para a pesquisa pré-histórica, buscando o respaldo da mídia, que nos últimos anos tem reforçado a sua divulgação no nível mundial. O interesse popular é normalmente maior para a descoberta de fósseis pré-históricos (de preferência gigantescos), do que para vestígios de utensílios domésticos, por exemplo, principalmente após a exploração do tema por Hollywood.

Os antigos núcleos de povoamento na Capitania de Goiás encontravam-se em condição de quase absoluto isolamento com os centros urbanos mais importantes da colônia, e principalmente dos grandes centros urbanos europeus. Dessa forma, tanto a arquitetura quanto a cultura material sofria as adaptações necessárias às condições de vida impostas pelas condições locais. Sobre a arquitetura bandeirista, os registros e estudos que se tem notícia estão vinculados às regiões mais dinâmicas, sobretudo São Paulo, Rio de Janeiro e Minas Gerais, conhecendo-se muito pouco sobre a região de Goiás. No entanto, infere-se que neste caso, sejam mais comuns as semelhanças do que as diferenças, não devendo ter ocorrido muitas alterações entre um e outro.

De qualquer forma, o território goiano foi sendo modelado ao longo dos anos que se seguiram à sua ocupação num processo lento de construção da paisagem e da cultura, ambos se dando ao mesmo tempo. O espaço vai sendo remodelado na medida que uma nova ordem social vai lentamente sobrepujando a anterior, expressa através de um reordenamento econômico. Este o processo identificado para a área da UHE de Serra da Mesa. 


\section{Capítulo III}

\section{SERRA DA MESA: A CONSTRUÇÃO DE UMA NOVA PAISAGEM}

“A paisagem é uma marca, porque exprime uma civilização; mas também é matriz, porque participa do sistema de percepção, concepção e ação - quer dizer da cultura - que canaliza a relação de uma sociedade com o espaço e com a natureza."

(Augustin Berque) 


\section{SERRA DA MESA: A CONSTRUÇÃO DE UMA NOVA PAISAGE M}

A construção da Usina Hidrelétrica de Serra da Mesa, na região desta pesquisa, implicou uma mudança drástica na paisagem local. A represa da usina submergiu áreas anteriormente ocupadas por fazendas, sítios, estradas, rios, pontes, vales, e outros, substituindo antigas paisagens por um espelho d'água de centenas de quilômetros. Desta forma, as relações entre os habitantes e os seus locais de moradia e trabalho foram rompidas de forma inexorável. Muitos autores têm buscado analisar as relações entre os habitantes e os lugares onde vivem.

É sabido que são criados laços de afetividade à medida que se vivencia um determinado lugar, ou seja, ele passa a ter importância como testemunho dos momentos marcantes da vida das pessoas. Por este motivo, as intervenções de grande vulto, capazes de alterar grandes áreas e paisagens, como a construção de uma usina hidrelétrica por exemplo, são cada vez mais vistas com certas restrições. Busca-se hoje, através dos órgãos empreendedores, incentivar empreendimentos de menor porte, que apresentem menores impactos sociais, econômicos e ambientais. 
A Usina Hidrelétrica de Serra da Mesa é um empreendimento mais antigo; a sua construção iniciou-se em 1978, e por isso ainda não faz parte dessa nova política. É considerada, no entanto, uma das últimas, ou talvez a última grande usina hidrelétrica construída por FURNAS.

\section{O empreendimento de Serra da Mesa e suas justificativas}

O Brasil está vivendo nos últimos meses a pior crise energética de sua história, crise esta que é a consequiência da imprevidência de sucessivos governos, cuja capacidade empreendedora esbarra na competência de gestões pouco comprometidas com o futuro da Nação.

A crise atual foi prevista em incontáveis estudos técnicos sobre o abastecimento de energia, sobretudo nos últimos 5 anos, quando medidas simples como a adoção do horário de verão por exemplo, se tornaram fundamentais, garantindo uma economia da ordem de $20 \%$ em horários críticos, minimizando - mas não afastando completamente - o risco de apagões nas áreas mais urbanizadas do país.

Ocorre que o número de investimentos, sobretudo em infra-estrutura no setor, esteve aquém das necessidades do país. Além disso, as duas dezenas de bilhões de dólares arrecadadas na venda das estatais do setor elétrico, desde o início das privatizações, em 1990, foram utilizadas para abater dívidas, sem a preocupação do reinvestimento.

Dessa forma, optando por cumprir os compromissos com o Fundo Monetário Internacional (FMI), o atual governo, cuja gestão iniciou-se em 1994, vinha fazendo cortes sucessivos no orçamento das estatais de energia, buscando atingir as metas do déficit público.

Com isso, ao deflagrar-se a crise de forma inevitável, o que ocorreu foi um descompasso nas informações, onde a mídia noticiava uma situação beirando o caos e o 
governo tentava minimizar o problema. De fato, nem um nem outro confirmaram-se plenamente. No verão de 2001 e início de 2002, as chuvas ocorreram em abundância, diminuindo os riscos de corte no fornecimento de energia para o período. De qualquer forma, com a necessidade do racionamento, ocorreu um grau de comprometimento no crescimento econômico do país - cujos números são também muito contraditórios - mas, fala-se em algo em torno de 600.000 a 850.000 postos de emprego reduzidos no período, e uma diminuição da ordem de 2 a $4 \%$ da taxa de crescimento do PIB. De fato, só o tempo poderá fornecer dados concretos, mas o certo é que não seria possível o país passar por uma tão grave crise, sem ter o seu crescimento afetado.

Como complicador da situação, é sabido que investimentos feitos agora no setor só apresentarão um retorno palpável após anos de trabalho sério. Uma usina termelétrica necessita de um tempo mínimo de construção de um ano. Já para as hidrelétricas, esse tempo pode quintuplicar, levando-se em conta desde o período dos estudos preliminares até o momento em que ela entraria efetivamente em funcionamento.

Assim; o Brasil, que é um país cujo potencial hidroenergético aproveitável é um dos maiores do mundo, - superior a 53,5 milhões de $\mathrm{kw}^{163}$ - sempre apresentou uma tendência à geração de energia através da hidreletricidade, embora alguns estudos garantam que outras formas de produção poderiam apresentar resultados iguais ou melhores, em termos de custo/benefício. De qualquer forma, o aproveitamento dessa grande reserva energética é uma tendência natural no país, acrescentando-se aí o fato de que com a construção das barragens, há a possibilidade de utilização da água para outros fins - abastecimento, irrigação, recreação e outros usos.

A hidreletricidade começou a ser produzida no Brasil durante os últimos vinte anos do século XIX, no estado de Minas Gerais, através da iniciativa privada. Neste período,

"a capacidade instalada no país ampliou-se 232 vezes, passando de $52 \mathrm{~kW}$ para $12.085 \mathrm{~kW}$, dos quais $5.500 \mathrm{~kW}(46 \%$ do total) eram gerados por usinas hidrelétricas. Nesse período foram instalados serviços públicos de energia em várias cidades, abrangendo iluminação, força e tração elétrica."164

\footnotetext{
163 BRANCO \& ROCHA. Poluição, proteção e usos múltiplos de represas, 1983, P.1.

${ }^{164}$ ROSA. Impactos de grandes projetos hidrelétricos e nucleares, 1988, p.18.
} 
Somente em 1956, o presidente Juscelino Kubitschek criou a primeira estatal federal do setor elétrico, a Central Elétrica de Furnas S.A. e, em 1961, criou-se também a Eletrobrás Centrais Elétricas Brasileiras S.A. - empresa de economia mista, responsável pelo planejamento, financiamento e execução da política de energia elétrica no Brasil.

"Mudanças no cenário político, econômico e social brasileiro, guiadas pela força da ditadura militar para impor uma política de mercado internacional, colocaram o setor produtivo brasileiro numa linha de incentivo para culturas de exportação, de crédito e de preços mínimos, decisiva na utilização, pelos médios e grandes proprietários, de insumos e novas técnicas agrícolas. (...) Portanto, como parte da política imposta durante o governo militar, a modernização industrial atingiu tanto o espaço urbano quanto o rural. (...) Paviani remete a esse período dizendo que 'uma outra face dos esforços extrativos visando recordes na balança comercial (para o pagamento do serviço da dívida) se encontra no circuito industrial, que demanda cada vez maior suprimento de energia. Esta pressão do crescimento industrial ensejou a implantação de mega-usinas em vários pontos do território nacional". ${ }^{165}$

A partir de então, o Estado teve a sua participação aumentada paulatinamente no setor, chegando ao ponto do setor elétrico brasileiro estar formado por cerca de 60 empresas locais, estaduais ou regionais. Essa posição tem sido considerada por muitos como questionável, o que levou, acrescido da necessidade de gerar recursos, ao início da privatização do setor, sobretudo no que concerne à transmissão e distribuição de energia.

A atual crise do setor de geração de energia, refletindo-se diretamente na economia e na sociedade brasileira tem gerado uma tendência a buscarem-se novos investimentos e maximizar a produção e a oferta dentro de um prazo cada vez menor. Dentro desta perspectiva, investimentos em geração de energia, como no caso de Serra da Mesa tornam-se amplamente justificáveis do ponto de vista estatal, muito embora, as consequiências inevitáveis desse processo seja a intervenção, cada vez mais abrangente em diversos ecossistemas, cujos impactos nem sempre são passíveis de controle ou de previsão.

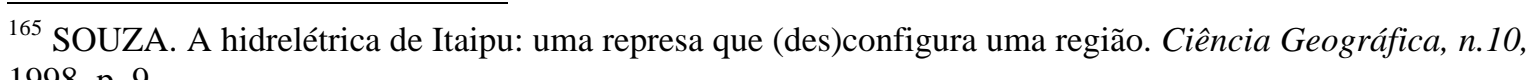
1998, p. 9. 
Devido a essas dificuldades, cria-se a necessidade de uma reflexão mais ampla com relação à busca de novas formas de produção energética que comprometam menos o meio ambiente. Segundo Branco ${ }^{166}$,

"se a construção de represas representa, de um lado, o progresso através da produção de energia elétrica, do abastecimento de água potável, da irrigação, da regularização da vazão dos rios, possibilitando o controle das enchentes, por outro lado, de modo contrário, traz como conseqüência uma série de alterações de caráter hidrológico ,com repercussões climáticas e ecológicas que, de modo geral, afetam profundamente a flora e a fauna tanto aquáticas como terrestres."

Outro fator a ser considerado é se os benefícios realmente atingem a população da região. $\mathrm{Na}$ maioria das vezes, as unidades produtoras de energia elétrica não oferecem um bom retorno à população regional, nem mesmo sob a forma de disponibilidade energética, visto que geralmente são unidades voltadas para atender à demanda do centro-sul do país e à demanda industrial.

$\mathrm{Na}$ realidade, os impactos sociais e ambientais de um grande empreendimento nunca estão totalmente sob controle das autoridades engajadas no processo. O fato é que a maioria desses impactos são de cunho irreversível, e, portanto, se não forem previstos com antecedência, muito pouco poderá ser feito após a conclusão das obras. Todos os grandes empreendimentos estão sujeitos a tais situações, e não apenas aqueles voltados para a construção de grandes hidrelétricas e suas respectivas barragens. Ocorre que, geralmente, os efeitos que a construção de uma barragem possam produzir sempre foram considerados como uma questão subordinada à questão principal, que é a questão energética.

De acordo com Sigaud; citado por Santos ${ }^{167}$,

"ao contrário do que poderia pensar, na construção de uma hidrelétrica não estão em jogo apenas os altos interesses nacionais de produção de energia para o desenvolvimento, mas também os interesses particulares de grupos de empresas que se beneficiam enormemente com os investimentos do setor elétrico,

\footnotetext{
${ }^{166}$ BRANCO \& ROCHA. Poluição, proteção e usos múltiplos de represas, 1983, p.1.

${ }^{167}$ SANTOS. Projetos hidrelétricos de grande porte e efeitos sociais: o exemplo do topocídio provocado pela barragem de Porto Primavera, 1998, p. 31.
} 
assim como os interesses do capital financeiro internacional, que fornece uma parcela importante dos recursos".

Assim, deve-se também considerar que, na decisão de se construir hidrelétricas, estão em jogo diversos tipos de interesses, sobretudo de grandes empresas consultoras encarregadas do planejamento do setor, de empresas da construção civil e aquelas que produzem equipamentos elétricos, dentre outras. Pode-se perceber portanto, que um empreendimento de tal porte não pode ser analisado de forma simplista, nem correr o risco de ser interditado apenas em função de interesses puramente ambientalistas.

Ainda de acordo com Santos, Op. Cit., uma outra questão que deve ser destacada é o fato de que, geralmente, a maioria dos EIA/RIMAs que são elaborados para os projetos de empreendimentos do setor elétrico são realizados por empresas consultoras contratadas pela própria empresa interessada na realização da obra. Dessa forma, a isenção e idoneidade das empresas contratadas podem ser colocadas em dúvida, visto que "dificilmente elas produzirão um RIMA propondo a não realização de um projeto, pois isso seria suicídio (...). Outro aspecto a ser considerado é o fato de que,

"além disso, muitas empresas de consultoria estão intimamente ligadas a empresas interessadas na aprovação dos grandes projetos. Nesse aspecto, Sigaud cita o exemplo do Consórcio Nacional de Engenheiros Consultores - CNEC, que é a empresa de consultoria responsável pelo estudo de viabilidade técnica da construção de usinas hidrelétricas no Xingu, sendo também responsável pela consultoria da Camargo Corrêa, provavelmente uma das maiores empresas de construção civil do país, que é uma das beneficiárias da energia subsidiada gerada por Tucuruí.

"Como resultado desta política de interesses, cujo objetivo final é a realização dos projetos, minimizando os imensuráveis impactos, percebe-se que a maioria dos estudos feitos por encomenda do setor elétrico são repetitivos, pobres, $e$ praticamente ignoram a dinâmica social e riqueza cultural existentes na área atingida." 168

A questão está de fato em ponderar-se a necessidade de produção de energia para atender a uma demanda crescente e a forma de se buscar a geração dessa mesma energia,

\footnotetext{
${ }^{168}$ SANTOS. Projetos hidrelétricos de grande porte e efeitos sociais: o exemplo do topocídio provocado pela barragem de Porto Primavera, 1998, p. 32.
} 
considerando-se aí todos os impactos sociais e ambientais que estão engajados no processo. No Brasil, as autoridades deixaram a situação chegar próximo ao insustentável: enquanto o consumo cresceu, passando de 276.000 gigawatt-hora em 1997 para 322.000 gigawatt-hora em 2001; o investimento caiu, passando de 6,2 US\$ bilhões em 1997 para 3,1 US\$ bilhões em 2001. Em contrapartida, os preços aumentaram sistematicamente, passando de 120 reais por megawatt-hora em 1997 para 172 reais por megawatt-hora em 2001, penalizando assim o consumidor final. A questão da oferta de energia no Brasil tem-se tornado um problema de grandes proporções, embora o Estado procure passar a impressão de que a situação está totalmente sob controle.

Outro problema a ser considerado sobre a energia elétrica é o fato de que ela é considerada por muitos como sendo a melhor forma de energia a se produzir no Brasil devido sobretudo ao grande potencial hidroenergético disponível no território nacional - e que a solução se resume simplesmente em aumentar os investimentos. Para Müller ${ }^{169}$,

"não há, ainda, formas conhecidas de gerar energia na quantidade exigida pelos atuais níveis de desenvolvimento, sem provocar efeitos socioambientais. Não obstante, a energia elétrica, uma vez gerada, é limpa, invisível, sem resíduos e contaminantes."

Este tipo de colocação é questionado por muitos autores e mesmo por diversos técnicos atualmente. Não é pelo fato de se tratar de uma energia limpa, após ter sido gerada, que se justificam grandes danos ao meio ambiente e também às comunidades envolvidas durante o processo de construção das unidades produtoras. Atualmente, a sociedade busca cada vez mais estar presente, de forma participativa nas decisões que envolvam grandes empreendimentos, visando a ser considerada quanto a seus anseios e necessidades .

De acordo com Santos ${ }^{170}$

"são milhares de pessoas que vêm seus interesses $e$ direitos, seus meios e modos de vida, além do seu próprio cotidiano afogados por um empreendimento que, na maioria das vezes, tem duvidosa transparência técnica e política. Porém,

\footnotetext{
${ }^{169}$ MÜLLER. Hidrelétricas, meio ambiente e desenvolvimento, 1995, p. 1.

${ }^{170}$ SANTOS. Projetos hidrelétricos de grande porte e efeitos sociais: o exemplo do topocídio provocado pela barragem de Porto Primavera, 1998, p. 32.
} 
poderia ser contra-argumentado que o que está em jogo é a geração de energia, insumo básico para o desenvolvimento econômico, tratando-se de uma alternativa nobre em relação à energia nuclear, já que não envolve graves riscos. Respondendo a este tipo de argumento se afirma que a questão não é essa, pois ninguém é contra, em princípio, a geração de hidreletricidade, Sigaud pondera: "para uma sociedade que pretende ser regida por princípios democráticos, torna-se imperativo que decisões deste tipo - que implicam em inversões maciças de capital e que trazem em seu bojo efeitos sociais tão graves - considerem, como uma variável tão importante quando a demanda de energia e os interesses de empresas sequiosas por encomendas milionárias ou energia barata, os interesses de alguns milhares de cidadãos brasileiros afetados por essas obras e a própria Nação brasileira."

Em muitos casos, a população local mobiliza-se para chamar a atenção quanto aos impactos mais contundentes a que está ou estará submetida com a concretização desses grandes empreendimentos. Na área da pesquisa, na região de Serra da Mesa, não se observou nenhum tipo de mobilização da população envolvida. Tal fato pode ser analisado a partir de, pelo menos dois fatores distintos:

1. A população da área de Serra da Mesa não apresenta, de modo geral, condições de questinonamento sobre o empreendimento devido à sua baixa escolaridade e pouco engajamento político verificado in loco. Embora $74 \%$ da população total tenha-se declarado como sabendo ler, e em contrapartida apenas $26 \%$ se declararam-se analfabetos, o índice de escolaridade medido, através do número de anos de estudo, é ainda muito baixo, conforme indica a figura 04.

2. O conhecimento que a população tinha sobre o empreendimento era a informação repassada pelos órgãos oficiais, envolvidos na concretização do projeto. FURNAS implantou o Programa de Comunicação Social na região com o objetivo de manter a população afetada direta ou indiretamente informada sobre as principais etapas de construção, bem como sobre os impactos gerados e as medidas e programas implementados. Obviamente que se trata da versão oficial da questão, mas que, de fato, não foi efetivamente questionada pela população da região de Serra da Mesa. O quadro 03 apresenta os principais tipos de informação fornecidas por FURNAS e o público alvo. 
Figura 04: Área de Inundação:

População de 5 anos ou mais - tempo de estudo

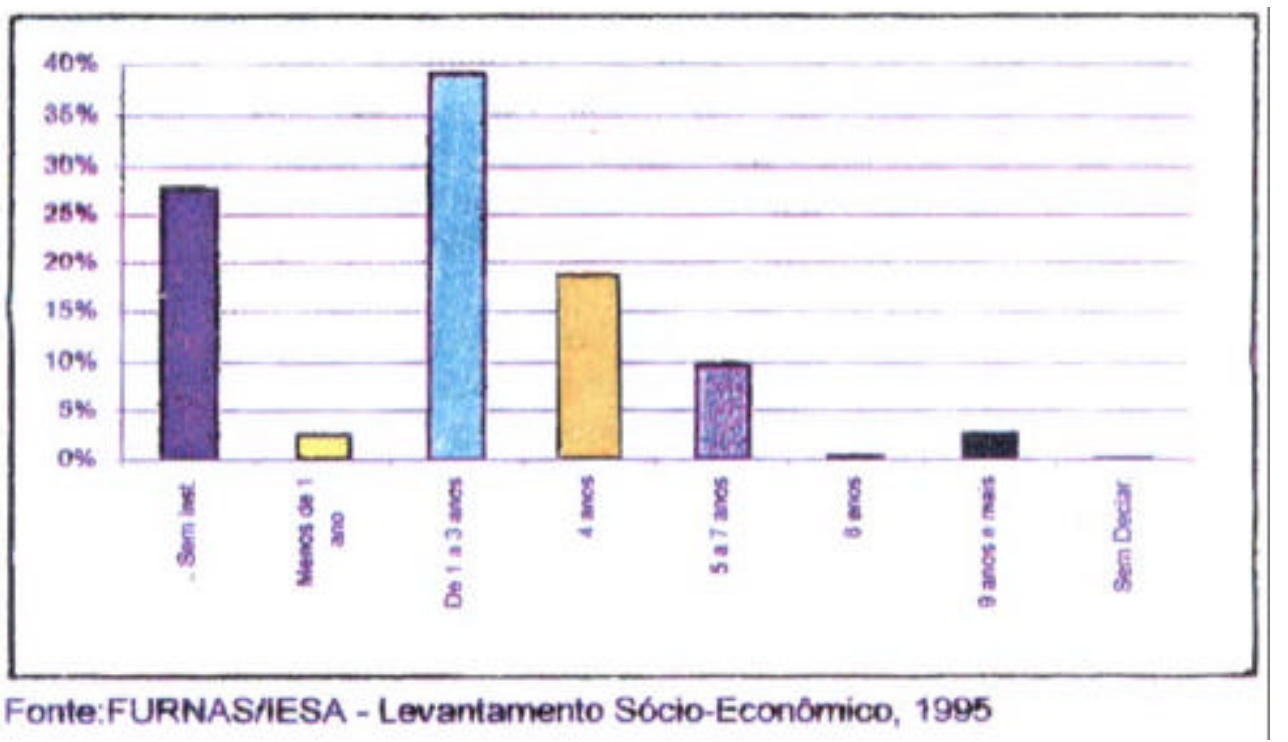


Quadro 03 - Ações de Comunicação Social para o Enchimento do Reservatório do AHE Serra da Mesa

\begin{tabular}{|c|c|c|}
\hline PÚBLICO ALVO & TIPO DE INFORMAÇÃO & $\begin{array}{c}\text { MEIO DE } \\
\text { COMUNICAÇÃO }\end{array}$ \\
\hline A Nível Nacional & $\begin{array}{l}\text { Localização do AHE, potência e } \\
\text { importância da operação do } \\
\text { empreendimento a nível regional e nacional }\end{array}$ & $\begin{array}{c}\text { Jornais de circulação } \\
\text { nacional e televisão }\end{array}$ \\
\hline $\begin{array}{c}\text { População dos } \\
\text { Municípios de } \\
\text { Minaçu, Uruaçu, } \\
\text { Niquelândia, Colinas } \\
\text { do Sul e Campinorte, } \\
\text { Prefeitura e Órgãos } \\
\text { Públicos, Lideranças } \\
\text { Locais e População } \\
\text { em Geral }\end{array}$ & $\begin{array}{l}\text { Principais etapas e ações do processo de } \\
\text { enchimento } \\
\text { Ações dos Programas de Fauna e Saúde } \\
\text { (riscos de doenças e eventuais acidentes } \\
\text { com animais peçonhentos) }\end{array}$ & $\begin{array}{c}\text { Folder } \\
\text { Cartaz anunciando a } \\
\text { data de fechamento } \\
\text { Cartaz, Folder e } \\
\text { Palestras }\end{array}$ \\
\hline $\begin{array}{l}\text { População } \\
\text { Residente } \\
\text { na AID }\end{array}$ & 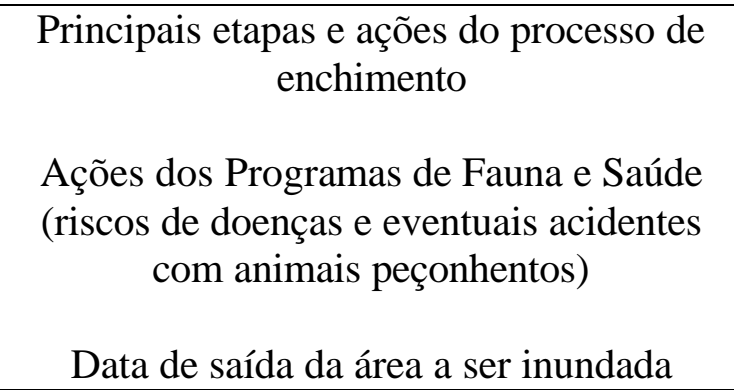 & $\begin{array}{c}\text { Folder } \\
\text { Cartaz anunciando a } \\
\text { data de fechamento } \\
\text { Palestras } \\
\text { Jornais de circulação } \\
\text { local, rádio e } \\
\text { comunicação por } \\
\text { carta }\end{array}$ \\
\hline $\begin{array}{l}\text { População a Jusante } \\
\text { até o Rio Preto }\end{array}$ & $\begin{array}{l}\text { Ações de enchimento } \\
\text { Efeitos ambientais a jusante a partir do } \\
\text { fechamento }\end{array}$ & $\begin{array}{l}\text { Folders entregues em } \\
\text { cada propriedade, } \\
\text { com explicação oral } \\
\text { adicional } \\
\text { Rádio } \\
\end{array}$ \\
\hline $\begin{array}{l}\text { São Salvador do } \\
\text { Tocantins e Retiro }\end{array}$ & $\begin{array}{l}\text { Importância do AHE Serra da Mesa } \\
\text { Efeitos ambientais a jusante a partir do } \\
\text { fechamento }\end{array}$ & $\begin{array}{c}\text { Folders } \\
\text { Cartazes } \\
\text { Rádio }\end{array}$ \\
\hline $\begin{array}{c}\text { Propriedades a } \\
\text { Jusante até a Foz do } \\
\text { Rio Paraná }\end{array}$ & $\begin{array}{l}\text { Importância do AHE Serra da Mesa } \\
\text { Efeitos ambientais a jusante a partir do } \\
\text { fechamento }\end{array}$ & $\begin{array}{l}\text { Folder } \\
\text { Cartazes } \\
\text { Rádio } \\
\end{array}$ \\
\hline
\end{tabular}

Fonte: FURNAS - Projeto Básico Ambiental do Aproveitamento Hidrelétrico Serra da Mesa - Agosto/96.

Em áreas mais desenvolvidas economicamente, onde a população se apresenta com maior poder de mobilização política, a participação desse segmento nos rumos do projeto é bastante significativa. Rosa ${ }^{171}$ analisou a situação da barragem de Machadinho, na

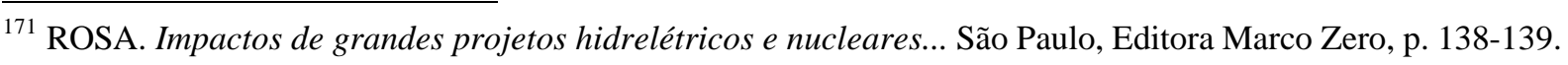


confluência dos rios Pelotas e Apuauê, entre os estados do Rio Grande do Sul (município de Marcelino Ramos) e Santa Catarina (município de Piratuba), construída pela Centrais Elétricas Sul do Brasil S. A. - ELETROSUL, concessionária da ELETROBRAS. De acordo com o projeto original, a hidrelétrica de Machadinho seria a primeira de uma série de barragens a serem implantadas na bacia do rio Uruguai. Ocorre que a população local se mobilizou em inúmeras manifestações de diferentes facções da sociedade local, questionando sobretudo a questão da desapropriação das terras e suas respectivas indenizações, em estudos desde o ano de 1979. Em 1982

"a imprensa de Porto Alegre, referindo-se à resposta da ELETROSUL à COTREL - Cooperativa Tritícula de Erexim Ltda - observa que a manifestação das lideranças e dos próprios agricultores a serem atingidos pelas barragens parece já estar provocando nos responsáveis pelas obras a consciência de pensarem de modo diferente de como vinha acontecendo e e de como já ocorreu, com as demais barragens projetadas $e$ idealizadas. (...) Em início de maio (de 1982), a ELETROSUL desapropria 15 propriedades (colônias) para a formação do canteiro de obras. (...) Como saldo positivo dessa primeira luta, verificou-se a união dos atingidos não fazendo acordo individualmente. Eles se organizaram, estudaram as propostas em conjunto, reivindicaram e conseguiram comprar outra terra e continuam na agricultura." 172

Em Goiás, na área de estudo, tal mobilização não chegou a ocorrer. Durante os trabalhos de campo realizados na área, verificou-se a insatisfação de grande número de proprietários com os valores pagos a título de indenização pelas terras desapropriadas, sobretudo quando em uma área muito próxima os valores eram muito diferentes, resultados do poder de negociação individual de cada proprietário. Desta forma, pode-se inferir que, se tivesse ocorrido uma mobilização dessas pessoas em torno de um fim comum, elas poderiam ter sido mais bem atendidas em suas expectativas, pelo menos quanto ao valor recebido, já que, de maneira geral, as terras desapropriadas constituíam a melhor área agricultável de cada propriedade, ou seja, as terras localizadas nos vales e nos terraços dos cursos d'água. O que não foi inundado são geralmente as áreas mais elevadas, onde, comumente, a qualidade da terra é pior, muitas vezes apresentando diversos afloramentos rochosos. Em muitos casos, as partes não inundáveis constituíram pequenas ilhas, sem possibilidade de ocupação futura. 
De qualquer forma, o que se observa é que um empreendimento da magnitude de uma Usina Hidrelétrica, ao ser implantada, implica interferências não apenas na paisagem, mas também nas relações sociais e econômicas que geralmente podem ser consideradas como impactantes, devido ao grau de mudanças que oferecem. Devido a diversos fatores, entre eles a própria dificuldade de mensuração e o desinteresse das autoridades responsáveis, os impactos sociais são considerados em menor escala do que os impactos ambientais. Diversos autores têm analisado os impactos ambientais causados por usinas hidrelétricas, mas os sociais e econômicos são restritos a um pequeno grupo de pesquisadores, sobretudo geógrafos voltados para esta questão ${ }^{173}$.

Santos $^{174}$, citando Branco, coloca que

"na língua portuguesa, impacto tem o significado de colisão, choque, podendo portanto definir uma espécie de trauma resultante de uma ação ou obra humana em desarmonia com as características e o equilíbrio do meio ambiente. Esses impactos desencadeados pela ação humana são bem diferentes dos impactos chamados naturais, como por exemplo, raios que caem em florestas e provocam incêndios (...) Os impactos antrópicos caracterizam-se, principalmente, por quebrarem um ciclo natural, uma ordem existente entre os sistemas que são interdependentes e inter-relacionados, garantindo o fluxo contínuo de energia. Há entre os sistemas uma intensa harmonia, mas ao mesmo tempo ele é muito frágil e dinâmico, possuindo uma capacidade quase infinita de auto-regulação $e$ adaptação às novas condições naturais do ambiente. Porém, a interferência do homem de uma forma contínua e muitas vezes desordenada acaba provocando danos irreparáveis.

Esta é a situação que comumente ocorre em interferência de grande porte como a construção de uma grande unidade produtora de energia elétrica. No caso de Serra da Mesa, diversos sistemas naturais, que estavam em equilíbrio, sofreram alterações, sem se considerarem profundamente as conseqüências que adviriam desse processo. Um exemplo claro são as áreas que apresentavam relevo cárstico, que, como se sabe, é um tipo de

\footnotetext{
${ }^{172}$ ROSA. Impactos de grandes projetos hidrelétricos e nucleares: aspectos econômicos e tecnológicos, sociais $e$ ambientais, 1988, p. 139.

${ }^{173}$ Sobre o tema ver: SANTOS. Projetos hidrelétricos de grande porte ...Op. Cit., VILLELA. Nova Ponte, MG: uma paisagem a ser vivida, Op. Cit.; SILVA. Rio Manso: a vivência do impacto de um grande projeto, Op. Cit., entre outros.
} 
ecossistema frágil e cuja dinâmica é preciso conhecer-se bem. Estas áreas foram inundadas sem um estudo mais amplo, sendo que em alguns casos tratava-se de áreas pouco conhecidas e pouco exploradas, constituídas por regiões praticamente intocadas.

Alterações geológicas são uma conseqüência comum em áreas de represamento de rios, quando se atingem grandes extensões, levando geralmente a se registrarem pequenos abalos sísmicos. De acordo com Branco ${ }^{175}$,

"em várias partes do mundo a formação de grandes reservatórios artificiais causo terremotos de intensidades leves e médias, em regiões consideradas livres de atividades sísmicas. Os abalos sísmicos se restringiram à zona imediata da implantação da barragem e do reservatório, (...), e os abalos foram causados pela adaptação das formações geológicas da área do reservatório às pressões hidrostáticas elevadas e às condições provocadas pela infiltração d'água."

Acredita-se que tais condições, em áreas de relevo calcário possam ser maximizadas, sem, no entanto, ter-se conhecimento total do fenômeno e de suas consequiências. FURNAS implantou o Programa de Monitoramento Sismológico na área de Serra da Mesa, no entanto, como o próprio nome indica, trata-se de um monitoramento, para proceder-se a um controle dos possíveis abalos sísmicos que a região venha a sofrer. Como forma preventiva nada pode ser feito.

Segundo Branco ${ }^{176}$, diversos outros tipos de impactos ambientais podem ocorrer em áreas em que se implantam projetos hidrelétricos tais como:

1. Alterações hidrológicas: causada geralmente a partir da

"interrupção permanente do ritmo natural e da vazão de um curso d'água, transformando locais de correnteza em ambientes lênticos. (...) As alterações hidrológicas podem estar relacionadas às modificações de temperatura da água e à velocidade de assoreamento. Assim é que a diminuição da corrente facilita a sedimentação, tanto do material autóctone como do alotóctone, formando bancos de lodo, onde, além da matéria orgânica, podem ser acumulados sais minerais nutrientes necessários aos vegetais aquáticos.

\footnotetext{
${ }^{174}$ SANTOS. Projetos hidrelétricos de grande porte e efeitos sociais: o exemplo do topocídio provocado pela barragem de Porto Primavera, 1998, p. 33.

${ }^{175}$ BRANCO. Poluição, proteção e usos múltiplos de represas, 1983, p. 3.
} 
2. Alterações no clima: de acordo com análise feitas em outras áreas onde ocorreu represamento de rios,

"a represa pode exercer efeitos antagônicos sobre o clima, ou, mais especificamente, sobre a umidade relativa do ar. Em zonas de densa cobertura vegetal, (...) a superfície livre de evaporação do lago é forçosamente menor que a soma das superfícies das folhas através das quais se dá a transpiração vegetal, havendo conseqüentemente, decréscimo da umidade relativa.

3. Influências nas características físicas e químicas da água: outro fator a ser considerado é a questão da interdependência entre os elementos da natureza. Uma área que vier a sofrer uma série de alterações geológicas e climáticas, dificilmente deixará de apresentar alterações nas características de sua água. Assim, como conseqüência direta do desmatamento e do assoreamento,

"as partículas de sedimento que chegam à água provocam um aumento no índice de cor e de torbidez, que, diminuindo a transparência, dificultam ou impedem a penetração da luz necessária às reações de fotossíntese do plâncton. (...) Esse fenômeno torna-se um fator de seleção para os seres aquáticos.

4. Efeito sobre a paisagem: este é talvez o mais visível dos efeitos.

"Os lagos artificiais dão uma imagem nova e diferente à paisagem. Mesmo quando o desmatamento é feito com cuidado, no local abrangido pela faixa de oscilação do nível do reservatório, sempre permanece o aspecto de natureza morta. Às vezes, as novas margens se tornam pantanosas, podendo se constituir em focos de vetores de doenças endêmicas. (...) Aliado à presença da represa e da nova paisagem criada, em certas regiões, é implantado o turismo. (...) transformando-se em locais de recreação. Surgem clubes náuticos, que se estabelecem em suas margens, bem como casas de veraneio. Às vezes, criam-se animais aquáticos e semi-aquáticos, e pratica-se a pesca recreativa.",177

Esse é um importante fator a ser considerado para a área de estudo. Uma das maiores expectativas da população local é que a economia local possa reabilitar-se através das

\footnotetext{
${ }^{176}$ BRANCO. Poluição, proteção e usos múltiplos de represas, 1983, p. 2-4.

${ }^{177}$ BRANCO. Poluição, proteção e usos múltiplos de represas, 1983, p. 4.
} 
atividades turísticas que se espera sejam implantadas na região. Como a economia local é debilitada, o turismo surge como sendo o caminho natural para a sua reabilitação, muito embora não se esteja considerando que se trata de uma área sem nenhuma tradição no ramo, além do fato de que está muito distante dos principais centros urbanos regionais.

Há que se considerar que o turismo pode ser também uma atividade impactante para o meio ambiente. Caso não seja desenvolvido um programa cuidadoso de proteção e respeito à natureza, com investimentos maciços, sobretudo em educação, o que poderia ser um benefício pode vir a tornar-se um problema de grandes proporções.

No entanto, sobre o assunto, Rosa ${ }^{178}$ faz importantes colocações, considerando que o conceito de impacto ambiental tem acepções diferenciadas, em se tratando de países desenvolvidos ou subdesenvolvidos. De acordo com o autor, o enfoque dado aos problemas ambientais, nos países desenvolvidos, é sobretudo de caráter tecnológico, enquanto que nos países subdesenvolvidos ou nos que se intitulam em desenvolvimento, o conceito é muito mais amplo, posto que abrangem questões sócio-econômicas e políticas.

\begin{abstract}
“Assim, existem problemas ambientais característicos do subdesenvolvimento, típicos do superdesenvolvimento e também do desenvolvimento desequilibrado, não sendo necessário que as variáveis e os processos ambientais relacionados com esses problemas sejam os mesmos. Inclusive, quando diferentes grupos humanos vivenciam os mesmos problemas ambientais, a importância relativa que são atribuídas às distintas variáveis ambientais diferem de um grupo para outro. Portanto, muitas das diferenças da atitude dos países desenvolvidos e em desenvolvimento em relação aos ambientes globais e locais podem ser atribuídas a diferenças em vários fatores. Entre eles não apenas diferem os meios ambientais operativos reais, como também diferem os componentes percebidos, deduzidos $e$ valorizados. ${ }^{179}$ Estas diferenças atuam como foco de variação, de tal modo que mesmo que os ambientes operativos sejam essencialmente os mesmos, sempre surgem grandes divergências em relação às políticas a serem adotadas.”
\end{abstract}

\footnotetext{
${ }^{178}$ ROSA. Impactos de grandes projetos hidrelétricos e nucleares: aspectos econômicos e tecnológicos, sociais e ambientais. 1988, p. 180.

${ }^{179}$ Grifo nosso.
} 
Sobre o tema, pode-se inferir, portanto, que não são apenas os problemas ambientais que se diferenciam, mas sobretudo as atitudes adotadas em relação a eles. Neste caso, o termo atitude reporta-se não apenas a medidas adotadas pelas autoridades competentes - o que inegavelmente é de fundamental importância para se definirem comportamentos - mas também à busca de uma consciência ambiental, em sentido mais amplo, abrangendo a comunidade como um todo. Quando um país alcança esta condição, a própria sociedade passa a monitorar a questão ambiental, engajando-se no propósito de criar condições melhores para si mesma e para as gerações que virão.

Um caminho a se seguir é a necessidade - e obrigatoriedade, garantida por uma legislação rígida - de se avaliar, de forma abrangente, irrestrita e isenta, os riscos que um empreendimento de grandes proporções possa gerar em termos de impacto ambiental. Mas a avaliação de riscos em países subdesenvolvidos ainda é uma tarefa pouco consolidada, mesmo em projetos em que se exige a apresentação do AIA (Avaliação de Impacto Ambiental). Não é incomum constatar que grande parte destes relatórios constituem-se em documentos de grande vulnerabilidade quanto à metodologia, pouco fundamentados e de uso excessivamente tecnocrata.

Há que se considerar também a importância da opinião pública ao se avaliar a importância de um novo empreendimento. Uma unidade produtora de energia elétrica é e será sempre um sistema antrópico, altamente impactante, e como tal precisa ser considerado pelas autoridades e pela comunidade envolvida no processo. Ainda de acordo com Rosa ${ }^{180}$,

"para que se melhore o meio ambiente humano em situações diferentes, mais além das possíveis semelhanças ou diferenças dos ambientes objetivos, talvez seja conveniente que as politicas $e$ as ações a serem implementadas sejam distintas. (...)

"Apesar da inegável evolução verificada no tratamento das questões ambientais associadas à implantação e à operação de usinas hidrelétricas no Brasil nos últimos anos, observa-se ainda que os governos locais e a sociedade continuam não tendo qualquer interferência nos processos de tomada de decisão. (...) O processo de tomada de decisão deve ser

\footnotetext{
${ }^{180}$ ROSA. Impactos de grandes projetos hidrelétricos e nucleares: aspectos econômicos e tecnológicos, sociais e ambientais, 1988, p.181.
} 
democrático (e não autoritário) e técnico ao mesmo tempo. Deve-se ter em mente que, para o Brasil, a questão essencial é o gerenciamento de conflito, de maneira a tornar possível a resolução de problemas.”

Assim, pode-se inferir que a questão dos riscos e dos impactos ambientais em um país como o Brasil, com suas peculiaridades e especificidades, assume também características únicas. Faz-se necessário conciliar aspectos típicos de um país industrializado e urbano (como a necessidade de aumentar a oferta de energia de acordo com o aumento da demanda) com características próprias do subdesenvolvimento (como por exemplo, a urgência da crise energética, típica da imprevidência de autoridades pouco comprometidas com a nação), e também aspectos técnicos referentes ao processo produtivo em si; aspectos políticos (em que nem sempre as decisões estão voltadas ao interesse do país e da sociedade) e aspectos sociais, dos quais a sociedade brasileira busca participar mais ativamente dos problemas que a ela atingem diretamente. Percebe-se, portanto, que a questão assume feições realmente complexas. Some-se a isso o fato de que um empreendimento desse porte passa a alterar as relações sociais e culturais na comunidade em que se insere, quando até mesmo o patrimônio cultural passa a sofrer intervenção e é colocado em risco.

\section{O Patrimônio cultural (resgatado ou perdido?) de Serra da Mesa}

Como já foi dito anteriormente, para dar continuidade às obras de Serra da Mesa, fezse necessário implementar uma série de programas ambientais que FURNAS justificou como sendo importantes, visto que, para a empresa "o meio ambiente é uma componente fundamental no desenvolvimento de suas atividades."181 Dentre esses programas, está inserido o Projeto de Salvamento Histórico-Arqueológico, desenvolvido por uma equipe de pesquisadores da UFMG e tratado mais detalhadamente nesta pesquisa.

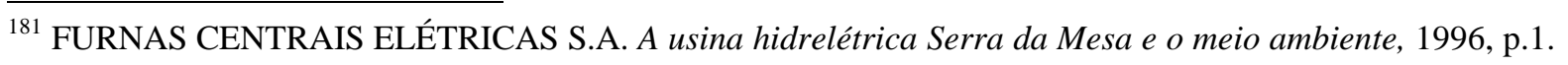


Para proceder-se ao salvamento do que viria a se constituir em patrimônio históricoarqueológico da região, fazia-se necessário primeiramente conhecer esse material. Para tanto, o caminho mais seguro seria reportar à bibliografia existente referente ao tema, o que de fato não se caracteriza como sendo muito extensa, uma vez que existem alguns estudos sobre o período colonial em Goiás como um todo, mas, sobre a área do empreendimento, a bibliografia é realmente exígua. "São poucos os documentos e pouquíssimas as crônicas que se referem ao descobrimento e o povoamento de Goiás." 182

Dessa forma, partiu-se do pressuposto de que o que poderia ser encontrado na região de Serra da Mesa não seria muito divergente do que se conhece para o restante do estado, sobretudo levando-se em consideração que se tratava de uma área mineradora, fato que incentivou a ocupação e o surgimento de várias cidades. A partir de então, procedeu-se a exaustivo trabalho de prospecção, em que os pesquisadores foram orientados para registrar todos os vestígios antigos, e só depois, então, seria feita uma triagem para confirmar ou descartar tais vestígios como sendo ou não dignos de estudo.

Para FURNAS, tornava-se fundamental conhecer e resgatar tal patrimônio, uma vez que se conhecia muito pouco sobre a ocupação histórica da região. Exatamente devido a esse pouco conhecimento mais se fazia importante o projeto de salvamento desses bens. Um empreendimento hidrelétrico compromete definitivamente os bens culturais - históricos ou pré-históricos - que porventura existam na área onde se instala a represa da unidade produtora de energia. Como correr o risco de se perder para sempre um patrimônio ainda desconhecido? Tal perspectiva tornou necessária a execução do projeto de salvamento.

De acordo com Guimarães ${ }^{183}$, coordenador do Projeto de Salvamento HistóricoArqueológico de Serra da Mesa,

"em arqueologia a incerteza do achado está associada à sua possibilidade. Um projeto desta natureza (arqueológica histórica) permite o cruzamento de diferentes tipos de informações, o que certamente pode reduzir sua margem de incerteza, que mesmo assim, ainda permanece grande. No caso, estamos tratando a articulação entre incerteza e probabilidade,

\footnotetext{
${ }^{182}$ MAGALHÃES. Expansão geográfica do Brasil colonial, 1978, p. 179.

${ }^{183}$ UNIVERSIDADE FEDERAL DE MINAS GERAIS. Salvamento histórico-arqueológico na área atingida pela represa da Usina de Serra da Mesa-Goiás, vol.1, 1998, p.9.
} 
que deve ser entendida dentro das especificidades da arqueologia histórica. A grande questão não é a dúvida entre encontrar ou não os vestígios procurados e sim, onde estão, qual a sua dimensão e o significado provável."

A Usina Hidrelétrica de Serra da Mesa era um projeto definitivo, com um cronograma de execução pronto e em andamento, o que definia como prioritário o início do programa de salvamento, através dos trabalhos de prospecção. A grande dimensão da área em questão (aproximadamente $1780 \mathrm{~km}^{2}$ ), levou à necessidade de se trabalhar em sub-áreas, cujos limites foram definidos levando-se em consideração as bacias dos mais importantes afluentes do rio Tocantins, que é o curso d'água principal, em que se instalou a UHE.

Dessa forma, durante os meses de maio a novembro de 1995 buscou-se localizar o maior número possível de vestígios que pudessem vir a se constituir em sítios arqueológicos.

“A partir da localização de cada sítio, foram realizadas as tarefas básicas exigidas como a definição/delimitação da área de ocorrência dos vestígios, a identificação do tipo de sítio, a localização precisa na planta da área e a descrição do conjunto de evidências, seguida de levantamento fotográfico." 184

Além da dimensão da área a ser pesquisada, outra dificuldade que se constatou in loco, refere-se à imprecisão das cartas topográficas existentes. Embora sejam mapas oficiais, elaborados pelo Ministério do Exército para toda a região Centro-Oeste, no período de 1974 a 1976, constatou-se, na prática, que estes documentos apresentavam diversas irregularidades, tais como incoerências toponímicas, supressão de dados e discordância entre a malha viária mapeada e a real, sobretudo quanto ao grande número de novas estradas vicinais que foram implantadas, desde o momento de elaboração desses mapas até o momento atual. Obviamente que deslocar-se em uma área não-urbana, desconhecida e sem se poder confiar plenamente nos mapas de que se dispõe não é uma tarefa fácil.

Outra dificuldade, de ordem prática, residia na exigência de se determinar se os sítios prospectados estavam dentro ou fora da área de inundação. O limite que se fazia necessário observar era a cota de $460 \mathrm{~m}$ de altitude, referente à cota de inundação da represa. No entanto,

\footnotetext{
${ }^{184}$ UNIVERSIDADE FEDERAL DE MINAS GERAIS. Salvamento histórico-arqueológico na área atingida pela represa da Usina de Serra da Mesa - Goiás, vol. 1, 1998, p. 10.
} 
as cartas topográficas disponíveis para a região apresentavam-se cotadas de 50 em $50 \mathrm{~m}$, e em escala 1:100.000, não sendo considerada o ideal para o grau de precisão que se fazia necessário em campo. A alternativa mais viável foi o uso de equipamentos de GPS (Sistema de localização geográfica via satélite), que a partir de um determinado ponto, possibilita precisar-lhe a posição, através de coordenadas geográficas, fornecendo também a altimetria do mesmo. Constatou-se na prática que, embora a localização se constituísse em um dado extremamente confiável, o mesmo não se dava com a altimetria, sobretudo porque os equipamentos importados eram extremamente sensíveis às variações de temperatura. Durante o decorrer do dia, quando as temperaturas tornavam-se mais elevadas, estes equipamentos iam-se desrregulando, tornando impraticável a coleta desse tipo de dado.

Ocorre que essa informação era absolutamente essencial, uma vez que seria ela que iria definir a necessidade de proceder-se ao salvamento ou não de um determinado sítio. A coordenação do Projeto de Salvamento optou então por considerar todos os sítios onde havia dúvida quanto à sua localização precisa (se dentro ou fora da área de inundação), além de referendar

"a necessidade de avaliação e monitoramento futuro dos sítios localizados na área de influência indireta da represa. (...) Os trabalhos de prospecção (...) reuniram um total de 210 ocorrências de vestígios arqueológicos. $O$ trabalho de salvamento mostrou que muitos destes vestígios faziam parte de um mesmo contexto, daí várias destas ocorrências terem sido aglutinadas, consolidando o número de sítios em 177. (...) $O$ resultado foi um universo de 177 sítios prospectados, dos quais 106 estão dentro da área inundável e 51 na sua periferia." 185

A importância de se proceder ao salvamento deste material encontrado na região de Serra da Mesa ficou constatada no fato de que, uma área tão afastada dos centros financeiros e industriais do país, apresentasse grande riqueza de vestígios, corroborando a diversidade cultural já inferida pela pesquisa bibliográfica.

"No que diz respeito à estratégia adotada poder-se-ia objetar que necessariamente haveria redundância na obtenção de dados já que o pretendido era a cobertura da maior parte

\footnotetext{
${ }^{185}$ UNIVERSIDADE FEDERAL DE MINAS GERAIS. Salvamento histórico-arqueológico na área atingida pela represa da Usina de Serra da Mesa - Goiás, vol. 1, 1998, p.10.
} 
possível da área. Tal objeção foi refutada largamente pelos resultados atingidos.

"Se por um lado há um conjunto de informações que se repetem, por outro lado o universo das diferenças é extremamente rico para justificar a estratégia adotada. $O$ argumento que pretende justificar a eliminação das diferenças com base na existência de semelhanças ignora que a realidade é dialética e que o todo é constituído por ambas (semelhanças $e$ diferenças). Privilegiar um dos aspectos em detrimento do outro é construir uma visão distorcida da realidade histórica pesquisada."

Certamente que não se pretende acreditar que o universo pesquisado tenha esgotado completamente todas as manifestações, em termos de cultura material para a área de Serra da Mesa. Nenhuma pesquisa arqueológica pode ter tal pretensão. No entanto, tudo o que foi constatado como sendo vestígio do período de ocupação histórica da região foi considerado como sendo um sítio em potencial. O trabalho de resgate desse material tornou-se então prioritário. Para FURNAS, esse empreendimento visava a compensar o impacto causado pela construção da represa, por isso tornara-se tão urgente a sua execução.

De qualquer forma, a Usina Hidrelétrica de Serra da Mesa viria a ser o instrumento através do qual seria possibilitado à comunidade acadêmica e à sociedade brasileira, em geral, conhecer um pouco mais da história de Goiás e de sua ocupação, no período colonial. Através dos sítios arqueológicos encontrados, um pouco dessa história pôde ser contada.

"Segundo Pedro Paulo Abreu Funari, não obstante a memória histórica brasileira tenha sido estudada a partir de diversos pontos de vista, raramente os estudiosos se preocuparam com a relação entre a cultura material, a arqueologia e a formação de uma memória histórica. (...) Nessa medida, a preservação da memória da região (...) atingida pela Usina de Serra da Mesa, através do salvamento dos vestígios materiais e a reconstituição de sua trajetória histórica, elegendo esses vestígios como elementos decisivos na pesquisa, reveste-se de especial importância." $" 187$

\footnotetext{
${ }^{186}$ UNIVERSIDADE FEDERAL DE MINAS GERAIS. Salvamento histórico-arqueológico na área atingida pela represa da Usina de Serra da Mesa - Goiás, vol. 1, 1998, p.11.

${ }^{187}$ UNIVERSIDADE FEDERAL DE MINAS GERAIS. Salvamento histórico-arqueológico na área atingida pela represa da Usina de Serra da Mesa - Goiás, vol. 1, 1998, p. 31.
} 
Para facilitar o trabalho de análise posterior, os sítios pesquisados foram agrupados de acordo com as seguintes categorias (em função dos vestígios predominantes): fazendas, unidades de mineração, sítios mistos (quando apresentavam evidências de atividades agropastoris e de mineração), cemitérios, presídios, diversos (quando não apresentavam vestígios suficientes para definir a sua função) e núcleos urbanos.

Para que seja possível compreender a riqueza do material encontrado em Serra da Mesa, faz-se necessário uma caracterização de cada uma das categorias acima definidas:

\subsection{Fazendas}

"Sob a denominação genérica de fazenda entende-se o conjunto formado pela propriedade territorial, juntamente com os elementos que possibilitam a permanência humana e o desenvolvimento das atividades econômicas, para as quais a unidade produtiva está voltada." 188 Toda evidência de moradia que não estivesse em um contexto urbano (na região, contexto urbano se limita a aldeias e arraiais), foi considerada como sendo fazenda.

Os vestígios encontrados nesta categoria resumiam-se a fragmentos - geralmente muito degradados - de habitações e de outros elementos construtivos, típicos de unidades produtoras rurais, tais como currais (de pedras ou de madeira), monjolos, moinhos, pocilgas e canais para abastecimento de água.

Os sítios desta categoria vieram confirmar as expectativas levantadas pela bibliografia sobre o tema. Não foram encontradas evidências de construções grandes nem luxuosas, fato que ainda pode ser observado nos dias atuais. Mesmo as grandes fazendas da região caracterizam-se pela sobriedade das construções, em geral de tamanho acanhado e modestas, com pequena variedade de material construtivo, predominando aí o uso dos blocos rochosos (elemento comum em toda a arquitetura barroca colonial). Devido à raridade com que foram encontrados vestígios, pode-se inferir por exemplo que a cobertura de telhas era um elemento construtivo bastante raro na região. Para toda a área abrangida pela pesquisa (cerca de 1780

\footnotetext{
${ }^{188}$ UNIVERSIDADE FEDERAL DE MINAS GERAIS. Salvamento histórico-arqueológico na área atingida pela represa da Usina de Serra da Mesa - Goiás, vol. 1, 1998, p.12.
} 
$\mathrm{km}^{2}$ ), foram encontrados apenas dois sítios com indícios concretos da fabricação de telhas. Assim, quanto mais distantes dessas áreas, mais raros eram os vestígios de sua utilização. Ainda hoje é comum o uso de palhas e folhas de palmeiras diversas para a cobertura das casas da região, sobretudo na zona rural e nas periferias mais pobres das cidades.

Também nos acessórios e no mobiliário, a exigüidade é muito comum, tanto nos vestígios históricos quanto na atualidade. Oscar Leal ${ }^{189}$ descreve a rusticidade dos sítios rurais daquela época:

"A casa ou choupana é construída ao rez do chão, no qual estão fincados cinco ou sete esteios, que sustentam uma parede de varas e rachas de taquara, seguras umas às outras por cipós, mal barrada e que o tempo tem-se incumbido de desmoronar. O tecto (...) era de palha de burity. Portas não existem também, o que alli há são apenas algumas varas ou páos brutos que ligados quando o morador quer, servem de tapagem e como se vê a coisa mais simples que se encontra em habitação humana. Louça, mobília, e outros trastes são cousas de luxo como essa gente ignorante diz e não aparecem. Há em vez de cama ou de rede - o girao, outra geringonça feita de varas sobre forquilhas cravadas no chão; em vez de bancos troncos de árvores ou pesadas pedras. Um pericarpo ou uma cuia substitui a bacia, o bulle, a chícara, o prato, a farinheira, conforme o tamanho."

Assim, não causa estranheza também a escassez de variedade dos vestígios de cultura material encontrados para os sítios arqueológicos do tipo fazendas na região de Serra da Mesa. Objetos de uso cotidiano são praticamente inexistentes, sendo que a maioria desses vestígios estão catalogados como fragmentos de construções e de equipamentos: alicerces, currais, monjolos, engenhos, fornalhas e fornos de pedra, constituindo-se assim o universo rural do interior de Goiás, no período histórico. (Ver fotos 06 a 10) "Como foi dito, os vestígios das residências não indicam hábitos excepcionais, mas apenas o cotidiano de uma vida simples, para não dizer austera." 190

\footnotetext{
${ }^{189}$ LEAL. Viagem às terras goianas (Brazil Central), 1980, p.67.

${ }^{190}$ UNIVERSIDADE FEDERAL DE MINAS GERAIS. Salvamento histórico arqueológico na área atingida pela represa de Serra da Mesa - Goiás, vol. 1, 1998, p. 13.
} 


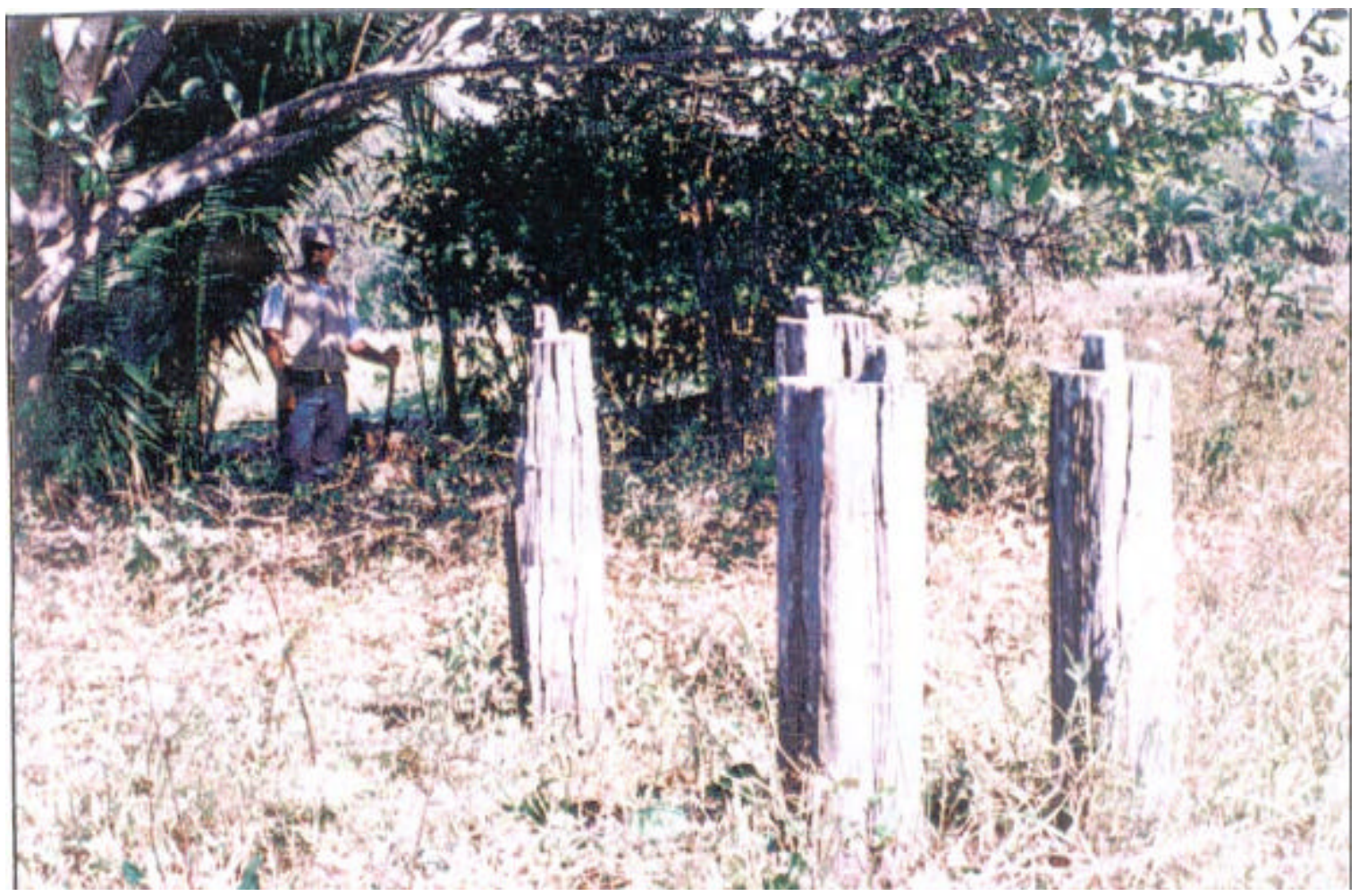

Foto 06: Vestígios de engenho

(Foto: UFMG/Projeto de salvamento histórico-arqueológico na área da represa de Serra da Mesa)

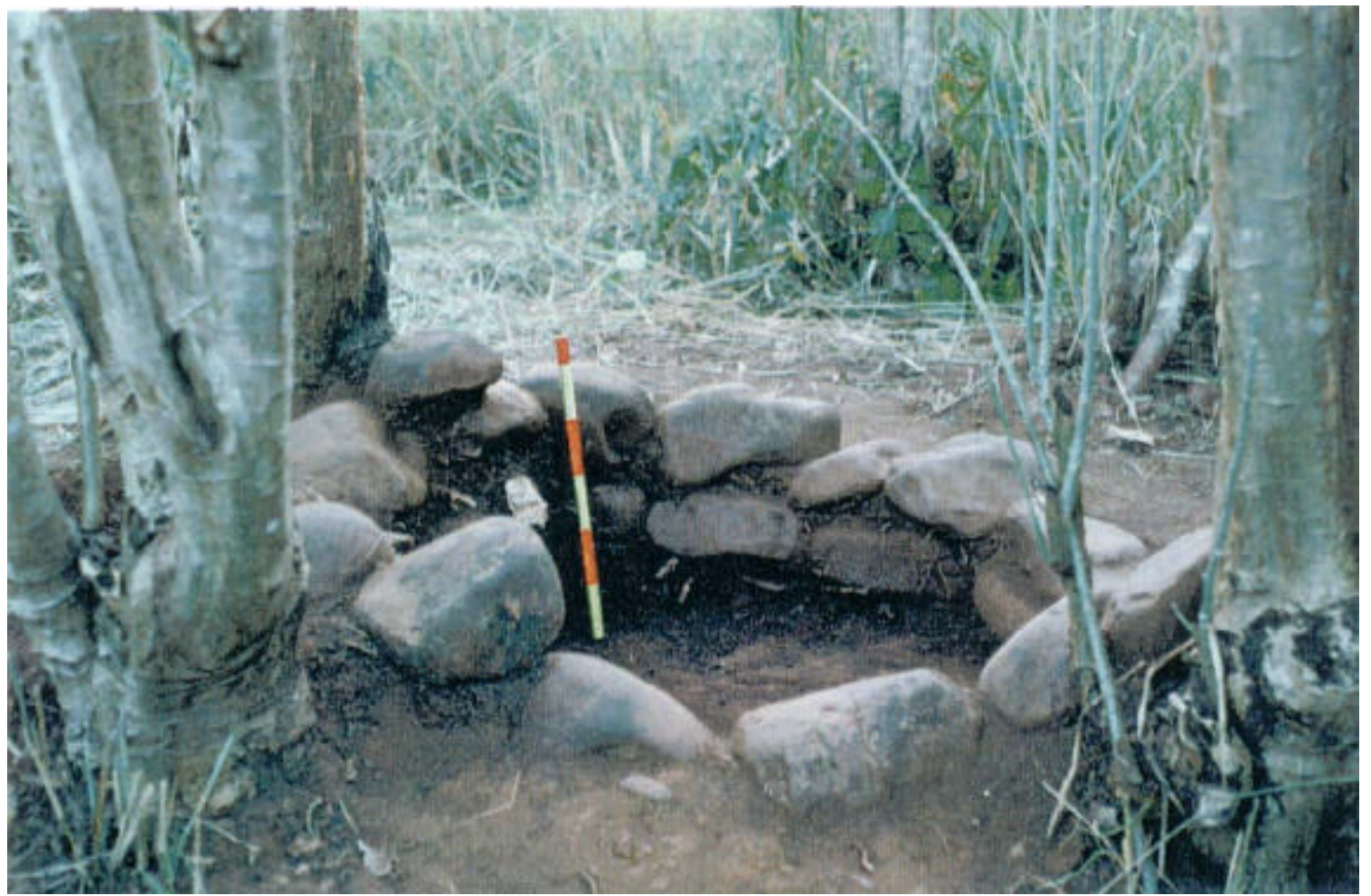

Foto 07: Fornalha de pedras, sítio Alameda dos Pinhões

(Foto: UFMG/Projeto de salvamento histórico-arqueológico na área da represa de Serra da Mesa). 


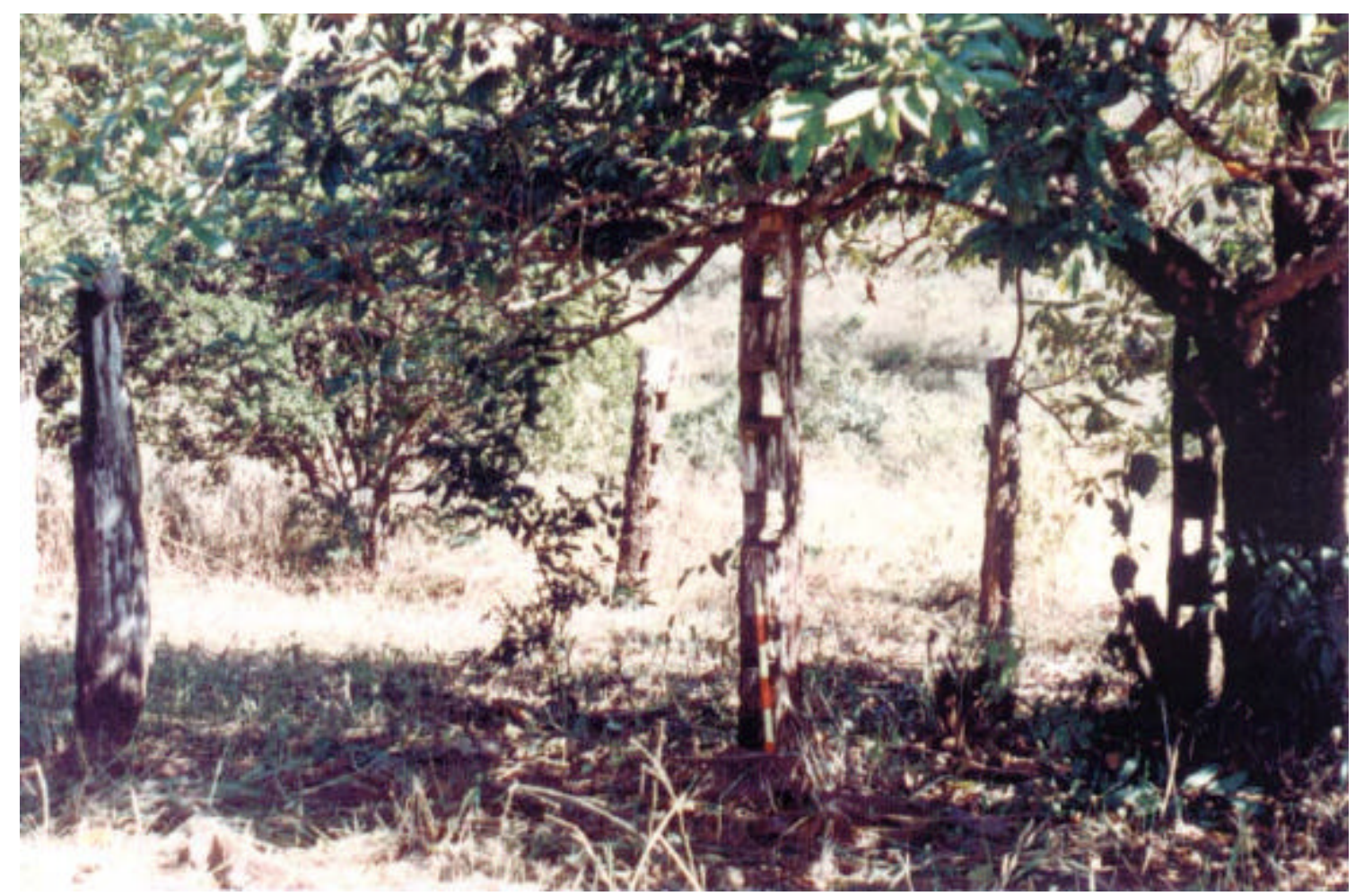

Foto 08: Vista geral dos vestígios de curral, sítio Alameda dos Pinhões

(Foto: UFMG/Projeto de salvamento histórico-arqueológico na área da represa de Serra da Mesa).

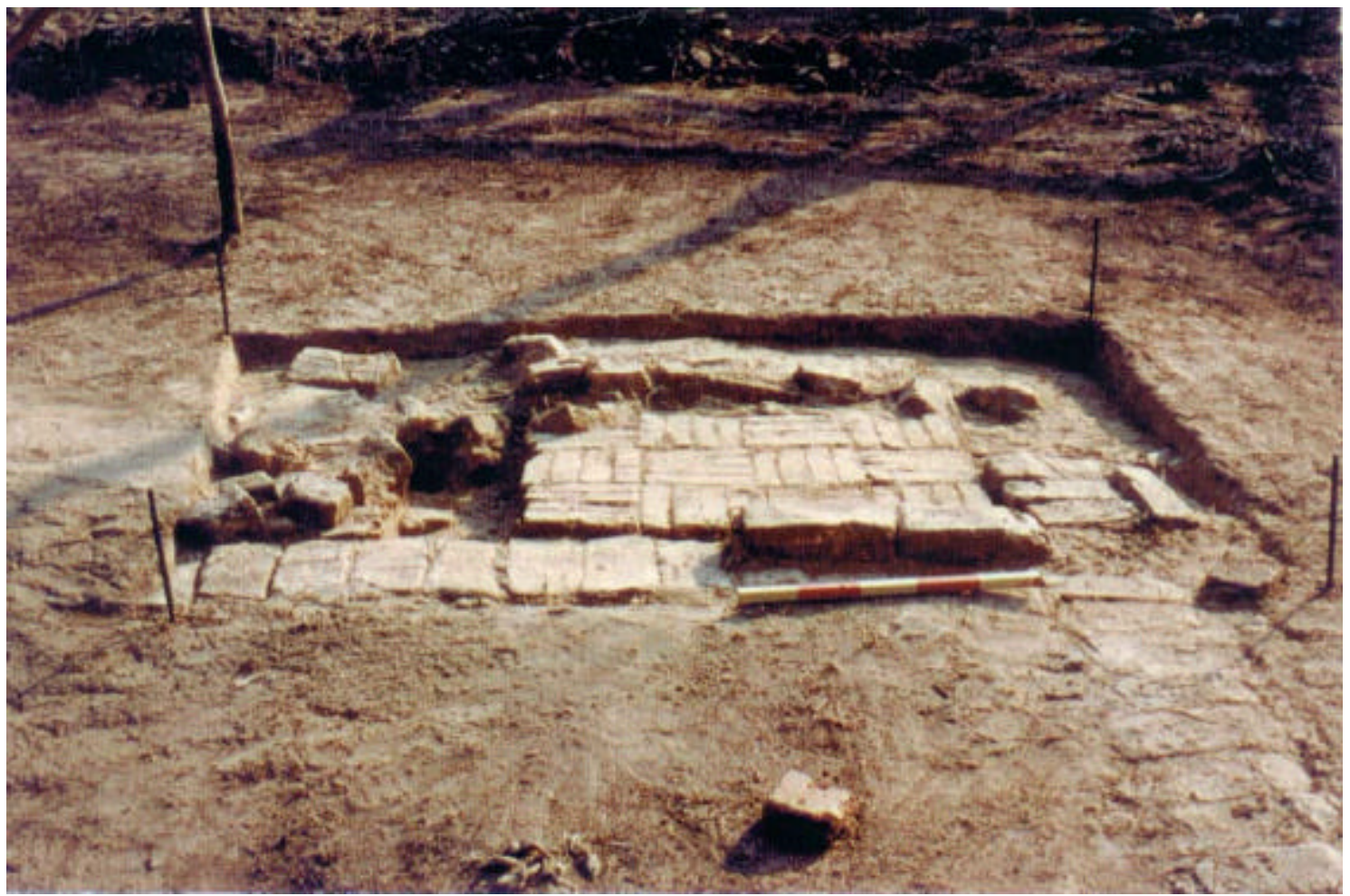

Foto 09: Vestígios de habitação, vista parcial. Sítio Imburana III

(Foto: UFMG/Projeto de salvamento histórico-arqueológico na área da represa de Serra da Mesa). 


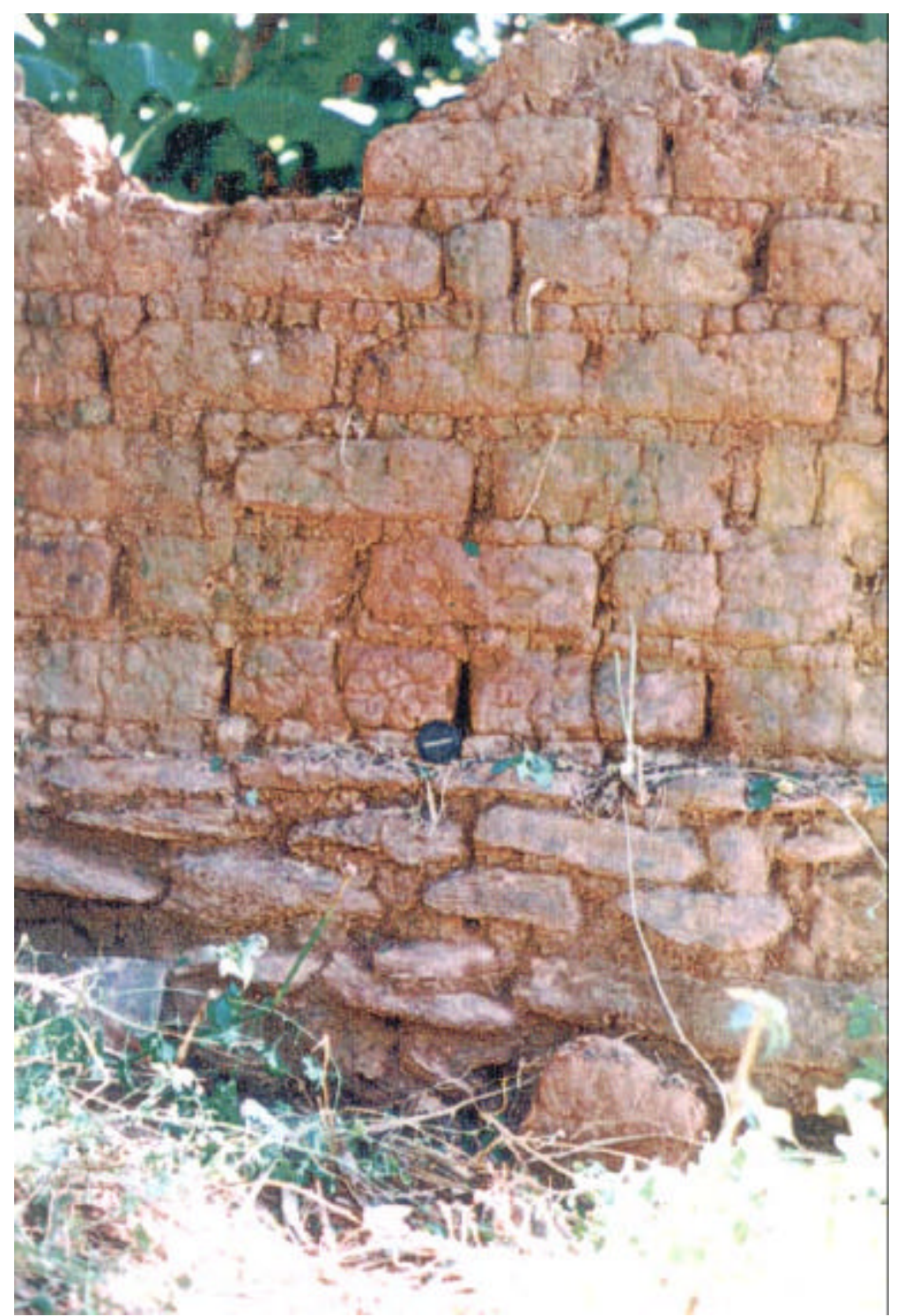

Foto 10: Vestígios de habitação, detalhe da parede e alicerce.

(Foto: UFMG/Projeto de salvamento histórico-arqueológico na área da represa de Serra da Mesa). 


\subsection{Sítios de mineração:}

Nesta categoria estão agrupadas uma variedade muito grande de unidades, que foram consideradas como vestígios de atividades mineradoras, denominadas lavras (denominação genérica para designar terrenos ou áreas de mineração). De acordo com os elementos encontrados na região, pôde-se verificar que estas lavras poderiam-se caracterizar como empreendimentos de porte variado, levados a cabo por uma só pessoa; por um pequeno grupo de indivíduos; ou ainda, por algumas dezenas ou centenas de escravos. O que pode servir como elemento diferenciador entre elas é exatamente a análise do tamanho do empreendimento, visto que

"revirar até a profundidade de um metro uma área de alguns hectares não é certamente trabalho para um ou poucos indivíduos. Principalmente se levarmos em conta que, para a lavagem do sedimento revirado, foi necessária a construção de açudes, de canais quilométricos e ainda o desvio de rios ou córregos de seus leitos originais. A natureza da atividade e as dimensões da sua realização exigiam trabalho coletivo sob comando unificado. Tal conclusão remete-nos à mão-de-obra escrava, mesmo porque o trabalho assalariado está descartado enquanto possibilidade histórica dominante, no período aqui tratado, qual seja o século XVIII."191

A foto 11 apresenta extensa área de "sedimento revirado", ou seja, de rejeitos de mineração muito antigos, sendo que, no caso, estes sedimentos estendem-se por vários quilômetros.

Os sítios de mineração apresentam-se como de grande interesse para esta pesquisa, uma vez que a inserção geográfica destes vestígios na paisagem constituiu-se em um elemento de primordial importância, desde a fase de prospecção até a análise do seu conjunto. Vale a pena ressaltar que a presença de água era um elemento essencial para a mineração no período colonial. Para a tecnologia disponível na época, a atividade mineradora poderia ser impossibilitada pela sua ausência. Dessa forma, é interessante destacar que estes sítios podem apresentar-se em conjuntos, que muitas das vezes se estendem por vários quilômetros, compreendendo assim, diversos sistemas de canais para transporte de água. Muitas vezes, 
esses canais faziam a sua captação em cursos d'água distantes, para depois trazê-la, por queda de declividade, até os pontos de lavagem do minério.

"Do ponto de vista qualitativo há que se destacar todo o conhecimento e domínio da natureza que está implícito na aparente simplicidade de cada um desses sistemas hidráulicos. (...) Baseados nos princípios fundamentais da hidrodinâmica, aqueles sistemas hidráulicos expressam hoje tanto as potencialidades quanto os limites da tecnologia mineradora setecentista e, portanto, a necessidade de seu resgate e de sua compreensão." 192

Diante da primordial necessidade de água na atividade mineradora, pode-se dizer que, por isso, naqueles sistemas que se constituiriam em unidades produtoras, a construção de açudes e canais tornava-se imperiosa, sobretudo quando era necessário o seu transporte por longas distâncias.

Portanto, na paisagem dos sítios de mineração é muito comum a implantação de canais cortando as vertentes. A principal característica destes canais é a mínima declividade, tanto para permitir o transporte de água para longas distâncias quanto para minimizar os riscos de desenvolvimento de erosão. Também com vistas de conter a erosão, em pontos de maior fragilidade, os canais apresentam-se revestidos por blocos rochosos, constituindo uma espécie de assoalho ou mesmo revestimento de suas paredes. Próximo à área onde foi construída a UHE de Serra da Mesa, na região do córrego Água Fria, (uma das áreas onde o relevo é mais movimentado), destaca-se um importante canal que se estende por vários quilômetros, e ainda hoje é importante marco na paisagem local. Ver foto 12.

Além do transporte de água, uma outra função muito importante para os canais era servirem como meios de escoamento da água dos leitos dos cursos d'água, para que se permitisse a mineração a seco no referido leito. Nestes casos, o canal era construído paralelo ao curso d'água que se pretendia minerar. Em muitos casos era necessário elevar-se o nível do solo através de aterros, para manter-se a declividade do canal. (Fotos 13 e 14)

${ }^{191}$ UNIVERSIDADE FEDERAL DE MINAS GERAIS. Salvamento histórico-arqueológico na área atingida pela represa da Usina de Serra da Mesa - Goiás, vol. 1, 1998, p.14. 


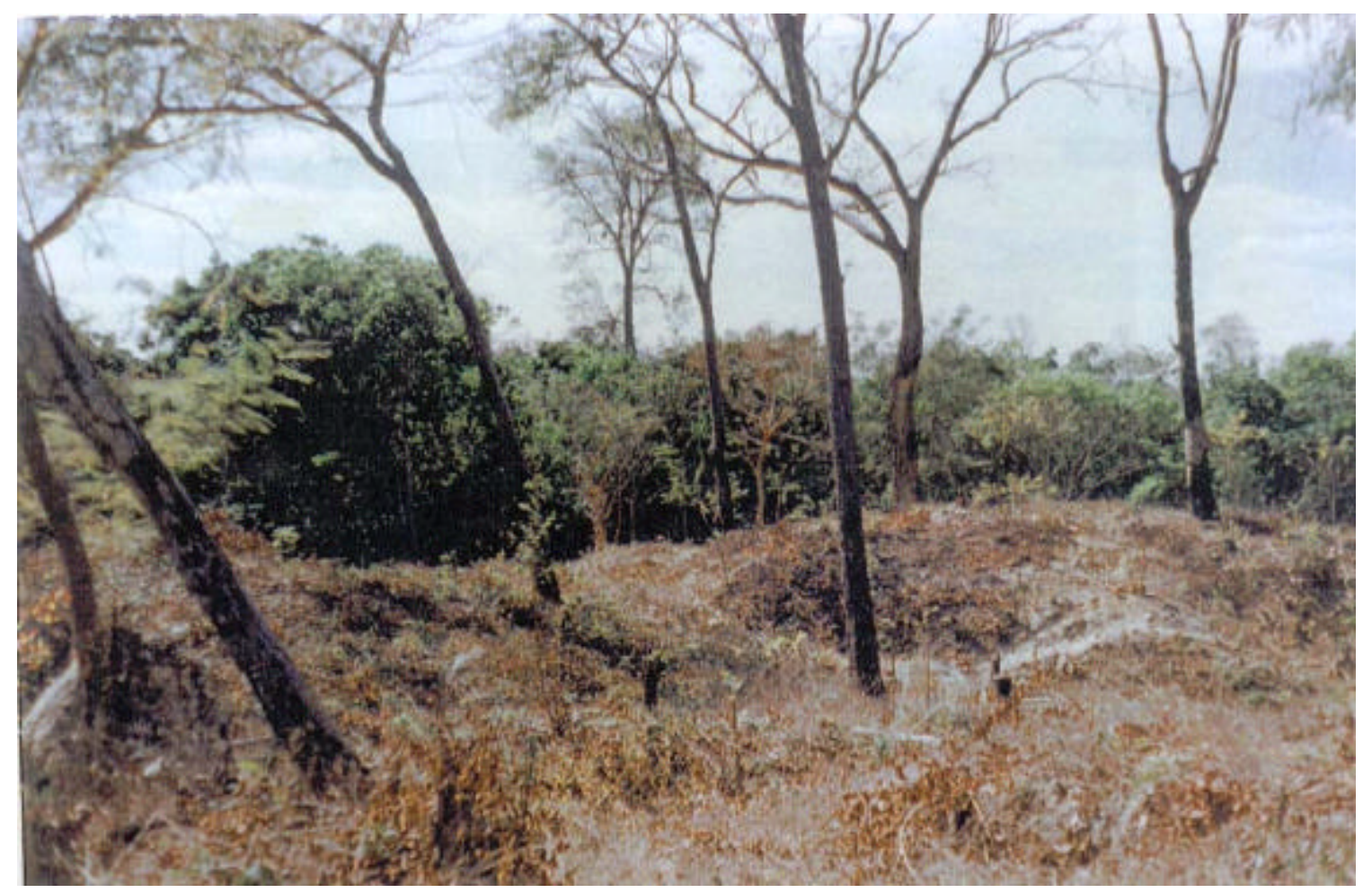

Foto 11: Extensa área antiga de "sedimento revirado" - Sítio Santa Rita

(Foto: UFMG/Projeto de salvamento histórico-arqueológico na área da represa de Serra da Mesa).

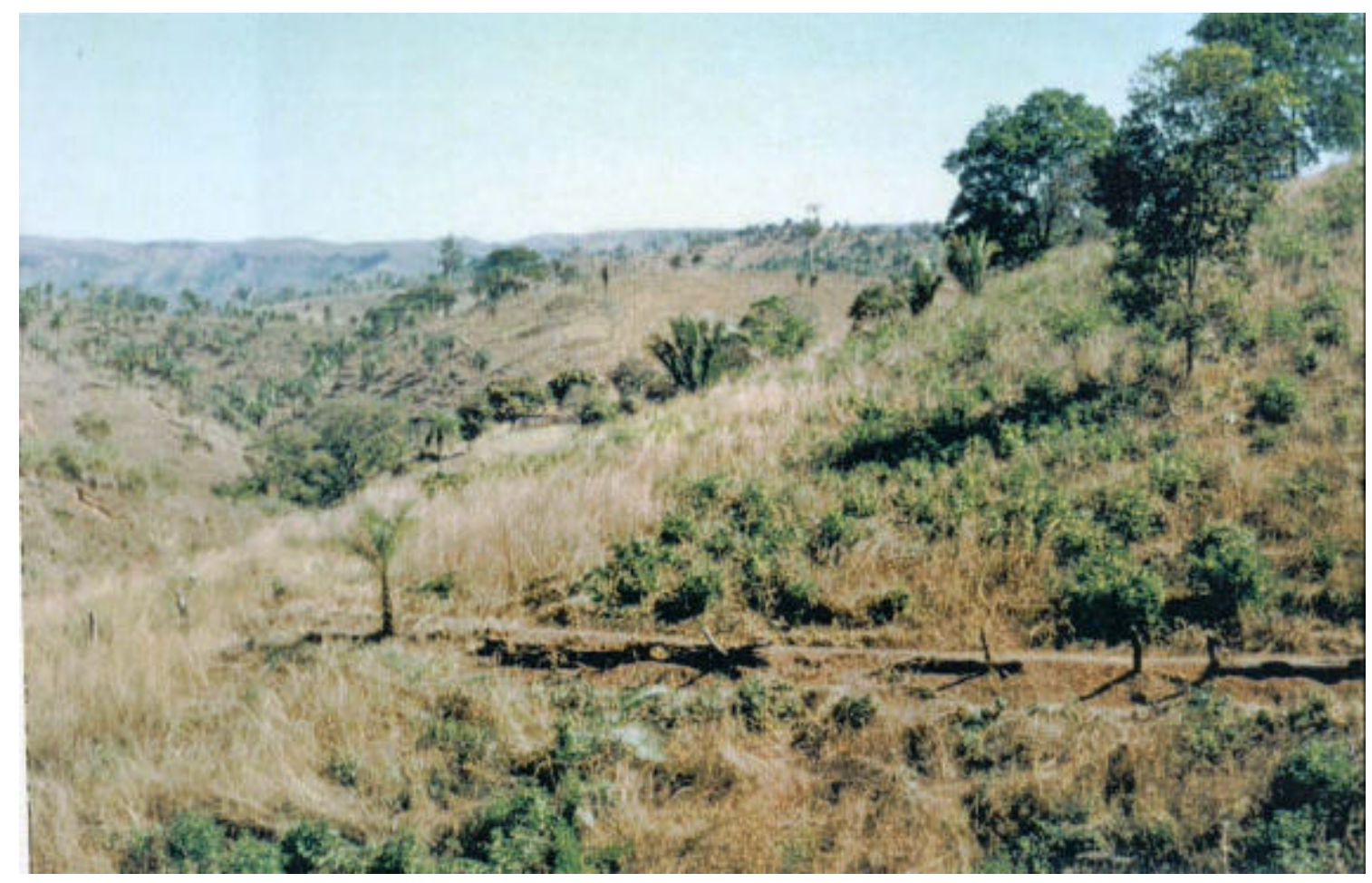

Foto 12: Vista parcial do canal cortando a vertente. Detalhe do escoramento de madeira, sítio Água Fria. (Foto: UFMG/Projeto de salvamento histórico-arqueológico na área da represa de Serra da Mesa).

${ }^{192}$ UNIVERSIDADE FEDERAL DE MINAS GERAIS. Salvamento histórico-arqueológico na área ..., vol. 1, 1998, p.15. 


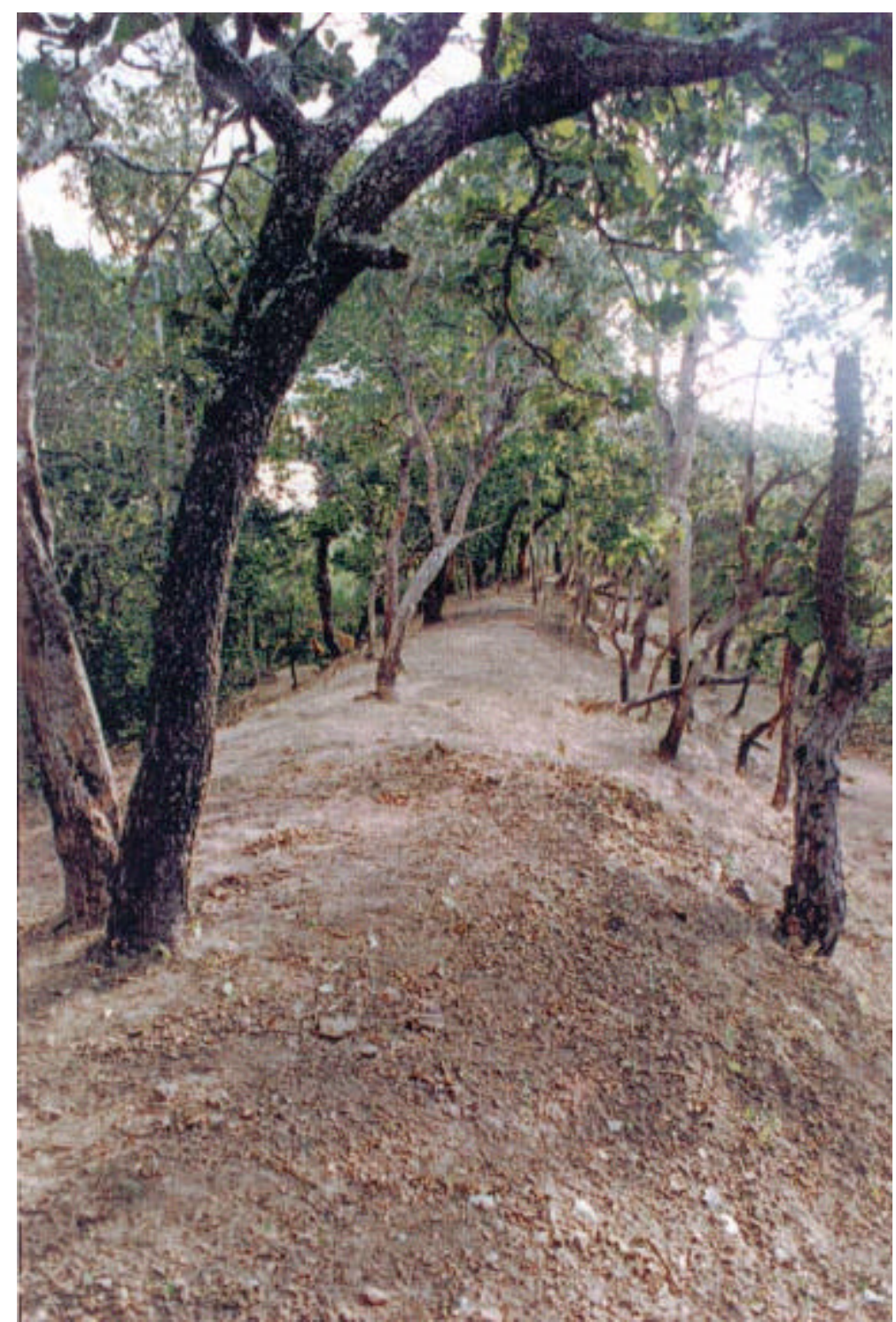

Foto 13: Vista de um aterro sobre o qual deveria passar um canal, que na atualidade não existe mais. Sítio: Complexo da Doralina.

(Foto: UFMG/Projeto de salvamento histórico-arqueológico na área da represa de Serra da Mesa). 


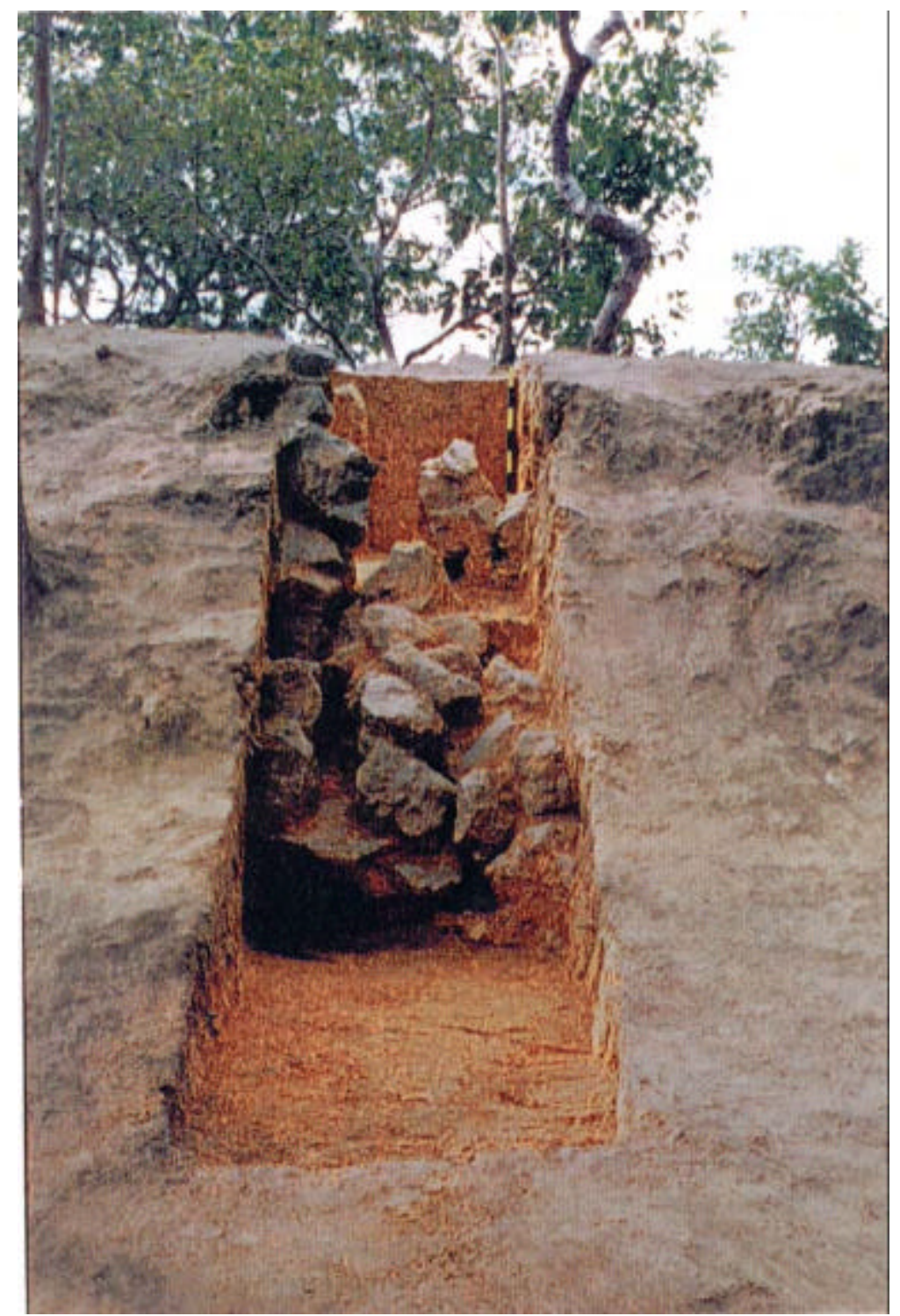

Foto 14: Vista lateral de sondagem realizada no aterro - estrutura de pedras para contenção. (Foto: UFMG/Projeto de salvamento histórico-arqueológico na área da represa de Serra da Mesa). 
Também comum nessas áreas de mineração são os açudes, cuja função poderia ser atuar como reservatórios de água para os mais diversos fins em um determinado local ou como possibilitador da elevação do nível de um determinado curso d'água para que esta pudesse ser utilizada em outros locais, de altimetria mais elevada. Igualmente importantes e constituintes dos mesmos sistemas são as barragens, sendo que muitas deles destacavam-se, tanto pela técnica quanto pela dimensão. A foto 15 mostra os vestígios de uma antiga barragem construída no córrego Santa Rita, importante núcleo urbano minerador no período colonial.

"Algumas dessas obras conseguiram resultados realmente impressionantes, permitindo o desvio de rios de médio porte por vários quilômetros como é o caso do rio Traíras na fazenda Água Parada, denominação oriunda dos efeitos provocados por esse tipo de desvio. Informações orais e bibliográficas não confirmadas apontam para a possibilidade de que o próprio rio Maranhão pode ter sido desviado de seu leito original na localidade denominada Cachoeira do Machadinho". ${ }^{193}$

“A 1/2 légua ao sueste de Água Quente, e 2 1/2 antes da união do rio das Almas com o Maranhão, fica a grande cachoeira do Machadinho, 'no lugar em que os antigos mineiros desviaram o rio Maranhão do seu leito original para o meterem por uma vala, com intenção de juntarem ouro no álveo descoberto.' Conta-se que os mineradores trabalharam durante um ano para desviar o curso do rio mas, por não calcularem bem o volume da água, no mesmo dia em que conseguiram a façanha, o dique arrombou-se e cobriu não só o antigo leito, como também as ferramentas e grande quantidade de ouro que havia sido apurada. Segundo Cunha Mattos, parte do dique ficou no leito do rio e 'faz a perigosa cachoeira do Machadinho, em que infalivelmente se abisma tudo que nela cai'."194

Em todos os casos o material utilizado baseava-se exclusivamente em blocos de pedras, madeiras e terra combinados nas mais diversas proporções. As fotos 16 e 17 mostram o que restou da Cachoeira do Machadinho. A foto 18 apresenta grande área de sedimento lavado às margens do rio Maranhão.

\footnotetext{
${ }^{193}$ UNIVERSIDADE FEDERAL DE MINAS GERAIS. Salvamento histórico arqueológico na área ..., vol. 1, 1998 , p. 16.

${ }^{194}$ UNIVERSIDADE FEDERAL DE MINAS GERAIS. Salvamento histórico arqueológico na área ..., vol. 1, 1998, p. 37.
} 


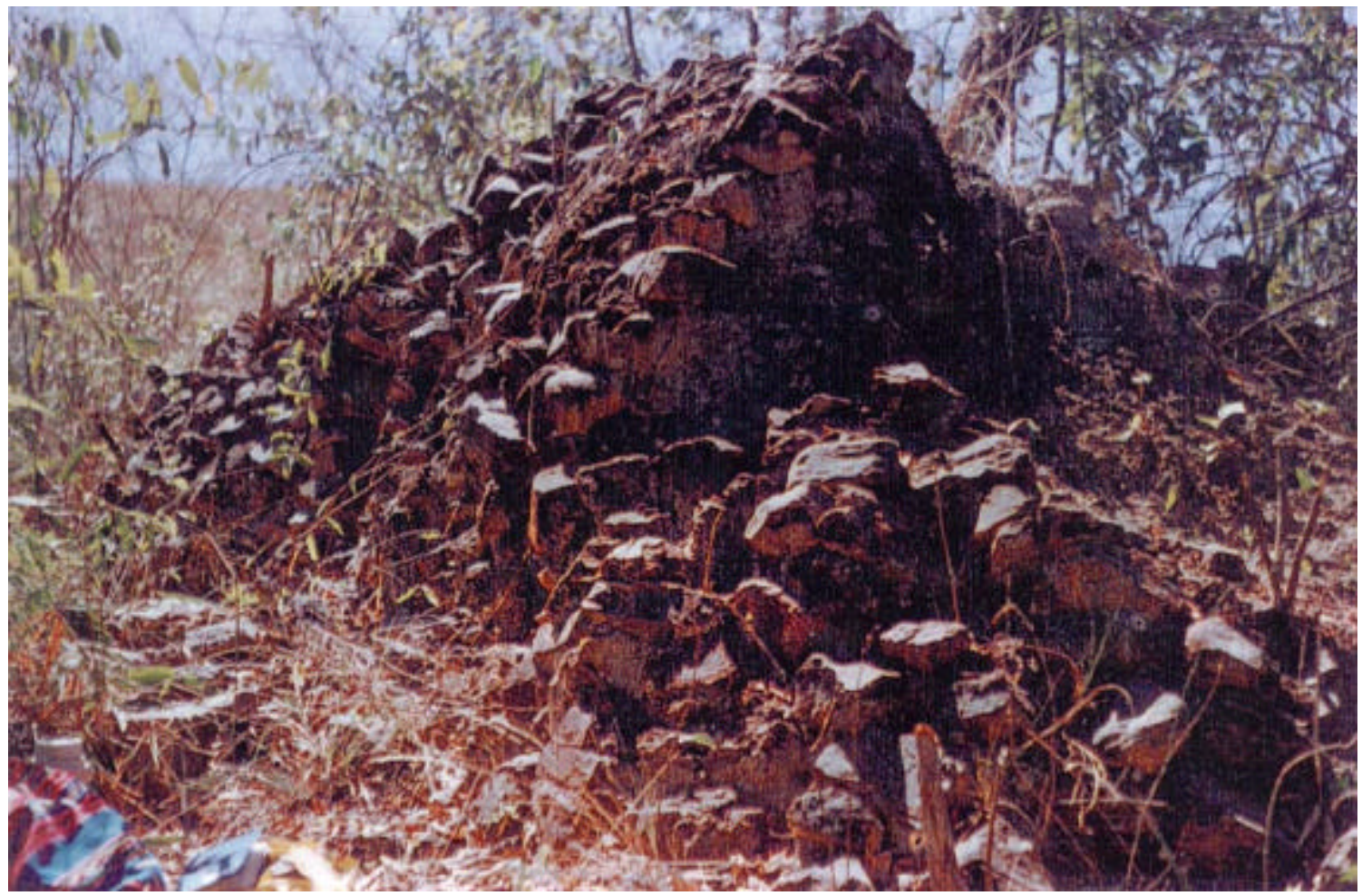

Foto 15: Vestígios de barragem de pedras no córrego Santa Rita.

(Foto: UFMG/Projeto de salvamento histórico arqueológico na área da represa de Serra da Mesa).

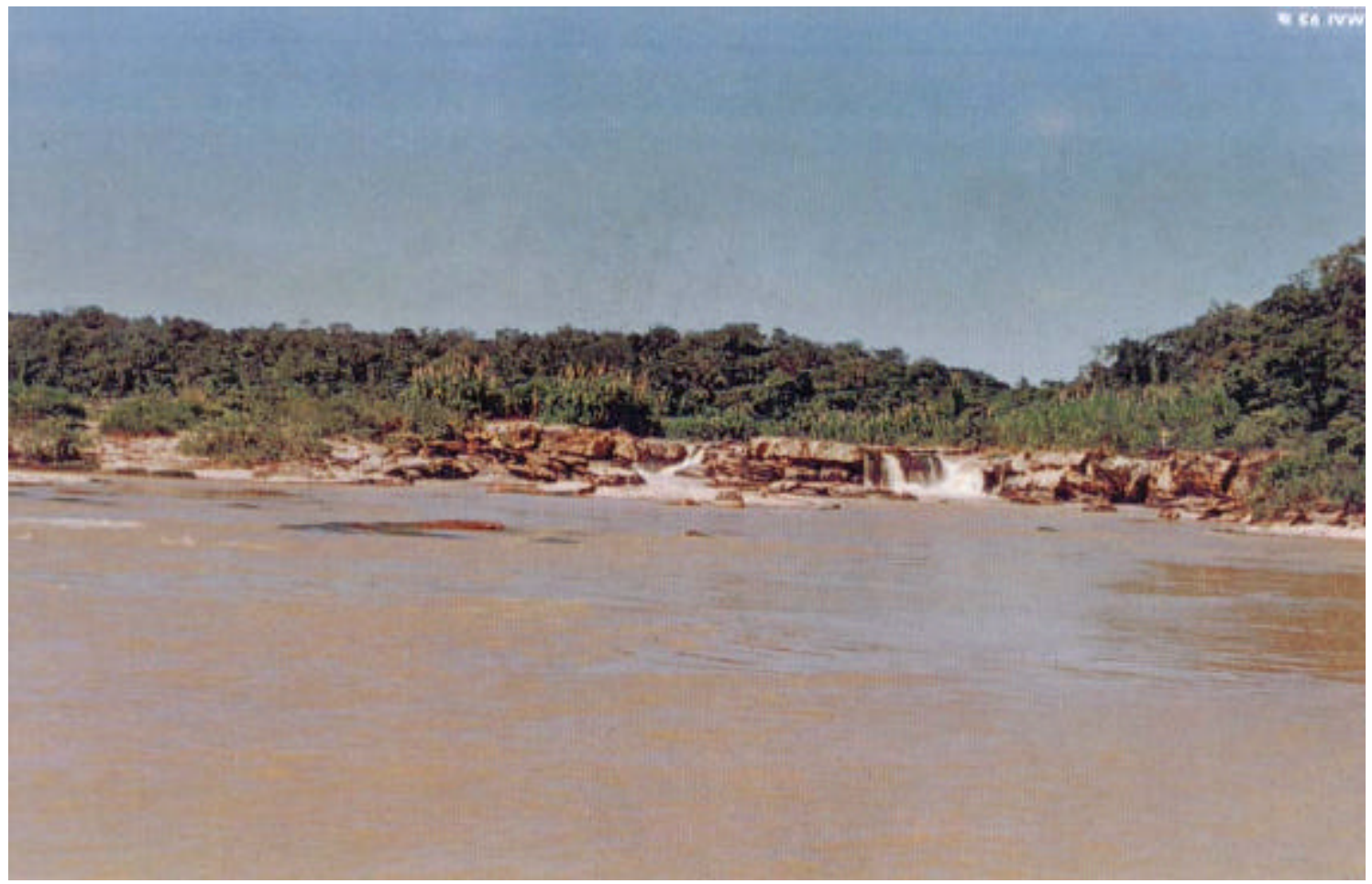

Foto 16: Vista geral da Cachoeira do Machadinho

(Foto: UFMG/Projeto de salvamento histórico arqueológico na área da represa de Serra da Mesa). 


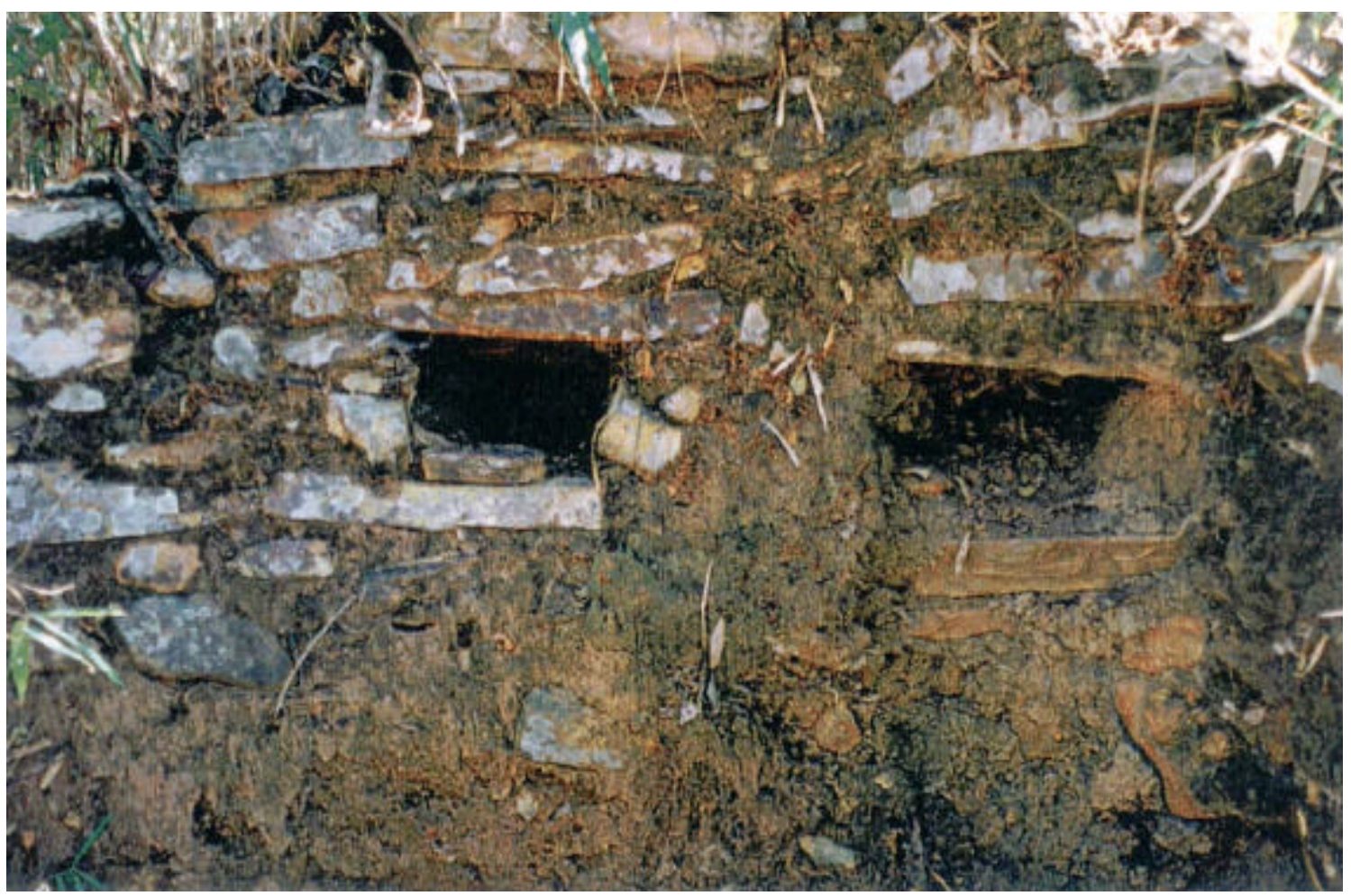

Foto 17: Detalhe de vestígio histórico da estrutura de construção da barragem da Cachoeira do Machadinho

(Foto: UFMG/Projeto de salvamento histórico arqueológico na área da represa deSerra da Mesa).

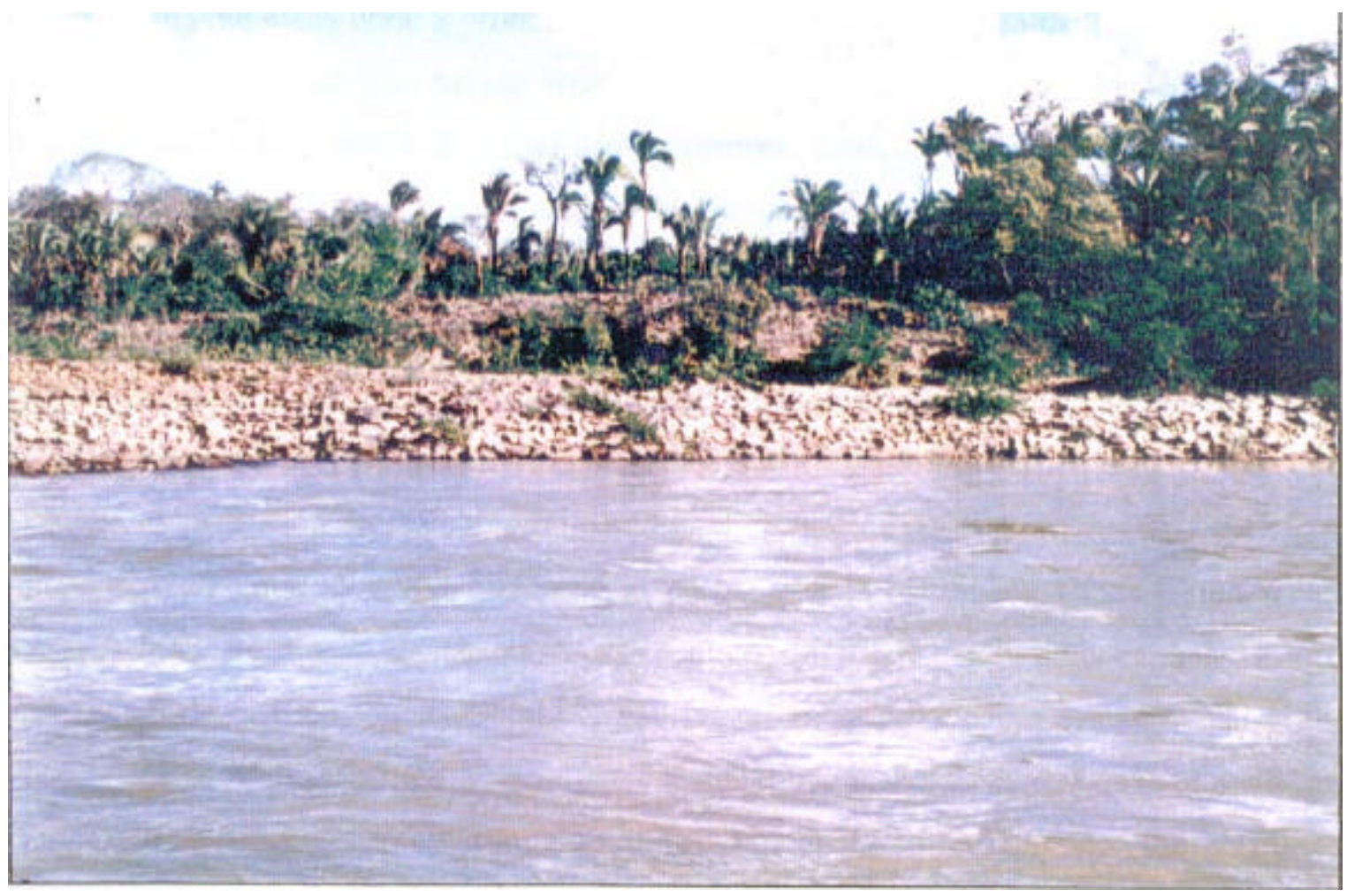

Foto 18: Importante área de sedimento lavado (rejeito de mineração) às margens do rio Maranhão.

(Foto: UFMG/Projeto de salvamento histórico arqueológico na área da represa de Serra da Mesa). 
Outro elemento importante identificado em grande parte dos sítios de mineração são os mundéus.

De forma mais objetiva, mas sem correr o risco de uma simplificação exagerada, podemos dizer que os mundéus eram poços ou tanques onde, através de um processo de decantação o mineral mais pesado (ouro elou diamante) ficava depositado no fundo, para um posterior trabalho de apuração. Do ponto de vista da sua construção, tanto poderiam ser grandes tanques com paredes de pedras e argamassa, como poderiam ser buracos escavados no leito de córregos e canais por onde a lama aurífera ou diamantífera deveria passar." "195

Os vestígios desse tipo de estruturas são localizados em áreas em que o empreendimento se apresentava mais promissor e/ou demandasse um tempo mais longo de exploração, justificando assim o grande emprego de mão-de-obra.

De qualquer forma, o que se observa é que os sítios de mineração estão inseridos na paisagem de forma muito peculiar. A começar pelo fato de que a sua ocorrência só se justifica e se confirma em áreas onde a probabilidade da ocorrência mineral almejada é real. Portanto, as áreas onde tais sítios ocorrem são áreas definidas, sendo que o contexto paisagístico passa a refletir a tendência econômica. Áreas sem ocorrência mineral de valor especializaram-se na atividade agropastoril, ou ficaram abandonadas ao longo do tempo.

Por outro lado, deve-se considerar também que as unidades mineradoras, desde o período colonial, constituem-se em fatores de grande degradação do meio ambiente. A atividade mineratória é predadora por natureza e traz consigo a falsa premissa de que os fins econômicos justificam os meios, implicando uma cultura de descaso ou despreocupação com o meio ambiente que sobrevive ao tempo, e perpetua-se por gerações. Dessa forma, observase ainda hoje, na região da pesquisa, um número ilimitado de indivíduos que se tornam garimpeiros de ocasião, ou seja, embora não façam dessa atividade a sua principal fonte de renda, estão sempre dispostos a garimpar ocasionalmente. Essas pessoas, de maneira geral, apresentam um descomprometimento muito grande com a questão ambiental, sem

\footnotetext{
${ }^{195}$ UNIVERSIDADE FEDERAL DE MINAS GERAIS. Salvamento histórico-arqueológico na área ..., vol. 1,
} 1998, p.16. 
preocupações ligadas à preservação ou conservação dos elementos naturais. Por isso, áreas mineradas estão sempre sujeitas a interferências negativas no ambiente.

Um dos elementos mais comuns nessas áreas, desde o período histórico, são as catas, que é a denominação dada aos buracos de onde é extraído o sedimento a ser lavado na mineração.

"Com dimensões e formas variadas encontram-se em quase todos os locais onde a atividade mineradora foi desenvolvida. Algumas chegam a atingir grandes dimensões, o que era determinado pela dimensão da 'mancha' de sedimento no qual havia sido detectada a ocorrência do mineral a ser extraído." $" 196$

Em áreas em que se encontram unidades mineradoras, a presença de catas é realmente comum. A profundidade e o tamanho delas são muito variados, sendo que em alguns locais, a sucessão de catas causa uma paisagem de desolamento; às vezes chegam a ser buracos gigantescos, dispostos lado a lado, além da presença de monturos do sedimento lavado que se espalha pelas proximidades.

Dessa forma, pode-se considerar que as alterações na paisagem são significativas. Em áreas de ocupação agropastoril, a interferência paisagística é sempre menos impactante. Nestes casos, a natureza faz parte do processo produtivo, o ciclo vegetativo das culturas, as manifestações climáticas, tudo leva a uma relação de maior proximidade e respeito entre os produtores e o meio ambiente. A produção se caracteriza como um processo, ao passo que na atividade mineradora a produção se caracteriza como uma atividade ocasional, de risco e essencialmente predatória.

\subsection{Sítios mistos:}

São considerados sítios mistos aqueles que apresentam, ao mesmo tempo, características das duas categorias anteriores, ou seja, evidências de atividades agropastoris e de atividades de mineração.

\footnotetext{
${ }^{196}$ UNIVERSIDADE FEDERAL DE MINAS GERAIS. Salvamento histórico-arqueológico na área ..., vol. 1, 1998, p. 17.
} 
O exercício de ambas as atividades num mesmo sítio, pode indicar duas situações distintas:

- primeiro, seria aquela em que o desenvolvimento das duas atividades ocorreram ao mesmo tempo, visando, provavelmente, à possibilidade de não prejudicar a atividade mineradora, com problemas de abastecimento de gêneros e víveres. Dessa forma, essas áreas teriam como função definida garantir o auto abastecimento para a atividade principal - a mineração - sendo inclusive incentivada pela Coroa através da política de concessão de terras agricultáveis na região.

- segundo, se a atividade agropastoril ocorreu nesses sítios, após o esgotamento da atividade mineradora, sendo, neste caso, muito difícil de se constatar se as atividades ocorreram concomitantemente, ou se uma sucedeu à outra.

De qualquer forma, os sítios que se caracterizaram por apresentar vestígios de ambas as atividades foram numericamente menores, o que leva a crer que a tendência comum era realmente a especialização. De maneira geral, é impossível precisar qual atividade foi dominante nestes sítios, ou qual delas se originou primeiro, uma vez que os vestígios encontrados são comuns a ambas. Ver fotos 19 e 20.

\subsection{Cemitérios:}

Os cemitérios das áreas rurais na região desta pesquisa apresentam características peculiares. Geralmente não se apresentam como áreas de destaque paisagístico; são manifestações culturais de aspecto modesto e sóbrio, sem construções ou adereços - muitas vezes identificados apenas por algumas cruzes de madeira, sobretudo se já estiverem abandonados. Quando ainda estão em uso, apresentam-se geralmente como uma área sem vegetação de médio ou grande porte e delimitado por uma cerca de madeira ou por um muro de pedras, cujo único objetivo é impedir a entrada de animais. 


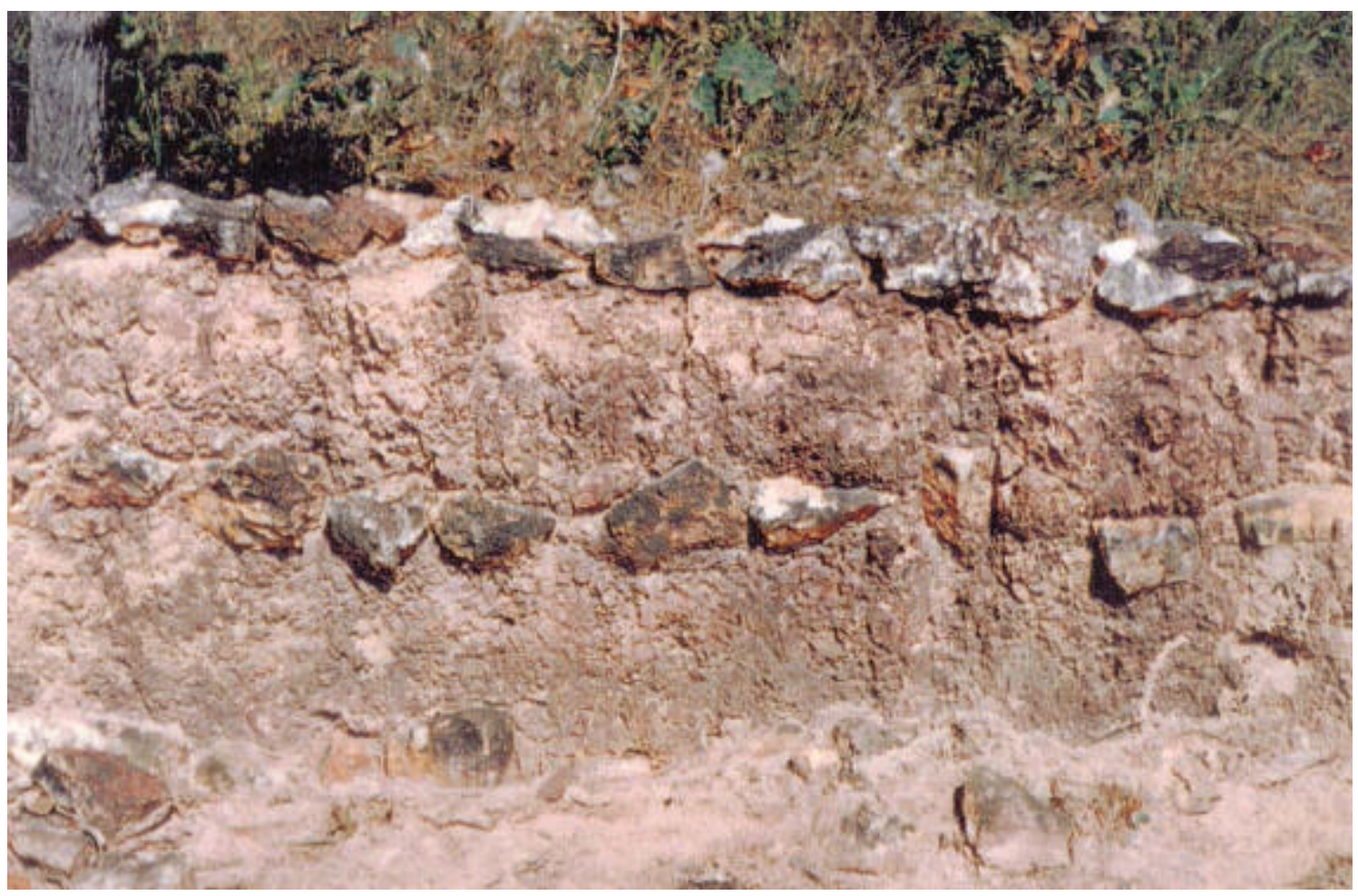

Foto19: Detalhe do curral que utiliza duas técnicas de construção: taipa e blocos rochosos

(Foto: UFMG/Projeto de salvamento histórico arqueológico na área da represa de Serra da Mesa).

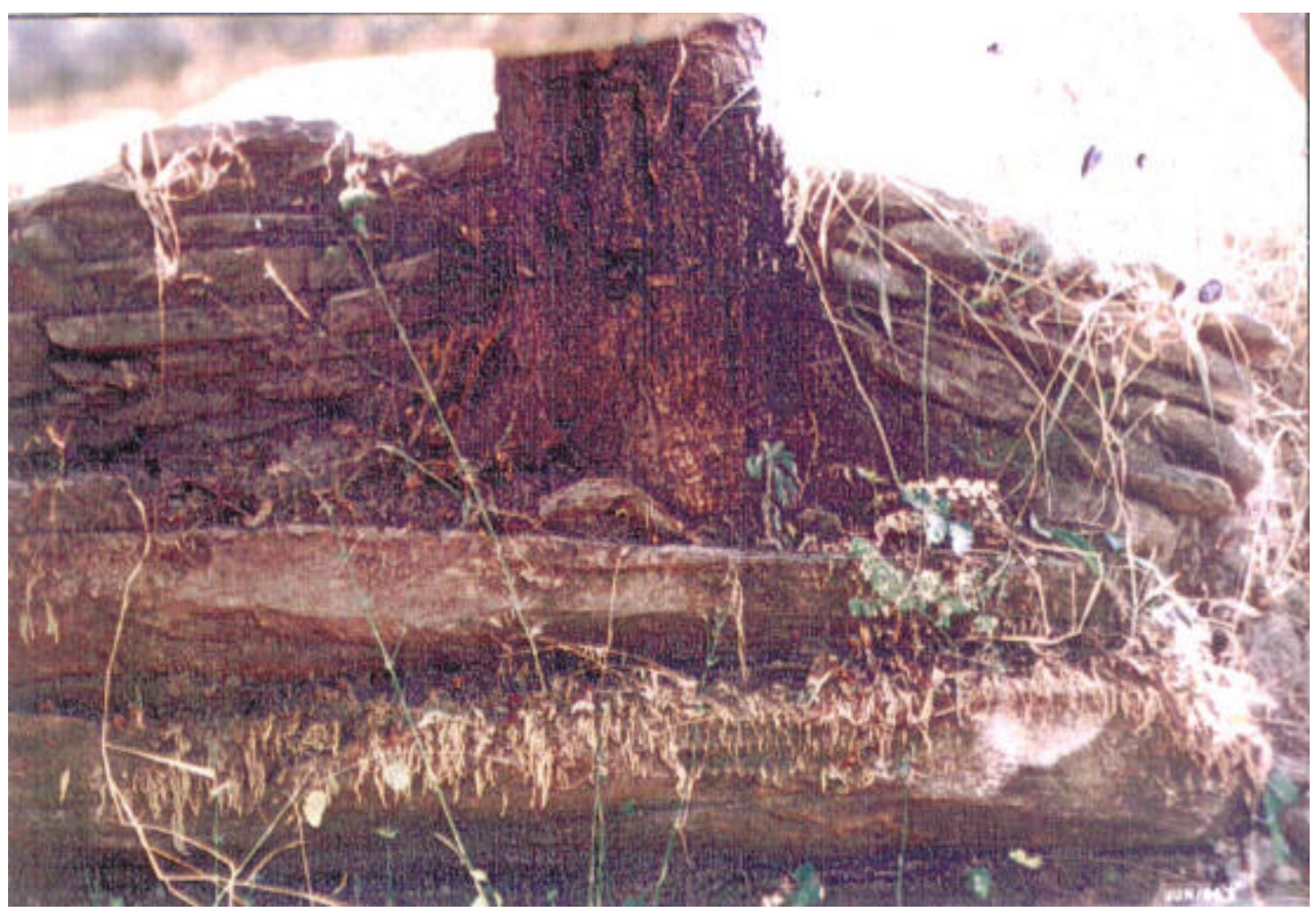

Foto 20: Detalhe do muro de pedras, sítio Quebra Pau.

(Foto: UFMG/Projeto de salvamento histórico arqueológico na área da represa de Serra da Mesa). 
"Não foi constatada nenhuma prática de construção de túmulos elou alguma forma de mausoléu. Tais práticas são, aparentemente, tardias na região e no meio rural não parece existir indicadores de que tenham se desenvolvido."197 Há que se considerar também o fato de que se trata de uma área rural, onde os hábitos são mais sóbrios e limitados pela questão econômica.

Um aspecto peculiar, no entanto, é a presença de uma vegetação denominada localmente como pitas ou piteira, que é muito utilizada como indicativo de sepulturas, pela sua longevidade e pela sua resistência a longos períodos secos. O abandono muitas vezes descaracteriza os sítios, e os cemitérios não são exceção. Assim, em muitos casos, a vegetação citada tornava-se o primeiro indício para a localização desses tipos de sítios. Sendo encontrada, procedia-se a uma vistoria mais minuciosa da área, o que levava geralmente a encontrar-se indícios dos sepultamentos, imperceptíveis num primeiro momento, quando não se estava atento à sua procura. Como exemplo dessas áreas, ver as fotos 21 e 22.

No entanto, mesmo os cemitérios que já estavam abandonados (do ponto de vista de receberem novos sepultamentos), ainda eram utilizados como locais de culto aos mortos, fato constatado in loco sobretudo por ocasião do dia de finados. Dessa forma, de acordo com a orientação da coordenação do projeto, optou-se por não se desenvolverem atividades de salvamento desses sítios que fossem além da documentação fotográfica e cartográfica, visto que o procedimento arqueológico poderia ser recebido como um desrespeito à memória daqueles que ali estavam sepultados.

"A realidade expressa nestes dados envolve ainda uma questão de cidadania que passa pelo direito de preservação de crenças e valores. É evidente que nenhum destes moradores que tem seus ancestrais, ou parentes imediatos ali sepultados, admitirá a possibilidade de ver seus mortos serem retirados e transformados em objetos de museus." "198

${ }^{197}$ UNIVERSIDADE FEDERAL DE MINAS GERAIS. Salvamento histórico-arqueológico na área ..., vol. 1, 1998, p. 18.

${ }^{198}$ UNIVERSIDADE FEDERAL DE MINAS GERAIS. Salvamento histórico-arqueológico na área ..., vol.1, 1998, p. 19. 


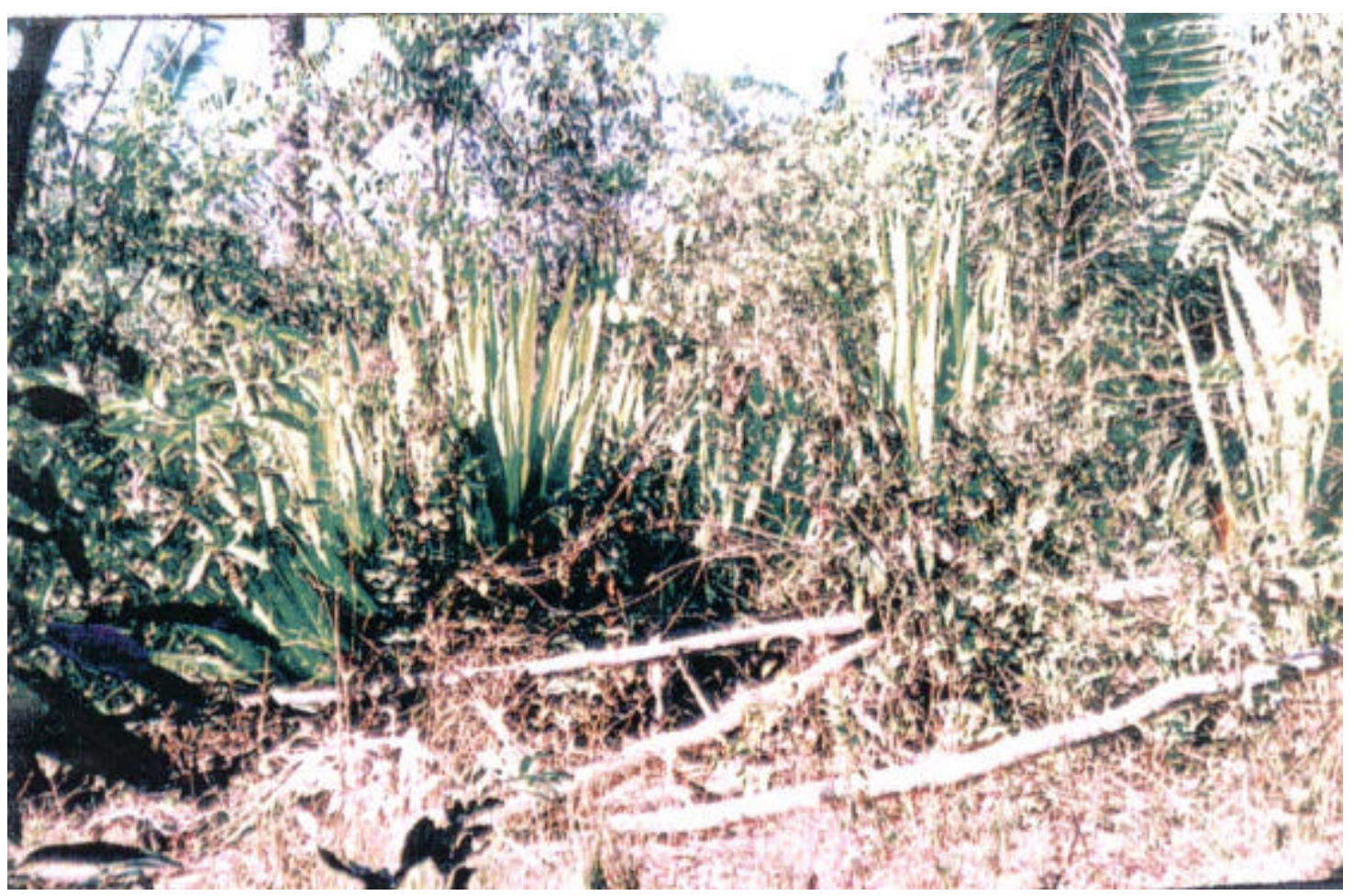

Foto 21: Vista de um provável cemitério abandonado.

(Foto: UFMG/Projeto de salvamento histórico arqueológico na área da represa de Serra da Mesa)

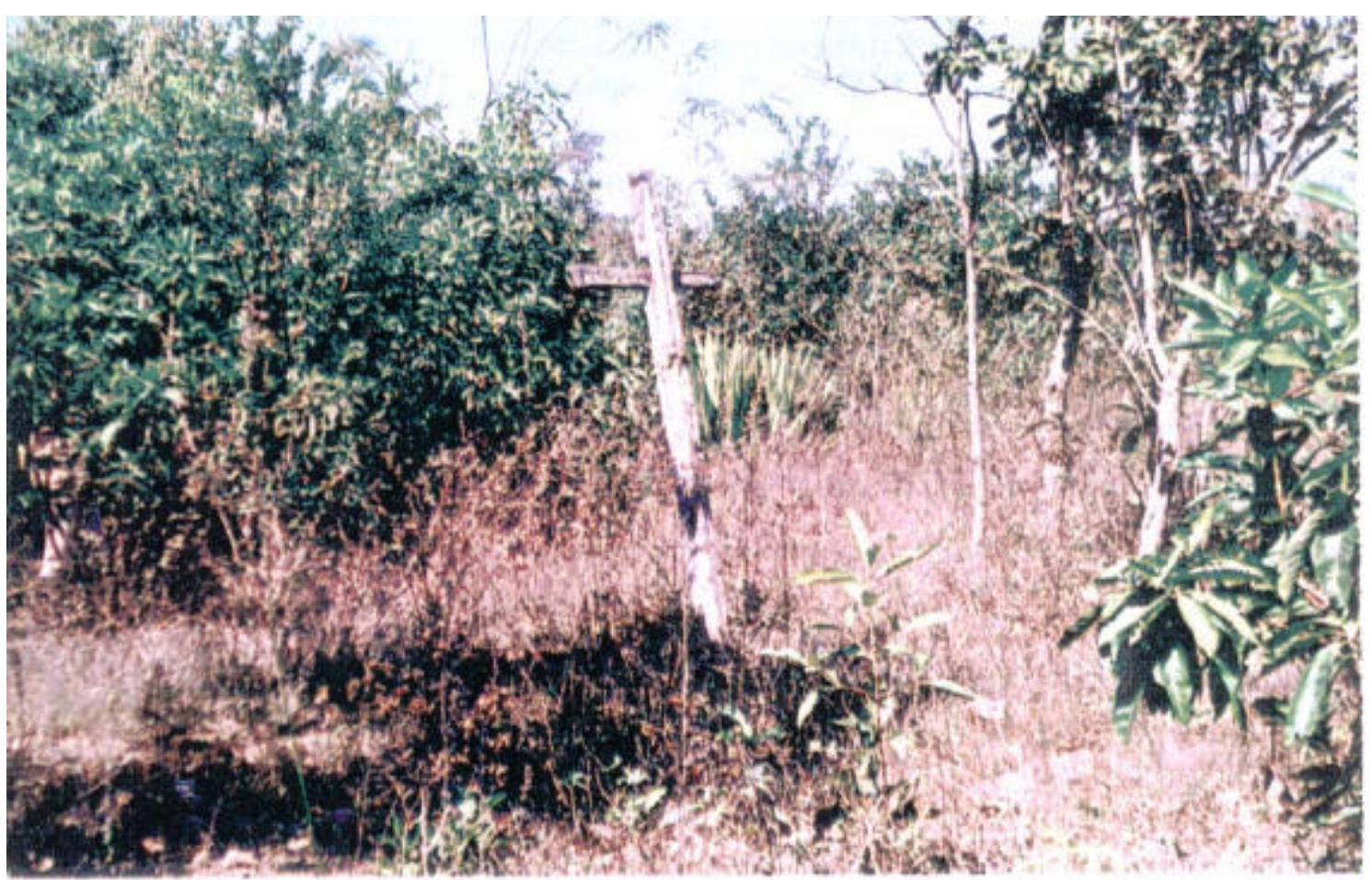

Foto 22: Vista do cemitério após a primeira limpeza.

(Foto: UFMG/Projeto de salvamento histórico arqueológico na área da represa de Serra da Mesa). 


\subsection{Presídios:}

Durante o período colonial, denominavam-se presídios os postos avançados do poder público colonial, que eram geralmente locais fortificados e que possuíam um regimento militar e um comando específico. A sua função era primordialmente a de funcionar como um entreposto de fiscalização das atividades econômicas, procurando coibir o contrabando de riquezas - sobretudo o ouro - ,a contenção de ataques indígenas aos aldeamentos e também como ponto de apoio às atividades agropastoris e ao povoamento em geral.

À época da colonização,

"a dificuldade de comercialização dos produtos imposta pela ausência de estradas ou vias de acesso aos centros consumidores, era vista como o principal entrave à expansão da produção agropastoril. Diante de tal preocupação a navegação dos rios Araguaia e Tocantins tornou-se objeto de vários pareceres e relatórios dos presidentes que tentavam, junto à Coroa, os recursos necessários para desobstruir estes canais de comunicação fluvial, através dos quais de chegava ao porto exportador do Pará. (...) Havia um consenso quanto à necessidade de se povoar aquela região. Supunham os defensores da navegação fluvial em Goiás que esta somente seria implementada se as margens do Araguaia e do Tocantins fossem suficientemente povoadas para oferecer apoio $e$ proteção aos navegantes. ",199

Dessa forma, foi assinada uma Carta Régia no ano de 1811, determinando uma série de medidas visando a incrementar o povoamento e a economia da província de Goiás, dentre elas a criação de presídios em distâncias proporcionais ao longo dos rios Araguaia e Tocantins.

“Em 1832 foi fundado o presídio do Xambá na confluência dos rios Maranhão e Bagagem. Tinha a finalidade de proteger os habitantes de Traíras e São José do Tocantins contra os ataques dos índios e apoiar a navegação, dando proteção e fornecendo víveres e combustivel às embarcações. $O$ presídio do Xambá, primeiramente fundado na foz do rio Bagagem, parece ter sido transferido posteriormente para as margens deste rio, em local a poucas léguas acima de sua foz. Um documento informa em 1849 que o destacamento do Xambá

${ }^{199}$ TIBALLI. A expansão do povoamento em Goiás - séc. XIX, 1991, p. 76. 
não se encontrava às margens do rio Maranhão. A isso acrescenta-se que na região do baixo curso do rio Bagagem nas fazendas conhecidas por Xambá e São Jacob, no município de Niquelândia - há vestígios de edificações antigas que presumivelmente sejam do quartel". ${ }^{200}$

"Os presídios eram construídos pelo governo local, com recursos vindos da Coroa a quem competia autorizar ou não a construção. As normas para o estabelecimento dos mesmos estavam previstas no regulamento de 1851. (...) $O$ artigo 25 deste regulamento estabelecia: 'Haverá em cada presídio huma Capela destinada para o culto do divino, huma casa para residência do comandante, hum quartel commum com casa forte para guarda de presos, hum paiol ou celleiro commum, huma casa com artifícios empregados na lavoura como moinho, monjolo, bandeira, hum telheiro em lugar próprio para guarda das embarcações, hum rancho espaçoso para passagens.' (...) Em sintese, os presídios foram a tentativa oficial mais objetiva no sentido de povoar a região compreendida entre os rios Araguaia e Tocantins e, apesar disso, esta região permaneceu desabitada até o final século XIX.",201

Diante da importância dessas instituições no período colonial (alguns deles puderam, ao longo do tempo, vir a se constituir em embriões de novos núcleos urbanos), é que se destaca o único vestígio de presídio encontrado na região da pesquisa: o Presídio de Santa Bárbara, embora se encontre fora dos limites da represa, portanto, estando fora de risco de se perder pela inundação. No entanto, do Presídio de Santa Bárbara restaram apenas alguns vestígios muito escassos, devido ao fato de se localizar em área de formação de pastagem, e portanto, tendo sofrido por várias vezes a ação do arado.

"No local, os vestígios perceptíveis são pequenos fragmentos de cerâmica, além da madeira vertical de uma cruz que teria restado do cemitério existente. Fragmentos melancólicos de um núcleo, que por informações documentais, parece ter sido muito dinâmico em épocas passadas. "202.

\footnotetext{
${ }^{200}$ UNIVERSIDADE FEDERAL DE MINAS GERAIS. Salvamento histórico arqueológico na área ..., vol. 1, 1998, p. 48-49.

201 TIBALLI. A expansão do povoamento em Goiás - séc. XIX, 1991, p. 84.

${ }^{202}$ UNIVERSIDADE FEDERAL DE MINAS GERAIS. Salvamento histórico-arqueológico na área ..., vol. 1, 1998, p. 19.
} 


\subsection{Diversos:}

Denominou-se de diversos a todos os sítios cujos vestígios não foram suficientes para definir a sua função de forma precisa, ou então vestígios de sítios muito peculiares, que não se encaixaram nas demais categorias. É o caso por exemplo dos vestígios de uma estrada calçada com lajes, nas proximidades do lugarejo denominado Nossa Senhora da Abadia do Muquém, município de Niquelândia, que recebeu a denominação de "Trilha dos Bandeirantes". 203 As características da construção evidenciam, "por um lado, o trabalho escravo e por outro a importância da própria via. No período colonial apenas as estradas reais recebiam este tipo de tratamento (requintado para a época), pelos altos custos envolvidos na sua construção. ,204

Outro elemento identificado e de grande significância, pela sua raridade, foram dois sítios onde foram encontrados fornos de queimar telhas. Como já foi dito, as telhas se constituíam em artigo de luxo, e mesmo fazendeiros de muitas posses não as utilizavam com freqüência em suas moradias. Assim, estes sítios assumem grande importância dentro do contexto da região, indicando uma atividade paralela muito dinâmica e provavelmente muito rentável. A foto 23 mostra o detalhe de um desses fornos.

A maioria dos vestígios desta categoria, no entanto, não permitem precisar a sua função. Mais comumente são encontrados aí diversos fragmentos de muros de pedras, a grande maioria degradada pela ação antrópica, sobretudo pelas atividades recentes ligadas à mineração e ao cultivo, como o arado, por exemplo, que se constitui-se num dos mecanismos mais importantes de destruição dos sítios arqueológicos, descontestualizando e fragmentando os objetos e destruindo os vestígios de superfície.

Outra tipologia que foi incluída nesta categoria é a dos portos. De acordo com o que foi citado anteriormente, a navegação fluvial era um importante meio de locomoção no período colonial, tendo sido efetivadas diversas empreitadas no sentido de se viabilizar a navegação na região, de forma efetiva e segura. Para tanto, a limpeza de determinados trechos

\footnotetext{
${ }^{203}$ Este sítio, embora de grande importância do ponto de vista histórico devido à sua originalidade, encontra-se fora da área de inundação, e foi portanto preservado, não sendo por isso objeto de pesquisa e/ou salvamento.

${ }^{204}$ UNIVERSIDADE FEDERAL DE MINAS GERAIS. Salvamento histórico-arqueológico na área ..., vol. 1, 1998, p. 19.
} 


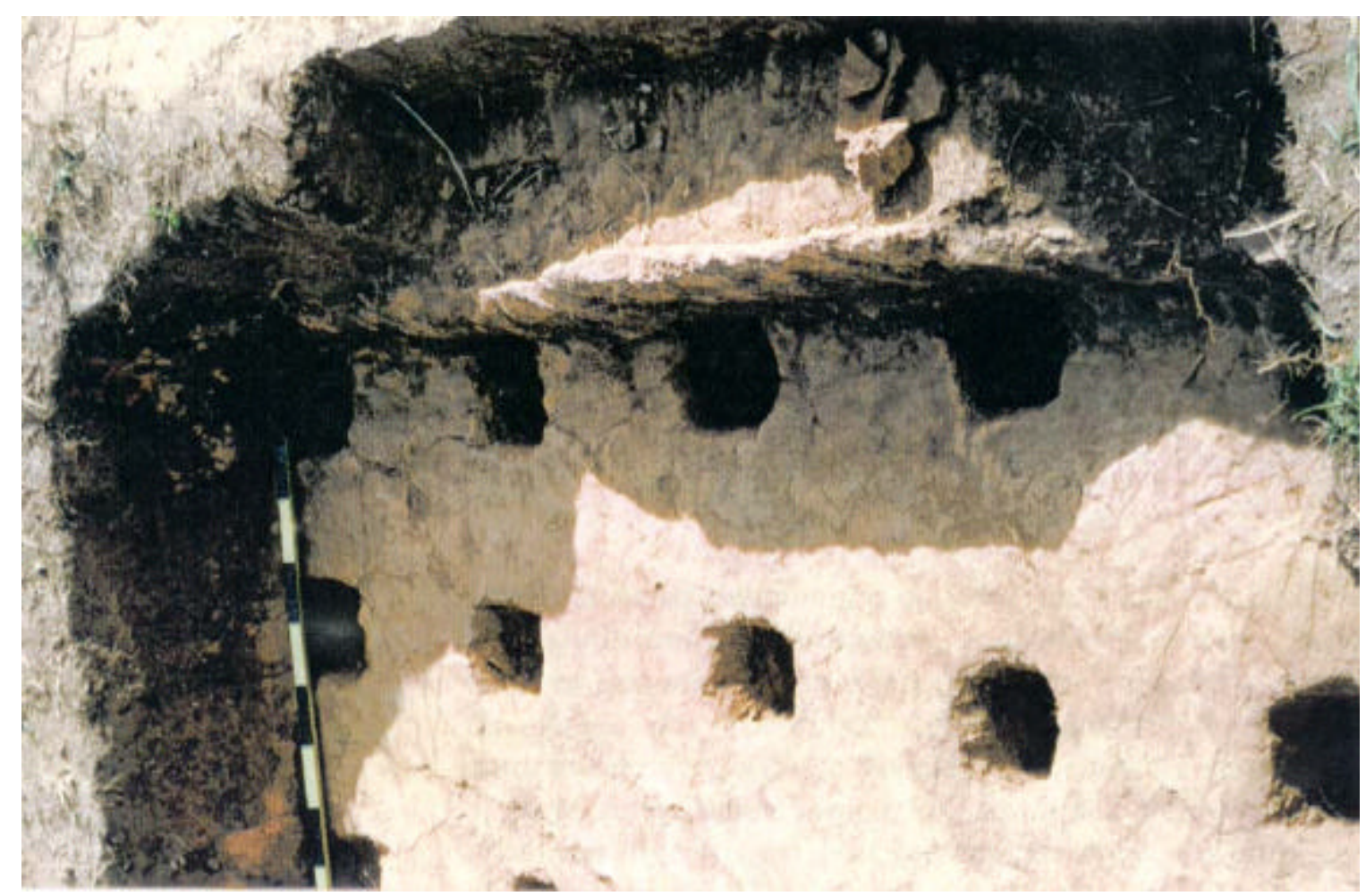

Foto 23: Detalhe da trempe de um forno de queimar telhas.

(Foto: UFMG/Projeto de salvamento histórico arqueológico na área da represa de Serra da Mesa).

e canais dos cursos dos rios mais volumosos se fazia necessária, bem como o estabelecimento de locais onde os barcos pudessem atracar com segurança, locais onde se estabeleceriam pontos de apoio à atividade de navegação. Constituíram-se assim os portos, embora rústicos, em locais onde habitualmente já se fazia a travessia de uma margem à outra, sendo portanto locais que já apresentavam um certo movimento de pessoas. Estes portos foram de grande interesse do governo colonial e posteriormente também do governo imperial. No entanto, com o passar do tempo, tais locais foram sendo abandonados bem como a navegação sistemática nesses rios.

O interesse na navegação era devido, sobretudo, às dificuldades de comunicação que a província apresentava em relação às áreas mais dinâmicas do país. 
"Várias medidas foram adotadas ao longo do século XIX com o intuito de desenvolver a navegação em Goiás e através desta, garantir a implementação da agropecuária e do comércio externo da capitania. Argumentavam os defensores de tais medidas que a comercialização com o Pará era economicamente mais vantajosa para Goiás do que o costumeiro comércio empreendido com a Bahia e o Rio de Janeiro. "205

Ocorre, no entanto, que, no período do auge da produção aurífera em Goiás, a navegação nos rios do norte estavam proibidas, com o intuito de coibir o contrabando e a evasão de riquezas.

"Para evitar o descaminho do ouro, em 1737 haviam tornado-se definitivamente proibidos quaisquer caminhos para os Goiases que não fossem o das bandeiras paulistas e suspensa a navegação dos Tocantins. (...) Em decorrência de ter sido suspensa a navegação do Tocantins, as relações entre o centro e $o$ norte tornaram-se precárias, as minas ficaram isoladas $e$ decaíram diversos arraiais localizados próximos daquele rio e de seus afluentes." 206

Embora para a Coroa tal medida se justificasse, do ponto de vista de garantir um controle maior sobre a produção mineral da província, para os habitantes de Goiás tal medida gerava uma série de dificuldades, sobretudo devido às dificuldades enfrentadas nos transportes e comunicações. De fato, os transportes por via terrestre eram inoperantes.

"O primeiro governador viajando do Rio a Vila Boa, através de Minas, gastou 85 dias na viagem, e seu sucessor, o Conde de S. Miguel, 72. Três meses era o tempo calculado para o transporte dos quintos. (...) Estas médias correspondem a viagens rápidas, com trocas freqüentes de animais, pois quando se tratava de tropas de carga o tempo se multiplicava." 207

A solução seria então modificar radicalmente as condições de transporte na região. Para tanto, fazia-se necessário permissão para a navegação dos rios em direção ao norte, fato que foi negado veementemente no sentido de proteger os interesses da Coroa. No entanto, tal

\footnotetext{
205 TIBALLI. A expansão do povoamento em Goiás - séc. XIX, 1991, p. 74.

${ }^{206}$ UNIVERSIDADE FEDERAL DE MINAS GERAIS. Salvamento histórico arqueológico na área ..., vol. 1, 1998 , p. 45.

${ }^{207}$ PALACIN. Goiás, 1722-1822, estrutura e conjuntura numa Capitania de Minas, 1972, p. 144-145.
} 
proibição não era suficiente para impedir o contrabando na capitania, que via escoar ilegalmente grande parte das riquezas aí produzidas.

No entanto, com o declínio da mineração, a inibição da navegação já não fazia sentido. "Mas a proibição estava chegando ao fim, nem teria mais sentido quando o ouro do norte se acabava por si mesmo e triunfava no campo da teoria econômica a doutrina do livre comércio. Assim passava-se da proibição aos incentivos”. ${ }^{208}$ A possibilidade de se comercializar com o Pará era forte e atraente, e diante da decadência da produção do ouro, abria-se como possibilidade de dinamizar a economia goiana.

A pesquisa identificou, na região de Serra da Mesa, os vestígios de dois desses antigos portos: o Porto da Lavra e o Porto do Bagagem, embora em nenhum dos dois tenham sido encontrados quaisquer vestígios de construção. Somente a tradição oral indica a utilização desses locais como tendo sido utilizados como portos no passado. Em pelo menos um deles, no caso o Porto do Bagagem, o local ainda é utilizado como ponto de travessia do rio do mesmo nome, tratando-se de uma área isolada, sem pontes próximas nem estradas de fácil acesso.

\subsection{Núcleos urbanos:}

Como já foi discutido anteriormente, na região do interior de Goiás, um grande número de vilas e aldeias surgiram no período colonial em função da atividade mineratória. "Há ouro e água, isto basta. Este será o critério com que irão surgindo os demais arraiais. ${ }^{209}$ No entanto, com o esgotamento da produção aurífera, a maioria destes núcleos entrou em decadência, levando muitos deles a desaparecer. De acordo com Tiballi ${ }^{210}$,

“as aldeias, assim como os presídios possuíam grande mobilidade. Foram criadas, instaladas, extintas, transferidas e recriadas desde os primeiros tempos da colonização. Em Goiás

\footnotetext{
${ }^{208}$ PALACIN. Goiás, 1722-1822, estrutura e conjuntura numa Capitania de Minas, 1972, p. 146.

${ }^{209}$ PALACIN. Goiás, 1722-1822, estrutura e conjuntura numa Capitania de Minas. 1972, p. 29.

210 TIBALLI. A expansão do povoamento em Goiás - séc. XIX, 1991, p. 89.
} 
este processo existiu desde 1741 e foi intensificado na segunda metade do século XVIII."

Ainda de acordo com a autora,

"a decadência do ouro foi devastadora sobre os arraiais e o comércio. Os núcleos urbanos remanescentes do ouro não constituíram uma continuidade das antigas cidades. Nada restara dos antigos arraiais senão alguns edificios e uma pequena parcela da população.",11

Dessa forma, poucos foram os vestígios de núcleos urbanos encontrados na região de Serra da Mesa, com destaque para as ruínas de Água Quente, Cocal, Traíras e Santa Rita.

Ocorre que a maioria destes núcleos urbanos encontra-se fora do risco de inundação, sendo a única exceção o povoado de Santa Rita, cuja situação geográfica coloca em risco uma parte das ruínas - aquelas localizadas na parte mais baixa das vertentes que margeiam o córrego do mesmo nome, afluente do rio do Peixe. As ruínas que se situam na meia vertente e acima estão fora da área de inundação.

Trata-se de um belo sítio arqueológico, cujas evidências mais expressivas são um riquíssimo conjunto de muros de pedras, vestígios de alicerces, arruamentos e uma capela semi-destruída pela ação do tempo. Os muros, como é padrão comum na região, são de baixa altura - raramente alcançam um metro - e ao que tudo indica serviam para delimitar propriedades e definir as áreas de circulação (arruamentos). As fotos de $\mathrm{n}^{\circ} 24$ a 30 mostram vários aspectos deste conjunto de ruínas.

Santa Rita foi um importante núcleo urbano no período colonial, sendo que vários autores fizeram referências a ele - considerando-se, no entanto, que o que se denomina de núcleos urbanos são, na realidade, pequenas aldeias, constituindo simplesmente, na maioria das vezes, um aglomerado de casas modestas, cujo objetivo maior era dar apoio à atividade principal - no caso, a mineração.

${ }^{211}$ TIBALLI. A expansão do povoamento em Goiás, séc. XIX, 1991, p. 109. 
$\mathrm{Na}$ perspectiva de Couto de Magalhães, Santa Rita era um arraial que merecia destaque:

"Santa Rita está colocada nas encostas meridionais da Serra do Acaba-Saco; é linda, porém povoação pequena: a verdura das árvores que crescem pelos quintais, e o luxuriante da vegetação contrastam agradavelmente com a cor branca das casas. A indústria de seus habitantes consiste, principalmente, na criação do gado vaccum; a agricultura limita-se à plantação de gêneros da terra. O número do gado é de 9.000 para uma população de 2.000 habitantes, tendo estes seus principais estabelecimentos nas bacias dos rios Peixe e Vermelho."

Pohl $^{213}$, no entanto, conheceu o arraial quando este já se encontrava em decadência e, portanto, foi menos enfático ao descrever o local :

"Pelas três horas da tarde, chegamos a Santa Rita, que é um lugar muito pequeno, em visível decadência. Várias casas já desmoronaram e muitas estão abandonadas. Restam ainda umas trinta, formando um longo quadrilátero. No centro, está a igreja. Por causa de suas plantações, o Comandante e o Vigário de Anta moram atualmente neste povoado. Esta localidade é mais velha do que Anta e já foi muito célebre em razão da rica produção de ouro. Agora, por não haver negros, por falta de braços, as lavras de ouro estão inteiramente descuradas e abandonadas."

Os vestígios da mineração ainda estão presentes na paisagem local, devido a grandes áreas de sedimento revirado, rejeitos típicos dessa atividade. Também foi identificado um conjunto de currais de pedra em área próxima, confirmando a atividade pecuária como atividade de suporte ou de sucessão da primeira. Santa Rita constitui-se assim num marco paisagístico da região de Serra da Mesa, e o descaso das autoridades no momento atual coloca em risco todo esse patrimônio cultural, uma vez que, pertencendo ao município de Niquelândia, a aldeia não recebe nenhuma atenção especial: as ruínas encontram-se em completo abandono, não havendo nenhum programa em nível municipal ou estadual que vise a preservação dos mesmos. A capela é o vestígio mais bem conservado, muito embora já esteja quase que completamente descaracterizada pelo abandono. Parte da construção desabou e a reconstrução se deu de forma descriteriosa; o telhado foi completado com telhas de

${ }^{212}$ UNIVERSIDADE FEDERAL DE MINAS GERAIS. Salvamento histórico arqueológico na área ..., vol. 1, 1998, p. 38. 
amianto, o madeirame está apodrecido e o risco de desabamento é eminente. Como quase não há moradores no local, a capela não tem um pároco permanente, sendo que a sua chave (ainda a original), bem como os cuidados da sua manutenção estão sob responsabilidade de uma moradora local. Ver fotos $n^{\circ} 24,25,26$ e 27.

Santa Rita chama a atenção por ser um dos poucos vestígios concretos da ocupação da região nos séculos anteriores, e no entanto pode-se observar que tal fato não é considerado como relevante diante dos olhos das autoridades locais. Testemunho vivo da ocupação colonial e da atividade mineradora, esse arraial deveria ser constantemente protegido como monumento do patrimônio cultural brasileiro.

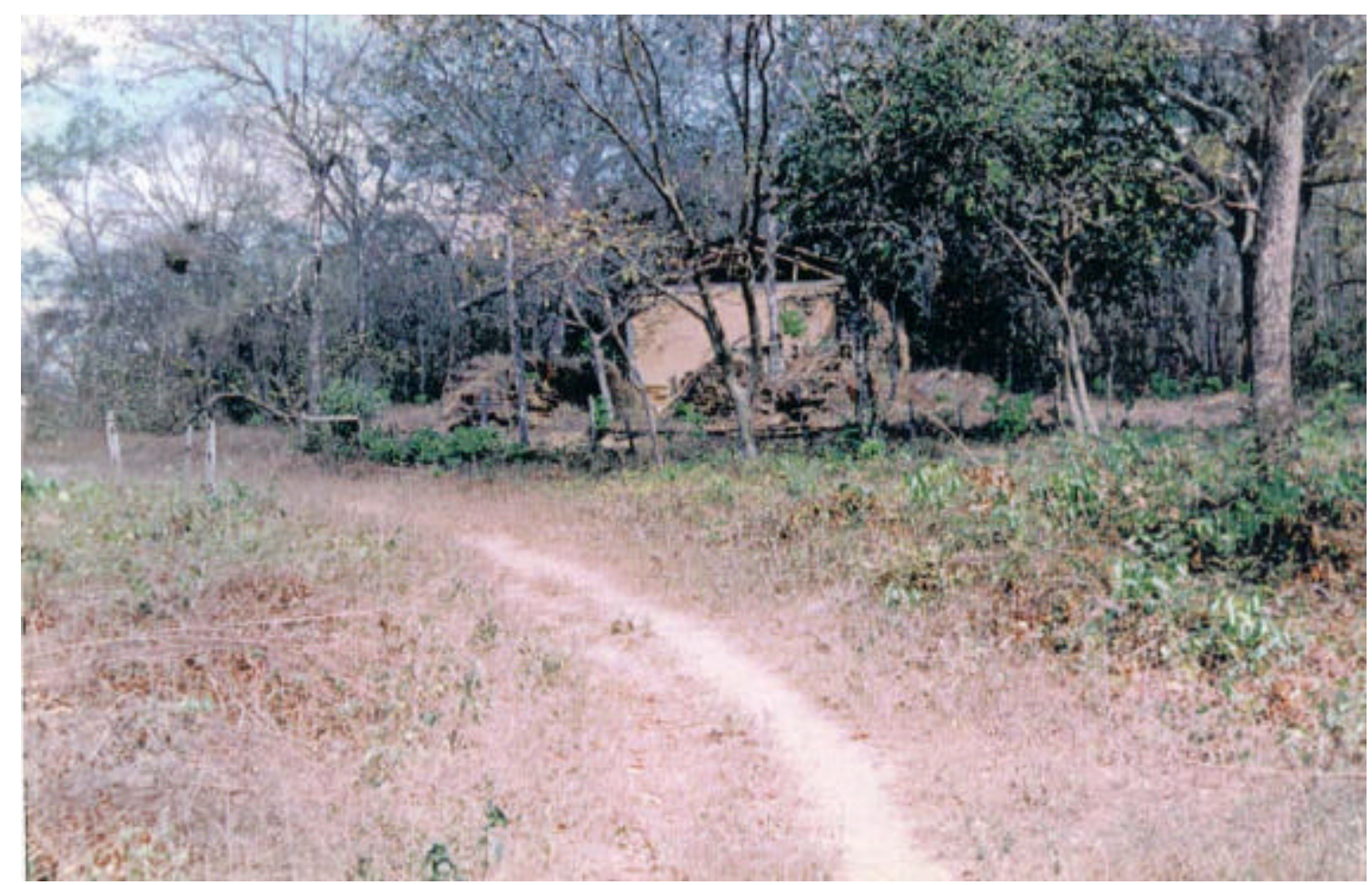

Foto 24: Vista da Capela de Santa Rita e o adro, com cemitério à frente.

(Foto: UFMG/Projeto de salvamento histórico arqueológico na área da represa de Serra da Mesa).

\footnotetext{
${ }^{213}$ POHL. Viagem no interior do Brasil. 1976, p. 177.
} 


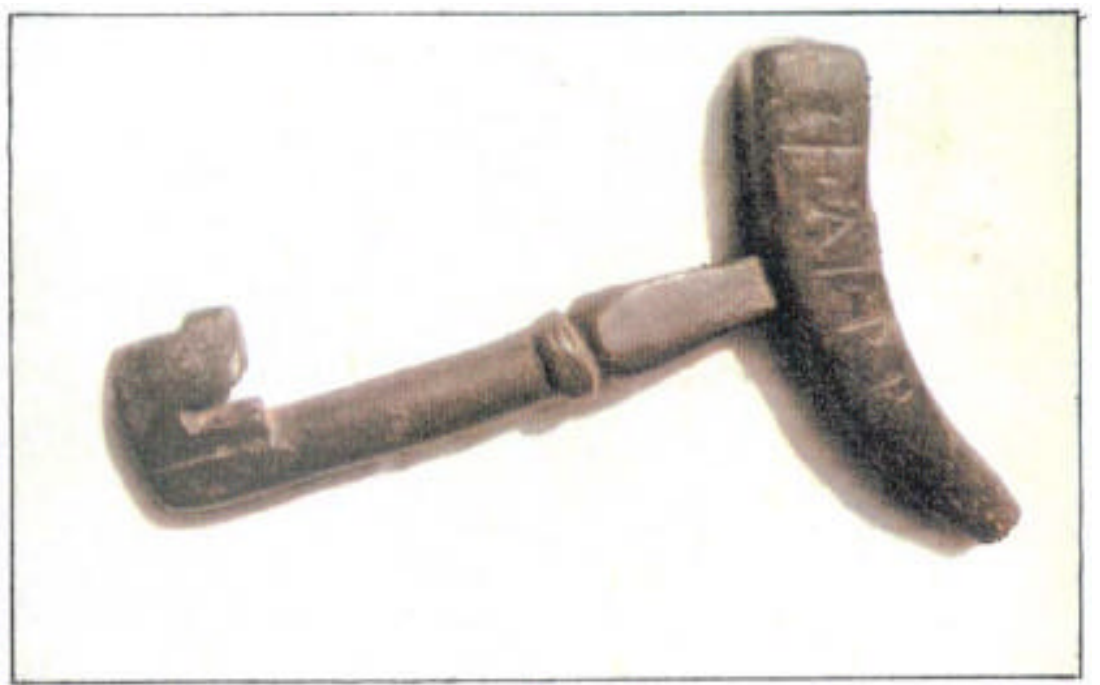

Foto 25: Detalhe da chave, ainda original, da Capela de Santa Rita.

(Foto: Furnas Centrais Elétricas S.A.)

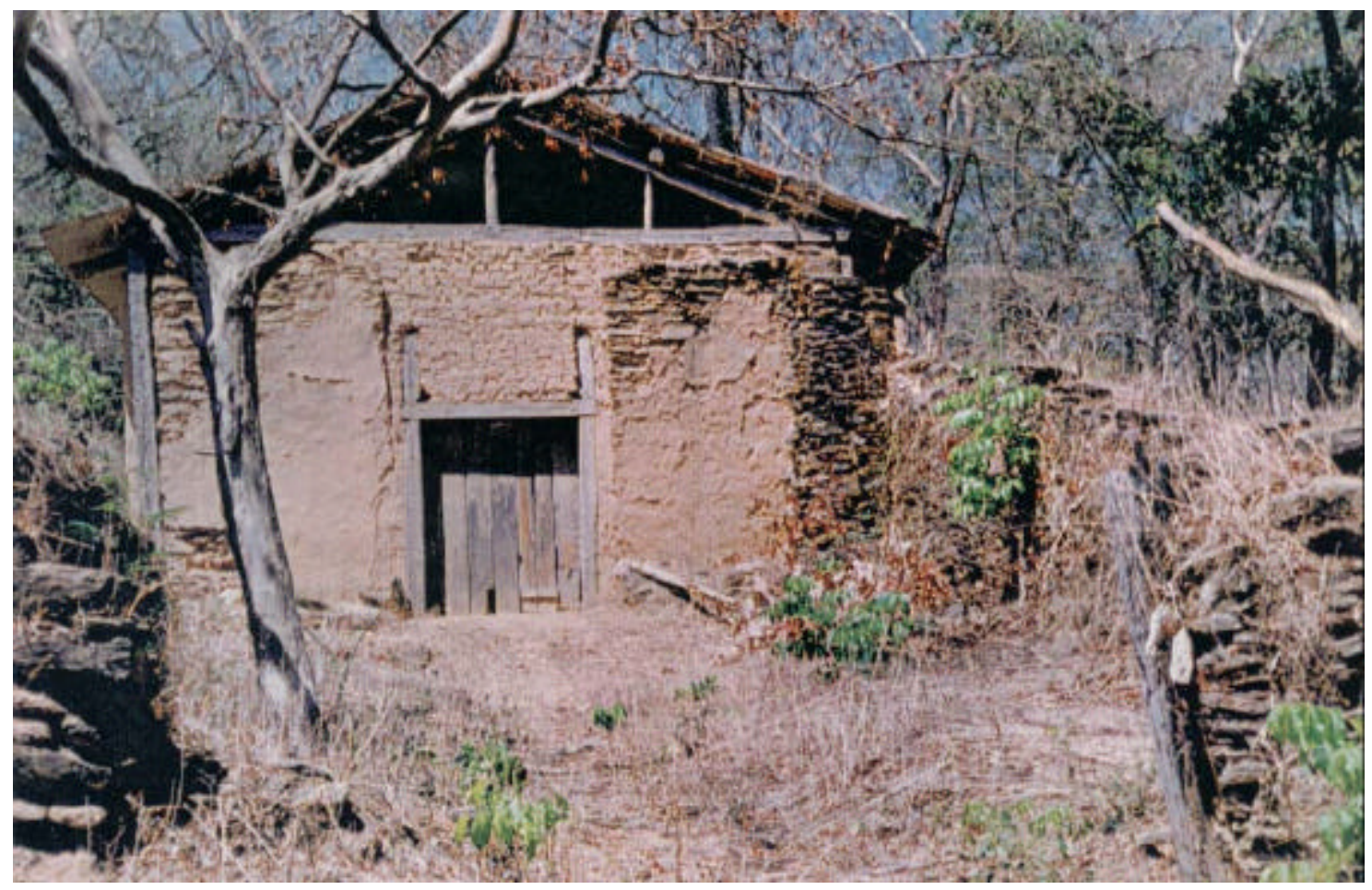

Foto 26: Detalhe do adro da Capela de Santa Rita.

(Foto: UFMG/Projeto de salvamento histórico arqueológico na área da represa de Serra da Mesa). 


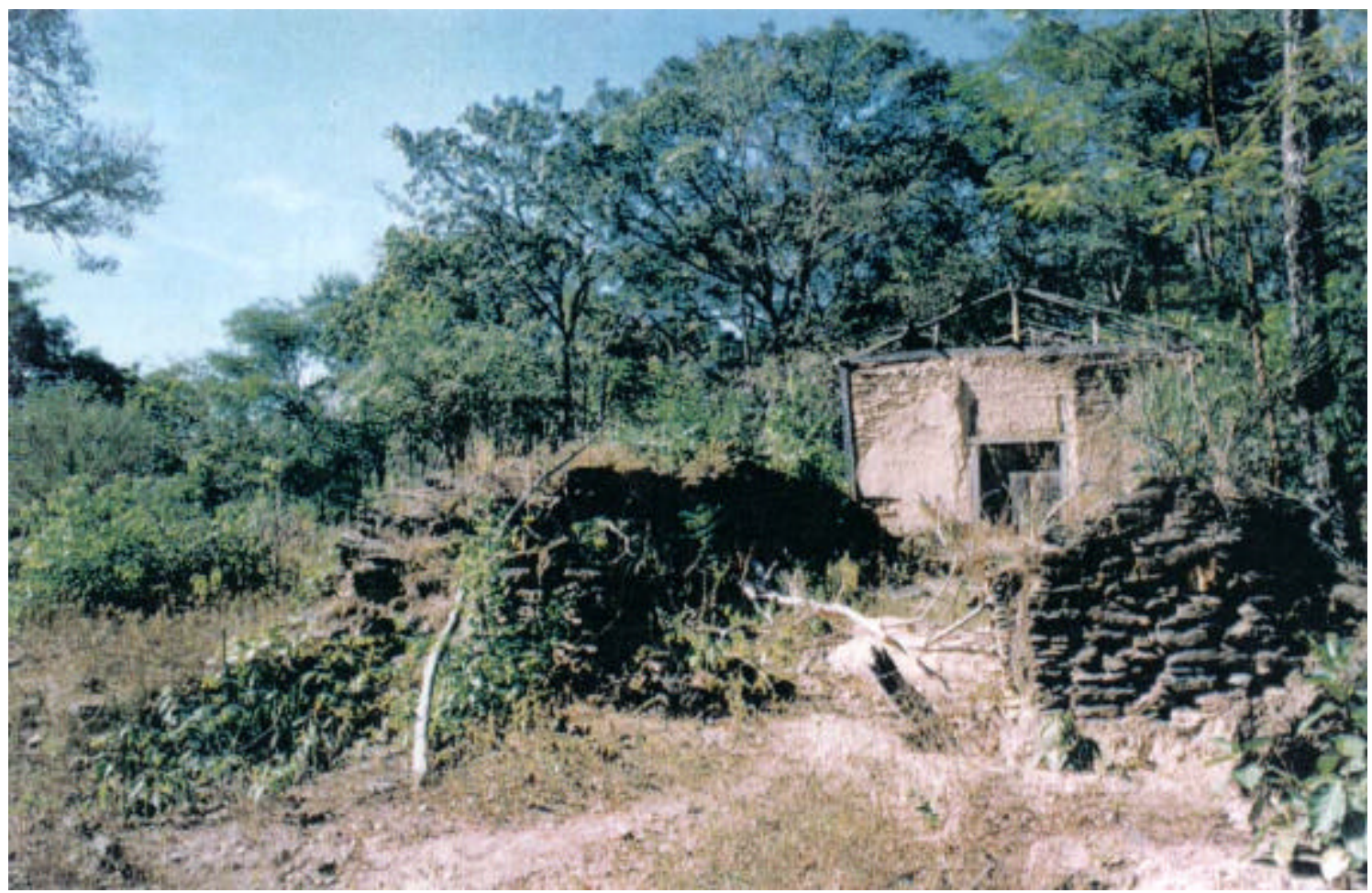

Foto 27: Vista da Capela Santa Rita e adro.

(Foto: UFMG/Projeto de salvamento histórico arqueológico na área da represa de Serra da Mesa).

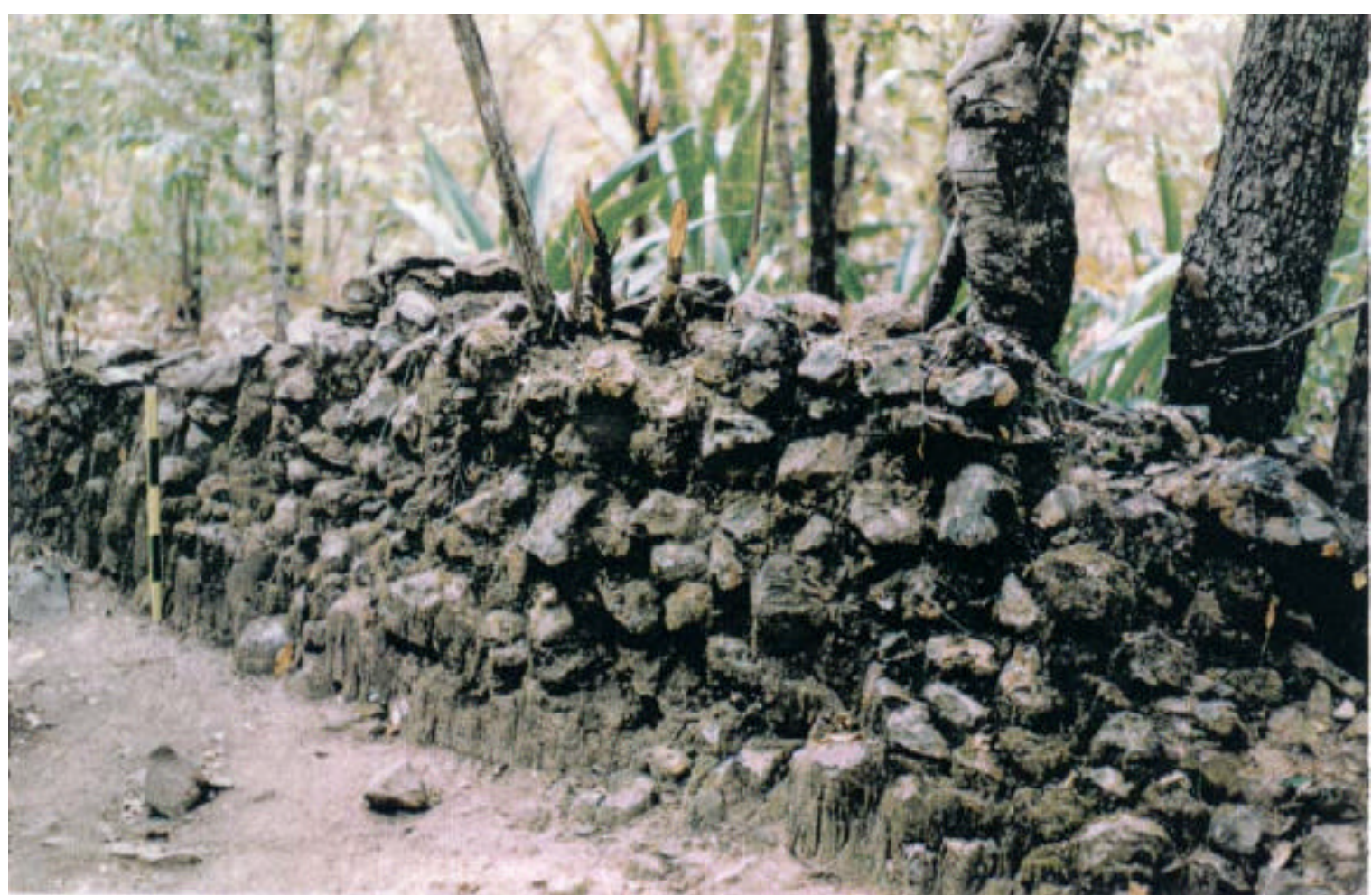

Foto 28: Estrutura de muro de pedras, Arraial de Santa Rita

(Foto: UFMG/Projeto de salvamento histórico arqueológico na área da represa de Serra da Mesa). 


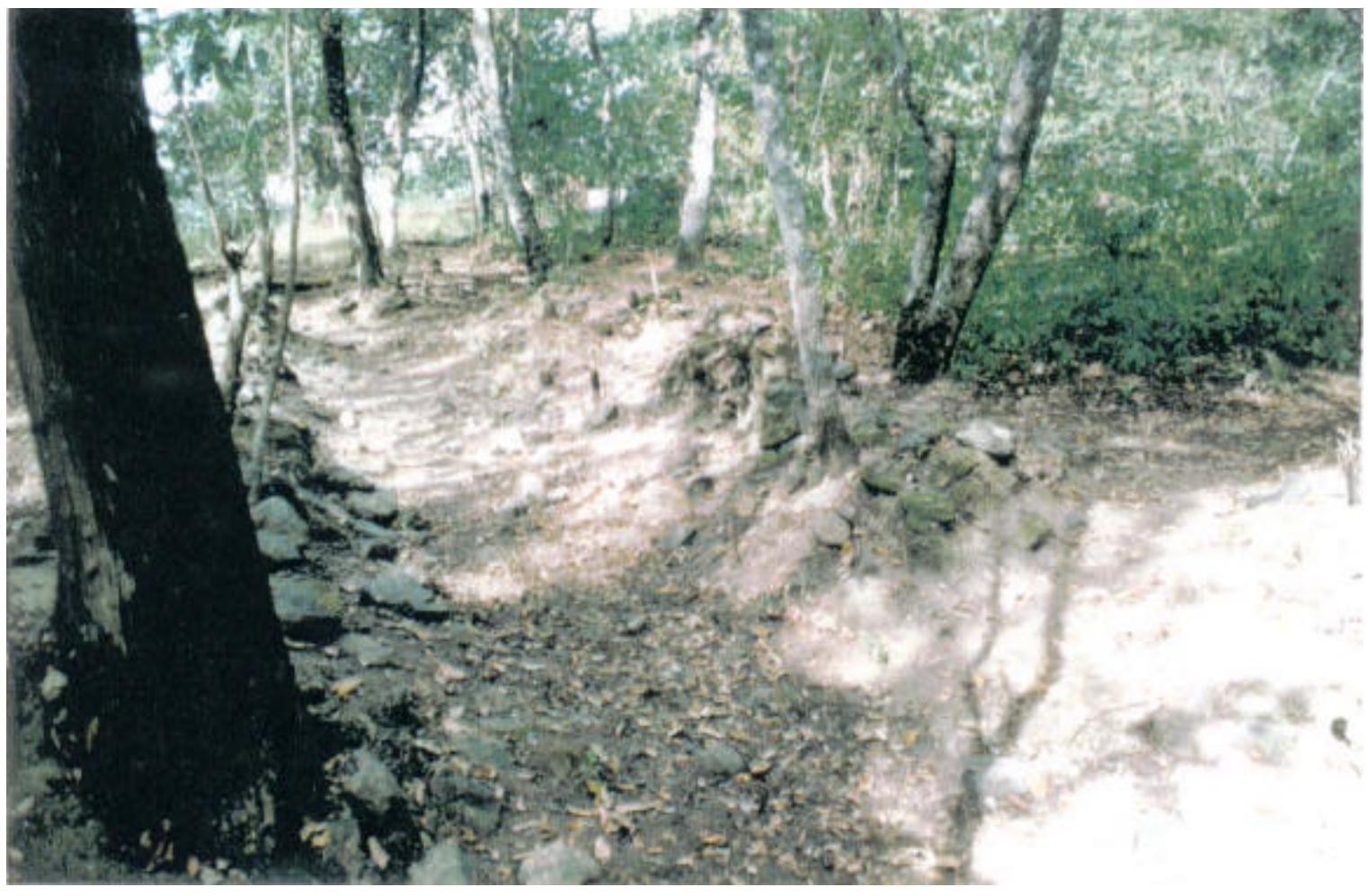

Foto 29: Vestígios de estruturas de arruamentos e muros, Arraial de Santa Rita.

(Foto: UFMG/Projeto de salvamento histórico arqueológico na área da represa de Serra da Mesa).

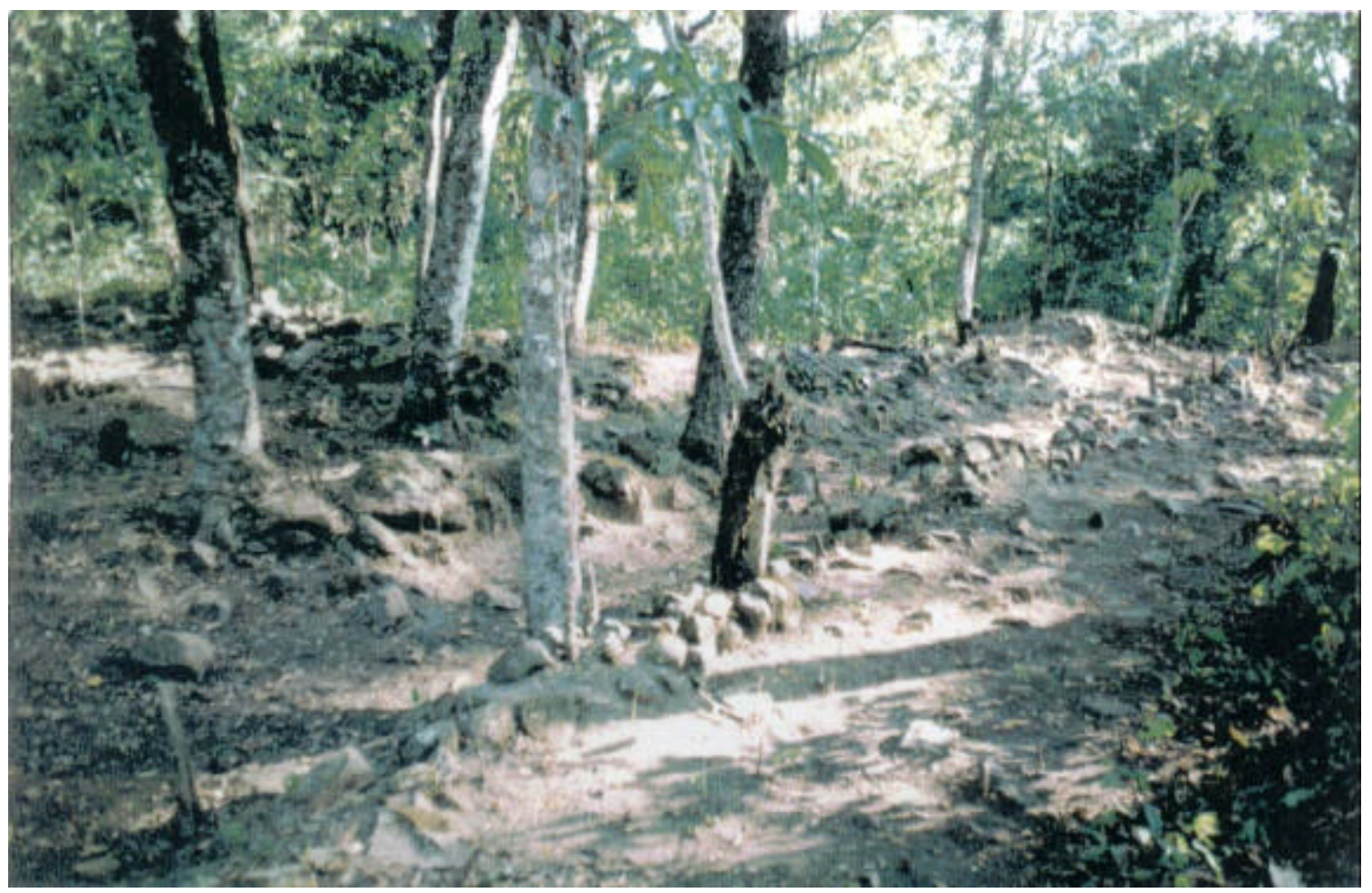

Foto 30: Vestígios de estruturas de arruamentos e muros, Arraial de Santa Rita.

(Foto: UFMG/Projeto de salvamento histórico arqueológico na área da represa de Serra da Mesa). 
Figura 05: Croquis topográfico da área do Arraial de Santa Rita

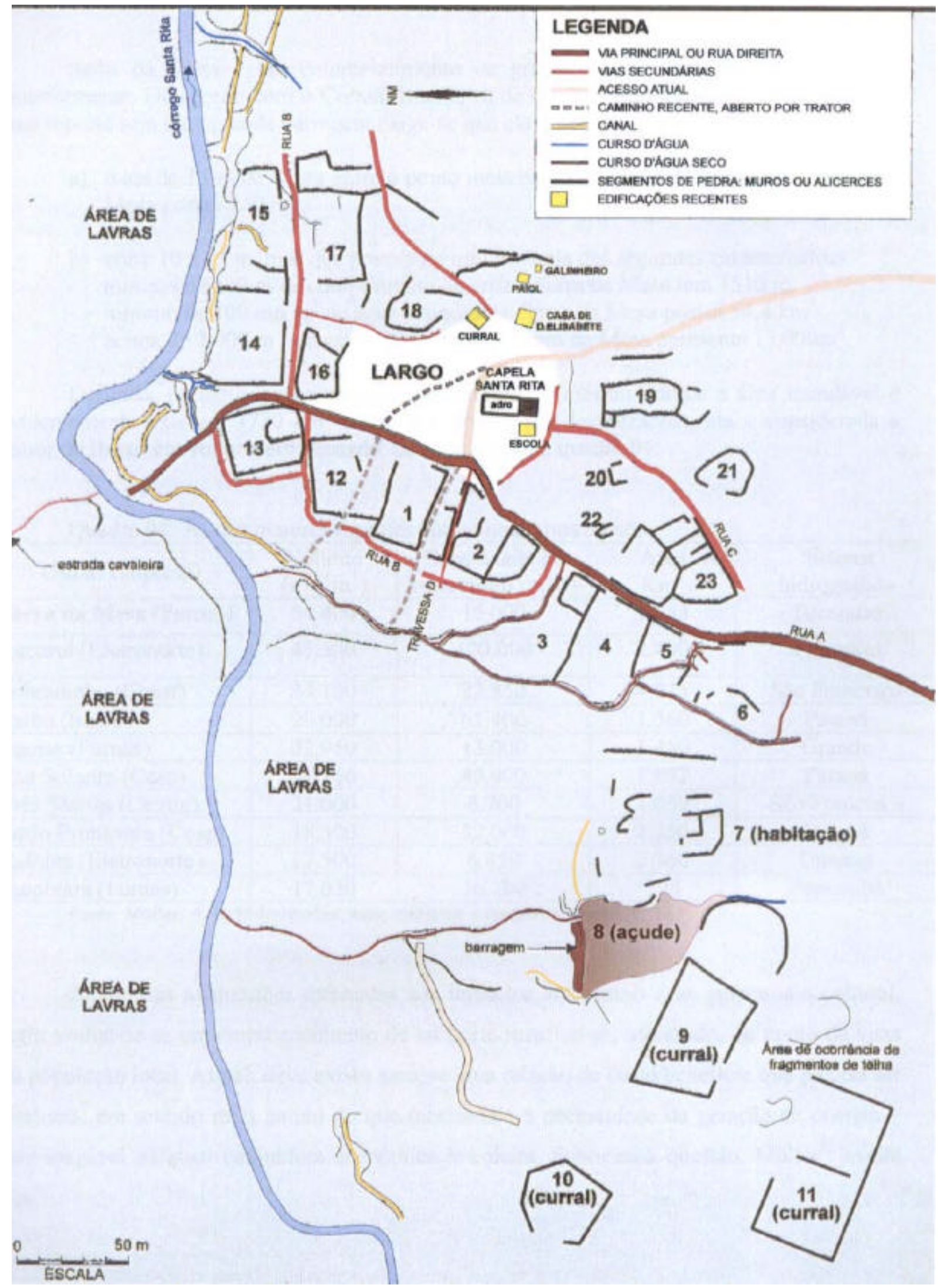

Fonte: Projeto de salvamento histórico arqueológico na área da represa de Serra da Mesa. 


\section{O empreendimento de Serra da Mesa valeu a pena? Para quem?}

Serra da Mesa é um empreendimento de grande porte, como já foi explicitado anteriormente. De acordo com o Comitê Brasileiro de Grandes Barragens (CBGB), para que uma represa seja uma grande barragem exige-se que ela tenha:

a) mais de $15 \mathrm{~m}$ de altura entre o ponto mais baixo da fundação até a crista: Serra da Mesa possui $150 \mathrm{~m}$.

b) entre 10 e $15 \mathrm{~m}$, mas que possua no mínimo uma das seguintes características:

- mínimo de $500 \mathrm{~m}$ de comprimento de crista: Serra da Mesa tem $1510 \mathrm{~m}$.

- mínimo de $100 \mathrm{mil} \mathrm{m}^{3}$ de água acumulada: Serra da Mesa possui $54,4 \mathrm{~km}^{3}$

- acima de $2.000 \mathrm{~m}^{3}$ de vazão por segundo: Serra da Mesa apresenta $15.000 \mathrm{~m}^{3}$.

Definida, portanto, como uma grande barragem, (mesmo porque a área inundável é evidentemente extensa: $1780 \mathrm{~km}^{2}$, que não devem ser desprezados), ela é considerada a maior do Brasil em volume armazenado, de acordo com o quadro 04:

Quadro 04: As dez maiores represas em volume armazenado:

\begin{tabular}{|l|c|c|c|c|}
\hline \multicolumn{1}{|c|}{ Usina (Empresa) } & $\begin{array}{c}\text { Volume } \\
\left(\mathrm{x} 10^{6} \mathrm{~m}^{3}\right)\end{array}$ & $\begin{array}{c}\text { Capacidade do } \\
\text { vertedouro }\left(\mathrm{m}^{3} / \mathrm{s}\right)\end{array}$ & $\begin{array}{c}\text { Área } \\
\mathrm{Km}^{2}\end{array}$ & $\begin{array}{c}\text { Sistema } \\
\text { hidrográfico }\end{array}$ \\
\hline Serra da Mesa (Furnas) & 54.400 & 15.000 & 1.784 & Tocantins \\
\hline Tucuruí (Eletronorte) & 45.500 & 100.000 & 2.430 & Tocantins \\
\hline Sobradinho (Chesf) & 34.100 & 22.850 & 4.214 & São Francisco \\
\hline Itaipu (Itaipu) & 29.000 & 61.400 & 1.360 & Paraná \\
\hline Furnas (Furnas) & 22.950 & 13.000 & 1.450 & Grande \\
\hline Ilha Solteira (Cesp) & 21.166 & 40.000 & 1.077 & Paraná \\
\hline Três Marias (Cemig) & 21.000 & 8.700 & 1.059 & São Francisco \\
\hline Porto Primavera (Cesp) & 18.500 & 52.000 & 2.250 & Paraná \\
\hline Balbina (Eletronorte) & 17.500 & 6.450 & 2.360 & Uatumã \\
\hline Itumbiara (Furnas) & 17.030 & 16.200 & 798 & Paranaiba \\
\hline
\end{tabular}

Fonte: Müller, A. C. Hidrelétricas, meio ambiente e desenvolvimento. P. 38

Analisadas as questões referentes aos impactos ambientais e ao patrimônio cultural, resta avaliar-se se um empreendimento de tal porte justifica-se, sobretudo, do ponto de vista da população local. Afinal, deve existir sempre uma relação de custo/benefício que precisa ser analisada em sentido mais amplo do que meramente a necessidade da geração de energia fato inegável na atual conjuntura econômica brasileira. Sobre essa questão, Müller ${ }^{214}$ avalia que

${ }^{214}$ MÚLLER. Hidrelétricas, meio ambiente e desenvolvimento, 1995, p. 103. 
"nos projetos hidrelétricos, a sociedade deve ser encarada em dois níveis. $O$ primeiro é o macro: o desenvolvimento econômico propiciado pelo suprimento da energia gerada tem alcance nacional. A sociedade aqui é difusa. $O$ outro nível é o pontual: os impactos causados pelo empreendimento gerador de energia são regionais, na área da obra, do reservatório e suas adjacências. Há portanto, um conflito potencial entre os interesses nacionais e os locais.”

Dessa forma, pode-se inferir que o que geralmente ocorre é que os interesses da comunidade externa - expressos como o interesse da nação - são sobrepostos aos interesses regionais, ou seja da comunidade local.

Assim, ainda que medidas mitigadoras dos impactos - ambientais, econômicos, sociais e culturais - que porventura venham a ocorrer sejam implementados, geralmente a satisfação da comunidade local está aquém das expectativas geradas com o empreendimento. Durante todo o período que antecede a um empreendimento desse porte, há um sem número de boatos e de manifestações que geram na população local os mais diversos sentimentos em relação ao projeto em si: geralmente coexistem o medo de se perder elementos paisagísticos e culturais que estão relacionados ao seu próprio modo e experiência de vida, com a expectativa de criação de empregos e de melhoria econômica incrementada pelas obras que advirão.

O problema maior é que as obras têm uma duração efêmera, e por mais que se arrastem, geralmente não são suficientes para dinamizar a economia local por um tempo que exceda a sua limitação. Em contrapartida, faz-se necessário, de forma incontestável, que a questão ambiental seja abordada de forma eficaz pela empresa empreendedora, de forma a posicionar, ante a opinião pública - nacional e sobretudo regional - o interesse em buscar soluções viáveis para uma situação-problema criada fora da comunidade. De maneira geral, as usinas hidrelétricas são decisões tomadas fora do contexto regional, diante da necessidade de atender-se aos interesses nacionais, manifestados nas necessidades do suprimento energético dos grandes centros consumidores.

"Naturalmente, região alguma quer sofrer impactos nos seus recursos naturais, na sua economia e no seu desenvolvimento, para produzir bens de consumo que beneficiarão somente localidades distantes. Assim, há uma crise latente entre os 
beneficiários da implantação dos empreendimentos hidrelétricos e aqueles que sofrem seus impactos. "215

Um mecanismo que começa a ser levado em consideração mais recentemente, na história do setor hidrelétrico no Brasil é a participação da sociedade, sobretudo no que diz respeito aos impactos ambientais e sociais. De fato, o país não apresenta tradição em considerar a participação da sociedade nas questões ligadas ao planejamento e desenvolvimento. Isto ocorre particularmente no setor elétrico, por se tratar de área de prioridade, visto que estava diretamente vinculado à possibilidade de desenvolvimento econômico; afinal, sem energia, não há industrialização.

"As circunstâncias que destacaram esse setor da vida nacional como prioritário, durante vários governos, geraram seu relativo isolamento frente a outras áreas da administração pública, que lhe atribuíam uma imagem de prepotência, de auto estima exacerbada. Se há alguma razão nessa crítica, pode ser porque, ao ser considerado como essencial ao desenvolvimento nacional, atribuiu-se ao setor sobrecarga de importância e prioridade, o que o distanciou de outros setores, na época não tão privilegiados, por exemplo, com dotações orçamentárias. (...) A política de desenvolvimento adotada na década de 1960 era baseada na industrialização nacional e os setores que davam suporte àquela política, como os de comunicações, transporte e energia, avançaram mais que outras áreas da vida nacional." 216

Essa situação, em que da importância do setor elétrico era destacada como sendo elemento primordial ao desenvolvimento do país - à partir da idéia, errônea, de que desenvolvimento e industrialização são sinônimos - perdurou também durante toda a década de 70, sob o regime autoritário que se instalou. “(...) as reações da sociedade eram consideradas, via de regra, como oposição de caráter político, portanto, alvo de repressões. As comunidades afetadas pelos 'projetos de desenvolvimento' deveriam aceitá-lo, ainda à sua custa, sem estruturar qualquer reação."217 A partir do final da década de 70 e durante toda a década de 80 , com o avanço do processo de abertura política, e considerando-se inúmeras

\footnotetext{
${ }^{215}$ MÚLLER. Hidrelétricas, meio ambiente e desenvolvimento, 1995, p. 100.

${ }^{216}$ MÜLLER. Hidrelétricas, meio ambiente e desenvolvimento, 1995, p. 101.

${ }^{217}$ MÚLLER. Hidrelétricas, meio ambiente e desenvolvimento, 1995, p. 101.
} 
experiências negativas ${ }^{218}$, onde os impactos sociais e ambientais eram de fato marcantes, foi se dando de forma lenta e gradativa a inserção dos interesses das populações afetadas dentro dos projetos de construção de barragens para geração de energia elétrica.

Foram de grande importância para a consideração dos fatores ambientais os problemas enfrentados junto ao Banco Mundial, sendo necessário que o setor elétrico revisse todas as suas premissas de solução para os problemas ambientais para poder continuar contando com a liberação de empréstimos daquela instituição. Data dessa época a elaboração da nova Constituição do Brasil, que prevê a elaboração de estudos de impactos ambientais para toda grande obra realizada, a partir de então, no país.

Dessa forma, Serra da Mesa surge no cenário nacional num momento político de importantes mudanças, mas, devido ao fato de ter sido implantada no limiar dessas mudanças, ela não se beneficia completamente de todas as possibilidades que se abriram. De fato, as perspectivas eram boas, mas as ações que se concretizaram tinham o cunho muito mais paliativo do que preventivo. Na realidade, Serra da Mesa cumpriu bem o seu papel dentro das perspectivas institucionais, mas para a população local, todas as medidas foram tomadas dentro dos gabinetes oficiais, sem a sua efetiva participação. Se a obra tivesse sido planejada alguns anos mais tarde, poderia ter havido tempo para se implantarem todas as políticas mitigadoras de impactos socio-ambientais, com maior participação popular, o que de fato não ocorreu.

Não se pode negar, contudo, que o empreendimento trouxe benefícios para a região onde está inserido. O estudo do acervo cultural histórico e pré-histórico regional é uma prova concreta disso. Dificilmente, em outras circunstâncias, teria sido possível empreender um trabalho tão grandioso do ponto de vista da abrangência espacial e do ponto de vista contextual. A análise da ocupação e do povoamento de Goiás, a coleta de dados e de cultura material e a perspectiva de se reinserir junto à população local os vestígios ali encontrados não teria sido possível sem o apoio financeiro de FURNAS.

A busca do conhecimento do patrimônio da área de Serra da Mesa vai além das perspectivas elementares. A UHE permitiu o conhecimento e a análise da região em todos os

\footnotetext{
${ }^{218}$ Críticas contundentes foram feitas diante dos problemas socio-ambientais em obras como Itaparica, Machadinho e Balbina.
} 
níveis de interesse: a fauna, a flora, a geomorfologia, a história e a pré-história, além do aspecto indígena. Mas a grande questão é saber se esse conhecimento sobre uma área que não existe mais é justificável. Afinal, nem mesmo a reserva indígena foi preservada. A questão cultural foi tratada de forma detalhada do ponto de vista material, mas quanto ao social sempre deixa a desejar. As relações das famílias com o meio ambiente e com a paisagem são bens que não se pode mensurar do ponto de vista econômico.

Um patrimônio cultural não pode ser vendido ou comprado, mesmo que as indenizações sejam generosas. A perspectiva do Estado sobre a questão é, em geral, diametralmente oposta à da população local. De acordo com Lopes ${ }^{219}$,

“a um conceito amplo de cultura corresponderá, necessariamente, um patrimônio cultural de proporções gigantescas e a necessidade de uma política de eficiência ímpar. Surgem as dificuldades: a execução está sempre com anos de atraso em relação à formulação. Sobretudo, incapaz de acompanhar de fato o eterno modelo moderno-democrático sugerido nos conceitos emitidos, o Estado não poderia se permitir compromissos exemplares nas experiências com a alma do povo, financiadas pelo próprio povo."

De qualquer forma, há que se compreender que empreender políticas visando à valorização do patrimônio cultural de uma nação é dever do Estado, sobretudo quando os problemas sociais são de tal vulto que ponham em segundo plano a questão da cultura. A capacidade de valorização de um mesmo patrimônio pode, no entanto, ser diferenciada, de acordo com a perspectiva que se lhe impõe. Choay ${ }^{220}$ faz uma análise abrangente da questão do patrimônio, e com relação à França pós revolução, descreve alguns tipos de valores que podem ser definidos em relação ao patrimônio. Guardadas as devidas proporções, mesmo porque a autora analisa mais especificamente os monumentos, pode-se destacar de seu estudo alguns parâmetros de valorização, tais como:

- o valor nacional: quando há interesse do estado em um determinado bem histórico, gerando assim interesse em se criar mecanismos que garantam a sua proteção.

\footnotetext{
${ }^{219}$ LOPES. A propósito de política cultural, Revista do Patrimônio Histórico e Artístico, n. 22, 1987, p.26.

${ }^{220}$ CHOAY. A alegoria do patrimônio, 2001, p.117.
} 
- o valor cognitivo: trata-se de um termo mais amplo, englobando aí "uma série de ramos relativos aos conhecimentos abstratos e às múltiplas competências. (...) são testemunhas irrepreensíveis da história."

- o valor econômico: quando os monumentos são capazes de atrair turistas, tornando-se assim uma atividade econômica atraente.

- O valor artístico: não por acaso aparece em último lugar, sendo restrito a um número reduzido de pessoas, já que o próprio conceito de arte ainda não se popularizou.

A partir dessa categorização, pode-se inferir que a própria noção de patrimônio pode tornar-se mais difusa, e que ao Estado, a quem cabe lidar com a sua definição e preservação, a tarefa não se torna tão simples. Uma das maiores dificuldades enfrentadas nesse processo é que no Brasil não existe tradição de valorização de bens nacionais. Somente muito recentemente este quadro vem, aos poucos, modificando-se.

Diante das circunstâncias, é que se acredita que a situação criada em Serra da Mesa acaba tornando-se altamente positiva. A despeito do grande impacto ambiental que uma obra desse porte traz consigo, pelo menos pode-se salientar como ponto positivo que muito se revelou aos olhos da comunidade acadêmica sobre uma região da qual muito pouco se conhecia. Ocorre que, a partir da análise desse material, é imprescindível que todo esse conhecimento retorne à sua comunidade de origem, respaldando diante da população local todo o investimento que foi empreendido nesse processo de salvamento.

Acredita-se que a UHE de Serra da Mesa era um empreendimento considerado definitivo dentro dos interesses econômicos do país e, portanto, o andamento de suas obras era de caráter irreversível, mesmo porque muito dinheiro já havia sido investido na primeira etapa do projeto. Dessa forma, diante do quadro que se delineou, não havendo alternativas que inviabilizassem os impactos ambientais, o que se buscou foi minimizar os impactos sociais, através dos diversos programas já analisados, dentre eles o de resgate e salvamento do patrimônio cultural. Pode-se assim compreender a importância dos estudos aí realizados, uma vez que, de qualquer forma, esse patrimônio estaria definitivamente perdido, caso as obras chegassem ao seu término, sem a sua concretização. 
De acordo com a categorização de Choay, apresentada acima, a valorização do patrimônio no caso de Serra da Mesa começou no nível nacional, em que o interesse do seu resgate partiu primeiro do poder público. Evidentemente as condições políticas e econômicas do país contribuíram para isso. Sem a efetivação de um programa bem estruturado visando a proteger os interesses das comunidades locais do ponto de vista da cultura e do meio ambiente, os financiamentos para o andamento das obras teriam sido dificultados. Ainda assim pode-se considerar como sendo positivo esse interesse, já que uma análise de grande abrangência como a que foi realizada dificilmente o seria, se não partisse do Estado, mesmo porque os custos do financiamento de um projeto como esse seria motivo suficiente para inviabilizá-lo em outras instâncias. O próprio valor econômico dos bens resgatados, não seriam atraentes para a iniciativa privada. Não existe expressividade monumental nos bens resgatados a ponto de gerar o interesse pela sua exploração turística. No futuro, se todos esses bens forem reunidos, sob o teto de um museu, por exemplo, com uma boa infra-estrutura e com um bom trabalho de divulgação - mantendo-se a fidelidade histórica - há evidentemente a possibilidade de, junto com as belezas naturais da região, vir a tornar-se um fator de atração para visitantes e turistas.

A expectativa local, durante o período de construção da UHE, era de que com a sua conclusão, o abastecimento de energia seria regularizado (até então era extremamente precário) e que haveria excedente suficiente para dinamizar a economia local, incrementando inclusive o setor industrial nos municípios mais populosos. O que não se levava em consideração, à época, talvez até por desconhecimento, é que uma unidade produtora da envergadura de Serra da Mesa não tinha como objetivo primordial produzir energia elétrica para a região, cuja demanda ainda é bem pequena. $\mathrm{Na}$ realidade, o empreendimento só se justificava em função da necessidade de se produzir energia para suprir a demanda da região centro-sul do país, como aliás veio a se confirmar, diante do quadro caótico que se acentuou recentemente com a grave crise energética que tomou proporções assustadoras.

Há no entanto, a possibilidade de um retorno econômico para a região, desde que o Estado continue investindo localmente, tornando viável a continuidade do projeto de valorização do patrimônio cultural, e sobretudo, se for possível, manter-se a mesma qualidade com que ele foi desenvolvido até então. A associação do binômio recursos naturais e patrimônio cultural pode ser a chave para a dinamização da economia local, e, a partir daí, desenvolver outros setores importantes, como saneamento básico, educação e educação 
ambiental, saúde, infra-estrutura viária, entre outros, garantindo-se, assim, possibilidade de melhoria nas condições de vida da população como um todo, mesmo porque essa população necessita de um retorno positivo, já que arcou com os custos negativos do empreendimento. Além disso, de acordo com Müller, “a avaliação e solução dos efeitos socioambientais de um empreendimento hidrelétrico precedem a obra, são realizadas durante a construção e continuam na operação" 221 - ou seja, o fato de as obras de construção da unidade produtora terem chegado a termo não é motivo para que o poder público se isente das responsabilidades nem das consequiências que porventura possam vir a surgir.

Diante da nova realidade brasileira, e no contexto geopolítico atual, também o setor elétrico precisa reorganizar-se, sobretudo na busca de novos caminhos no relacionamento com a sociedade, para que seja possível, assim, viabilizar novos projetos necessários ao desenvolvimento econômico nacional, diante da constatação de que o desenvolvimento econômico é o primeiro passo, mas não se constitui no único caminho para uma sociedade mais justa. O desenvolvimento social e o cultural precisam estar lado a lado, e serem igualmente enfatizados. É por isso que o setor elétrico tem buscado inovar, através de um engajamento maior com a sociedade com a qual trabalha, procurando aliar e conciliar interesses como meta de trabalho.

Um dos passos mais importantes nessa caminhada é a valorização e o resgate da cultura, principalmente através da valorização do patrimônio cultural das comunidades locais. Considerando-se que a realidade de cada uma é única, e como tal, é também complexa e dinâmica; e que os aspectos culturais se diferenciam tanto no espaço quanto no tempo, é que se torna imprescindível conhecer, reconhecer e resgatar todos os testemunhos dessas diferentes manifestações. Daí a grande importância de Serra da Mesa: através dela, conhecese hoje um pouco mais de uma história e de uma paisagem praticamente desconhecidas pelo resto do Brasil. Parafraseando Guimarães Rosa, podemos dizer também que o Brasil são muitos...

${ }^{221}$ MÜLLER. Hidrelétricas, meio ambiente e desenvolvimento, 1995, p. 111. 
CONSIDERAÇÕES FINAIS

"Resultam ainda frágeis os indicadores de nossa identidade cultural ..."

Aloísio Magalhães. 


\section{Considerações Finais}

O Brasil é um país singular: ainda que grandioso em aspectos naturais e culturais; pouco se conhecem, e conseqüentemente, pouco se valorizam essas riquezas. Desde o período colonial, nitidamente marcado pela expropriação, tem-se convivido com um tipo de aculturamento que mantém o país na condição de fornecedor, com grande potencial de desenvolvimento sempre voltado para o futuro; no entanto, este futuro nunca se aproxima, e portanto, tal potencial não se realiza.

Não há dúvida de que esta situação se perpetua também por uma série de outras contingências que escapam ao nosso controle, como a posição do país no cenário econômico mundial, o seu papel dentro da divisão internacional do trabalho e as características da expansão capitalista, sobretudo no atual processo de globalização.

“(...) o modo de produção atual está voltado mais para uma revolução científica e técnica e não social e política, com um sistema mundial de Estados, uma urbanização maciça, divisão mundial do trabalho e portanto a cotidianidade."222

\footnotetext{
${ }^{222}$ LEVEBVRE, citado por BERTOLOZZI \& PEREZ FILHO. Crise Ambiental da modernidade e a produção
} do espaço-lugar do não cidadão. In: Boletim Paulista de Geografia, n.76, 1999, p.11. 
No entanto, há que se considerar que a forma de ocupação e expansão do território nacional facilitou esse encaminhamento dos fatos. Analisando a ocupação européia no Brasil, Morley $^{223}$ coloca que:

“ estabelece-se o português no Brasil com objetivos traçados no Reino e com modelos de apropriação inspirados em conquistas anteriores. (...). Desse sertão pouco se sabe; exceto as incursões específicas terra adentro para prear índios ou buscar as minas, o português restringe-se à vida das cidades (...). a luta pela sobrevivência e a ambição da riqueza levam ao desprezo pelos pequenos detalhes que são deixados para trás à medida que o colonizador avança. (...) Inaugura-se assim a melancólica trajetória de um povo que não teve por hábito ocupar-se do registro de seus costumes, rejeitando o passado mesmo mais recente em favor das inovações."

Essa atitude passa a fazer parte da cultura nacional. Não se estabeleceu no Brasil o hábito de preservar nem de valorizar o passado. Muito se tem perdido em termos de patrimônio cultural no país, tratado com descaso pelas autoridades e com desinteresse pela população. Só muito recentemente esse quadro vem sofrendo pequenas alterações. A partir do momento em que a legislação brasileira tem-se aprimorado para regulamentar ações sobre o patrimônio cultural, é que tem surgido novas perspectivas nesse cenário. No entanto, essa legislação, embora bastante ampla e de boa qualidade, ainda não se efetiva na prática da forma como se faz necessário, e, até que isso ocorra, ainda será comum a perda de elementos culturais praticados em função dessa ineficiência legislativa.

"É certo que a história da cultura de uma sociedade está, naturalmente, relacionada de modo direto à preservação de sua memória. No entanto, este cuidado tem variado de povo para povo, de acordo com a importância que cada qual confere às suas próprias expressões, ou por outro lado, dependendo dos fatores externos que levam à conservação de determinados valores em detrimento de outros. Em ambos os casos podemos situar os povos que foram objeto de colonização por parte de nações ditas 'mais civilizadas', e que por força da dominação contribuíram para a anulação das manifestações indígenas. Como conseqüência inevitável, dá-se a perda gradual dos costumes que são substituídos por modelos importados, até que permanecem apenas como sobrevivências

${ }^{223}$ MORLEY. Fazer arqueologia: resgatar memórias, Revista do Patrimônio Histórico e Artístico Nacional, $\mathrm{n}^{\circ}$ 22, 1987, p. 212. 
ou como um pano de fundo, dificilmente percebido em um exame superficial."224

A partir de então, pode concluir-se que faz-se necessário e urgente o resgate dessa memória cultural, através de trabalhos e de pesquisas que incluam a análise das sociedades primitivas e/ou de aspectos culturais em risco de se perderem. A arqueologia histórica faz bem esse papel, contando, para isso, com o suporte de várias outras ciências, dentre elas, a Geografia. De maneira geral, pode-se dizer que empreender uma pesquisa de tal envergadura, como a realizada em Serra da Mesa, não é tarefa simples, e só pode lograr êxito se for conduzida através de uma análise multidisciplinar. Neste caso, a equipe de pesquisadores precisa ser composta por profissionais de diferentes áreas, cuja contribuição particular vá-se somar ao todo, constituindo assim um grupo em sintonia com o mesmo ideal: somar esforços para se alcançar o objetivo pré-determinado.

Dentro de uma análise desse tipo, em que há, nitidamente, uma abrangência espacial e temporal, há que se buscar conhecer as condições históricas e sociais da comunidade ou do período em questão. $\mathrm{Na}$ área de Serra da Mesa, observou-se que as condições geográficas foram determinantes ao influenciar a ocupação da região de forma direta. Neste caso, o estudo demanda um enfoque espacial concomitante, e por isso, o nosso papel como profissional da Geografia foi de importância fundamental. O geógrafo é, sem dúvida, o profissional mais indicado para auxiliar aos demais profissionais de outras áreas a perceberem os elementos geográficos e paisagísticos como sendo constituidores dos sítios arqueológicos demandados.

Em Serra da Mesa, cada equipe de trabalho esteve composta por um grupo bastante heterogêneo de pesquisadores. No entanto, teve-se o cuidado de se garantir, sempre, a presença de um profissional da Geografia em campo. Ao geógrafo destacava-se um papel de suma importância e de ordem prática, por se tratar de uma área não-urbana, muito ampla e, na época, desconhecida das pessoas envolvidas no trabalho. Dessa forma, o próprio deslocamento na região constituía-se numa dificuldade para o trabalho. Os mapas disponíveis para a região não eram recentes - datavam do fina da década de 70 - e já estavam bastante desatualizados, sobretudo no tocante à malha viária. Além disso, a escala desses mapas não

\footnotetext{
${ }^{224}$ MORLEY. Fazer arquelologia: resgatar memórias, Revista do Patrimônio Histórico e Artístico Nacional, n.22, 1987, p. 213.
} 
era a ideal, eram cartas topográficas elaboradas na escala 1:100.000, o que não nos permitia uma visão muito detalhada da área.

Dessa forma, coube a nós, geógrafos, auxiliar no procedimento da leitura desses mapas, determinar rotas a serem seguidas pelos grupos de pesquisa, identificar elementos geográficos na paisagem e localizá-los no mapa, e, por fim, contribuir na orientação dos demais pesquisadores quanto à sua localização e à localização dos vestígios buscados com a utilização do equipamento de GPS.

Outra contribuição geográfica fundamental para a pesquisa referiu-se ao auxílio na determinação da real posição dos vestígios buscados quanto à altimetria. Esse era um dado fundamental para os pesquisadores, pois só a partir dessa informação é que se poderia definir se um determinado vestígio constituiria-se ou não em objeto de salvamento, já que apenas os vestígios abaixo da cota de inundação, ou seja, abaixo de $460 \mathrm{~m}$, estavam correndo risco; sendo assim, necessariamente considerado como objeto de salvamento. A partir de então, e ao longo de todo o trabalho foi-se tornando possível compreender as relações espaciais entre as ocorrências arqueológicas e as paisagens regionais.

Diante da análise dos sítios arqueológicos e da sua inserção espacial, foi-se ficando claro que não seria prudente considerar como sendo suficiente a investigação dos artefatos em si mesmos. Embora eles possam ser encarados como a tradução das tendências da sociedade em uma determinada época, podia-se inferir, a priori, que a sua situação espacial poderia ser determinante para indicar onde ocorreriam tais tendências, confirmando ou negando a hipótese sobre a ocupação da região. Em Serra da Mesa, os artefatos (ou exemplares de cultura material) encontrados confirmaram de forma inequívoca as áreas de ocupação da mineração e as áreas de ocupação das fazendas. Nos locais em que as duas atividades foram contemporâneas é que se encontrou vestígios de ambas, sendo que a mineração é a atividade que mais interfere, de forma marcante, na paisagem. Além disso, há que se compreender que, de maneira geral, a ocupação através da atividade agropecuária poderia ter ocorrido em qualquer área da região, ao passo que, a ocupação, através da mineração, só poderia ter acontecido, como de fato se deu, em áreas onde havia a ocorrência de metais e/ou pedras preciosas (sobretudo o ouro). 
Podemos concluir portanto, que ao geógrafo deverá ser sempre garantido um espaço dentro dessas equipes e que a interdisciplinaridade será sempre o melhor caminho para análises tão abrangentes. A contribuição aí de outros pesquisadores é fundamental, como, por exemplo, o historiador, buscando contextualizar os elementos analisados; o arquiteto, que fará a avaliação dos vestígios arquitetônicos; o especialista avaliando a conservação, e outros.

A própria convivência com profissionais de diferentes áreas, por si só, constituiu-se em uma experiência altamente enriquecedora para a experiência profissional de cada um dos envolvidos, sobretudo da autora deste trabalho.

No entanto, para nós, a percepção da importância da análise geográfica é que realmente tornou a experiência dessa pesquisa fascinante. Observar a relação direta entre sítio, paisagem e vestígios arqueológicos constituiu-se em uma constatação inequívoca, demonstrando como elementos paisagísticos e geográficos interferiram na ocupação direta daquela região.

Em todos os casos, os vestígios que se definiram e interferiram na paisagem - sejam como sítios de mineração, de fazendas, mistos ou vestígios de cidades - constituem-se em verdadeiras "paisagens históricas", pois foram agregando, ao longo dos tempos, valores simbólicos relevantes para a consciência coletiva regional (e talvez até nacional), e como tal precisam ser encaradas pela legislação e pelos órgãos responsáveis pela preservação.

Mas, e a paisagem que se perdeu? Como encarar a destruição de um patrimônio, carregado de valores e de história? Os artefatos podem ser resgatados e preservados em um museu, por exemplo, mas com paisagens o tratamento é diferenciado. A perda de um patrimônio paisagístico é definitiva.

Cabe então, a partir desse momento, uma preocupação maior com relação à paisagem. Além do caráter histórico, faz-se necessário destacar que as paisagens são construídas ao longo do tempo e a partir das vivências das pessoas com o seu meio. São, portanto, o resultado de uma convivência que pode ter-se estabelecido durante toda uma vida. São também o testemunho da globalidade de uma época, sendo portanto muito mais do que o resultado da soma de fatos que se sucederam cronologicamente. Constitem-se assim, 
elementos tão importantes dentro do contexto histórico quanto qualquer outro testemunho, e, dessa forma, devem ser preservados tanto quanto seja possível; já que apresentam uma característica inegável: a mutabilidade. Nenhuma paisagem está pronta e acabada, toda ela é passível de sofrer modificações no decorrer do tempo. Mesmo porque, se ela é definida como sendo o resultado das ações humanas ao longo do tempo, ela é, necessariamente, dinâmica.

Mas o seu dinamismo não implica, necessariamente, destruição. Pode-se mudar, suceder fatos, remodelar a paisagem e o entorno de um ambiente sem que se desfaça do anterior, sobretudo se as novas manifestações puderem ser acrescidas às primeiras. Mas o que ocorre em Serra da Mesa é que as diversas paisagens locais, carregadas de contexto histórico e geográfico foram substituídas por uma única e grande paisagem: a do lago da represa, cujo objetivo final é garantir a produção energética nos níveis em que foi planejado. E, assim, a paisagem que foi substituída e que era também um patrimônio cultural não pôde ser deslocada como os demais artefatos.

Pode-se dizer então que, em termos paisagísticos, a região ficou empobrecida, ou talvez deficitária? Acredita-se que não necessariamente. $O$ fato é que houve uma redução na quantidade de cenários, sendo que muitos, belos e raros, acabaram por se perder de forma definitiva. No entanto, uma nova e ampla paisagem surge, imponente e grandiosa. Mas esta nova paisagem requer vivências. Não existe ainda entre a população local e a represa de Serra da Mesa nenhuma história construída, pois trata-se de uma paisagem completamente nova. Tudo o que ela vier a representar na vida dessa população, terá que ser ainda construído, ao longo do tempo.

Mas, o que importa, acima de tudo, é que, o que se construir de novo, a partir desse momento, não deve ser construído em detrimento de toda história que já existiu e que já foi vivida. Por isso torna-se tão importante manter-se viva a memória da cultura, das paisagens, do período histórico passado e erguido nessa região. Daí a grande importância de um projeto de salvamento como o empreendido na área. Não se pode construir o futuro sem valorizar o passado. Se a modernidade exigiu a destruição de parte do patrimônio cultural regional, então, a partir daí, tudo o que se construa seja com vistas a resgatar a memória e a cultura desse povo. Valorizar a cultura local, resgatar valores, edificar a cidadania e recompor a auto-estima da comunidade, tanto quanto possível, com base na conscientização de sua própria história e 
cultura; buscar encarar a nova realidade com o máximo de compreensão, a despeito da crise econômica, política, social ou cultural.

"É imprescindível buscar um modelo de civilidade que não se subordine apenas ao modelo econômico, mas que oriente a ação política e reconstrua a solidariedade social, à qual deveriam estar subordinados o modelo econômico e todos os demais. "225

Espera-se que em Serra da Mesa o passado seja mantido vivo na memória da comunidade, representando até mesmo um motivo de orgulho para as gerações futuras. Para tanto, faz-se necessário criar, através da educação, mecanismos que repassem às novas gerações as informações adequadas sobre o tema, num esforço conjunto de técnicos e autoridades públicas.

É preciso evitar que as informações obtidas com a pesquisa de salvamento arqueológico na região fiquem restritos aos grupos que tiveram o privilégio de estarem envolvidos nos trabalhos de pesquisa, mantendo assim o ciclo vicioso da cultura elitizada, tão comum na sociedade brasileira. É fundamental que essas informações, bem como os vestígios de cultura material resgatados na área possam ser desfrutados pela comunidade que, afinal de contas, foi o elemento gerador dessa cultura local. Uma forma de se efetivar essa proposta é a criação, nos próprios municípios envolvidos no processo, de museus abertos à visitação pública, onde sejam mantidos, de forma adequada e criteriosa, todos os bens patrimoniais resgatados no processo de salvamento.

Não se trata, efetivamente, de uma tarefa fácil. De acordo com Lorêdo,

"os objetos arqueológicos reagem diferentemente quando de sua exposição ao ar livre, dependendo dos materiais de que são constituídos (...). A conservação ativa de vestígios arqueológicos é uma tarefa um tanto ou quanto diferente e mais complexa do que aquela de objetos artísticos e históricos, compreendendo o tratamento de artefatos de naturezas as mais variadas, oriundos de meios os mais diversos e, portanto, apresentando-se em condições de deterioração de maior ou menor grau." 226

\footnotetext{
${ }^{225}$ BORTOLOZZI. \& PEREZ FILHO.A. Crise ambiental da modernidade e a produção do espaço-lugar do não cidadão. Boletim Paulista de Geografia, n. 76, 1999, p. 11.

${ }^{226}$ LORÊDO. Conservação arqueológica, Revista do Patrimônio Histórico e Artístico Nacional, n.22, 1987 , p. 215 .
} 
Dessa forma, há que se compreender que a instalação de museus requererá investimentos na adequação dos imóveis e no treinamento de pessoal. Além disso, é necessário que, paralelamente, sejam desenvolvidos trabalhos no sentido de efetivar a questão educacional sobre o tema, ou seja, é imperativo que sejam criados cursos e/ou palestras, sobretudo nas escolas, mas não exclusivamente aí, de forma que a comunidade possa ter acesso ao conhecimento do seu passado, para que, a partir de então, aprenda a valorizar o seu próprio patrimônio cultural. Se a questão educacional for atingida de forma efetiva, o patrimônio que não foi afetado pela represa da hidrelétrica passará a ser considerado como sendo um elemento importante, constituidor da própria história dessa comunidade, e poderá/deverá ser então, valorizado como tal.

A criação de valores é fundamental dentro de qualquer sociedade. Um grupo social só o é na medida em que se distingue dos demais, e, para tanto, a internalização dos valores culturais que lhe são próprios é essencial.

"Quando nós musealizamos objetos, ou seja, quando recolhemos objetos como testemunhos, nós os musealizamos porque eles são testemunhos, são documentos e têm fidelidade. (...) Eles são, na realidade, testemunhos do homem e do seu meio. (...) o fundamental nessa relação do homem com a realidade, do homem com a natureza inclusive, é este sentido de percepção e valoração. Como o homem é um animal que trabalha, que atribui significados, que estabelece valores, exatamente porque ele esta elece valores, essa escala hierarquizada de valores criada pelo homem vai constituir o seu patrimônio."227

$\mathrm{Na}$ área em questão, pode ocorrer a necessidade de se resgatar, também, a valorização desse patrimônio. Como já foi colocado anteriormente, em áreas de mineração, o valor histórico está sempre relegado a segundo plano, em detrimento do valor econômico. Dessa forma, tudo aquilo que não reluz pelo ouro carece de ser identificado como sendo de valor, mesmo que seja de valor histórico. Diante de uma atitude predominante de depredação ao longo dos séculos, não é comum o interesse na preservação. No entanto, tal fato só serve para demonstrar a urgência de uma política preservacionista, em que os valores culturais tenham o seu merecido destaque.

${ }^{227}$ RÚSSIO. In: ARANTES. Texto III, Produzindo o Passado, 1984, p.61. 
Para se construir uma sociedade economicamente mais igualitária, socialmente mais justa, ecologicamente mais comprometida e culturalmente mais fortalecida, a educação é o caminho mais seguro. Nenhuma nação constrói o seu futuro sem que o seu povo saiba valorizar o seu passado e a sua memória cultural.

No momento atual, um outro elemento há que ser considerado. É a questão da percepção da realidade, do patrimônio físico-natural e do patrimônio ambiental, que se constituem, na atual conjuntura, como um dado essencialmente cultural, e como um elemento passível de preservação. Diante do quadro que se desenhou na área da pesquisa, com a destruição de vários exemplares desse patrimônio, como colocar a questão para o público e a comunidade local?

Em se tratando de uma situação em que a irreversibilidade do quadro era definitiva, o que poderia ser feito efetivamente o foi: o registro, com um maior número possível de meios para fazê-lo, de todos os aspectos desses sítios e localidades. Hoje, o caminho que se pode tomar dentro dessas comunidades é talvez a busca da preservação dos elementos paisagísticos e naturais remanescentes, considerando-os como um elemento cultural, como efetivamente o são, e efetuando, tanto quanto possível uma ocupação e exploração racional dos mesmos uma vez que o crescimento econômico inviabiliza a preservação do patrimônio natural a não ser em condições geográficas específicas (cabeceiras de cursos d'água, regiões de cotas altimétricas mais elevadas, matas ciliares, áreas de cobertura vegetal muito degradadas, etc.).

Para a região de Serra da Mesa, bem como para o Brasil, a chave que abrirá as portas de um futuro mais digno é a educação. Desde o descobrimento, as riquezas naturais e as belezas do território foram propagadas à exaustão.

"O continente do Brasil com razão é julgado a maior $e$ mais excelente parte de todo o Novo Mundo; sendo açuradamente examinado, será tido por não menos aprazível e saudável. De sorte que pode competir com quaisquer regiões da Europa ou da Ásia não só quanto à temperatura, mas também quanto à salubridade do ar, das águas e dos lugares. (...) O lado voltado para o Oriente entesta com os etíopes ocidentais, havendo de permeio um mar vastíssimo. Daí resulta que a terra 
é habitada não só com vantagem para a saúde e vida, como por prazer do espírito.",228

No entanto, a despeito de todo o potencial, o Brasil tem-se constituído no eterno país do futuro. Mas se ações concretas não forem efetivadas no presente, estaremos mais uma vez nos colocando em desvantagem no cenário mundial. Na atualidade, a sociedade brasileira precisa ser tratada com mais dignidade e respeito, e seus interesses mais amplamente defendidos. Cabe a todos nós, profissionais da educação e/ou das ciências humanas buscar uma prática mais voltada para nós mesmos e mais comprometida com a realidade do país.

Toda pesquisa deve contribuir, de alguma forma, tanto com o crescimento profissional do pesquisador quanto com a sociedade em que está inserida. Para nós, no entanto, trabalhar em Serra da Mesa significou muito mais do que isso. Foi a partir dessa experiência que nos foi possível conhecer novas paisagens; conviver com outros aspectos culturais de uma sociedade rural interiorana; experienciar um outro clima, muito mais inóspito e difícil; conhecer novos amigos, realizar novas vivências e experiências; crescer tanto no campo profissional quanto pessoal; realizar novos aprendizados: aprendizado geográfico, aprendizado histórico, aprendizado humano. Durante três anos de pesquisa também tivemos que sofrer, afligir-nos, enfrentar dificuldades. Mas, sobretudo desenvolver essa pesquisa tornou-nos profissionais mais conscientes do nosso papel na sociedade, possibilitou-nos aprender a ter mais respeito e reverência ao passado e, acima de tudo, fé no futuro.

Ao final desse trabalho, o que pretendemos é considerar que, a despeito de tudo o que foi realizado e vivido, acreditamos que somente através de um modelo educacional mais amplo e efetivamente democrático, embasado por políticas sérias de desenvolvimento social, será possível resgatar a dignidade das comunidades que constituem a sociedade brasileira. A valorização do elemento cultural, dentro desse modelo educacional, é, para nós, de fundamental importância. Acreditamos também que não basta, no entanto, teorizar sobre o tema, é mister efetivar o papel da educação na construção de uma nova sociedade brasileira. Essa sociedade necessita, fundamentalmente, do desenvolvimento econômico aliado ao desenvolvimento social. A cidadania só pode ser alcançada por indivíduos que, tanto quanto

\footnotetext{
${ }^{228}$ PISO citado por AB'SABER. Ambiente e culturas. Revista do Patrimônio Histórico e Artístico Nacional, n.22, 1987, p.250.
} 
valorizados, aprendem a valorizar: valorizar o passado, o meio ambiente, a paisagem, dentre outros, como expressões culturais que realmente o são.

Obviamente que é preciso ter muito cuidado para não cairmos no erro do reducionismo diante de uma questão tão complexa, que demanda

“remeter à uma análise mais profunda da sociedade $e$ portanto também de como se dá a sua organização espaço/territorial como pano de fundo para a explicação das causas que agravam a degradação ambiental produzindo cada vez mais espaços de não cidadania.",229

Certamente que cidadania implica também direitos sociais e garantia de uma boa qualidade de vida. Mas, mesmo para pleitear e lutar por tais direitos, é preciso enfatizar a importância da educação. Só ela poderá capacitar e formar o verdadeiro cidadão, agente histórico e modificador da realidade.

Para nós, na região de Serra da Mesa, é a educação o caminho que levará a comunidade local a aprender a valorizar e respeitar o seu passado, bem como as expressões materiais que dele se originam. A criação de museus será muito importante, porque devolverá à comunidade os bens que por direito lhe pertencem. Mas se não forem criados mecanismos de divulgação da importância desses bens eles se constituirão em meros objetos expostos, sem significado ou valor. Tanto quanto as paisagens, no entanto, eles constituem o testemunho vivo de uma história e de um passado, que não pode, sob nenhum aspecto, ser negligenciado em nome da modernização ou do progresso. Os bens culturais resgatados em Serra da Mesa pertencem por direito àquela comunidade, mas são também, antes de tudo, uma parte da história do país, e como tal precisam ser valorizados.

É preciso crer que as futuras gerações saibam cuidar melhor desse patrimônio natural e cultural do que a atual sociedade tem feito até então. Legar a eles condições para tanto é um dever, e uma forma de fazê-lo é divulgando esse patrimônio, vestígios de um passado que também é o de todos os brasileiros. Não é aconselhável que Serra da Mesa fique relegada ao esquecimento; o ideal é que seja mais divulgada e mais pesquisada, pois conhecendo melhor o 
passado, será possível construir-se um futuro melhor. Ainda se faz necessário incentivar ações positivas, que possam contribuir para a formação de cidadãos cônscios de seus deveres, aptos a exercerem seus direitos e, ainda, capazes de se orgulhar de suas origens. No Brasil, torna-se muito comum a preocupação em se dissimular sentimentos positivos em relação ao próprio país. No entanto, cabe lembrar que grandes nomes da cultura e da história nacionais eram pessoas que souberam expressar tais sentimentos, a despeito das dificuldades que o país sempre enfrentou. A crítica é sempre bem vinda, quando positiva e esclarecedora. Buscar pontos negativos dentro da sociedade (pretérita ou atual) é sempre tarefa fácil. Mas não é suficiente. Se não se buscarem os caminhos de mudança, serão sempre discurso vazio.

Encerra-se esse trabalho com a descrição que Couto de Magalhães faz da região de Serra da Mesa: é um poema de êxtase à beleza regional, que nos remete a refletir sobre a necessidade de se divulgar esse patrimônio paisagístico às demais parcelas da sociedade que a desconhecem, e pela sua grandiloqüência supera todo e qualquer discurso. É um texto que, no entanto, faz meditar sobre os problemas da preservação e da elaboração da consciência ambiental. Se essa sociedade souber valorizar e cuidar do seu patrimônio, terá dado um grande passo para garantir o bem estar social e a emancipação cultural das gerações futuras.

"Existe, cerca de uma légua distante deste arraial [Santa Rita], um pequeno alto, cujo ponto de vista é tão vasto e grandioso como as vistas do oceano; os olhos do viajante estendem-se para o norte até onde a vista humana pode alcançar, sem encontrar o menor obstáculo. A Serra do AcabaSaco vai sucessivamente abaixando-se até que de todo se confunde com as planícies. Parei extasiado nesse lugar e, enquanto a vista me representava essas planícies sem fim, sucedendo-se umas às outras, como as ondas do oceano, até que de todo se iam perder nos espaços azulados do céu, meu espírito sentia-se abatido por uma espécie de saudade, que eu não sabia dizer de que, e a imaginação me representava completamente desertas essas férteis e infinitas campinas. "230

\footnotetext{
${ }^{229}$ BORTOLOZZI \& PEREZ FILHO. Crise ambiental da modernidade e a produção do espaço-lugar do não cidadão, Boletim Paulista de Geografia, n.76, 1999, p. 15.

${ }^{230}$ MAGALHÃES citado em: UNIVERSIDADE FEDERAL DE MINAS GERAIS, Salvamento histórico arqueológico na área atingida pela represa de Serra da Mesa - Goiás, vol. 1, 1998, p. 38-39.
} 
BIBLIOGRAFIA 


\section{REFERÊNCIAS BIBLIOGRÁFICAS}

ABDALLA, Sandra L. F. O meio ambiente e a estruturação de bacias hidrográficas. 1987. 161 f. Dissertação (Mestrado) - Instituto de Geociências e Ciências Exatas da UNESP, Rio Claro.

AB'SABER, Azis. Ambiente e culturas: equilíbrio e ruptura no espaço geográfico ora chamado de Brasil. Revista do Patrimônio Histórico e Artístico Nacional, Rio de Janeiro, n. 22, p..236-253, 1987.

AB'SABER, Azis. Espaço territorial e proteção ambiental. Terra Livre: Geografia e Questão Ambiental ,São Paulo,n.3, p. 9-31, 1988.

AGUIAR, Maria do A. A. Terras de Goiás - estrutura fundiária: 1850-1920. 1998. $201 \mathrm{f}$. Dissertação (Mestrado) - Departamento de História da Universidade Federal de Goiás, Goiânia.

AIRES DE CASAL, P $\mathrm{P}^{\mathrm{e}}$. Manuel. Corografia brasílica ou relação histórico-geográfica do Reino do Brasil. São Paulo: Editora da Universidade de São Paulo; Belo Horizonte: Itatiaia, 1976.

AJARA, Cesar. A abordagem geográfica: suas possibilidades no tratamento da questão ambiental. In: MESQUITA, Olindina V.; SILVA, Solange T. (Coord.). Geografia e questão ambiental. Rio de Janeiro: IBGE, Departamento de Geografia, 1993. p. 9-11.

AMARAL, Dulce Vidigal. A cartografia a serviço do "imaginário" no tempo e no espaço. Espaço e Geografia,_Brasília, v. 2, n. 1, p. 33- 34 , 1999. 
ANDRADE, Manuel Correia. Formação Territorial do Brasil. In: CHRISTOFOLETTI et alli (Coord.). Geografia e meio ambiente no Brasil. São Paulo, Rio de Janeiro: Hucitec, 1995. p. $163-180$.

ANDRADE, Manuel Correia. Populismo e organização social do espaço. Revista Geografia e Ensino, Belo Horizonte, v. 2, nº 8, p. 46-54, 1988.

ARANTES, Antônio Augusto. Documentos históricos, documentos de cultura. Revista do Patrimônio Histórico e Artístico Nacional, Rio de Janeiro, n. 22, p. 48-55, 1987.

ARANTES, Antônio Augusto (Org.). Produzindo o passado: estratégias de construção do patrimônio cultural. São Paulo: Brasiliense, 1984.

ARRUDA, Rinaldo S. V. A contribuição dos estudos antropológicos na elaboração dos relatórios de impacto sobre o meio ambiente. In: SIMPÓSIO SOBRE POLÍTICA NACIONAL DO MEIO AMBIENTE E PATRIMÔNIO CULTURAL, 1996, Goiânia. Atas... Goiânia: Universidade Católica de Goiás, Instituto Goiano de Pré-História e Antropologia, 1996. p.138-144.

ATAÍDES, Heloísa S. F. Capel; SOUZA, Marcos A. T. Cultura material - uma fonte legítima? As contribuições da história e da arqueologia para o debate. Revista de Divulgação Científica , Goiânia, v. 2, p. 81-93, 1998.

ATAÍDES, Jézus Marco; MACHADO, Laís A.; SOUZA, Marcos A. T. Cuidando do patrimônio cultural. Goiânia: Editora da Universidade Católica de Goiás, 1997.

BECKER, Bertha K. A (des)ordem global, o desenvolvimento sustentável e a Amazônia. In: CHRISTOFOLETTI, A. et. alli. (org.). Geografia e meio ambiente no Brasil. São Paulo - Rio de Janeiro: HUCITEC, 1995. p. 46-64. 
BERRÍOS, Rolando. Planificação e planejamento ambiental no Brasil. Terra Livre: Geografia e Questão Ambiental, São Paulo, n. 3, p. 55-64, 1988.

BERTRAN, Paulo. História da Terra e do Homem no Planalto Central: Eco-história do Distrito Federal: do indígena ao colonizador. Brasília: Solo, 1994.

BERTRAN, Paulo. Formação Econômica de Goiás. Goiânia: Oriente, 1978.

BIRKHOLZ, Lauro Bastos. A recreação no planejamento de bacias hidrográficas. In: BRUNA, Gilda Collet. (Org.). Questões de organização do espaço territorial. São Paulo: Nobel/Ed. USP, 1983. P. 93-102.

BITOUN, Jean; GUIMARÃES NETO, Leonardo; ARAÚJO, T. Bacelar. Amazônia e Nordeste: os trópicos brasileiros e o desenvolvimento auto-sustentável. In: BECKER, Berta K. (Org.). Geografia e meio ambiente no Brasil. São Paulo: Hucitec, 1995. P. 250-279.

BORTOLOZZI, Arlêude; PEREZ FILHO, Archimedes. Crise ambiental da modernidade e a produção do espaço-lugar do não cidadão. Boletim Paulista de Geografia, São Paulo, n. 76, p. 7-21, dez. 1999.

BOSI, Vera. Participação e pesquisa na preservação do patrimônio cultural. Revista do Patrimônio Histórico e Artístico Nacional, Rio de Janeiro, n. 22, p. 138-144, 1987.

BRAGA, Ricardo A. Pessoa. Avaliação de impactos ambientais: uma abordagem sistêmica. Terra Livre: Geografia e Questão Ambiental, São Paulo, n. 3, p. 65-74, 1988.

BRANCO, Samuel M.; ROCHA, Aristides A. Poluição, proteção e usos múltiplos de represas. São Paulo: Nobel; Brasília: INL, 1983. 
BRANDÃO, A. J. Costa. Almanach da Província de Goyaz, para o ano de 1886. Goiânia, Editora. da Universidade Federal de Goiás, 1978.

BRASIL, Americano do. Súmula de História de Goiás; edição anotada por Humberto Crispim Borges, Goiânia: UNIGRAF, 1982.

BRASIL. Secretaria do Patrimônio Histórico e Artístico Nacional. Restauração e revitalização de núcleos históricos: análise face à experiência francesa. Brasília, 1980.

CALDARELLI, Carlos Eduardo. O licenciamento ambiental e a competência dos órgãos de proteção ao patrimônio cultural brasileiro. In: SIMPÓSIO SOBRE POLÍTICA NACIONAL do MEIO AMBIENTE e PATRIMÔNIO CULTURAL, 1996, Goiânia. Atas... Goiânia: Universidade Católica de Goiás, Instituto Goiano de Pré-História e Antropologia, 1996, p. 175-186.

CALDARELLI, Solange Bezerra. Avaliação dos impactos de grandes empreendimentos sobre a base de recursos arqueológicos da nação: conceitos e aplicações. In: SIMPÓSIO SOBRE POLÍTICA NACIONAL do MEIO AMBIENTE E PATRIMÔNIO CULTURAL. Universidade Católica de Goiás, Instituto Goiano de Pré-História e Antropologia, 1996.p. 5765.

CALDEIRON, Sueli S. (Coord.). Recursos naturais e meio ambiente: uma visão do Brasil. Rio de Janeiro: IBGE, Departamento de Recursos Naturais e Estudos Ambientais, 1993.

CAMPOS, Sérgio et al. Transformação paisagística durante 15 anos na Bacia do Rio Lavapés - Botucatu (SP). Ciência Geográfica,_Bauru, v. 4, n. 11, p. 20-21, 1998.

CHAIM, Marivone M. Aldeamentos Indígenas (Goiás, 1749-1811). São Paulo: Nobel; Brasília: Fundação Nacional Pró-Memória, 1983.

CHAUÍ, Marilena. Política cultural, cultura política e patrimônio histórico. In: CUNHA, Maria Clementina Pereira (Org.). O direito à memória. São Paulo: Prefeitura Municipal, 1992. p. 37-46. 
CHOAY, Françoise. A alegoria do patrimônio. São Paulo: Estação Liberdade: Editora UNESP, 2001.

CHRISTOFOLETTI, Antônio. Abordagens ecológica e geográfica na análise de sistemas ambientais. Ciência Geográfica, Bauru, v. 5, n. 12, p. 16-21, 1999.

CHRISTOFOLETTI, Antônio. A geografia física no estudo das mudanças ambientais. In: CHRISTOFOLETTI, A. et al (Org.) Geografia e meio ambiente no Brasil. São Paulo, Rio de Janeiro: HUCITEC, 1995. p. 334-345.

COHN, Gabriel. Concepção oficial de cultura e processo cultural. Revista do Patrimônio Histórico e Artístico Nacional, Rio de Janeiro, n. 22, p. 7-10, 1987.

COSTA, Lygia Martins. A defesa do patrimônio cultural móvel. Revista do Patrimônio Histórico e Artístico Nacional, Rio de Janeiro, n. 22, p. 145-153, 1987.

COSTA, Wanderley M. As possibilidades do planejamento ambiental no Brasil. In: BECKER, Berta K.; MIRANDA, Mariana. (Org.) A geografia política do desenvolvimento sustentável. Rio de Janeiro: Editora UFRJ, 1997, p. 445-456.

COSTA, Wanderley M. O que é Valorização do Espaço. Orientação, São Paulo, n. 5, p. 9293, 1984.

CUNHA, Maria Clementina Pereira. Patrimônio histórico e cidadania: uma discussão necessária. In O direito à memória. São Paulo: Prefeitura Municipal, 1992. p. 9-11.

CUNHA, Maria Clementina Pereira (Org.). O direito à memória. São Paulo: Prefeitura Municipal, 1992.

CUSTÓDIO, Helita B. As normas de proteção ao patrimônio cultural brasileiro em face da Constituição Federal e das normas ambientais. In: SIMPÓSIO SOBRE POLÍTICA NACIONAL DO MEIO AMBIENTE E PATRIMÔNIO CULTURAL, 1996, Goiânia. Atas... 
Goiânia: Universidade Católica de Goiás, Instituto Goiano de Pré-História e Antropologia,1996. p. 162-171.

DAMIANI, Amélia L. et al. O Espaço no fim de século: a nova raridade. São Paulo: Contexto, 1999.

DAVIDOVICH, Fany. A propósito da Eco-Urb's 92: a temática urbana e a questão ambiental. In: MESQUITA, Olindina V.; SILVA, Solange T. (Coord.). Geografia e questão ambiental. Rio de Janeiro: IBGE, Departamento de Geografia, 1993. P. 13-23.

DE DECCA, Edgar S. Memória e cidadania. In: CUNHA, Maria Clementina Pereira (Org.). $O$ direito à memória. São Paulo: Prefeitura Municipal, 1992. P. 129-136.

DEFFONTAINES, Pierre. Geografia humana do Brasil. Revista Brasileira de Geografia, Rio de Janeiro, vol. 50, n. 1, p. 267-317, 1988. Número especial.

DIEGUES, Antônio Carlos. Ecologia humana e planejamento em áreas costeiras. São Paulo: NUPAUB-USP, 1996.

DIEGUES, Antônio Carlos. O mito da natureza intocada. São Paulo: Hucitec, 1996.

DIEGUES, Antônio Carlos. O patrimônio natural e o cultural: por uma visão convergente. In: SIMPÓSIO SOBRE POLÍTICA NACIONAL DO MEIO AMBIENTE E PATRIMÔNIO CULTURAL, 1996, Goiânia. Atas ... Goiânia: Universidade Católica de Goiás, Instituto Goiano de Pré-História e Antropologia, 1996. p. 135-137.

DOLLFUS, Olivier. O espaço geográfico. São Paulo, DIFEL, 1982.

DREW, David. Processos interativos homem - meio ambiente. São Paulo: DIFEL, 1986. 
DURHAM, Eunice. Texto III. In: ARANTES, Antônio Augusto (Org.). Produzindo o passado: estratégias de construção do patrimônio cultural. São Paulo: Brasiliense, p. 23-58, 1984.

ESQUEDA, Marimiriam Dias. A geoquímica da paisagem: o homem e o ambiente no espaço e no tempo. Ciência Geográfica, Bauru, v. 4, n. 10, p. 49-53, 1998.

FALCÃO, Joaquim. Política de preservação e democracia. Revista do Patrimônio Histórico e Artístico Nacional, Rio de Janeiro, n. 20, p. 45-49, 1984.

FENELON, Déa Ribeiro. Políticas culturais e patrimônio histórico. In: CUNHA, Maria Clementina Pereira (Org.). O direito à memória. São Paulo: Prefeitura Municipal , p. 29-33, 1992.

FERRARI, Onorina Fátima. Indústria. In: FUNDAÇÃO INSTITUTO BRASILEIRO DE GEOGRAFIA E ESTATÍSTICA. Geografia do Brasil: região Centro-Oeste. Rio de Janeiro, 1989, p. 171-188.

FERREIRA, Ignez C. B. O espaço geográfico no mundo atual. Espaço e Geografia, Brasília, v. 1, n. 1, p. 7-12, 1998.

FERREIRA, Solange Teresinha L. Importância e necessidade dos estudos de percepção do meio ambiente para as atividades do planejamento. Boletim de Geografia Teorética, v. 16-17, n. 31-34, p. 315-316, 1986-1987.

FIGUEIRÓ, Adriano S. Evolução do conceito de paisagem: uma breve revisão. Geosul, Florianópolis, v. 13, n. 26, p. 40-52, 1998.

FRANCO, Maria Ignez M. Lei Sarney: desafio à competência. Revista do Patrimônio Histórico e Artístico Nacional, n. 22, p. 33-35, 1987.

FUNARI, Pedro Paulo A. Arqueologia. São Paulo: Ática, 1988. 
FUNDAÇÃO INSTITUTO BRASILEIRO DE GEOGRAFIA E ESTATÍSTICA. Geografia do Brasil: região Centro-Oeste. Rio de Janeiro, 1989.

FUNDAÇÃO DA UNIVERSIDADE DE BRASÍLIA; FURNAS CENTRAIS ELÉTRICAS

S.A. Programa de salvamento da fauna na área de influência da UHE Serra da Mesa. Brasília, 1993.

FURNAS CENTRAIS ELÉTRICAS S/A. (Brasil). Projeto básico ambiental do aproveitamento hidrelétrico Serra da Mesa: implantação dos programas ambientais. [s.1.], 1996.

FURNAS CENTRAIS ELÉTRICAS S/A. (Brasil). A questão ambiental associada à usina hidrelétrica de Serra da Mesa. [s.1.], 1996.

GALINKIN, Ana Lúcia. Significando e re-significando espaços. Espaço e Geografia, Brasília, v. 1, n. 1, p. 81-85, 1998.

GOMES, Horieste. A questão ambiental: idealismo e realismo ecológico. Terra Livre: Geografia e Questão Ambiental. São Paulo, n.3, p. 33-54, 1988.

GONÇALVES, Carlos W. P. Formação sócio-espacial e questão ambiental no Brasil. In: CHRISTOFOLETTI A. et al. (Org.) Geografia e meio ambiente no Brasil. São Paulo, Rio de Janeiro: HUCITEC, 1995. P. 309-333.

GONÇALVES, Carlos W. P. Por uma geografia política da questão ambiental. Ciência Geográfica, Bauru, v. 4, n. 11, p. 11-16, 1998.

GUIMARÃES, Carlos M. O resgate de bens arqueológicos históricos em áreas de implantação de empreendimentos hidrelétricos: o caso da UHE Serra da Mesa, Go . In: SIMPÓSIO NACIONAL SOBRE POLÍTICA NACIONAL DO MEIO AMBIENTE E PATRIMÔNIO CULTURAL, 1996, Goiânia. Atas ... Goiânia: Universidade Católica de Goiás, Instituto Goiano de Pré-História e Antropologia, 1996, p. 105-113. 
GUTIERREZ, Ramón. História, memória e comunidade: o direito ao patrimônio construído. In: CUNHA, Maria Clementina Pereira (Org.). O Direito à Memória, São Paulo: Prefeitura Municipal, 1992, p. 121-127.

HAESBAERT, Rogério. Região, diversidade territorial e globalização. Geografia, Niterói, v. 1, n. 1, 1999.

IANNI, Octavio. Cultura popular. Revista do Patrimônio Histórico e Artístico Nacional, Rio de Janeiro, n. 22, p. 30-32, 1987.

INSTITUTO DO PATRIMÔNIO HISTÓRICO E ARTÍSTICO NACIONAL - IPHAN (Brasil). Cartas patrimoniais. Brasília, 1995.

JONG, Gerardo M. As grandes obras hidrenergécica; contribuição para a análise de seus efeitos regionais. In: SOUZA, Maria Adélia A. et al. (Org.). O novo mapa do mundo: natureza e sociedade de hoje; uma leitura geográfica. São Paulo: HUCITEC/ANPUR, 1994. p. $174-181$.

KASHIMOTO, Emília M. O uso de variáveis ambientais na detecção e resgate de bens préhistóricos em áreas arqueologicamente pouco conhecidas. In: SIMPÓSIO SOBRE POLÍTICA NACIONAL DO MEIO AMBIENTE E PATRIMÔNIO CULTURAL, 1996, Goiânia. Atas... Goiânia: Universidade Católica de Goiás, Instituto Goiano de Pré-História e Antropologia, 1996. p. 91-94.

KIPNIS, Renato. O uso de modelos preditivos para diagnosticar recursos arqueológicos em áreas a serem afetadas por empreendimentos de impacto ambiental. In: SIMPÓSIO SOBRE POLÍTICA NACIONAL DO MEIO AMBIENTE E PATRIMÔNIO CULTURAL, 1996, Goiânia. Atas... Goiânia: Universidade Católica de Goiás, Instituto Goiano de Pré-História e Antropologia, 1996. p. 34-4-.

KONDER, Leandro. O Estado e os problemas da política cultural no Brasil de hoje. Revista do Patrimônio Histórico e Artístico Nacional, Rio de Janeiro, n. 22, p. 11-17, 1987. 
LAVENÈRE-WANDERLEY, L. L. Impactos ambientais resultantes da construção da Usina Hidrelétrica de Assuan, no rio Nilo (Egito). Revista Geografia e Ensino, Belo Horizonte, v. 1, n. 4, p. 3-68, 1983.

LEAL, Oscar. Viagem às terras goyanas (Brazil Central). Goiânia, Editora da Universidade Federal de Goiás, 1980.

LEMOS, Carlos A. C. O que é patrimônio histórico. São Paulo: Brasiliense, 1985.

LEMOS, Carlos et al. Os (des)caminhos da preservação. In: CUNHA, Maria Clementina Pereira (Org.). O direito à memória. São Paulo: Prefeitura Municipal, 1992. p. 211-226.

LIMA, Luiz Costa. O Estado e a cultura. Revista do Patrimônio Histórico e Artístico Nacional,._Rio de Janeiro, n. 22, p. 18-21, 1987.

LIMA, Tânia Andrade. Patrimônio arqueológico, ideologia e poder. Revista de Arqueologia, Rio de Janeiro, v. 5, n. 1, p. 19-28, 1988.

LIMA, Tânia Andrade et al. A tralha doméstica em meados do século XIX: reflexos da emergência da pequena burguesia do Rio de Janeiro. Dédalo. Publicações Avulsas. Museu de Arqueologia e Etnologia - Universidade de São Paulo, São Paulo, n. 1, p. 205-230, 1989.

LOMBARDI, Giorgio. A cidade histórica como suporte da memória. In: CUNHA, Maria Clementina Pereira (Org.) O direito à memória. São Paulo: Prefeitura Municipal, 1992. p. 8187.

LOPES, Eliane. A paisagem no resgate do patrimônio histórico-cultural da UHE - Corumbá. Revista de Divulgação Científica, Goiânia, v. 2. p. 107-120, 1998.

LOPES, Regina Clara S. A propósito de política cultural. Revista do Patrimônio Histórico e Artístico Nacional, Rio de Janeiro, n. 22, p. 26-29, 1987. 
LOPES, Renato L. L.; NETTO, Oscar M. Questões, querelas e quimeras da nova lei das águas no Brasil. Espaço e Geografia, Brasília, v. 1, n. 1, p. 47-52, 1998.

LORÊDO, Wanda Martins. Conservação arqueológica. Revista do Patrimônio Histórico e Artístico Nacional, Rio de Janeiro, n. 22, p. 215-216, 1987.

LOTUFO, César A. Arqueologia e educação: uma experiência com turmas de segundo grau de colégios da rede particular de ensino da cidade do Rio de Janeiro. Dédalo. Publicações avulsas. Museu de Arqueologia e Antropologia - Universidade de São Paulo, São Paulo, n. 1.p. 93-97, 1989.

MACHADO, Laís A.; ATAÍDES, Heloísa S. F. Capel. Identidade cultural e memória objetos de construção do patrimônio histórico. Revista de Divulgação Científica, Goiânia, v. 2, p. 41-62, 1998.

MACHADO, Lucy M. C. Philadelpho. O estudo da paisagem: uma abordagem perceptiva. Revista Geografia e Ensino, Belo Horizonte, v. 2, n. 8, p. 37-45, 1988.

MAGALDI, Cássia. O público e o privado: propriedade e interesse cultural. In: $O$ direito à memória. São Paulo: Prefeitura Municipal, 1992. p. 21-24.

MAGALHÃES, Aloísio. Bens culturais: instrumento para um desenvolvimento harmonioso. Revista do Patrimônio Histórico e Artístico Nacional, Rio de Janeiro, n. 20, p. 40-44, 1984.

MAGAlHÃES, Basílio de. Expansão Geográfica do Brasil Colonial. Brasília: Brasiliana; São Paulo: Nacional, 1978.

MAMIGONIAN, Armen. Gênese e objeto da Geografia: passado e presente. Geosul, Florianópolis, v. 14, n. 28, p. 167-178, 1999. 
MARTIN, Gabriela. Informações arqueológicas. Revista Clio - Série Arqueológica. Recife, v. 1, n. 6, p. 113-120, 1990.

MARTINS, Dilamar C. O resgate de bens arqueológicos pré-históricos em áreas de implantação de empreendimentos hidrelétricos: ocaso da UHE Serra da Mesa, Go. In: SIMPÓSIO SOBRE POLÍTICA NACIONAL DO MEIO AMBIENTE E PATRIMÔNIO CULTURAL, 1996, Goiânia. Atas... Goiânia: Universidade Católica de Goiás, Instituto Goiano de Pré-História e Antropologia, 1996. p. 95-104.

MARTINS, José S. A chegada do estranho. São Paulo: Hucitec, 1993.

MELLO, João B. Ferreira. A humanização da natureza - uma odisséia para a (re)conquista do paraíso. In: MESQUITA, Olindina V.; SILVA, Solange T. (Coord.). Geografia e Questão Ambiental. Rio de Janeiro: IBGE, Departamento de Geografia, 1993. p. 31-40.

MELLO, Paulo J. C. Levantamento arqueológico para fins de diagnóstico de bens préhistóricos em áreas de implantação de empreendimentos hidrelétricos. In: SIMPÓSIO SOBRE POLÍTICA NACIONAL DO MEIO AMBIENTE E PATRIMÔNIO CULTURAL, 1996, Goiânia. Atas... Goiânia: Universidade Católica de Goiás, Instituto Goiano de PréHistória e Antropologia, 1996. p. 17-21.

MELLO, Paulo J. C. \& VIANA, Sibeli A. A situação da arqueologia de contrato na região Centro-Oeste. Revista de Divulgação Científica ${ }_{2}$ Goiânia, v. 2, p. 7-12, 1998.

MENDONÇA, Francisco A. Geografia e meio ambiente. São Paulo: Contexto, 1994.

MENDONÇA, Francisco A. O meio ambiente e as redes. Geosul, Florianópolis, v. 12, n. 24, p. 32-41, 1997.

MENESES, Ulpiano Bezerra de. Identidade cultural e patrimônio arqueológico. Revista do Patrimônio Histórico e Artístico Nacional, Rio de Janeiro, n. 20, p. 33-36, 1984. 
MENESES, Ulpiano Bezerra de. Para uma política arqueológica da SPHAN. Revista do Patrimônio Histórico e Artístico Nacional, Rio de Janeiro, n 22, p. 206-209, 1987.

MENESES, Ulpiano Bezerra.de. O patrimônio cultural entre o público e o privado. In: CUNHA, Maria Clementina Pereira (Org.). O direito à memória. São Paulo: Prefeitura Municipal , 1992. p. 189-194.

MESQUUITA, Olindina Vianna. Agricultura. In: FUNDAÇÃO INSTITUTO BRASILEIRO DE GEOGRAFIA E ESTATÍSTICA. Geografia do Brasil: região Centro-Oeste. Rio de Janeiro, 1989. P. 149-170.

MESQUITA, Olindina Vianna; SILVA, Solange T.(coord.) . Geografia e questão ambiental. Rio de Janeiro: Fundação IBGE, 1993.

MICELI, Sérgio. SPHAN: Refrigério da Cultura Oficial. Revista do Patrimônio Histórico e Artístico Nacional, Rio de Janeiro, n. 22, p. 44-47, 1987.

MINDLIN, José E. Viajantes no Brasil: viagem em torno de meus livros. Estudos Históricos, Rio de Janeiro, v. 4, n. 7, p. 35-54, 1991.

MONTEIRO, Carlos A. Figueiredo. Geografia e ambiente. Orientação, São Paulo, v. 5, p. 1927, 1984.

MONTEIRO, Carlos A. Figueiredo. A interação homem-natureza no futuro da cidade. In: CHRISTOFOLETTI, A. et al. (org.) Geografia e Meio Ambiente no Brasil. São Paulo, Rio de Janeiro: HUCITEC, 1995. p. 371-395.

MONTEIRO, Carlos A. Figueiredo. Geografia e ambiente. Orientação, São Paulo, v. 5, p. 1927, 1984.

MORAES, Antônio C. R. Meio ambiente e ciências humanas. São Paulo: Hucitec, 1994. 
MOREIRA, Ruy. A diferença e a geografia: o ardil da identidade e a representação da diferença na geografia. Geografia, Niterói, v. 1, n. 1, 1999.

MORLEY, Edna June. Fazer arqueologia: resgatar memórias. Revista do Patrimônio Histórico e Artístico Nacional, Rio de Janeiro, n. 22, p. 212-214, 1987.

MOTTA, Lia. A SPHAN em Ouro Preto: uma história de conceitos e critérios. Revista do Patrimônio Histórico e Artístico Nacional, Rio de Janeiro, n. 22, p. 108-122, 1987.

MÜLLER, Arnaldo Carlos. Hidrelétricas, meio ambiente e desenvolvimento. São Paulo: Makron Books, 1995.

MURTA, Stela Maris; GOODEY, Brian. Interpretação do patrimônio para o turismo sustentado: um guia. Belo Horizonte: SEBRAE-MG, 1995.

NOGUEIRA, Jorge Madeira. Espaço: o seu (mau) tratamento pela teoria econômica. Espaço e Geografia, Brasília, v. 1, n. 1, p. 13-24, 1998.

ORSER JR., Charles E. Introdução à arqueologia histórica. Belo Horizonte: Oficina de Livros Ltda, 1992.

PALACIN, Luís. Goiás: 1722 - 1822, estrutura e conjuntura numa Capitania de Minas. Goiânia: Oriente, 1972.

PAOLI, Maria Célia. Memória, história e cidadania: o direito ao passado. In: CUNHA, Maria Clementina Pereira (Org.). O direito à memória. São Paulo: Prefeitura Municipal, 1992. P. 25-27.

PASQUIS, Richards. O geógrafo, a gestão ambiental e a interpretação geográfica, Espaço e Geografia, Brasília, v. 2, n. 1, p. 7-20, 1998. 
PAULA, Dilma Andrade. A Light no Brasil: a história como tragédia. Ciência Geográfica, Bauru, v. 4, n. 10, p. 41-48, 1998.

PAULA, Fabiano L.; BAETA, Alenice M. Política patrimonial arqueológica no Estado de Minas Gerais - alguns aspectos. O carste, v. 12, n. 4, p. 200-202, 2000.

PEITER, Paulo César. Considerações sobre a organização espacial dos sistemas elétricos e o processo de privatização brasileiro. Geosul, Florianópolis, v. 12, n. 24, p. 42-53, 1997.

PELLEGRINI FILHO, Américo. Ecologia, cultura e turismo. Campinas: Papirus, 1993.

PERRIN, Jean B. O exemplo francês de proteção, do remanejamento e da valorização do patrimônio histórico urbano. In: BRASIL. Secretaria do Patrimônio Histórico e Artístico Nacional. Restauração e revitalização de núcleos históricos: análise face à experiência francesa. Brasília, 1980.

PICCOLO, Paulo Ravanelli. A ecologia da paisagem e a questão da gestão de recursos naturais: um ensaio teórico-metodológico realizado a partir de duas áreas da costa atlântica brasileira. 1997. 255f. Tese (Doutorado) - Instituto de Geociências e Ciências Exatas da UNESP, Rio Claro.

POHL, Johann Emanuel. Viagem no interior do Brasil. Belo Horizonte: Itatiaia; São Paulo: Editora da USP, 1976.

RAMAGEM, Sônia Bloomfield. Geografia cultural: espaço cultural. Espaço e Geografia, Brasília, v. 1, n. 1, p. 53-57, 1998.

REIS FILHO, Nestor Goulart. Espaço e memória: conceitos e critérios de intervenção. In: CUNHA, Maria Clementina Pereira (Org.) O direito à memória. São Paulo: Prefeitura Municipal, 1992. p. 167-168. 
RIBEIRO, Antônio Giacomini. Estruturas e processos na interpretação da paisagem geográfica. Boletim de Geografia Teorética, Rio Claro, v. 15, n. 29-30, p.112-114, 1985.

ROCHA, Gilberto de Miranda. A construção da usina hidrelétrica e a redivisão político territorial na área de Tucuruí (PA). 1999. 270f. Tese (Doutorado em Geografia Humana) Faculdade de Filosofia, Letras e Ciências Humanas, Universidade de São Paulo, São Paulo.

ROCKENBACH, Denise. Resgate da Identidade - Registrando um Projeto e Investigando a Relação Identidade - Espaço. 1999. 191 f. Tese (Doutorado em Geografia Humana) Faculdade de Filosofia, Letras e Ciências Humanas, Universidade de São Paulo, São Paulo.

RODRIGUES, Arlete M. A questão ambiental e a re(descoberta) do espaço: uma nova sociedade/natureza? Boletim Paulista de Geografia, São Paulo, n. 73, p. 35-71, 1994.

ROLNIK, Raquel; SEGAWA Hugo; DIÊGOLI, Leila R. Preservação e modernidade. In: CUNHA, Maria Clementina Pereira (Org.). O direito à memória. São Paulo: Prefeitura Municipal, 1992. P. 197-210.

ROSA, Luiz Pinguelli; SIGAUD, Lygia; MIELNIK, Otávio. (Coord.) Impactos de grandes projetos hidrelétricos e nucleares: aspectos econômicos e tecnológicos, sociais e ambientais. São Paulo: Marco Zero, 1988.

ROSS, Jurandyr L. S.; DEL PRETTE, Marcos Estevan. Recursos hídricos e as bacias hidrográficas: âncoras do planejamento e gestão ambiental. Revista do Departamento de Geografia, São Paulo, n. 12, p. 89-122, 1998.

ROUGERIE, Gabriel. Geosystemes et paysages: Bilan et Methodes. Paris: A.Colin, 1991.

RUBIN, Júlio Cézar R.; MELO, Jonas I. S. Geoarqueologia - critérios utilizados para a caracterização das encostas e dos dados obtidos no projeto de levantamento e resgate do 
patrimônio arqueológico da ADA pela UHE - Corumbá. Revista de Divulgação Científica, Goiânia, v. 2, p. 121-129, 1998.

RÚSSIO, Waldísia. Texto III. In: ARANTES, Antônio Augusto (Org.). Produzindo o passado: estratégias de construção do patrimônio cultural. São Paulo: Brasiliense, p. 59-78, 1984.

SALGUEIRO, Heliana Angotti (Coord.). Paisagem e arte: a invenção da natureza, a evolução do olhar, Coletânea. São Paulo: CBHA/CNPq/FAPESP, 2000.

SAMPAIO, Suzanna C. As cartas internacionais e a proteção ao patrimônio cultural brasileiro. In: SIMPÓSIO SOBRE POLÍTICA NACIONAL DO MEIO AMBIENTE E PATRIMÔNIO CULTURAL, 1996, Goiânia. Atas... Goiânia: Universidade Católica de Goiás, Instituto Goiano de Pré-História e Antropologia,1996. p. 157-158.

SANTOS, Ângelo Oswaldo A. Restaura-se o patrimônio. Revista do Patrimônio Histórico e Artístico Nacional, Rio de Janeiro, n, 22, p. 37-39, 1987.

SANTOS, Milton. O espaço geográfico como categoria filosófica. Terra Livre: O Espaço em Questão. São Paulo, n. 5, p. 9-20, 1988.

SANTOS, Milton. A Natureza do espaço: técnica e tempo; razão e emoção. São Paulo: Hucitec, 1999.

SANTOS, Milton. Pensando o espaço do homem. São Paulo: Hucitec, 1997.

SANTOS, Roberto M. G. Aspectos jurídico-processuais da proteção ao patrimônio cultural brasileiro. In: SIMPÓSIO SOBRE POLÍTICA NACIONAL DO MEIO AMBIENTE E PATRIMÔNIO CULTURAL, 1996, Goiânia. Atas... Universidade Católica de Goiás, Instituto Goiano de Pré-História e Antropologia, 1996. P. 159-161. 
SANTOS, Vera Lúcia dos. Projetos hidrelétricos de grande porte e efeitos sociais: o exemplo do topocídio provocado pela barragem de Porto Primavera. 1998. 220 f. Dissertação (Mestrado) - Instituto de Geociências e Ciências Exatas da UNESP, Rio Claro.

SCATAMACCHIA, Maria C. M.. Arqueologia e etno-história: os cronistas do século XVI. Dédalo. Publicações Avulsas. Museu de Arqueologia e Etnologia- Universidade de São Paulo, n. 1, p. 135, 1989.

SCHETTINO, Marco Paulo Fróes. Espaços do Sertão. 1995. 87 f. Dissertação (Mestrado) Departamento de Antropologia, Instituto de Ciências Humanas da Universidade de Brasília, Brasília.

SCHMITZ, Pedro Ignácio. O patrimônio arqueológico brasileiro. Revista de Arqueologia, Rio de Janeiro, v. 5, n. 1, p. 9-18, 1988.

SCHWARZ, Bill. Patrimônio histórico e cidadania: a experiência inglesa. In: CUNHA, Maria Clementina Pereira (Org.). O direito à memória. São Paulo: Prefeitura Municipal, 1992. P. $67-79$.

SILVA, Jorge Xavier. A pesquisa ambiental no Brasil: uma visão crítica. In: CHRISTOFOlETTI, A. et al. Geografia e meio ambiente no Brasil. São Paulo, Rio de Janeiro: Hucitec, 1995. p. 346-370.

SILVA, Regina Coeli P. Sobre a preservação de sítios arqueológicos brasileiros. Revista do Patrimônio Histórico e Artístico Nacional, Rio de Janeiro, n. 22, p. 210-211, 1987.

SIMÕES, Sílvio Jorge. Geoindicadores ambientais: conceitos e aplicações. Geociências, São Paulo, v. 18, n. 1, p. 41-52, 1999.

SOUZA, Edson Belo C. A Hidrelétrica de Itaipu: uma represa que (des)configura uma região. Ciência Geográfica, Bauru, v. 4, n. 10, p. 4-12, 1998. 
SOUZA, Marcos A. T. Levantamento arqueológico em projetos de larga escala - a experiência do projeto UHE - Corumbá / patrimônio histórico. Revista de Divulgação Científica, Goiânia, v. 2, p. 63-80, 1998.

SOUZA, Marcos A. T. Levantamento arqueológico, para fins de diagnóstico de bens históricos, em áreas de implantação de empreendimentos hidrelétricos. In: SIMPÓSIO SOBRE POLÍTICA NACIONAL DO MEIO AMBIENTE E PATRIMÔNIO CULTURAL, 1996, Goiânia. Atas... Goiânia: Universidade Católica de Goiás, Instituto Goiano de PréHistória e Antropologia, 1996, p. 22-27.

SOUZA FILHO, Carlos F. Marés. Bens culturais e proteção jurídica. Porto Alegre: Unidade Editorial, 1997.

SPHAN/PRÓ-MEMÓRIA. Restauração e Revitalização de Núcleos Históricos: análise face à experiência francesa. Ministério da Educação e Cultura, Brasília, 1980.

TELLES, Augusto da Silva. Centros históricos: notas sobre a política brasileira de preservação. Revista do Patrimônio Histórico e Artístico Nacional. Rio de Janeiro, n. 19, 1984.

TIBALli, Eianda F. A. A Expansão do Povoamento em Goiás, Século XIX. 1991. 137 f. Dissertação (Mestrado). Instituto de Ciências Humanas e Letras da Universidade Federal de Goiás, Goiânia.

TOLEDO, Benedito Lima. Bem cultural e identidade cultural. Revista do Patrimônio Histórico e Artístico Nacional, Rio de Janeiro, n. 20, p. 28-32, 1984.

UNIVERSIDADE FEDERAL DE MINAS GERAIS. Faculdade de Filosofia e Ciências Humanas. Departamento de Sociologia e Antropologia. Projeto: Prospecção e Salvamento Histórico-Arqueológico na Área a ser Atingida pela Represa da Usina de Serra da MesaGoiás. Belo Horizonte, 1995. 
UNVIERSIDADE FEDERAL DE MINAS GERAIS. Faculdade de Filosofia e Ciências Humans. Departamento de Sociologia e Antropologia. Salvamento histórico-arqueológico na área atingida pela represa da Usina de Serra da Mesa - Goiás; relatório final. Belo Horizonte: FUNDEP, 1998, v. 1.

VAINER, C. População, meio ambiente e conflito social na construção de hidrelétricas. In: MARTINE, G. (Org.). População e meio ambiente: Verdades e Contradições. Campinas: Editora da UNICAMP, 1993.

VALENÇA, José Rolim (Org.). Herança: a expressão visual do brasileiro antes da influência do europeu. São Paulo, Empresas Down, 1984.

VELHO, Gilberto. Antropologia e patrimônio cultural. Revista do Patrimônio Histórico e Artístico Nacional, Rio de Janeiro, n. 20, p. 37-39, 1984.

VESENTINI, José Willian. Geografia, natureza e sociedade. São Paulo: Contexto, 1997.

WALDMAN, Maurício. Ecologia e lutas sociais no Brasil. São Paulo: Contexto, 1998.

WIED, Maximilian, Prinz von. Viagem ao Brasil. Belo Horizonte: Itatiaia; São Paulo: Editora da Universidade de São Paulo, 1989.

XAVIER, Carlos A. Ribeiro. A natureza no patrimônio cultural do Brasil. Revista do Patrimônio Histórico e Artístico Nacional, Rio de Janeiro, n. 22, p. 233-235, 1987.

Y GOYA, Paula C. L. Percepção e conservação do patrimônio ambiental urbano: a cidade de Bauru. 1994. 142 f. Dissertação (Mestrado) - Instituto de Geociências e Ciências Exatas da UNESP, Rio Claro.

YI-FU TUAN. Topofilia: um estudo da percepção, atitudes e valores do meio ambiente. São Paulo/Rio de Janeiro: Difel, 1980. 
ANEXOS 


\author{
ANEXOS \\ 1. CONSTITUIÇÃO DA REPÚBLICA FEDERATIVA DO BRASIL \\ Brasília, 05 de outubro de 1988 \\ TÍTULO II \\ Dos Direitos e Garantias Fundamentais
}

\title{
CAPÍTULO I
}

Dos Direitos e Deveres Individuais e Coletivos

Art. $5^{\circ}$ - Todos são iguais perante a lei, sem distinção de qualquer natureza, garantindo-se aos brasileiros e aos estrangeiros residentes no país a inviolabilidade do direito à vida, à liberdade, à segurança e à prosperidade, nos termos seguintes:

(...)

LXXIII - qualquer cidadão é parte legítima para propor ação popular que vise a anular ato lesivo ao patrimônio público ou de entidade de que o Estado participe, à moralidade administrativa, ao meio ambiente e ao patrimônio histórico e cultural, ficando o autor, salvo comprovada má-fé, isento de custas judiciais e do ônus da sucumbência.

\author{
TÍTULO III
}

Da Organização do Estado

\section{CAPÍtUlo II \\ Da União}

\footnotetext{
Art. $\mathbf{2 0}^{\circ}$ - São bens da União:

(...)

X. as cavidades naturais subterrâneas e os sítios arqueológicos pré-históricos, XI. as terras tradicionalmente ocupadas pelos índios.

$(\ldots)$
}

Art. $\mathbf{2 3}^{\circ}$ - É competência comum da União, dos Estados, do Distrito Federal e dos Municípios:

I. zelar pela guarda da Constituição, das leis e das instituições democráticas e conservar o patrimônio público; 
(...)

III. proteger os documentos, as obras e outros bens de valor histórico, artístico e cultural, o monumentos, as paisagens naturais notáveis e os sítios arqueológicos;

IV. impedir a evasão, a destruição e descaracterização de obras de arte e de outros bens de valor histórico, artístico ou cultural;

V. proporcionar os meios de acesso à cultura, à educação e à ciência;

VI. proteger o meio ambiente e combater a poluição em qualquer de suas formas;

(...)

Art. 24 ${ }^{\mathbf{0}}$ - Compete à União, aos Estados e ao Distrito Federal legislar concorrentemente sobre:

(...)

VII. proteção ao patrimônio histórico, cultural, artístico, turístico e paisagístico;

VIII. responsabilidade por dano ao meio ambiente, ao consumidor, a bens e direitos de valor artístico, estético, histórico, turístico e paisagístico;

\title{
CAPÍTULO IV
}

\section{Dos Municípios}

Art. $30^{\circ}$ - Compete aos Municípios:

(...)

IX. promover a proteção do patrimônio histórico cultural local, observada a legislação fiscalizadora federal e estadual.

\section{TÍTULO VIII}

Da Ordem Social

CAPÍTULO III

Da Educação, da Cultura e do Desporto

\author{
SEÇÃO II \\ Da Cultura
}

(...)

Art. $\mathbf{2 1 6}^{\circ}$ - Constituem patrimônio cultural brasileiro os bens de natureza material e imaterial, tomados individualmente ou em seu conjunto, portadores de referência à identidade, à ação, à memória dos diferentes grupos formadores da sociedade brasileira, nos quais se incluem:

I. $\quad$ as formas de expressão;

II. os modos de criar, fazer e viver;

III. as criações científicas, artísticas e tecnológicas;

IV. as obras, objetos, documentos, edificações e demais espaços destinados às manifestações artístico-culturais;

V. os conjuntos urbanos e sítios de valor histórico, paisagístico, artístico, arqueológico, paleontológico, ecológico e científico. 
$\S \mathbf{1}^{\mathbf{0}}$ - O Poder Público, com a colaboração da comunidade, promoverá e protegerá o patrimônio cultural brasileiro, por meio de inventários, registros, vigilância, tombamento e desapropriação, e de outras formas de acautelamento e preservação.

$\$ \mathbf{2}^{\mathbf{0}}$ - Cabem à administração pública, na forma da lei, a gestão da documentação governamental e as providências para franquear sua consulta a quantos dela necessitem. culturais.

$\S 3^{\mathbf{o}}$ - A lei estabelecerá incentivos para a produção e conhecimento de bens e valores

$\S \mathbf{4}^{\mathbf{0}}$ - Os danos e ameaças ao patrimônio cultural serão punidos, na forma da lei.

$\$ 5^{\mathbf{0}}$ - Ficam tombados todos os documentos e os sítios detentores de reminiscências históricas dos antigos quilombos.

\section{LEI No 3.924, DE 26 DE JULHO DE 1961 Dispõe sobre os monumentos arqueológicos e pré-históricos}

O Presidente da República.

Faço saber que o Congresso Nacional decreta e eu sanciono a seguinte Lei:

Art. $\mathbf{1}^{\mathbf{0}}$ - Os monumentos arqueológicos ou pré-históricos de qualquer natureza existentes no $\mathrm{t}$

erritório nacional e todos os elementos que neles se encontram ficam sob guarda e proteção do Poder Público, de acordo com o que estabelece o art. 175 (art. 180. C.F. 1988) da Constituição Federal.

Parágrafo Único - A propriedade da superfície regida pelo direito comum, não inclui a das jazidas arqueológicas ou pré-históricas, nem a dos objetos nelas incorporadas na forma do art. 152 (art. 168. C.F. 1988) da mesma Constituição.

Art. $2^{\mathbf{0}}$ - Consideram-se monumentos arqueológicos ou pré-históricos:

a) as jazidas de qualquer natureza, origem ou finalidade, que representem testemunhos da cultura dos paleoameríndios do Brasil, tais como sambaquis, montes artificiais ou tesos, poços sepulcrais, jazigos, aterrados, estearias e quaisquer outras não especificadas aqui, mas de significado idêntico a juízo da autoridade competente;

b) os sítios nos quais se encontram vestígios positivos de ocupação pelos paleoameríndios, tais como grutas, lapas e abrigos sob rocha;

c) os sítios identificados como cemitérios, sepulturas ou locais de pouso prolongado ou de aldeamento "estações" e cerâmicos, nos quais se encontram vestígios humanos de interesse arqueológico ou paleoetnográfico;

d) as inscrições rupestres ou locais como sulcos de polimentos de utensílios e outros vestígios de atividade de paleoameríndios.

Art. $3^{\mathbf{o}}$ - São proibidos em todo o território nacional o aproveitamento econômico, a destruição ou mutilação, para qualquer fim, das jazidas arqueológicas ou pré-históricas conhecidas como sambaquis, casqueiros, concheiros, birbigueiras ou sarnambis, e bem assim dos sítios, inscrições e objetos enumerados nas alíneas $b, c$, e $d$ do artigo anterior antes de serem devidamente pesquisados, respeitadas as concessões anteriores e não caducas. 
Art. $4^{\mathbf{0}}$ - Toda pessoa, natural ou jurídica que, na data da publicação desta lei, já estiver procedendo, para fins econômicos ou outros, à exploração de jazidas arqueológicas ou pré-históricas, deverá comunicar à Diretoria do Patrimônio Histórico e Artístico Nacional, dentro de sessenta (60) dias, sob pena de multa de $\operatorname{Cr} \$ 10.000,00$ a $\operatorname{Cr} \$ 50.000,00$ (dez mil a cinqüenta cruzeiros), o exercício dessa atividade para efeito de exame, registro, fiscalização e salvaguarda do interesse da ciência.

Art. $5^{\circ}$ - Qualquer ato que importa na destruição ou mutilação dos monumentos a que se refere o artigo $2^{\circ}$ desta lei, será considerado crime contra o Patrimônio Nacional e, como tal, punível de acordo com o disposto nas leis penais.

Art. $6^{\mathbf{0}}$ - As jazidas conhecidas como sambaquis, manifestadas ao governo da União, por intermédio da Diretoria do Patrimônio Histórico e Artístico Nacional, de acordo com o artigo $4^{\circ}$ e registradas na forma do artigo 27 desta lei, terão precedência para estudo e eventual aproveitamento, em conformidade com o Código de Minas.

Art. $\mathbf{7}^{\mathbf{0}}$ - As jazidas arqueológicas ou pré-históricas de qualquer natureza, não manifestadas e registradas na forma dos artigos $4^{\circ}$ e $6^{\circ}$ desta Lei, são consideradas, para todos os efeitos bens patrimoniais da União.

\section{CAPÍTULO II}

\section{Das Escavações Arqueológicas Realizadas por Particulares}

Art. $\mathbf{8}^{\mathbf{0}}$ - O direito de realizar escavações para fins arqueológicos, em terras de domínio público ou particular, constitui-se mediante permissão do Governo da União, através da Diretoria do Patrimônio Histórico e Artístico Nacional, ficando obrigado a respeitá-lo o proprietário ou possuidor do solo.

Art. $9^{\circ}$ - O pedido de permissão deve ser dirigido à Diretoria do Patrimônio Histórico e Artístico Nacional, acompanhado de indicação exata do local, do vulto e da duração aproximada dos trabalhos a serem executados, da prova de idoneidade técnico-científica e financeira do requerente de do nome do responsável pela realização dos trabalhos.

Parágrafo Único. Estando em condomínio a área em que se localiza a jazida, somente poderá requerer a permissão o administrador ou cabecel, eleito na forma do Código Civil.

Art. $\mathbf{1 0}^{\circ}$ - A permissão terá por título uma portaria do Ministro da Educação e Cultura, que será transcrita em livro próprio da Diretoria do Patrimônio Histórico e Artístico Nacional e na qual ficarão estabelecidas as condições a serem observadas ao desenvolvimento das escavações e estudos.

Art. $1^{\circ}$ - Desde que as escavações e estudos devam ser realizados em terreno que não pertença ao requerente, deverá ser anexado ao seu pedido o consentimento escrito do proprietário do terreno ou de quem esteja em uso e gozo desse direito.

\$ $\mathbf{1}^{\mathbf{0}}$ - As escavações devem ser necessariamente executadas sob a orientação do permissionário, que responderá, civil, penal e administrativamente, pelos prejuízos que causar ao Patrimônio Nacional ou a terceiros.

$\$ \mathbf{2}^{\mathbf{0}}$ - As escavações devem ser realizadas de acordo com as condições estipuladas no instrumento de permissão, não podendo o responsável, sob nenhum pretexto, impedir a inspeção dos trabalhos por delegado especialmente designado pela Diretoria do Patrimônio Histórico e Artístico Nacional, quando for julgado conveniente.

$\S 3^{\mathbf{o}}$ - O permissionário fica obrigado a informar à Diretoria do Patrimônio Histórico e Artístico Nacional, trimestralmente, sobre o andamento das escavações, salvo a ocorrência de fato excepcional, cuja notificação deverá ser feita imediatamente, para as providências cabíveis. 
Art. $\mathbf{1 2}^{\mathbf{0}}$ - O Ministro da Educação e Cultura poderá cassar a permissão concedida, uma vez que :

a) não sejam cumpridas as prescrições da presente Lei e do instrumento de concessão da licença;

b) sejam suspensos os trabalhos de campo por prazo superior a doze meses, salvo motivo de força maior, devidamente comprovado;

c) no caso de não cumprimento do parágrafo $3^{\circ}$ do artigo anterior.

Parágrafo Único - Em qualquer dos casos acima enumerados, o permissionário não terá direito à indenização.

\section{CAPÍTULO III \\ Das Escavações Arqueológicas Realizadas por Instituições Científicas Especializadas da União, dos Estados e dos Municípios}

Art. $1^{\circ}$ - A União, bem como os Estados e Municípios mediante autorização federal, poderão proceder a escavações e pesquisas, no interesse da arqueologia e da pré-história em terrenos de propriedade particular, com exceção das áreas muradas que envolvem construções domiciliares.

Parágrafo Único - A falta de acordo amigável com o proprietário da área onde situase a jazida, será esta declarada de utilidade pública e autorizada a sua ocupação pelo período necessário à execução dos estudos, nos termos do artigo 36 do Decreto-Lei no 3.365, de 21 de junho de 1941.

Art. 14 $^{\mathbf{0}}$ - No caso de ocupação temporária do terreno, para realização de escavações nas jazidas de utilidade pública, deverá ser lavrado um auto, antes do início dos estudos, no qual se descreve o aspecto exato do local.

\$ $\mathbf{1}^{\mathbf{0}}$ - Terminados os estudos, o local deverá ser restabelecido, sempre que possível, na sua feição primitiva.

§ 2 - Em caso de escavações produzirem a destruição de um relevo qualquer, essa obrigação só terá cabimento quando se comprovar que, desse aspecto particular do terreno, resultavam incontestáveis vantagens para o proprietário.

Art. 15 ${ }^{\circ}$ Em casos especiais e em face do significado arqueológico excepcional das jazidas, poderá ser promovida a desapropriação do imóvel, ou parte dele, por utilidade pública, com fundamento no artigo $5^{\circ}$, alíneas $k$ e $l$ do Decreto-Lei $\mathrm{n}^{\circ} 3.365$, de 21 de junho de 1941.

Art. $\mathbf{1 6}^{\mathbf{0}}$ - Nenhum órgão da administração federal, dos Estados ou dos Municípios, mesmo no caso do artigo 28 desta Lei, poderá realizar escavações arqueológicas ou préhistóricas sem prévia comunicação à Diretoria do Patrimônio Histórico e Artístico Nacional, para fins de registro no cadastro de jazidas arqueológicas.

Parágrafo Único - Dessa comunicação deve constar, obrigatoriamente, o local, o tipo ou a designação da jazida, o nome do especialista encarregado das escavações, os indícios que determinaram a escolha do local e, posteriormente, uma súmula dos resultados obtidos e do destino do material coletado.

\section{CAPÍTULO IV}

\section{Das Descobertas Fortuitas}

Art. $\mathbf{1 7}^{\mathbf{0}}$ - A posse e a salvaguarda dos bens de natureza arqueológica ou pré-histórica constituem, em princípio, direito imanente do Estado. 
Art. 18 - A descoberta fortuita de quaisquer elementos de interesse arqueológico ou pré-histórico, histórico, artístico ou numismático, deverá ser imediatamente comunicado à Diretoria do Patrimônio Histórico e Artístico Nacional ou aos órgãos oficiais autorizados, pelo autor do achado ou pelo proprietário do local onde tiver ocorrido.

Parágrafo Único - O proprietário ou ocupante do imóvel onde se tiver verificado o achado, é responsável pela conservação provisória da coisa descoberta, até pronunciamento e deliberação da Diretoria do Patrimônio Histórico e Artístico Nacional.

Art. $1^{\circ}$ - A infringência da obrigação imposta no artigo anterior implicará na apreensão sumária do achado, sem prejuízo da responsabilidade do inventor pelos danos que vier a causar ao Patrimônio Nacional, em decorrência da omissão.

\section{CAPÍTULO V}

\section{Da Remessa, para o Exterior, de Objetos de interesse Arqueológico ou Pré-histórico, Histórico, Numismático ou Artístico}

Art. $\mathbf{2 0}^{\mathbf{0}}$ Nenhum objeto que apresente interesse arqueológico ou pré-histórico, numismático ou artístico poderá ser transferido para o exterior, sem licença expressa da Diretoria do Patrimônio Histórico e Artístico Nacional, constante de uma "guia" de liberação na qual serão devidamente especificados os objetos a serem transferidos.

Art. $2^{\circ}$ - A inobservância da prescrição do artigo anterior implicará na apreensão do objeto a ser transferido, sem prejuízo das demais cominações legais a que estiver sujeito o responsável.

Parágrafo Único - O objeto apreendido, razão deste artigo, será entregue à Diretoria do Patrimônio Histórico e Artístico Nacional.

\section{CAPÍTULO VI}

\section{Disposições Gerais}

Art. $\mathbf{2 2}^{\mathbf{0}}$ - O aproveitamento econômico das jazidas, objeto desta lei, poderá ser realizado na forma e nas condições prescritas pelo Código de Minas, uma vez concluída a sua exploração científica, mediante parecer favorável da Diretoria do Patrimônio Histórico e Artístico Nacional ou órgão oficial autorizado.

Parágrafo Único - De todas as jazidas será preservada sempre que possível ou convenientemente, uma parte significativa, a ser protegida pelos meios convenientes, como blocos testemunhos.

Art. $\mathbf{2 3}^{\circ}$ - O Conselho de Fiscalização das Expedições Artísticas e Científicas encaminhará à Diretoria do Patrimônio Histórico e Artístico Nacional qualquer pedido de cientista estrangeiro, para realizar escavações arqueológicas ou pré-históricas na país.

Art. $2^{\mathbf{0}}$ - Nenhuma autorização de pesquisa ou de lavra para jazidas de calcário de concha, que possua as características de monumentos arqueológicos ou pré-históricos, poderá ser concedida sem audiência prévia da Diretoria do Patrimônio Histórico e Artístico Nacional.

Art. $\mathbf{2 5}^{\circ}$ - A realização de escavações arqueológicas ou pré-históricas com infringência de qualquer dos dispositivos desta lei, dará lugar à multa de Cr $\$ 5.000,00$ (cinco mil cruzeiros) a Cr\$50.000,00 (cinqüenta mil cruzeiros), sem prejuízo de sumária apreensão e conseqüente perda, para o Patrimônio Nacional, de todo o material e equipamento existente no local.

Art. $\mathbf{2 6}^{\circ}$ - Para melhor execução da presente Lei, a Diretoria do Patrimônio Histórico e Artístico Nacional poderá solicitar a colaboração de órgãos federais, estaduais, municipais, 
bem como de instituições que tenham, entre seus objetivos específicos, o estudo e a defesa dos monumentos arqueológicos e pré-históricos.

Art. $\mathbf{2 7}^{\mathbf{0}}$ - A Diretoria do Patrimônio Histórico e Artístico Nacional manterá um Cadastro dos monumentos arqueológicos do Brasil, no qual serão registradas todas as jazidas manifestadas, de acordo com o disposto nesta lei, bem como das que se tornarem conhecidas por qualquer via.

Art. $\mathbf{2 8}^{\mathbf{0}}$ - As atribuições conferidas ao Ministério da Educação e Cultura, para o cumprimento desta lei, poderão ser delegadas a qualquer unidade da Federação, que disponha de serviços tecno-administrativos especialmente organizados para a guarda, preservação e estudo das jazidas arqueológicas e pré-históricas, bem como de recursos suficientes para o custeio e bom andamento dos trabalhos.

Parágrafo Único - No caso deste artigo, o produto das multas aplicadas e apreensões de material legalmente feitas, reverterá em benefício do serviço estadual, organizado para a preservação e estudo desses monumentos.

Art. $2^{\circ}$ - Aos infratores desta lei serão aplicadas as sanções dos artigos 163 e 167 do Código Penal, conforme o caso, sem prejuízo de outras penalidades cabíveis.

Art. 30 ${ }^{\circ}$ - O Poder Executivo baixará, no prazo de 180 dias, a partir da vigência desta Lei, a regulamentação que for julgada necessária à sua fiel execução.

Art. 31 - Esta Lei entrará em vigor na data de sua publicação, revogadas as disposições em contrário.

Brasília, em 26 de julho de 1961; 140 da Independência e $73^{\circ}$ da República.

Jânio Quadros - Brigido Tinoco - Oscar Pedroso Horta - Clemente Mariani - João Agripino

\section{3. - LEI No 6.938, DE 31 DE AGOSTO DE 1981 \\ Dispõe sobre a Política Nacional do Meio Ambiente, seus fins e mecanismos de formulação e aplicação, e dá outras providências.}

O Presidente da República.

Faço saber que o Congresso Nacional decreta e eu sanciono a seguinte Lei:

Art. $1^{\circ}$ - Esta Lei, com fundamento nos incisivos VI e VII do artigo 23 e no artigo 235 da Constituição, estabelece a Política Nacional do Meio Ambiente, seus fins e mecanismos de formulação e aplicação, constitui o Sistema Nacional do Meio Ambiente, SISNAMA, e institui o Cadastro de Defesa Ambiental.

\section{Da Política Nacional do Meio Ambiente}

Art. $2^{\mathbf{0}}$ - A Política Nacional do Meio Ambiente tem por objetivo a preservação, melhoria e recuperação da qualidade ambiental propícia à vida, visando assegurar, no País, condições ao desenvolvimento sócioeconômico, aos interesses da segurança nacional e à proteção da dignidade da vida humana, atendidos os seguintes princípios: 
I - ação governamental na manutenção do equilíbrio ecológico, considerando o meio ambiente como um patrimônio público a ser necessariamente assegurado e protegido, tendo em vista o uso coletivo;

II - racionalização do uso do solo, do subsolo, da água e do ar;

III - proteção dos ecossistemas, com a preservação de áreas representativas;

$\mathrm{V}$ - controle e zoneamento das atividades potencial ou efetivamente poluidoras;

VI - incentivos ao estudo e à pesquisa de tecnologias orientadas para o uso racional e a proteção dos recursos ambientais;

VII - acompanhamento do estado da qualidade ambiental;

VIII - recuperação de áreas degradadas;

IX - proteção de áreas ameaçadas de degradação;

$X$ - educação ambiental a todos os níveis do ensino, inclusive a educação da comunidade, objetivando capacitá-la para participação ativa na defesa do meio ambiente.

Art. $3^{\mathbf{o}}$ - Para fins previstos nesta Lei, entende-se por:

I. meio ambiente; o conjunto de condições, leis, influências e interações de ordem física, química e biológica, que permite, abriga e rege a vida em todas as suas formas;

II. degradação da qualidade ambiental; a alteração adversa às características do meio ambiente;

III. poluição, a degradação da qualidade ambiental resultante das atividades que direta ou indiretamente:

a) prejudiquem a saúde, a segurança e o bem estar da população;

b) criem condições adversas às atividades sociais e econômicas;

c) afetem desfavoravelmente a biota;

d) afetem as condições estéticas ou sanitárias do meio ambiente;

e) lancem matérias ou energia em desacordo com os padrões ambientais estabelecidos.

IV. poluidor: a pessoa física ou jurídica, de direito público ou privado, responsável, direta ou indiretamente, por atividade causadora de degradação ambiental;

V. recursos ambientais: a atmosfera, as águas interiores, superficiais e subterrâneas, os estuários, o mar territorial, o solo, o subsolo, os elementos da biosfera, a fauna e a flora.

\section{Dos Objetivos da Política Nacional do Meio Ambiente}

Art. $4^{\mathbf{0}}$ - A Política Nacional do Meio Ambiente visará:

I. à compatibilização do desenvolvimento econômico social com a preservação da qualidade do meio ambiente e do equilíbrio ecológico;

II. à definição de áreas prioritárias de ação governamental relativa à qualidade e o equilíbrio ecológico, atendendo aos interesses da União, dos Estados, do Distrito Federal, dos Territórios e dos Municípios;

III. ao estabelecimento de critérios e padrões de qualidade ambiental e de normas relativas ao uso e manejo de recursos ambientais;

IV. ao desenvolvimento de pesquisas e de tecnologias nacionais orientadas para o uso racional de recursos ambientais;

V. à difusão de tecnologias de manejo do meio ambiente, à divulgação de dados e informações ambientais e à formação de uma consciência pública sobre a necessidade de preservação da qualidade ambiental e do equilíbrio ecológico; 
VI. à preservação e restauração dos recursos ambientais com vistas à sua utilização racional e disponibilidade permanente, concorrendo para a manutenção do equilíbrio ecológico propício à vida;

VII. à imposição, ao poluidor e ao predador, da obrigação de recuperar e/ou indenizar os danos causados e, ao usuário, da contribuição pela utilização de recursos ambientais com fins econômicos.

Art. $5^{\mathbf{o}}$ - As diretrizes da Política Nacional do Meio Ambiente, serão formuladas em normas e planos, destinados a orientar a ação dos governos da União, dos Estados, do Distrito Federal, dos Territórios e dos Municípios no que se relaciona com a preservação da qualidade ambiental e manutenção do equilíbrio ecológico, observados os princípios estabelecidos no artigo $2^{\circ}$ desta lei.

Parágrafo Único. As atividades empresariais públicas ou privadas serão exercidas em consonância com as diretrizes da Política Nacional do Meio Ambiente.

\section{Do Sistema Nacional do Meio Ambiente}

Art. $6^{0}$ - Os órgãos e entidades da União, dos Estados, do Distrito Federal, dos Territórios e dos Municípios, bem como as fundações instituídas pelo Poder Público, responsáveis pela proteção e melhoria da qualidade ambiental, constituirão o Sistema Nacional do Meio Ambiente, SISNAMA, assim estruturado:

I. Órgão Superior: o Conselho de Governo, com a função de assessorar o Presidente da República na formulação da política nacional e nas diretrizes governamentais para o meio ambiente e recursos ambientais;

II. Órgão Consultivo e Deliberativo: o Conselho Nacional do Meio Ambiente, CONAMA, com a finalidade de assessorar, estudar e propor ao Conselho de Governo diretrizes de políticas governamentais para o meio ambiente, os recursos naturais e deliberar, no âmbito de sua competência, sobre normas e padrões compatíveis com o meio ambiente ecologicamente equilibrado e essencial à sadia qualidade de vida;

III. Órgão Central: a Secretaria do Meio Ambiente da Presidência da República, com a finalidade de planejar, coordenar, supervisionar e controlar, como órgão federal, a política nacional e as diretrizes governamentais fixadas para o meio ambiente;

IV. Órgão Executor: o Instituto Brasileiro do Meio Ambiente e dos Recursos Naturais Renováveis, com a finalidade de executar e fazer executar, como órgão federal, a política e diretrizes governamentais fixadas para o meio ambiente;

V. Órgãos Seccionais: os órgãos ou entidades estaduais, responsáveis pela execução de programas, projetos e pelo controle e fiscalização de atividades capazes de provocar a degradação ambiental;

VI. Órgãos Locais: os órgãos ou entidades municipais responsáveis pelo controle e fiscalização dessas atividades, nas suas respectivas jurisdições;

$\$ \mathbf{1}^{\mathbf{0}}$ - Os Estados, na esfera de suas competências e nas áreas de sua jurisdição, elaborarão normas supletivas e complementares e padrões relacionados com o meio ambiente, observados os que forem estabelecidos pelo CONAMA.

$\$ \mathbf{2}^{\mathbf{0}}$ - Os municípios, observadas as normas e os padrões federais e estaduais, também poderão elaborar as normas mencionadas no parágrafo anterior.

$\S 3^{\mathbf{0}}$ - Os órgãos central, setoriais, seccionais e locais mencionados neste artigo deverão fornecer os resultados das análises efetuadas e sua fundamentação, quando solicitados por pessoa legitimamente interessada. 
$\$ \mathbf{4}^{\mathbf{0}}$ - De acordo com a legislação em vigor, é o Poder Executivo autorizado a criar uma Fundação de apoio técnico e científico às atividades do IBAMA.

\section{Do Conselho Nacional do Meio Ambiente}

Art. $7^{\mathbf{0}}$ - (Revogado)

Art. $8^{\circ}$ - Compete ao CONAMA:

I. estabelecer, mediante proposta do IBAMA normas e critérios para o licenciamento de atividades efetiva ou potencialmente poluidoras, a ser concedido pelos Estados e supervisionado pelo IBAMA;

II. determinar, quando julgar necessário, a realização de estudos das alternativas e das possíveis consequiências ambientais de projetos públicos ou privados, requisitando aos órgãos federais, estaduais e municipais, bem assim a entidades privadas, as informações indispensáveis para apreciação dos estudos de impacto ambiental, e respectivos relatórios, no caso de obras ou atividades de significativa degradação ambiental, especialmente nas áreas consideradas patrimônio nacional;

III. decidir, como última instância administrativa em grau de recursos, mediante depósito prévio, sobre as multas e outras penalidades impostas pelo IBAMA;

IV.homologar acordos visando à transformação de penalidades pecuniárias na obrigação de executar medidas de interesse para a proteção ambiental (vetado);

V. determinar, mediante representação do IBAMA, a perda ou restrição de benefícios fiscais concedidos pelo Poder Público, em caráter geral ou condicional, e a perda ou suspensão de participação em linhas de financiamento em estabelecimentos oficiais de crédito;

VI. estabelecer, privativamente, normas e padrões nacionais de controle da poluição por veículos automotores, aeronaves e embarcações, mediante audiência dos Ministérios competentes;

VII. estabelecer normas, critérios e padrões relativos ao controle eà manutenção da qualidade do meio ambiente com vistas ao uso racional dos recursos ambientais, principalmente os hídricos.

Parágrafo Único - O Secretário do Meio Ambiente é, sem prejuízo de suas funções, o Presidente do CONAMA.

\section{Dos Instrumentos da Política Nacional do Meio Ambiente}

Art. $9^{\circ}$ - São instrumentos da Política Nacional do Meio Ambiente:

I. o estabelecimento de padrões de qualidade ambiental;

II. o zoneamento ambiental;

III. a avaliação de impactos ambientais;

IV. o licenciamento e a revisão de atividades efetiva ou potencialmente poluidora;

V. os incentivos à produção e instalação de equipamentos e a criação ou absorção de tecnologia, voltados para a melhoria da qualidade ambiental;

VI. a criação de espaços territoriais, especialmente protegidos pelo Poder Público Federal, estadual e municipal, tais como áreas de proteção ambiental, de relevante interesse ecológico e reservas extrativistas;

VII. o Sistema Nacional de Informações sobre o Meio Ambiente; Ambiental;

VIII. o Cadastro Técnico Federal de Atividades e Instrumentos de Defesa 
IX. as penalidades disciplinares ou compensatórias ao não-cumprimento das medidas necessárias à preservação ou correção da degradação ambiental;

X. a instituição do Relatório de Qualidade do Meio Ambiente, a ser divulgado anualmente pelo Instituto Brasileiro do Meio Ambiente e Recursos Naturais Renováveis, IBAMA;

XI. a garantia da prestação de informações relativas ao Meio Ambiente, obrigandose ao Poder Público a produzi-las, quando inexistentes;

XII. o Cadastro Técnico Federal de atividades potencialmente poluidoras e/ou utilizadoras dos recursos ambientais.

Art. $\mathbf{1 0}^{\mathbf{0}}$ - A construção, instalação, ampliação e funcionamento de estabelecimentos e atividades utilizadoras de recursos ambientais, considerados efetiva e potencialmente poluidores, bem como os capazes, sob qualquer forma, de causar degradação ambiental, dependerão de prévio licenciamento de órgão estadual competente, integrante do Sistema Nacional do Meio Ambiente, SISNAMA, e do Instituto Brasileiro do Meio Ambiente e Recursos Naturais Renováveis, IBAMA, em caráter supletivo, sem prejuízo de outras licenças exigíveis.

$\S \mathbf{1}^{\mathbf{0}}$ - Os pedidos de licenciamento, sua renovação e a respectiva concessão serão publicados no jornal oficial do Estado, bem como em um periódico regional ou local de grande circulação.

$\$ \mathbf{2}^{\mathbf{0}}$ - Nos casos e prazos previstos em resolução do CONAMA, o licenciamento de que trata este artigo dependerá de homologação do IBAMA.

$\S 3^{\mathbf{0}}$ - O órgão estadual do meio ambiente e o IBAMA, em caráter supletivo, poderão, se necessário e sem prejuízo das penalidades pecuniárias cabíveis, determinar a redução das atividades geradoras de poluição, para manter as emissões gasosas, os efluentes líquidos e os resíduos sólidos dentro das condições e limites estipulados no licenciamento concedido.

$\S 4^{\mathbf{o}}$ - Compete ao Instituto Brasileiro do Meio Ambiente e Recursos Naturais Renováveis, IBAMA, o licenciamento previsto no caput deste artigo, no caso de atividades e obras com significativo impacto ambiental, de Âmbito nacional ou regional.

Art. $1^{\circ}$ - Compete ao IBAMA propor ao CONAMA normas e padrões para a implantação, acompanhamento e fiscalização do licenciamento previsto no artigo anterior, além das que forem oriundas do próprio CONAMA.

$\$ \mathbf{1}^{\mathbf{0}}$ - A fiscalização e o controle de aplicação de critérios, normas e padrões de qualidade ambiental serão exercidos pelo IBAMA, em caráter supletivo da atuação do órgão estadual e municipal competentes.

$\S \mathbf{2}^{\mathbf{0}}$ - Inclui-se na competência da fiscalização e controle a análise de projetos de entidades, públicas ou privadas, objetivando a preservação ou a recuperação de recursos ambientais, afetados por processos de exploração predatórios ou poluidores.

Art. $\mathbf{1 2}^{\mathbf{0}}$ - As entidades e órgãos de financiamento e incentivos governamentais condicionarão a aprovação de projetos habilitados a esses benefícios ao licenciamento, na forma desta Lei, e ao cumprimento das normas, dos critérios e dos padrões expedidos pelo CONAMA.

Parágrafo Único - As entidades e órgãos referidos no caput deste artigo deverão fazer constar dos projetos a realização de obras e aquisição de equipamentos destinados ao controle de degradação ambiental e à melhoria da qualidade do meio ambiente.

Art. $\mathbf{1 3}^{\mathbf{0}}$ - O Poder Executivo incentivará as atividades voltadas ao meio ambiente, visando:

I. ao desenvolvimento, no País, de pesquisas e processos tecnológicos destinados a reduzir a degradação da qualidade ambiental;

II. a fabricação de equipamentos antipoluidores; 
III. a outras iniciativas que propiciem a racionalização do uso de recursos ambientais.

Parágrafo Único - Os órgãos, entidades e programas do Poder Público, destinados ao incentivo das pesquisas científicas e tecnológicas, considerarão, entre as suas metas prioritárias, o apoio aos projetos que visem a adquirir e desenvolver conhecimentos básicos e aplicáveis na área ambiental e ecológica.

Art. 14 $^{\mathbf{0}}$ - Sem prejuízo das penalidades definidas pela legislação federal, estadual e municipal, o não-cumprimento das medidas necessárias à preservação ou correção dos inconvenientes e danos causados pela degradação da qualidade ambiental sujeitará os transgressores:

I. à multa simples ou diária, nos valores correspondentes, no mínimo, a 10 (dez) e, no máximo, a 1.000 (mil) Obrigações Reajustáveis do Tesouro Nacional, ORTNs, agravada em casos de reincidência específica, conforme dispuser o regulamento, vedada a sua cobrança pela União se já tiver sido aplicada pelo Estado, Distrito Federal, Territórios ou pelos Municípios;

II. à perda ou restrição de incentivos e benefícios fiscais concedidos pelo Poder Público;

III. à perda ou suspensão de participação em linhas de financiamento em estabelecimentos oficiais de crédito;

IV. à suspensão de sua atividade.

$\S \mathbf{1}^{\mathbf{0}}$ - Sem obstar a aplicação das penalidades previstas neste artigo, é o poluidor obrigado, independentemente de existência de culpa, a indenizar ou reparar os danos causados ao meio ambiente e a terceiros, afetados por sua atividade. O Ministério Público da União e dos Estados terá legitimidade para propor ação de responsabilidade civil e criminal, por danos causados ao meio ambiente.

$\$ \mathbf{2}^{\mathbf{0}}$ - No caso de omissão da autoridade estadual ou municipal, caberá ao Secretário do Meio Ambiente a aplicação das penalidades pecuniárias previstas neste artigo.

$\$ \mathbf{3}^{\mathbf{o}}$ - Nos casos previstos nos incisos II e III deste artigo, o ato declaratório da perda, restrição ou suspensão será atribuição da autoridade administrativa ou financeira que concedeu os benefícios, incentivos ou financiamento, cumprindo resolução do CONAMA.

$\$ \mathbf{4}^{\mathbf{0}}$ - Nos casos de poluição provocada pelo derramamento ou lançamento de detritos ou óleo em águas brasileiras, por embarcações e terminais marítimos ou fluviais, prevalecerá o disposto na Lei 5.357, de 17 de novembro de 1967.

Art. $1^{\circ}$ - O poluidor que expuser a perigo a incolumidade humana, animal ou vegetal, ou estiver tornando mais grave situação de perigo existente, fica sujeito à pena de reclusão de 1 (um) a 3 (três) anos e multa de 100 (cem) a 1.000 (mil) MRVs.

$\$ \mathbf{1}^{\mathbf{0}}$ - A pena é aumentada até o dobro se:

I. resultar:

a) dano irreversível à fauna, à flora e ao meio ambiente;

b) lesão corporal grave;

II. a poluição é decorrente de atividade industrial ou de transporte;

III. o crime é praticado durante a noite, em domingo ou em feriados.

$\$ \mathbf{2}^{\mathbf{0}}$ - Incorre no mesmo crime a autoridade competente que deixar de promover as medidas tendentes a impedir a prática das condutas acima citadas.

Art. $\mathbf{1 6}^{\mathbf{0}}$ - (Revogado).

Art. $\mathbf{1 7}^{\mathbf{0}}$ - Fica instituído, sob a administração do Instituto Brasileiro do Meio Ambiente e Recursos Naturais Renováveis, IBAMA:

I. Cadastro Técnico Federal de Atividades e Instrumentos de Defesa Ambiental, para registro obrigatório de pessoas físicas ou jurídicas que se dedicam à consultoria técnica sobre 
problemas ecológicos e ambientais à indústria e comércio de equipamentos, aparelhos e instrumentos destinados ao controle de atividades efetiva ou potencialmente poluidores;

II. Cadastro Técnico Federal de Atividades Potencialmente Poluidoras ou utilizadora de Recursos Ambientais, para registro obrigatório de pessoas físicas ou jurídicas que se dedicam a atividades potencialmente poluidoras e/ou extração, produção, transporte e comercialização de produtos potencialmente perigosos ao meio ambiente, assim como de produtos e subprodutos da fauna e flora.

Art. $\mathbf{1 8}^{\mathbf{0}}$ - São transformadas em reservas ou estações ecológicas sob a responsabilidade do IBAMA, as florestas e as demais formas de vegetação natural de preservação permanente, relacionadas no artigo II da Lei no 4.771, de 15 de setembro de 1965 Código Florestal, e os pousos das aves de arribação protegidos por convênios, acordos ou tratados assinados pelo Brasil com outras nações.

Parágrafo Único - As pessoas físicas ou jurídicas que, de qualquer modo, degradarem reservas ou estações ecológicas, bem como outras áreas declaradas como de relevante interesse ecológico, estão sujeitas às penalidades previstas no artigo 14 desta Lei.

Art. $1^{\circ}$ - Ressalvado o disposto nas Leis $\mathrm{n}^{\circ}$ 5.357, de 17 de novembro de 1967 , e $\mathrm{n}^{\circ}$ 7.661, de 16 de maio de 1988. A receita proveniente da aplicação desta Lei será recolhida de acordo com o disposto no artigo 4 da Lei $n^{\circ} 7.735$, de 22 de fevereiro de 1989.

Art. $20^{\circ}$ - Esta Lei entrará em vigor na data de sua publicação.

Art. $21^{\circ}$ - Revogam-se as disposições em contrário.

Brasília, 31 de agosto de $1991 ; 160^{\circ}$ da Independência e $93^{\circ}$ da República.

JOÃO FIGUEIREDO, Mário Davia Andreazza.

\section{DECRETO-LEI No 25, DE 30 DE NOVEMBRO de 1937}

Organiza a proteção do Patrimônio Histórico e Artístico Nacional

O Presidente da República dos Estados Unidos do Brasil, usando da atribuição que lhe confere o art. 180 da Constituição, decreta:

\section{CAPÍTULO I}

\section{Do Patrimônio Histórico e Artístico Nacional}

Art. $\mathbf{1}^{\mathbf{0}}$ - Constitui o patrimônio histórico e artístico nacional o conjunto dos bens móveis e imóveis existentes no país e cuja conservação seja de interesse público, quer por sua vinculação a fatos memoráveis da história do Brasil, quer por seu excepcional valor arqueológico ou etnográfico, bibliográfico ou artístico.

$\$ \mathbf{1}^{\mathbf{o}}$ - Os bens a que se refere o presente artigo só serão considerados parte integrante do patrimônio histórico e artístico brasileiro, depois de inscritos separada ou agrupadamente num dos quatro livros do Tombo, de que trata o Art. 4 desta lei.

$\$ \mathbf{2}^{\mathbf{0}}$ - Equiparam-se aos bens a que se refere o presente artigo e são também sujeitos a tombamento os monumentos naturais, bem como os sítios e paisagens que importe conservar e proteger pela feição notável com que tenham sido dotados pela natureza ou agenciados pela indústria humana. 
Art. $\mathbf{2}^{\mathbf{0}}$ - A presente lei se aplica às coisas pertencentes às pessoas naturais, bem como às pessoas jurídicas de direito privado e de direito público interno.

Art. $3^{\mathbf{o}}$ - Excluem-se do patrimônio histórico e artístico nacional as obras de origem estrangeira:

1) que pertençam as repartições diplomáticas ou consulares acreditadas no país;

2) que adornem quaisquer veículos pertencentes a empresas estrangeiras, que façam carreira no país;

3) que se incluam entre os bens referidos no Art. 10 da Introdução do Código Civil, e que continuam sujeitas à lei pessoal do proprietário;

4) que pertençam a casas de comércio de objetos históricos ou artísticos;

5) que sejam trazidas para exposições comemorativas, educativas ou comerciais;

6) que sejam importadas por empresas estrangeiras expressamente para adorno dos respectivos estabelecimentos.

Parágrafo Único - As obras mencionadas nas alíneas 4 e 5 terão guia de licença para livre trânsito, fornecida pelo Serviço do Patrimônio Histórico e Artístico Nacional.

\section{CAPÍTULO II}

\section{Do Tombamento}

Art. 40- O Serviço do Patrimônio Histórico e Artístico Nacional possuirá quatro Livros do Tombo, nos quais serão inscritas as obras a que se refere o Art. 1 desta lei, a saber:

1) no Livro do Tombo Arqueológico, Etnográfico e Paisagístico, as coisas pertencentes às categorias de arte arqueológicas, etnográfica, ameríndia e popular, e bem assim as mencionadas no $\S 2$ do citado Art. 1;

2) no Livro do Tombo Histórico, as coisas de interesse histórico e as obras de arte histórica;

3) no Livro do Tombo das Belas Artes, as coisas de arte erudita, nacional ou estrangeira;

4) no Livro do Tombo das Artes Aplicadas, as obras que se incluírem na categoria das artes aplicadas, nacionais ou estrangeiras.

$\$ \mathbf{1}^{\mathbf{0}}$ - Cada um dos Livros do Tombo poderá ter vários volumes.

$\$ \mathbf{2}^{\mathbf{0}}$ - Os bens, que se incluem nas categorias enumeradas nas alíneas 1, 2, 3 e 4, do presente artigo, serão definidos e especificados no regulamento que for expedido para execução da presente lei.

Art. $5^{\circ}$ - O tombamento dos bens pertencentes à União, aos Estados e aos Municípios se fará de ofício, por ordem do diretor do Serviço do Patrimônio Histórico e Artístico Nacional, devendo ser notificado à entidade a quem pertencer, ou sob cuja guarda estiver a coisa tombada, a fim de produzir os necessários efeitos.

Art. $\mathbf{6}^{\mathbf{0}}$ - $\mathrm{O}$ tombamento de coisa pertencente à pessoa natural ou à pessoa jurídica de direito privado se fará voluntária ou compulsoriamente.

Art. $7^{\mathbf{0}}$ - Proceder-se-á ao tombamento voluntário sempre que o proprietário o pedir e a cousa se revestir dos requisitos necessários para constituir parte integrante do patrimônio histórico e artístico nacional, a juízo do Conselho Consultivo do Serviço do Patrimônio Histórico e Artístico Nacional, ou sempre que o mesmo proprietário anuir, por escrito, à notificação, que se lhe fizer, para a inscrição da coisa em qualquer dos Livros do Tombo.

Art. $\mathbf{8}^{\mathbf{o}}$ - Proceder-se-á ao tombamento compulsório quando o proprietário se recusar a anuir à inscrição da coisa.

Art. $9^{\mathbf{0}}$ - O tombamento compulsório se fará de acordo com o seguinte processo: 
1) O Serviço do Patrimônio Histórico e Artístico Nacional, por seu órgão competente, notificará o proprietário para anuir ao tombamento, dentro do prazo de quinze dias, a contar do recebimento da notificação, ou para, se o quiser impugnar, oferecer dentro do mesmo prazo as razões de sua impugnação.

2) No caso de não haver impugnação dentro do prazo assinado, que é fatal, o diretor do Serviço do Patrimônio Histórico e Artístico Nacional mandará por simples despacho que se proceda à inscrição da coisa no competente Livro do Tombo.

3) Se a impugnação foi oferecida dentro do prazo assinado, far-se-á vista da mesma, dentro de outros quinze dias fatais, ao órgão de que houver emanado a iniciativa do tombamento, a fim de sustentá-la. Em seguida, independentemente de custas, será o processo remetido ao Conselho Consultivo do Serviço do Patrimônio Histórico e Artístico Nacional, que proferirá decisão a respeito, dentro do prazo de sessenta dias, a contar do seu recebimento. Dessa decisão não caberá recurso.

Art. 10 - O tombamento dos bens, a que se refere o Art. 6 desta lei, será considerado provisório ou definitivo, conforme esteja o respectivo processo iniciado pela notificação ou concluído pela inscrição dos referidos bens no competente Livro do Tombo.

Parágrafo Único - Para todos os efeitos, salvo a disposição do Art. 13 desta lei, o tombamento provisório se equiparará ao definitivo.

\section{CAPÍTULO III Dos Efeitos do Tombamento}

Art. 110- As coisas tombadas, que pertencem à União, aos Estados ou aos Municípios, inalienáveis por natureza, só poderão ser transferidas de uma à outra das referidas entidades.

Parágrafo Único - Feita a transferência, dela deve o adquirente dar imediato conhecimento ao Serviço do Patrimônio Histórico e Artístico Nacional.

Art. $\mathbf{1 2}^{\mathbf{0}}$ - A alienabilidade das obras históricas ou artísticas tombadas, de propriedade de pessoas naturais ou jurídicas de direito privado sofrerá as restrições constantes da presente lei.

Art. $\mathbf{1 3}^{\mathbf{o}}$ - O tombamento definitivo dos bens de propriedade particular será, por iniciativa do órgão competente do Serviço do Patrimônio Histórico e Artístico Nacional, transcrito para os devidos efeitos em livro a cargo dos oficiais do registro de imóveis e averbado ao lado da transcrição do domínio.

$\$ \mathbf{1}^{\mathbf{0}}$ - No caso de transferência da propriedade dos bens de que trata este artigo, deverá o adquirente, dentro do prazo de trinta dias, sob pena de multa de dez por cento sobre o respectivo valor, fazê-la constar do registro, ainda que se trate de transmissão judicial ou "causa mortis".

$\$ \mathbf{2}^{\mathbf{0}}$ - Na hipótese de deslocação de tais bens, deverá o proprietário dentro do mesmo prazo e sob pena da mesma multa, inscrevê-los no registro do lugar para que tiverem sido deslocados.

§ $3^{\mathbf{o}}$ - A transferência deve ser comunicada pelo adquirente, e a deslocação pelo proprietário, ao Serviço do Patrimônio Histórico e Artístico Nacional, dentro do mesmo prazo e sob a mesma pena.

Art. $\mathbf{1 4}^{\mathbf{0}}$ - A coisa tombada não poderá sair do país, senão por curto prazo, sem transferência de domínio e para fim de intercâmbio cultural, a juízo do Conselho Consultivo do Serviço do Patrimônio Histórico e Artístico Nacional.

Art. 15 $^{\mathbf{0}}$ - Tentada, a não ser no caso previsto no artigo anterior, a exportação, para fora do país, da coisa tombada, será esta sequiestrada pela União ou pelo Estado em que se encontrar. 
$\S \mathbf{1}^{\mathbf{0}}$ - Apurada a responsabilidade do proprietário, ser-lhe-á imposta a multa de cinqüenta por cento do valor da coisa, que permanecerá seqüestrada em garantia do pagamento, e até que este se faça.

$\S \mathbf{2}^{\mathbf{o}}$ - No caso de reincidência, a multa será elevada ao dobro.

$\S \mathbf{3}^{\mathbf{o}}$ - A pessoa que tentar a exportação de coisa tombada, além de incidir na multa a que se referem os parágrafos anteriores, incorrerá nas penas cominadas no Código Penal para o crime de contrabando.

Art. $1^{\mathbf{0}}$ - No caso de extravio ou furto de qualquer objeto tombado, o respectivo proprietário deverá dar conhecimento do fato ao Serviço do Patrimônio Histórico e Artístico Nacional, dentro do prazo de cinco dias, sob pena de multa de dez por cento sobre o valor da coisa.

Art. $\mathbf{1 7}^{\mathbf{0}}$ - As coisas tombadas não poderão, em caso nenhum, ser destruídas, demolidas ou mutiladas, nem, sem prévia autorização especial do Serviço do Patrimônio Histórico e Artístico Nacional, ser reparadas, pintadas ou restauradas, sob pena da multa de cinqüenta por cento do dano causado.

Parágrafo único - Tratando-se de bens pertencentes à União, aos Estados ou aos Municípios, a autoridade responsável pela infração do presente artigo incorrerá pessoalmente na multa.

Art. $\mathbf{1 8}^{\mathbf{0}}$ - Sem prévia autorização do Serviço do Patrimônio Histórico e Artístico Nacional, não se poderá, na vizinhança da coisa tombada, fazer construção que impeça ou reduza a visibilidade, nem nela colocar anúncios ou cartazes, sob pena de ser mandada destruir a obra ou retirar o objeto, impondo-se neste caso a multa de cinqüenta por cento do valor do mesmo objeto.

Art. $1^{\mathbf{0}}$ - O proprietário da coisa tombada, que não dispuser de recursos para proceder às obras de conservação e reparação que a mesma requerer, levará ao conhecimento do Serviço do Patrimônio Histórico e Artístico Nacional, a necessidade das mencionadas obras, sob pena de multa correspondente ao dobro da importância em que for avaliado o dano sofrido pela mesma coisa.

§ $\mathbf{1}^{\mathbf{0}}$ - Recebida a comunicação e consideradas necessárias as obras, o diretor do Serviço do Patrimônio Histórico e Artístico Nacional mandará executá-las, a expensas da União, devendo as mesmas ser iniciadas dentro do prazo de seis meses, ou providenciará para que seja feita a desapropriação da coisa.

$\$ \mathbf{2}^{\mathbf{0}}$ - A falta de qualquer das providências previstas no parágrafo anterior, poderá o proprietário requerer que seja cancelado o tombamento da coisa.

§ $3^{\mathbf{o}}$ - Uma vez que verifique haver urgência na realização de obras e conservação ou reparação em qualquer coisa tombada, poderá o Serviço do Patrimônio Histórico e Artístico Nacional tomar a iniciativa de projetá-las e executá-las, a expensas da União, independentemente da comunicação a que alude este artigo, por parte do proprietário.

Art. $\mathbf{2 0}^{\mathbf{0}}$ - As coisas tombadas ficam sujeitas à vigilância permanente do Serviço do Patrimônio Histórico e Artístico Nacional, que poderá inspecioná-los sempre que for julgado conveniente, não podendo os respectivos proprietários ou responsáveis criar obstáculos à inspeção, sob pena de multa de cem mil réis, elevada ao dobro em caso de reincidência.

Art. $21^{\circ}$ - Os atentados cometidos contra os bens de que trata o Art. 1 desta lei são equiparados aos cometidos contra o patrimônio nacional. 


\section{CAPÍTULO IV \\ Do Direito de Preferência}

Art. $\mathbf{2 2}^{\mathbf{0}}$ - Em face da alienação onerosa de bens tombados, pertencentes a pessoas naturais ou a pessoas jurídicas de direito privado, a União, os Estados e os Municípios terão, nesta ordem, o direito de preferência.

$\S \mathbf{1}^{\mathbf{0}}$ - Tal alienação não será permitida, sem que previamente sejam os bens oferecidos, pelo mesmo preço, à União, bem como ao Estado e ao Município em que se encontrarem. O proprietário deverá notificar os titulares do direito de preferência a usá-lo, dentro de trinta dias, sob pena de perdê-lo.

$\$ \mathbf{2}^{\mathbf{0}}$ - É nula a alienação realizada com violação do disposto no parágrafo anterior, ficando qualquer dos titulares do direito de preferência habilitado a seqüestrar a coisa e a impor a multa de vinte por cento do seu valor ao transmitente e ao adquirente, que serão por ela solidariamente responsáveis. A nulidade será pronunciada, na forma da lei pelo juiz que conceder o sequiestro, o qual só será levantado depois de paga a multa e se qualquer dos titulares do direito de preferência não tiver adquirido a coisa no prazo de trinta dias.

$\S 3^{\circ}$ - O direito de preferência não inibe o proprietário de gravar livremente a coisa tombada, de penhor, anticrese ou hipoteca.

$\S 4^{\mathbf{0}}$ - Nenhuma venda judicial de bens tombados se poderá realizar sem que, previamente, os titulares do direito de preferência sejam disso notificados judicialmente, não podendo os editais de praça ser expedidos, sob pena de nulidade, antes de feita a notificação.

$\$ \mathbf{5}^{\mathbf{0}}$ - Aos titulares do direito de preferência assistirá o direito de remissão, se dela não lançarem mão, até a assinatura do auto de arrematação ou até a sentença de adjudicação, as pessoas, que, na forma da lei, tiverem a faculdade de remir.

$\$ \mathbf{6}^{\mathbf{0}}$ - O direito de remissão por parte da União, bem como do Estado e do Município em que os bens se encontrarem, poderá ser exercido dentro de cinco dias a partir da assinatura do auto de arrematação ou da sentença de adjudicação, não se podendo extrair a carta, enquanto não se esgotar este prazo, salvo se o arrematante ou o adjudicante for qualquer dos titulares do direito de preferência.

\section{CAPÍTULO V Disposições Gerais}

Art. 23- - O Poder Executivo providenciará a realização de acordos entre a União e os Estados, para melhor coordenação e desenvolvimento das atividades relativas à proteção do patrimônio histórico e artístico nacional e para a uniformização da legislação estadual complementar sobre o mesmo assunto.

Art. $2^{\circ}$ - A União manterá, para a conservação e a exposição de obras históricas de sua propriedade, além do Museu Histórico Nacional e do Museu Nacional de Belas Artes, tantos outros museus nacionais quantos se tornarem necessários, devendo outrossim providenciar no sentido de favorecer a instituição de museus estaduais e municipais, com finalidades similares.

Art. $\mathbf{2 5}^{\mathbf{0}}$ - O Serviço do Patrimônio Histórico e Artístico Nacional procurará entendimentos com as autoridades eclesiásticas, instituições científicas, históricas ou artísticas e pessoas naturais e jurídicas, com objetivo de obter a cooperação das mesmas em benefício do patrimônio histórico e artístico nacional.

Art. $26^{\circ}$ - Os negociantes de antigüidades, de obras de arte de qualquer natureza, de manuscritos e livros antigos ou raros são obrigados a um registro especial no Serviço do 
Patrimônio Histórico e Artístico Nacional, cumprindo-lhes outrossim apresentar semestralmente ao mesmo relações completas das coisas históricas e artísticas que possuírem.

Art. $\mathbf{2 7}^{\mathbf{0}}$ - Sempre que os agentes de leilões tiverem de vender objetos de natureza idênticas à dos mencionados no artigo anterior, deverão apresentar a respectiva relação ao órgão competente do Serviço do Patrimônio Histórico e Artístico Nacional, sob pena de incidirem na multa de cinqüenta por cento sobre o valor dos objetos vendidos.

Art. $\mathbf{2 8}^{\mathbf{0}}$ - Nenhum objeto de natureza idêntica à dos referidos no Art. 26 desta lei poderá ser posto à venda pelos comerciantes ou agentes de leilões, sem que tenha sido previamente autenticado pelo Serviço do Patrimônio Histórico e Artístico Nacional, ou por perito em que o mesmo se louvar, sob pena de multa de cinqüenta por cento sobre o valor atribuído ao objeto.

Parágrafo Único - A autenticação do mencionado objeto será feita mediante o pagamento de uma taxa de peritagem de cinco por cento sobre o valor da coisa, se este for inferior ou equivalente a um conto de réis, e de mais cinco mil réis por conto de réis ou fração que exceder.

Art. $2^{\circ}$ - O titular do direito de preferência goza de privilégio especial sobre o valor produzido em praça por bens tombados, quanto ao pagamento de multas impostas em virtude de infrações da presente lei.

Parágrafo Único - Só terão prioridade sobre o privilégio a que se refere este artigo os créditos inscritos no registro competente antes do tombamento da coisa pelo Serviço do Patrimônio Histórico e Artístico Nacional.

Art. $\mathbf{3 0}^{\mathbf{0}}$ - Revogam-se as disposições em contrário.

Rio de Janeiro, em 30 de novembro de $1937 ; 116^{\circ}$ da Independência e $49^{\circ}$ da República.

GETÚLIO VARGAS; Gustavo Capanema

\section{DECRETO No 95.733, DE 12 DE FEVEREIRO DE 1988 Dispõe Sobre a Inclusão no Orçamento dos Projetos e Obras Federais, de Recursos Destinados a Prevenir ou Corrigir os Prejuizos de Natureza Ambiental, Cultural e Social Decorrentes da Execução desses Projetos e Obras.}

O Presidente da República, no uso da atribuição que lhe confere o art. 81, item III, da Constituição, e

Considerando que a execução de alguns projetos e a construção de obras federais podem causar impactos de natureza ambiental, cultural e social que exijam medidas corretivas por parte do Poder Público, envolvendo, em muitos casos, os Estados e os Municípios onde se situam esses empreendimentos;

Considerando que nem sempre as Administrações Estaduais e Municipais dispõem de recursos e infra-estrutura necessárias para agir prontamente no sentido de evitar esses impactos;

Considerando que a execução desses empreendimentos visa ao desenvolvimento, à melhoria das condições do meio e à elevação do nível de vida das comunidades envolvidas, não sendo justo que os reflexos negativos dela decorrentes causem efeitos contrários ao objetivado pelo Governo; 
Considerando, finalmente, que a execução de projetos e a construção de obras federais devem procurar manter o equilíbrio entre o avanço que imprimem ao meio e o bem-estar da população local, para que esta se beneficie dos resultados a serem alcançados.

\section{DECRETA:}

Art. $1^{\mathbf{o}}$ - No planejamento de projetos e obras de médio e grande porte executados total ou parcialmente com recursos federais, serão considerados os efeitos de caráter ambiental, cultural e social que esses empreendimentos possam causar ao meio considerado.

Parágrafo Único - Identifiquemos efeitos negativos de natureza ambiental, cultural e social, os órgãos e entidades federais incluirão no orçamento de cada projeto ou obra, dotações correspondentes, no mínimo, a $1 \%$ (um por cento) do mesmo orçamento destinadas à prevenção ou à correção desses efeitos.

Art. $2^{\mathbf{o}}$ - Os projetos e as obras já em execução ou em planejamento, serão revistos para se adaptarem ao disposto no artigo anterior.

Art. $3^{\circ}$ - Os recursos destinados à prevenção ou correção do impacto negativo causado pela execução dos referidos projetos e obras, serão repassados pelos órgãos ou entidades públicas responsáveis pela execução das medidas preventivas ou corretivas, quando não afeta ao responsável pelo projeto ou obra.

Art. $4^{\mathbf{0}}$ - Este Decreto entrará em vigor na data de sua publicação, revogadas as disposições em contrário.

\section{NORMAS PARA PROCEDIMENTOS LIGADOS À PESQUISA E PROTEÇÃO DE BENS ARQUEOLÓGICOS SUBMERSOS, NOS TERMOS DA LEI No 7.452, DE 26 DE SETEMBRO DE 1986.}

\section{PROPÓSITO}

Estabelecer procedimentos visando à padronização de ações adotadas pelos Ministérios da Marinha e da Cultura quanto à pesquisa, exploração, remoção e demolição de coisas ou bens de valor artístico, de interesse histórico ou arqueológico afundados, submersos, encalhados e perdidos em águas sob jurisdição nacional, em terrenos de marinha e seus acrescidos e em terrenos marginais, em decorrência de sinistro, alijamento ou fortuna do mar.

\section{PROTEÇÃO}

2.1. Compete ao Ministério da Marinha a proteção de coluna ou bens de valor artístico de interesse histórico ou arqueológico afundados, submersos, encalhados e perdidos em água sob jurisdição nacional, em terrenos de marinha e seus acrescidos e em terrenos marginais, em decorrência de sinistro, alijamento ou fortuna do mar.

2.2. As coisas e bens, mencionados em 2.1, retirados sem a devida autorização, serão confiscados estando os infratores sujeitos às sanções legais. 


\section{LOCALIZAÇÃO}

3.1. As pessoas físicas ou jurídicas interessadas em realizar operações e atividades de localização de coisas ou bens afundados, submersos, encalhados e perdidos em águas sob jurisdição nacional, em terrenos de marinha e seus acrescidos e em terrenos marginais em decorrência de sinistros, alijamento ou fortuna do mar, deverão ser previamente cadastradas no Ministério da Marinha.

3.2. Caberá ao Ministério da Marinha conceder autorização para a localização de coisas ou bens afundados, submersos, encalhados e perdidos em águas sob jurisdição nacional, em terrenos de marinha e seus acrescidos e em terrenos marginais em decorrência de sinistro, alijamento ou fortuna do mar.

3.3. A pessoa física ou jurídica autorizada a efetuar as atividades mencionadas no subitem 3.2 deverá iniciá-la no prazo máximo de 30 dias a contar da data do deferimento do seu requerimento.

3.4. Até o $5^{\circ}$ dia útil de cada mês, a pessoa física ou jurídica autorizada a efetuar as atividades mencionadas no sub-item 3.2, deverá apresentar relatório das atividades referentes ao mês anterior.

3.5. Localizadas coisas ou bens, a pessoa física ou jurídica autorizada a efetuar as atividades mencionadas no sub-item 3.2, notificará ao Ministério da Marinha o achado e contratará perito arqueológico-mergulhador credenciado para avaliação dos mesmos.

3.6. Ao término dos trabalhos deverá ser apresentado ao Ministério da Marinha relatório final das atividades realizadas, no qual deverá constar o laudo técnico do perito arqueológico-mergulhador.

\section{EXPLORAÇÃO CIENTÍFICA}

4.1. À autorização para exploração científica de áreas ou locais que contenham coisas ou bens afundados, submersos, encalhados e perdidos em águas sob jurisdição nacional, em terrenos de marinha e seus acrescidos e terrenos marginais em decorrência de sinistro, alijamento ou fortuna do mar, será da competência do Ministério da Marinha, ouvido o Ministério da Cultura.

4.2. Para cada exploração científica, o Ministério da Marinha designará uma Comissão Interministerial que terá por propósito definir, dentre a totalidade do material resgatado, as peças de valor artístico, de interesse histórico ou arqueológico.

4.2.1. A Comissão Interministerial terá a seguinte constituição: 3 membros indicados pelo MinC

4.2.2. As indicações para os membros da Comissão Interministerial devem recair sobre pessoal habilitado nas áreas de arqueologia, história da arte, e outras áreas afins.

4.2.3. A Presidência da Comissão Interministerial caberá a um dos representantes do Ministério da Marinha.

4.2.4. As decisões da Comissão Interministerial serão tomadas por consenso.

4.2.5. Na hipótese de não ocorrer consenso entre os membros da Comissão Interministerial a decisão será tomada por votação.

4.2.6. Em caso de empate na votação, caberá ao Presidente da Comissão Interministerial a decisão final sobre o assunto. 
4.2.7. O material resgatado, definido pela Comissão Interministerial como de valor artístico de interesse histórico ou arqueológico, permanecerá no domínio da União, conforme o estabelecimento no Art. 20 da Lei $\mathrm{n}^{\circ}$ 7.542/86.

\section{DISPOSIÇÕES GERAIS}

5.1. O Ministério da Marinha e o Ministério da Cultura elaborarão instruções complementares, dentro das suas atribuições, sobre o assunto. RESOLUÇÃO CONAMA N ${ }^{\circ}$ 001 .

\section{RESOLUÇÃO CONAMA No 001, DE 23 DE JANEIRO DE 1986 Publicado no Diário Oficial da União de 17/02/86}

O CONSELHO NACIONAL DO MEIO AMBIENTE - IBAMA, no uso das atribuições que lhe confere o artigo 48 do Decreto $\mathrm{n}^{\circ} 88.351$, de $1^{\circ}$ de junho de 1983 , para efetivo exercício das responsabilidades que lhe são atribuídas pelo artigo 18 do mesmo Decreto, e

Considerando a necessidade de se estabelecerem as definições, as responsabilidades, os critérios básicos e as diretrizes gerais para uso e implementação da Avaliação de Impacto Ambiental como um dos instrumentos da Política Nacional do Meio Ambiente, RESOLVE:

Art. $1^{0}$ - Para efeito desta Resolução, considera-se o impacto ambiental qualquer alteração das propriedades físicas, químicas e biológicas do meio ambiente, causada por qualquer forma de matéria ou energia resultante das atividades humanas que, direta ou indiretamente, afetam:

I. a saúde, a segurança e o bem-estar da população;

II. as atividades sociais e econômicas;

III. a biota;

IV. as condições estéticas e sanitárias do meio ambiente;

V. a qualidade dos recursos ambientais.

Art. $\mathbf{2}^{\mathbf{o}}$ - Dependerá de elaboração de estudo de impacto ambiental e respectivo relatório de impacto ambiental, RIMA, a serem submetidos à aprovação do órgão estadual competente, e do IBAMA em caráter supletivo, o licenciamento de atividades modificadoras do meio, tais como:

I. $\quad$ estradas de rodagem com duas ou mais faixas de rolamento;

II. ferrovias;

III. portos e terminais de minério, petróleo e produtos químicos;

IV. aeroportos, conforme definidos pelo inciso I, do artigo 48, do Decreto-Lei ${ }^{\circ}$ 32, de 18/11/66;

V. oleodutos, gasodutos, minerodutos, troncos coletores e emissários de esgotos sanitários;

VI. linhas de transmissão de energia elétrica, acima de $230 \mathrm{Kv}$;

VII. obras hidráulicas para exploração de recursos hídricos, tais como: barragem para fins hidrelétricos, acima de 10MW, de saneamento ou de irrigação, abertura de canais 
para navegação, drenagem e irrigação, retificação de cursos d'água, aberturas de barras e embocaduras, transposição de bacias, diques;

VIII. extração de combustível fóssil (petróleo, xisto, carvão);

IX. extração de minério, inclusive os da classe II, definidas no código de Mineração;

X. aterros sanitários, processamento e destino final de resíduos tóxicos ou perigosos;

XI. usinas de geração de eletricidade, qualquer que seja a fonte de energia primária, acima de $10 \mathrm{MW}$;

XII. complexo e unidades industriais e agro-industriais (petroquímicos, siderúrgicos, cloroquímicos, destilarias de álcool, hulha, extração e cultivo de recursos hídricos);

XIII. distritos industriais e zonas estritamente industriais - ZEI;

XIV. exploração econômica de madeira ou de lenha, em áreas acima de 100 hectares ou menores, quando atingir áreas significativas em termos percentuais ou de importância do ponto de vista ambiental

XV. qualquer atividade que utilize carvão vegetal, em quantidade superior a dez toneladas por dia.

Art. $3^{\circ}$ - Dependerá de elaboração de estudo de impacto ambiental e respectivo RIMA, a serem submetidos à aprovação do IBAMA, o licenciamento de atividades que por lei seja de competência federal.

Art. $4^{\mathbf{0}}$ - Os órgãos ambientais competentes e os órgãos setoriais do SISNAMA deverão compatibilizar os processos de licenciamento com as etapas de planejamento e implantação das atividades modificadoras do meio ambiente. Respeitados os critérios e diretrizes estabelecidos por esta Resolução e tendo por base a natureza, o porte e as peculiaridades de cada atividade.

Art. $5^{\mathbf{0}}$ - O estudo de impacto ambiental, além de atender à legislação, em especial os princípios e objetivos expressos na Lei de Política Nacional do Meio Ambiente, obedecerá às seguintes diretrizes gerais:

I. contemplar todas as alternativas tecnológicas e de localização de projeto, confrontando-as com a hipótese de não execução do projeto;

II. identificar e avaliar sistematicamente os impactos ambientais gerados nas fases de implantação e operação da atividade;

III. definir os limites da área geográfica a ser direta ou indiretamente afetada pelos impactos, denominada área de influência do projeto, considerando, em todos os casos, a bacia hidrográfica na qual se localiza;

IV. considerar os planos ou programas governamentais, propostos e em implantação na área de influência do projeto, e sua compatibilidade.

Parágrafo Único - Ao determinar a execução do estudo do impacto ambiental, o órgão estadual compete, ou o IBAMA ou, quando couber, o Município, fixará as diretrizes adicionais que, pelas peculiaridades do projeto e características ambientais da área, forem julgadas necessárias, inclusive os prazos para conclusão e análise dos estudos.

Art. $6^{\mathbf{0}}$ - O estudo de impacto ambiental desenvolverá, no mínimo, as seguintes atividades técnicas:

I. diagnóstico ambiental da área de influência do projeto, completa descrição e análise dos recursos ambientais e suas interações, tal como existem, de modo a caracterizar a situação ambiental da área, antes da implantação do projeto;

a) o meio físico, o subsolo, as águas, o ar e o clima, destacando os recursos minerais, a topografia, os tipos e aptidões do solo, os corpos d'água, o regime hidrológico, as correntes marinhas, as correntes atmosféricas, 
b) o meio biológico e os ecossistemas naturais, a fauna e a flora, destacando as espécies indicadoras da qualidade ambiental, de valor científico e econômico, raras e ameaçadas de extinção e as áreas de preservação permanente,

c) o meio sócioeconômico, o uso e a ocupação do solo, os usos da água e a sócioeconomia, destacando os sítios e monumentos arqueológicos, históricos e culturais da comunidade, as relações de dependência entre a sociedade local, os recursos ambientais e a potencial utilização futura desses recursos;

II. análise dos impactos ambientais do projeto e de suas alternativas, através de identificação, previsão da magnitude e interpretação da importância dos prováveis impactos relevantes, discriminando: os impactos positivos e negativos (benéficos e adversos), diretos e indiretos, imediatos e a médio e longo prazos, temporários e permanentes; seu grau de reversibilidade; suas propriedades cumulativas e sinérgicas; a distribuição do ônus e benefícios sociais;

III. definição das medidas mitigadoras dos impactos negativos, entre elas os equipamentos de controle e sistemas de tratamento de despejos, avaliando a eficiência de cada uma delas;

IV. elaboração do programa de acompanhamento e monitoramento dos impactos positivos e negativos, indicando os fatores e parâmetros a serem considerados.

Parágrafo Único - Ao determinar a execução do estudo de impacto ambiental, o órgão estadual competente, ou o IBAMA ou, quando couber, o município fornecerá as instruções adicionais que se fizerem necessárias, pelas peculiaridades do projeto e características ambientais da área.

Art. $\mathbf{7}^{\mathbf{0}}$ - O estudo de impacto ambiental será realizado por equipe multidisciplinar habilitada, não dependente direta ou indiretamente do proponente do projeto e que será responsável tecnicamente pelos resultados apresentados.

Art. $8^{\mathbf{o}}$ - Correrão por conta do proponente do projeto todas as despesas e custos referentes à realização do estudo de impacto ambiental, tais como: coleta e aquisição dos dados e informações, trabalhos e inspeções de campo, análises de laboratório, elaboração do RIMA e fornecimento de pelo menos 5 (cinco) cópias.

Art. $9^{\circ}$ - O relatório de impacto ambiental, RIMA, refletirá as conclusões do estudo de impacto ambiental e conterá no mínimo:

I. os objetivos e justificativas do projeto, sua relação e compatibilidade com as políticas setoriais, planos e programas governamentais;

II. a descrição do projeto e suas alternativas tecnológicas e locacionais, especificando para cada um deles, nas fases de construção e operação a área de influência, as matérias primas, e mão-de-obra, as fontes de energia, os processos e técnicas operacionais, os prováveis efluentes, emissões, resíduos de energia, os empregos diretos e indiretos a serem gerados;

III. a síntese dos resultados dos estudos de diagnóstico ambiental da área de influência do projeto;

IV. a descrição dos prováveis impactos ambientais da implantação e operação da atividade, considerando o projeto, suas alternativas, os horizontes de tempo de incidência dos impactos e indicando os métodos, técnicas e critérios adotados para a sua identificação, quantificação e interpretação;

V. a caracterização da qualidade ambiental futura da área de influência, comparando as diferentes situações da adoção do projeto e suas alternativas, bem como com a hipótese de sua não realização; 
VI. a descrição do efeito esperado das medidas mitigadoras previstas em relação aos impactos negativos, mencionando aqueles que não puderam ser evitados, e o grau de alteração esperado;

VII. o programa de acompanhamento e monitoramento dos impactos;

VIII. recomendação quanto à alternativa mais favorável (conclusões e comentários de ordem geral).

Parágrafo Único - O RIMA deve ser apresentado de forma objetiva e adequada à sua compreensão. As informações devem ser traduzidas em linguagem acessível, ilustradas por mapas, cartas, quadros, gráficos e demais técnicas de comunicação visual, de modo que se possam entender as vantagens e desvantagens do projeto, bem como todas as consequiências ambientais de sua implantação.

Art. $\mathbf{1 0}^{\mathbf{0}}$ - O órgão estadual competente, ou RIMA ou, quando couber, o município, terá um prazo para se manifestar de forma conclusiva sobre o RIMA apresentado.

Parágrafo Único - O prazo a que se refere o caput deste artigo terá o seu termo inicial na data do recebimento pelo órgão estadual competente ou pela SEMA do estudo do impacto ambiental e seu respectivo RIMA.

Art. $1^{\circ}$ - Respeitando o sigilo industrial, assim solicitado e demonstrado pelo interessado, o RIMA será acessível ao público. Suas cópias permanecerão à disposição dos interessados, nos centros de documentação ou bibliotecas da SEMA e do órgão estadual de controle ambiental correspondente, inclusive o período de análise técnica.

$\S \mathbf{1}^{\mathbf{0}}$ - Os órgãos públicos que manifestaram interesse, ou tiveram relação direta com o projeto, receberão cópia do RIMA, para conhecimento e manifestação.

$\$ \mathbf{2}^{\mathbf{0}}$ - Ao determinar a execução do estudo de impacto ambiental e apresentação do RIMA, o órgão estadual competente ou IBAMA ou, qualquer couber ao município, determinará o prazo para recebimento dos comentários a serem feitos pelos órgãos públicos e demais interessados e, sempre que julgar necessário, promoverá a realização de audiência pública para informação sobre o projeto e seus impactos ambientais.

Art. $1^{\circ}$ - Esta resolução entra em vigor na data de sua publicação.

Flávio Peixoto da Silveira. 